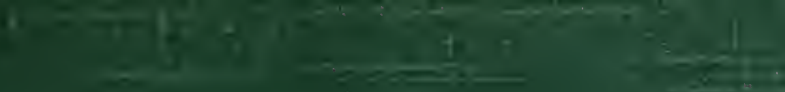

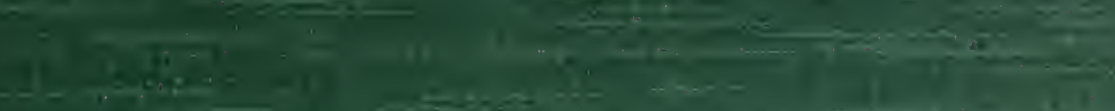

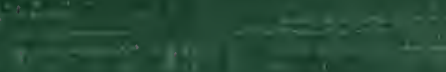

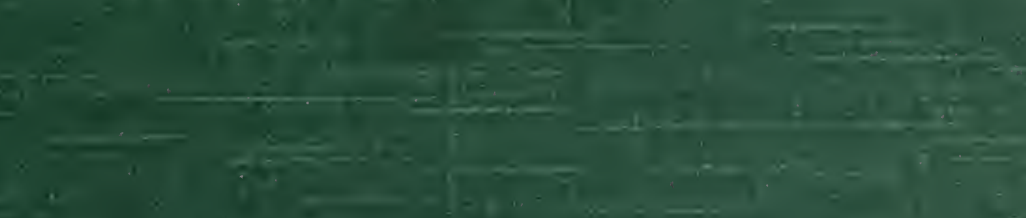

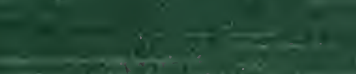

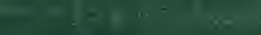

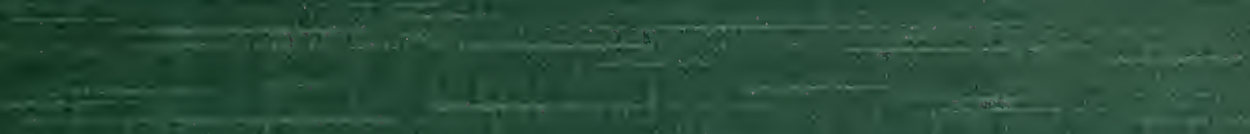

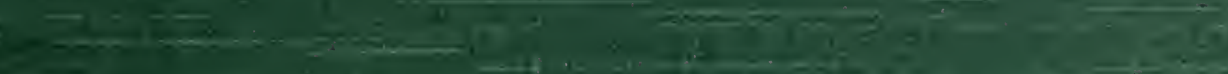

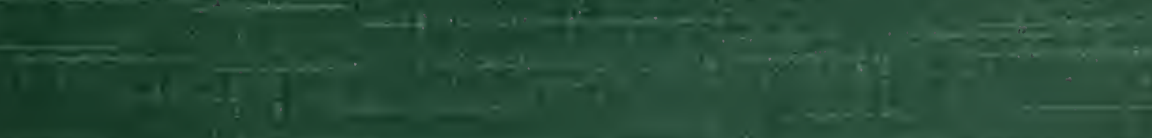

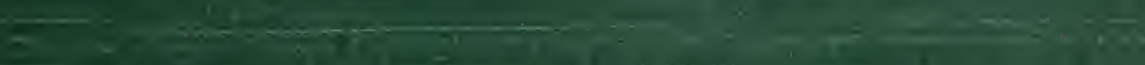

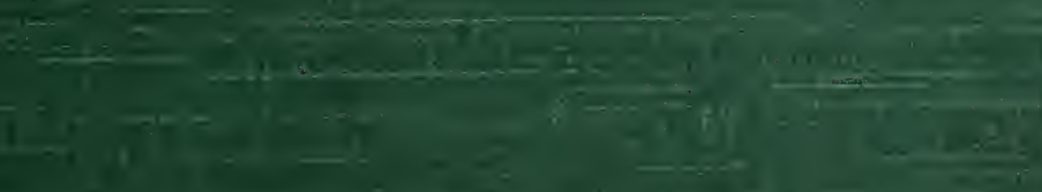

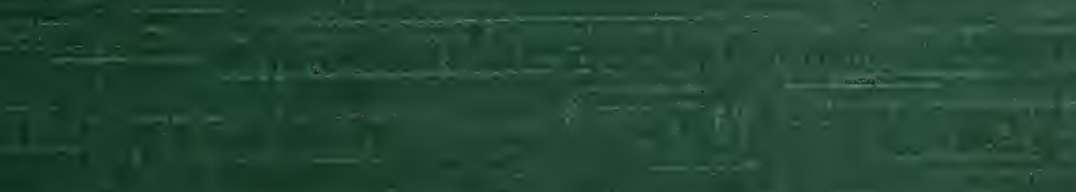

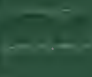

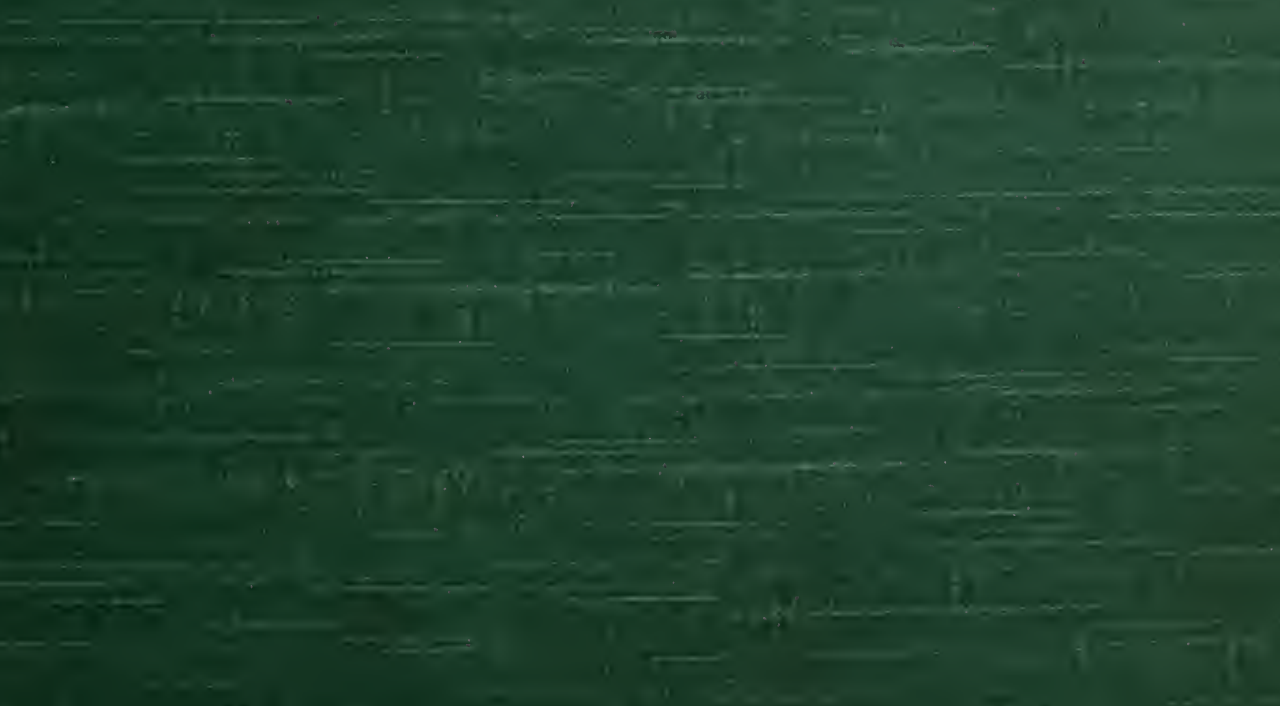

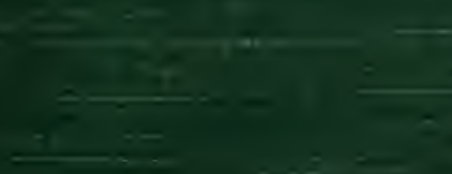

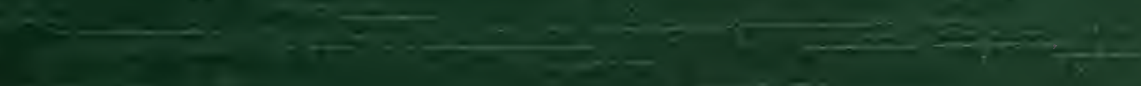

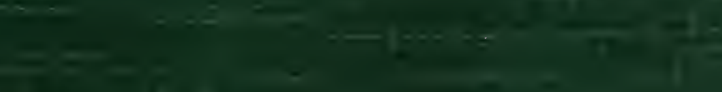




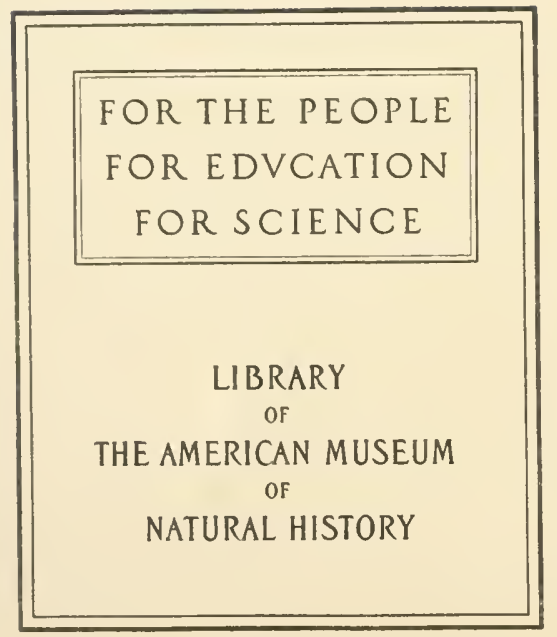




NOTES ON

THE BIRDS OF KEN'T. 




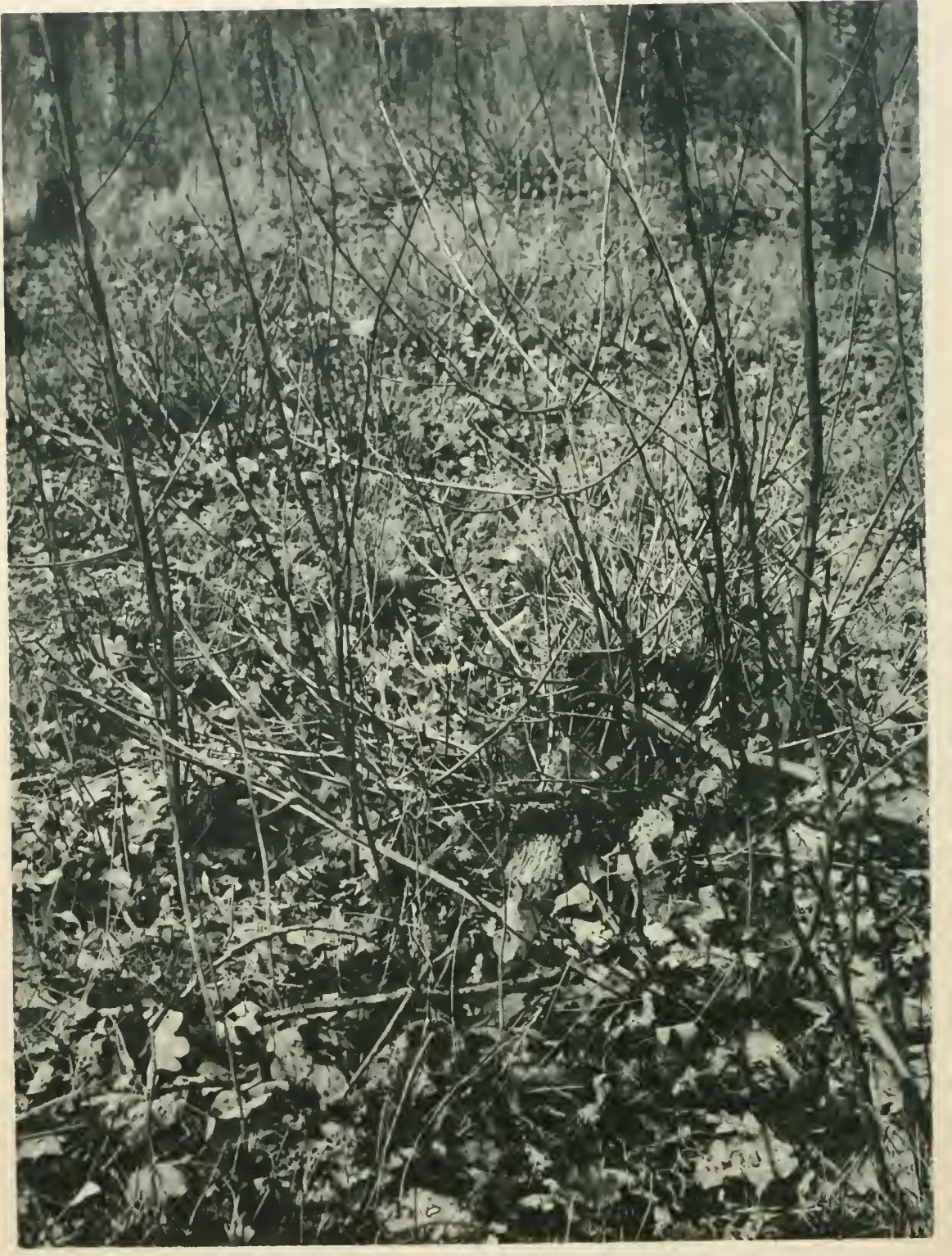

WOODCOCK ON ITS NEST. 


\section{NOTES}

ON THE

$5982(42.23)$

\section{BIRDS OF KENT}

BY

R. J. BALSTON, D.L., J.P., F.Z.S., M.B.O.U.,

REV. C. W. SHEPHERD, M.A., F.Z.S., M.B.O.U.

AND

E. BARTLETT, F.Z.S.

WITH NINE PLATES AND A MAP

\section{Lolloon}

R. H. PORTER

7, PRINCES StREET, CAVENDISH SQUARE, W. 
1980882 Dee 26

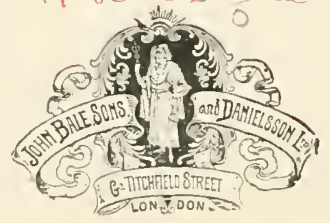




\section{PREFACE.}

THE origin of the present work is founded on the material brought together in connection with a certain area in Kent, but in that limited portion of the county it was noticed that the Avi-fauna would scarcely be of sufficient importance for even a small work like that of the Birds of Rainham, by the late Mr. W. Prentis, therefore it was carefully considered and found advisable to take in the whole of the county. It was also thought desirable to collect all the material hitherto written, and give to those who have done so much towards our knowledge of the Birds of Kent, full credit for their observations. In doing this it necessitated much time to collect the scattered information, and research into all the works inaccessible to the general reader, including numerous publications from a very early date, beginning with Linnæus's Systema Nature (1766); Latham's General Synopsis of Birds (1781-87-1801) ; Boys' Birds of Sandwich (1792); the Zoologist (1843-1906); the Rev. J. Pemberton Bartlett's notes on the Birds of Kent (1844); G. Dowler's Birds of East Kent (1889) ; Messrs. Power and IV. Prentis's Birds of Rainham (1894); J. Gould's Birds of Great Britain (1873); Yarrell's British Birds (1871-85); J. E. Harting's Hand-books (1872-1901), and many other 
Works too numerous to quote here, but reference to which will be found in the text.

The nomenclature and classification of the List of British Birds, compiled by the Committee of the British Ornithologists' Union (1883) has been maintained in the present book.

The Linnæan specific names having priority, irrespective of their having been used for generic terms, are retained, by the special desire of many eminent naturalists.

In the British Ornithologists' Union list (1883), 452 species are enumerated; 76 of these are placed in brackets as Non-British birds, leaving 376 which are considered truly British; 128 residents; 52 summer visitors; 165 occasional visitors; 31 winter visitors.

Mr. J. E. Harting, in his last Hand-Book, 1901, puts the numbers down as follows:-

130 residents; 100 periodical emigrants; 32 annual visitors; 167 being rare accidental visitors.

In Kient, up to the present time, 320 species are recognised and divided into the following order :-

(1) Residents which are to be found at all times, and breed in the county $\quad \ldots \quad \ldots \quad \ldots \quad \ldots \quad \ldots 66$

(2) Regular summer visitors which breed in the

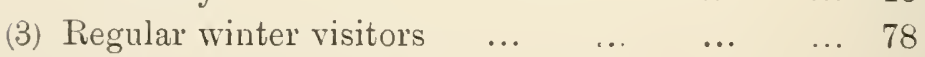

(4) Occasional visitors, which have been found more $\begin{array}{lllllll}\text { than twice } & \ldots & \ldots & \ldots & \ldots & \ldots & 35\end{array}$

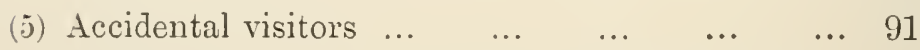

(6) Introduced a few years ago, Red-legged Part$\begin{array}{lllllllll}\text { ridge } & \ldots & \ldots & \ldots & \ldots & \ldots & \ldots & 1\end{array}$

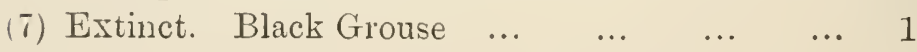


This latter bird is put under the word extinct, as it is highly improbable it will ever regain its former status.

Many of the birds, which might also come under the same word, such as the Crane, Bustards, Cream-coloured Courser, \&c., are likely to become occasional visitors, although comparatively extinct in the county.

The American Robin, Northern Mocking-bird and American Screech Owl, are included in the accidental visitors.

The following birds, although having been procured in Kent, are excluded from the Kentish birds proper, viz.: Whydah Finch, Rainham; Red-billed Whydah bird, Lydd; Crimson Weaver bird, Lydd. To retain these among the Kentish birds would be quite as consistent as retaining the Gold-vented Bulbul of Cape Colony, which Mr. Harting still adds to his "rare and accidental visitors."

The Pelican, Black Swan, Summer Duck and Virginian Colin, have been procured in Kent, but sufficient evidence of their having escaped from captivity is given, therefore these have been omitted.

It may be noted that those birds which can swim have a greater chance of reaching the coast of England and Europe, but in the case of delicate, small birds, there is no doubt that they take refuge and rest on the numerous large vessels continually traversing the Atlantic Ocean, hence their discovery on our shores.

There is one very extraordinary circumstance which deserves notice, that a very large number of the rare seedeating and other birds should have been found on the Sussex coast, and there is some suspicion that most of these birds have been introduced; none of these birds having been observed in Kent although an adjoining county. 
viii. THE BIRDS OF KENT

To all those who have assisted us with their valuable notes we are much indebted and offer our sincere thanks, especially to Captain J. D. Cameron, Mrr. F. H. Waterhouse, Mr. J. H. Allchin, the Curator of the Maidstone Museum, and his assistant, Mr. H. Elgar, and also to Mr. R. T. Filmer, for the use of his manuscript notes on the birds in the neighbourhood of Orlestone.

Kent, 1907.

Edward Bartlett. 


\section{CONTENTS.}

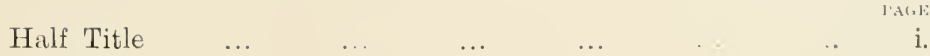

$\begin{array}{lllllll}\text { Title Page } & \ldots & \ldots & \ldots & \ldots & \ldots & \end{array}$

$\begin{array}{lllllllll}\text { Preface... } & \ldots & \ldots & \ldots & \ldots & \ldots & \ldots & \text { ฯ }\end{array}$

$\begin{array}{llllllll}\text { Contents } & \ldots & \ldots & \ldots & \ldots & \ldots & \ldots & \text { ix }\end{array}$

$\begin{array}{lllllllll}\text { Illustrations } & \ldots & \ldots & \ldots & \ldots & \ldots & \ldots & \text { xi. }\end{array}$

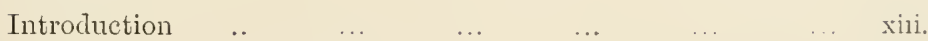

$\begin{array}{llllll}\text { Notes on the Birds of lient } & \ldots & \ldots & \ldots & \ldots & 1\end{array}$

$\begin{array}{lllllllll}\text { Index } & \ldots & \ldots & \ldots & \ldots & \ldots & \ldots & \ldots & 456\end{array}$ 



\section{ILLUSTRATIONS.}

\begin{tabular}{|c|c|c|c|c|c|c|}
\hline WoOdCOCK ON Nest & $\ldots$ & $\ldots$ & $\ldots$ & & ontisy & piece. \\
\hline White-sPotTED BLU & E-THROAT & .. & $\ldots$ & & ace $p$. & 37 \\
\hline DaRtford Warbler & $\ldots$ & $\ldots$ & $\ldots$ & $\ldots$ & ,, & 64 \\
\hline Masked SHrike & $\ldots$ & $\ldots$ & $\ldots$ & $\ldots$ & , & 137 \\
\hline Crossbill (Young) & $\cdots$ & $\ldots$ & $\ldots$ & $\ldots$ & , & 192 \\
\hline Lesser Kestrel & $\ldots$ & $\ldots$ & $\ldots$ & . & , & 304 \\
\hline Kentish Plover & $\ldots$ & ... & $\ldots$ & $\cdots$ & ," & 376 \\
\hline Avocet... & $\ldots$ & $\ldots$ & .. & $\ldots$ & ," & 388 \\
\hline Sandwich Tern & $\ldots$ & $\ldots$ & $\ldots$ & $\ldots$ & , & 426 \\
\hline MaP of Kent & .. & $\ldots$ & $\ldots$ & En & of $V$ & ume. \\
\hline
\end{tabular}





\section{INTRODUCTION.}

MaNr counties have had the history of their bird-life written, but Fent is not among them, and when we consider the county of Kient, its size, long coast line, woodlands, valleys and waterways, and nearness to the Continent of Europe, it is surprising that no such history has yet appeared. Fent is essentially a maritime county, its northern boundary the River Thames and the North Sea, east the North Sea and the Straits of Dover, and on the south it is bordered by the English Channel. Some 140 miles of its circumference is thus lapped by tidal waters. In bygone years, shore-birds and water-fowl of every description, no doubt, frequented this long coast line in great numbers, but it is not so now. From Greenwich to Gravesend the river banks are lighted by gas lamps, and from Herne Bay to Hythe, with the exception of the Sandwich Flats, the coast is given up to the tripper and the jerry builder, and gunners prowl daily along it shooting or scaring away every bird that approaches; still there are a few quiet places left where some of the old frequenters may yet be met with, especially in the estuary of the Thames, Medway, Sandwich Flats, and Romney Marsh. To understand the natural features of the county a slight description of its geological formation is necessary. The great feature of the county is the chalk; it extends from the Surrey border to the Dover cliffs, and covers nearly the whole of 
xiv.

the northern portion of the county ; its southern escarpment forms the fine range of hills called the North Downs, which in some places reach an elevation of from 700 to 800 feet, and are conspicuous throughout the greater part of the county. The crest of these hills is in great part covered with woods, and from it the land slopes down gradually to the valley of the Thames some eight or nine miles distant, where the chalk dips under the London clay. The whole of the higher part of this platean is very thinly inhabited, and many narrow deep valleys run down in a northerly direction from the crest of the Downs, having their sides and tops covered with woods wherein the beech tree and the yew tree flourish. In these wild, quiet, undulating, undisturbed regions, many summer migrants find a pleasant home, and the Hawk and the Jay live longer lives than in many other places.

At the foot of the North Downs lies a narrow belt of stiff clay called the Gault; this is chiefly grassland; further south still there is a belt of sandy limestone called the Folkestone Beds; these sands run from Folkestone through the county, and with the Gault form the great valley which is bounded on the north by the chalk downs and on the south by the Kientish Rag, or Hythe Beds of the Lower Greensand. These Kentish Rag hills form an elevated plateau and run through the middle of the county from west to east almost parallel to the north Downs. They are a very noticeable feature in Kentish scenery. Much of the most pleasing scenery and most beautiful views are to be found in this district, the range varies in width and is much wider in the middle of the county than at either end; it is broken and uneven and many small streams come from it; on its sides grow the 
best of hops and the best of orchards, there are also large tracts of woodland and common land on it. It seems that birds of all descriptions could find a home to their liking upon it. In this district, Hawfinches and Bullfinches have become very plentiful, and of late years the latter have become a perfect plague to the fruit growers. This range of hills finishes abruptly with a sharp fall to the low-lying Weald. The Weald is a bed of heavy clay, covering a tract of country four or five miles in width, and runs through the county from Edenbridge to Romney Marsh; it is a wet country, and after heavy rains is much flooded; though wholly a clay deposit in some places patches of limestone are found on it, the stone called Bethersden marble being an instance of this. Most of the Kentish rivers come from the Weald clay. To the south of the Weald rise the hills of the Hastings sands. These sands form the southern boundary of the county and cover a tract from Cowden to Rye, on the border of Romney Marsh; they form a sandy undulating district with patches of clay and ironstone, with many dales and hills and little streams.

From this sketchy account of the geology of the county it is possible to form some idea of its general features. There is the great chalk range to the north some eight or nine miles in width, then on the south of the chalk the wide valley of the Gault and the Folkestone sands, having on its southern side the Kentish Rag hills; these hills form as it were the backbone of the county, having on their north the valley of the Gault, and on the south side the valley of the Weald; these two great valleys run nearly the whole length of the county from west to east, with the Kentish Rag between them. There are two districts not yet alluded to which are in- 
teresting ornithologically: first, the tertiary deposits; these consists of the Woolwich beds and the London clay. The Woolwich beds cover a considerable tract of country in the north-west of the county from Deptford to Plumstead, and from Croydon to the Crays; these deposits consist of a sandy, gravelly soil, and form an undulating, well-timbered country, which before it was turned into a suburban district was, no doubt, a very pleasing country. It has been said that the county obtained its name of the Garden of England from the charm and fruitfulness of this district, but now it is all changed and can be pleasing only to the lovers of the villaesque. Still, birds do not seem to have forsaken it. A recent writer in a daily paper states that during the last few years he has noted no less than seventy-seven species in this thickly-populated part of the county, mentioning among them a Nightingale singing at Plumstead. Birds we know from London (Wood Pigeons and Gulls), if not persecuted, do not mind bricks and mortar, and in the large gardens and enclosed grounds and paddocks which surround the large houses, numerous throughout the district, they would find many congenial retreats.

It was here, on Bexley Heath, that the Dartford Warbler was first observed in 1773. The London clay is the chief tertiary deposit in the county; it lies in patches by the river side from Plumstead to Gravesend, but below that town it covers a wide tract, including the Hundred of Hoo and the Isles of Grain and Sheppey. This marshy, low-lying tract between the two rivers, the Thames and Medway, is frequented by many wild fowl and shore birds, many making it their summer resort, and among them there is a colony of Little Terns. 
Not so many years ago large flocks of Oxbirds and Godwits were to be seen above Rochester Bridge feeding on the mud banks at low water, but now the Medway is given up to the cement maker, and there is no longer room for the Oxbird. On the southern side of the Swale the London clay is found in patches large and small as far as Faversham, where it swells ont and covers a large tract of country. From Faversham to the Lueculvers, and on the south by way of the Blean Woods to Canterbury, and over the valley of the Stour to Sandwich, all this low-lying country, thinly inhabited, intersected by ditches and the winding Stour; is still frequented by many birds, especially abont the month of the Stour. 'The boom of the Bittern might perhaps have been heard there again this year, as it is reported that two of them have been shot there quite lately. 'T'he Sandwich Flats are a favonite resort of Curlews, Plovers and Sandpipers. 'This mass of London clay lies over the chalk, but the chalk crops up again in the Isle of Thanet and extends the chalk cliffs along the shore from Ramsgate to the Reculvers. These white walis of old England afford nesting places for a variety of birds, Jackdars and Starlings especially delighting in them; a few pairs of Guillemots may be met with round the South Foreland, and on the Dover cliffs and St. Margaret's Bay two or three pairs of Peregrines are said to breed yearly, though more often than not it is to be feared their nests are robbed.

'l'he Romney Marsh is a district apart, separated from the rest of the county by the Military Canal, and is altogether diverse in its character and appearance; it is ten miles wide from north to south and half as much agrain from west to east, and is a very low-lying region, 
xviii.

which would probably be covered by the sea at high water were it not for the vast mass of shingle beach thrown up by the sea, forming a protective breakwater. Thousands of acres of this beach are without a blade of grass, and thousands more with just the beginnings of vegetation visible; this beach increases year by year, and on it many birds breed. Here may be found the Stone Curlew, the Ringed Plover and the Kentish Plover. Here also are colonies of the Common and Little Tern, and Black-headed Gull. Owing to the great difficulty of walking over the vast extent of loose shingle, the nests of these birds are not often robbed, though in all cases where eggs are valuable there is sure to be some persevering robber who manages to find them.

The whole of the Marsh is much cut and intersected by sewers, as the Marsh drains are called, which are lined with reeds and rushes, and form retreats for Reed and Sedge Warblers; near the sea where the ditches are wider and there are swampy places, Redshanks and Wagtails make their nests. At one time, too, there used to be a colony of Sandwich Terns, but they are seldom seen now.

Not much is known about the arrival of summer migrants on the Rentish coast. From the Bulletin of the British Ornithologists' Club, on the immigration of summer residents it appears that, as far as present observations go, the chief routes taken by the birds lie further to the west, and that the greatest part arrive on the coasts between Devonshire and Hampshire. It may be that the passage over the water to the Kentish coast being so very much shorter, the birds do not alight on reaching land, but pass on into Essex or Suffolk, and so no great quantities are observed at any one time 
in Kent, but emigrants in autumn have been observed in great numbers on the border's of the Marsh, especially Blackbirds and Willow Warblers. Probably those that go that way would return by the same route the next spring.

The chief river in the county is the Medway, which, rising in Sussex, flows by Tonbridge to Maidstone, and so by Rochester to the Estuary of the Thames. 'The Beult flowing through the WVeald joins the Medway at Yalding, and the Theyse coming from the south also joins it at the same place. The Stour rising near Lenham flows by Ashford, and keeping a north-easterly course passes by Canterbury and enters the sea at Sandwich. The Darenth rising near Sevenoaks flows north to the Thames. It may be noticed that all these river's flow in a northerly direction and make their way through the Kentish Rag and North Down ranges, which seems strange; but geologists tell us that once upon a time the whole county was more or less upon a level, with a gentle dip towards the basin of the Thames, the IVeald being the highest ground, and that these rivers rising in the Wealden clay naturally flowed towards the Thames, and then as ages and ages rolled on, in spite of upheavals and depressions, the rivers held their course and cut their way through all obstructions.

These few observations of the features of the county of Kent, are the observations of a casual observer as he passes along unburdened by scientific knowledge; what a similar individual may observe in the days of another generation will probably be very different; he may see vast portions of fair country disfigured by coal mines, and the whole of the Kentish coasts fringed with bathing machines, as even Dungeness has already broken out in bungalows. 



\title{
THE BIRDS OF KENT.
}

\section{Order PASSERES.}

Family TURDIDÆ.

Genus TURDUS, Linnæus.

\author{
THRUSHES. \\ SONG-BIRDS. \\ MISSEL-THRUSH.
}

Turdus viscivorus, Linnæus. Syst. Nat., i.,

$$
\text { p. } 291 \text { (1766). }
$$

Missel-Thrush, Mistletoe-Thrush, Misseltoe-

Thrush and Stormeock.

THis large and conspicuous Thrush is by no means so abundant in any part of the county as the Song-Thrush, and although plentiful, its obscure grey colouring somewhat protects it from the ordinary observer, but its size when seen always attracts attention. It is most noticeable during the autumn and winter, when the trees are destitute of foliage, then the Missel-Thrush may be observed in large numbers. No doubt a great many go south and leave the county; for towards the end of October they have greatly diminished in numbers, but increase again towards the end of March and the early part of April. The Missel-Thrush bas been heard singing as early as February 26. Although a wild and shy bird 
it usually keeps near the home of man, especially in the breeding season.

It is in orchards and gardens and frequented places that the Missel-Thrush prefers to nest and rear its young. On May 8 a Missel-Thrushes' nest was found placed on an old beech stump, by the side of a wood; it was about 4 feet from the ground and so carefully concealed among the old short stumps of the linotted trunk, that it appeared to be part of the old stump itself. It was composed of roots and bents and coarse grass, and lined with finer material, with a few pieces of green moss stuck in on the outside (no sheep's wool), and contained callow young; five days afterwards they mere fully feathered, and on the 17th they were gone.

Another nest, not far from a farmhouse, was placed in a large whitethorn bush, about 9 feet from the ground, and was composed for the most part of sheep's wool and roots, in a most careless and rough manner; another was placed in a thorn-bush in a thick hedge about 5 feet from the ground, of a very neat and compact construction, principally composed of very fine roots and grass. A nest which was placed in the fork of a hazel-nut tree, about 9 feet from the ground, was nearly covered on the outside with green moss. The nests usually contain four eggs, which vary both in size and colour.

It is during the breeding season that the Missel-Thrush appears to be very scarce, but we can understand why this is, their obscure colouring and shyness, and the protective foliage amongst which they hide, save them from observation. They glide from their nest and rery quickly disappear. But the strange part of it is, as soon as the young are able to fly they all disappear from the orchards, gardens and lanes, and betake themselves to the woods. 
You may walk miles round the district in which you found the nests without seeing a Missel-Thrush, or perhaps only one; but they appear again in the open fields towards autumn.

Throughout the county the bird or its nest is to be found. From Lydd throughout Romney Marsh, generally about the old farms; along the Royal Military Canal from Warehorn to Lympne. It breeds in all parts of the county and is abundant in North and West Kent.

Mr. Boys includes it in his Birds of Sandwich, 1792. In 1814 the Rev. J. Pemberton Bartlett states that the Missel-Thrush is common in Kent. Among the Birds Observed at Rainham by Mr. IV. H. Power in 1865, he says: "I noticed the Missel-Thrushes collecting in flocks about the end of July, at which time they usually become shy and difficult of approach; they breed in the orchards, but each pair appears to consider the ground for a certain distance around the nest private property, driving away with the greatest fury any unfortunate Magpie, Crow, Jay, \&c., that presumes to invade their territory."

This species was found in the Higham district, according to the Rev. C. H. Fielding. Mr. G. Dowker includes it in the Stourmouth district. Again the Rev. C. H. Fielding says it is a common resident in Kent, and adds it to his Birds of the Malling Valley. In the Rainham district, Mr. W. Prentis tells us that "a few mild days in February the Missel-Thrush begins to enliven us with its song, being the first of the Thrushes to remind us of the time of year; builds the latter end of March, making its nest and laying its eggs in either an apple or pear tree in our orchards."

Captain Boyd Alexander mentions the "Missel-Thrush" as found in the Cranbrook district. 
During short visits to the beach at Dungeness by Mr. Thomas Hepburn in 1900, he says: “On May 10 I found a nest of Turdus viscivorus in one of the clumps of elder and holly bushes which are a feature of this stretch of beach. The nest was in the fork of an elder bush not more than three feet above the ground. The outside of the nest was made almost entirely of sheep's wool, with a few sticks entangled in it, and was neatly lined with fine grass. It contained four young birds about a week old. July 16 to 21 , noticed considerable numbers of these birds on the grass-lands and meadows which join the beach. They seemed to be mostly young birds."

In the observations on birds in the neighbourhood of New Romney and Littlestone-on-Sea in 1902, Mr. L. F. M. Elms writes: May 19, "came across three Missel-Thrushes' nests, all built in most conspicuous positions and easy of access. They were all empty, and, as there were no fragments of egg-shells in any of them, it appeared they must have been pilfered of their contents. One nest in particular had an extraordinary amount of sheep's wool in its composition-in fact, the builder evidently was completely nouplussed as how to properly use so large a piece, with the consequence that half of it was blowing about like a small flag-a very advertisement of the nest's whereabouts."

Mr. R. T. Filner tells us that the Missel-Thrush is "common" about Orlestone, and is plentiful all over the adjoining districts. Captain J. D. Cameron also states that the Missel-Thrush is found in the district of Bethersden. 


\section{SONG-THRUSH.}

Turdus musicus, Limnæus. S.N., i., p. 2922 (1766). Throstle, Mavis, Grey-Bird.

'This bird is abundant throughout the county; you cannot walk along a lane, across a field, through a park, or enter a large garden without noticing a Thrush at all times in the year. The young birds, of course, are more conspicuous in all direcions after they leave the nest and when they are just able to fly about, and again in autumn when they resort to the homestead for food and shelter.

This Thrush becomes extremely tame and sociable, and wild bred birds, reared close to the house, have been known to the inbabitants to approach within a few feet of them without flight or fear.

In the spring, when the birds pair and have selected a position for the nest, the male bird finds a perch on the top of the nearest tall tree, and there you may find him regularly, morning and evening, and no doubt during the intervals he is busy with the female constructing the nest, which is sure to be not far off. These nests, unfortunately, are so conspicuous in early spring that it is a wonder how so many escape the bird's-nester. So trustful are the birds that they build their nests in low stunted bushes or hedgerows along the roadsides, where you can actually look in on the eggs, generally 3 to 4 feet above the ground.

The birds themselves will scarcely move, even when the nest is closely approached. The eggs, being blue, also attract immediate attention.

The nest of this species is nearly always lined with 
a mud mixture, but from the following account by Mr. H. F. Witherby, of Blackheath, it appears that some nests are made without mud :-

" On April 20 (1893) I found three nests of the SongThrush, Turdus musicus, two of which contained four eggs and the third three eggs. None of these nests had any trace of mud in them. One of them, which I have kept, is made entirely of grass, the lining of the inside being a little finer in texture than the outside. The inside of the nest is left in a very rough state, and the grass is not woven together at all neatly, but looks as though the bird had intended to line it in the usual way, but was not able to obtain any. No doubt the reason for this is the remarkably dry season. I might say that these nests were found on some downs, while others found near a river within a mile of the downs were formed in the usual manner."

The colour of the egg of the Thrush is a beautiful pale blue, more or less spotted, and streaked with black and dark brown. Mr. A. G. Butler, who has paid great attention to British birds' eggs, gives the following notes of several found in Kent: Eggs "normal form, Sittingbourne, May 24 ; Rodmersham, May 27 ; Barming, June 8. Var. $a$, streaked at large end, like a bunting's egg, with brown, Rodmersham, May 23; var. b, all the spots extremely small, Murston, May 26 ; var. $c$, much elongated, Sittingbourne, May 27; var. $d$, the black spots at the small end, Barming, June 7 ; var. $e$, all the spots pale brown, not rounded, Barming, June 8." The eggs vary much in size and markings, even in the same nest. On May 18 a nest was found containing four beautiful young Thrushes, with fine bold black eyes, nearly able to $\mathrm{fly}$; this nest was placed in a whitethorn, 
by the side of a path through a small wood; the nest was on a line with the face of the passer-by, and it was almost impossible to pass it without seeing the young ones. Another nest containing five young birds just able to fly (May 25) was placed in an old furze-bush about 4 feet from the ground, and formed a very pretty picture, with the fine marking of the breasts and bright eyes of the young birds.

In Boys' Birds of Sandwich, 1792, this bird appears under the name of "Throstle." In 1844 the Rev. J. Pemberton Bartlett says these "heralds of approaching spring are abundant in Kent." Mr. C. Collingwood, in his notes on the Birds of the Neighbourhood of Blackheath, states that the Thrush commences to sing on February 5, and recommenced to sing on October 19. The Song-Thrush may be heard during warm days throughout the winter. WVe gather from the MS. notes left by Mr. H. Lamb, that the Thrush is very numerous and breeds in the Maidstone district, and sings nearly all the winter in the town gardens during mild weather. In the autumn of 1879 he saw this bird eating yew berries in Ulcombe churchyard. The Rev. C. H. Fielding says it is found in the Higham district, and resident all the year in Kent, and that it is a resident all the year in the Malling valley. It is distributed over the whole of Romney Marsh down to Dungeness. According to Mr. WValter Prentis, of Rainham, "The SongThrush begins to warble forth its charming song at the beginning of February, and enlivens us at bright intervals throughout the month." It is also plentiful, Captain J. D. Cameron tells us, in the Bethersden district. Mr. T. Hepburn found it "nesting in the patches on the beach at Dungeness." In the Orlestone district 
Mr. R. T. Filmer says it is "common and breeds there." In South, WVest and North Kent it appears to be just as abundant as in East lient.

Writing abont the birds of the Cranbrook district, Captain Boyd Alexander says: "The severe drought (1896) has at length abated; while it lasted things looked distressed. The dark foliage of copse and hedgerow stood out in bold relief against the brown of the parched-up pasture-lands, cropped close, and in places to the very roots, by grazing sheep and cattle. In bird-life the scarcity of food became also felt. It was quite a painful sight to witness Thrushes and Blackibirds on the parchedup fields, engaged in their spasmodic ramblings after worms which they could not get. Premature migration became general with Missel- and Song-Thrushes, and also with Blackbirds, when the currants and raspberries in our gardens no longer afforded them subsistence."

\section{REDIVING.}

\section{Turdus iliacus, Linnæus. S.N., i., p. 292 (1766).}

It is well known among naturalists that Redwings are only winter visitors to this country.

The following notes respecting its arrival in this county have been given. Mr. G. WV. Hulke, in his list of the arrivals of winter visitor's at Deal, gives October 14. In the Rainham marshes Mr. F. D. Power says: "First seen on October 9. On the morning of the 21 st a considerable migration of these birds took place in a south-westerly direction."

Mr. W. Prentis writes: "They come in autumn, the latter end of October, in small numbers. Should the 
winter be severe, they suffer equally with the songThrush."

Redwings were first observed in the Mersham district on November 24, and they increased in numbers in January, and remained in the woodsides about Bilsington and Ruckinge up to the end of March, and appeared then to be going north. It is also mentioned in the "Higham district" and the "Malling valley" by the Rev. C. H. Fielding. Mr. H. Lamb says: "It is common in the Maidstone district," and he saw a flock of about a dozen in December, 1878, in the Loose valley, and they seem especially fond, he says, "of poling about amongst dead leaves and in the open fields in mild weather, and I have seen it near Maidstone as late as the first week in April."

Captain J. D. Cameron tells us that it visits the Bethersden district. In the Birds of East licnt, Mr. G. Dowker states that the Redwing is "common," and he says, "I have known of its breeding here," without giving any reference or particulars on the subject. 'The Rev. G. Pemberton Bartlett remarks that "Redwings generally arrive a short time before the Fieldfares in Kent, but depart abont the same time." According to Lord Clifton, "Redwings, in 1867-68, were tolerably abundant at Cobham, Tient." It is included in Boys' Birds of Sandwich, 179:.

In the Orlestone and surrounding neighbourhood Mr. R. T. Filmer states "that it is a common winter visitant." Some specimens in the Maidstone Museum were shot at Boxley, one of which is a pale, buff-coloured bird. One that was picked up dead under the telegraph wires, close to Ham Street, Kent, by Mr. R. G. Rogers, on January 22, 1906, had no doubt struck the wires. In 
the Bulletin of the B.O.C., vol. xvii., it is reported that the Redwing was taken on April 28, at Long Sand Lighthouse, Kent. Referring to Mr. G. Dowker's note above, respecting the breeding of Redwings in Kent, the only confirmation of this that can be found is given by Mr. A. Kennard in the Zoologist, 1886. He says: "A nest of this bird has been found at Cranbrook, Kent. Of the identity of the species I am quite sure, for the bird was killed on the rest, and proved to be a Redwing." On looking over the Rev. C. Swainson's book of Provincial Names and Folk Lore of British Birds, the following curious story may be extracted :-

"A rushing, rustling sound is heard in the English Channel on the dark, still nights in winter, and is called the 'herring spear,' or 'herring piece,' by the fishermen of Dover and Folkestone. 'I'his is caused by the flight of those pretty little birds, the Redwings, as they cross the Channel on their way to warmer legions. The fishermen listen to the sound with awe, yet regard it, on the whole, as an omen of good success with their nets"-quoting Dr. Buckland's Curiosities of Natural History, Series II., 285-6.

\section{FIELDFARE.}

Turdus pilaris, Linnæus. S.N., i., p. 291 (1766). Felt, and Pigeon-Fieldfare.

The Fieldfare is a regular winter visitor to this county; the numbers vary according to the severity of the seasons. Some years they appear in large flocks, and scatter over the more open country, especially along the lanes and fields that are largely surrounded by haw- 
thorn bushes, the berries of which form their principal food, and it is only in very hard and trying weather that they become tame and easy of approach; should the winter remain mild and open, they are wild and difficult to get at, on account of their keeping to the highest trees in the vicinity of the food. They are the wildest and most wary birds that visit this country, and must be driven by very severe weather to come near or approach the habitation of man, and their wild, rough, rattling alarm-notes soon give notice to all other birds that danger is at hand.

In Boys' Birds of Sandwich, 1792, the Fieldfare is included among the birds. According to the Rev. J. Pemberton Bartlett, who wrote in 1844, it was "very abundant through the winter. 'I'hey arrive in Kent about the middle of October, and take their departure about the end of April. Stragglers are occasionally seen early in May."

Mr. G. Dowker, in his Birds of East Kent, states that it visits East Kent in large flocks in winter. In the Maidstone district, $\mathrm{Mr}$. H. Lamb says, "It is common in winter. In hard weather this handsome bird may often be seen almost in the town, on holly, yew and hawthorn trees, feeding on the berries. I saw several flocks of birds on January 11, 1879, pass over Maidstone, principally Fieldfares." In the Higham district and in the Malling valley, the Rev. C. H. Fielding says it is "among onr winter visitors." Writing on the immigration of Fieldfares in the Zoologist, 1887, Mr. W. Prentis, of Rainham, says: "On November 8 we were visited by numerous flocks of Fieldfares, all flying in the same direction, from east to west, the flights continuous and following each other at short intervals. They did not deviate from their 
course in the least, but each flock followed in the direction of the one before it. They flew low, just topping the hedges and woods; a few in the dusk of evening struck against the telegraph wires on our railway; five were picked up and brought to me in the evening. I observed a similar occurrence, in vastly superior numbers, in the autumn of 1878 , just previous to the two following severe winters, since which time Fieldfares about here have been scarce. A cream-coloured variety was shot December, 1878." Among the birds of Rainhan given by Mr. F. D. Power in 1869 is the Fieldfare, and in his notes, "None were observed until October 20, and not many arrived by the end of the month. Not a numerous species here at any time." The date of the arrival of the Fieldfare at Deal is given by $\mathrm{Mr}$. G. W. Hulke as "October 21." " Last year (1848) I was several times deceived, taking small flocks of Missel-Thrushes for early Fieldfares; but was soon convinced to the contrary. This year (1849) Fieldfares and Redwings were very plentiful on October 21 , and in order to satisfy myself as to the reality, I shot specimens of them both."

Writing from Cobham in Kent in 1868, Lord Clifton says: "Fieldfares have been very scarce, and I never saw more than two or three at a time. Last year (1867) Fieldfares were very abundant, large numbers appearing on January 3." Mr. G. Young says: "Although during the past winter (1883-4) I was constantly in different parts of the country, including Fient, I never saw a single specimen of the Fieldfare or Redwing.

Fieldfares were first observed this year (1905-6) on November 16, near Bilsington, and on the 24th on the hills near Mersham, and also on the 27th about the marshes below Bilsington, and they remained in that 
district up to January 23 and 24. Mr. R. T. Filmer says that it is not "as common as it used to be" in the Orlestone district. One was shot out of a large flock close to Boxley Abbey, March 6, 1868. It was found in flocks at Horton Green, on Narch 19, 1902, which were the last seen in that district, and the last obtained in the Orlestone district this year (1906) was on February 4 and April 4. It is also included in the birds of Bethersden by Captain J. D. Cameron (1906).

In the Zoologist, 1864, Мr. J. A. Clarke says: "Мy friend, Mr. R. MI. Presland, possesses a Fieldfare, which he shot at Gravesend on July 3, 186t. Is it not very late for this bird of passage? He sent it to me to preserve, and on opening the bird I found three eggs formed, about the size of a horse-bean."

The reference respecting its breeding in Kent is made on the authority of Morris in his History of British Birds, vol. iii., p. 33. He says: "A nest has been found, it is related, in Kent." As no other particulars are forthcoming regarding this short note, we have come to the conclusion that the breeding of the Fieldfare in Ient is a mistake.

\section{BLACKBIRD.}

T'urdus merula, Linnæus. S.N., i., p. 295 (1766).

Towards October the Blackbirds begin to collect in large numbers, especially under the hills, and in the large thick hedges along the winding roads which intersect the whole of Romney Marsh. On October 10 numbers of these birds were observed massing in all directions along the lanes from Ham Street, Ruckinge, Bilsington, New- 
church, Snave and Ivychurch. October 16 was a brilliant, warm, sumny moruing, and the Blackbirds were still there in great numbers, in sheltered lanes, sunning themselves, preparatory to leaving for the south. On visiting these places again on the 25th and 26th, the majority of these birds had disappeared, leaving only a straggler here and there. Among the hundreds observed while they were collecting, it was noticed that although the males had assumed the black plumage, very few had yellow bills, showing that these batches were composed of young birds of the year. The few old males with bright yellow bills which were among them were perhaps their leaders or guides in their migration. In the spring no batches were observed coming back, although the numbers of individuals and pairs spread over the same district had largely increased, especially in the Orlestone, Warehorne, Kingsnorth, and Aldington districts. Mr. R. 'T. Filmer says it was rery common about Orlestone and the neighbourhood.

The Blackbird is included in Boys' Birds of Sandwich, 1792. The Rev. G. Pemberton Bartlett in his Omithology of Kent (Zool., 1844), says it is "abumdant." In his Birds Observed at Rainham, 1865, Mr. WV. H. Power writes: "Blackbirds and Thrushes appear very fond of mulberries; a tree in the garden was continually under contribution. I have seen a Blaclibird with his head, throat and breast thoroughly stained with the juice."

Mr. H. Lamb says this is a "common bird about Maidstone, coming about the houses in winter and retiring to the hedges and woods in the spring, where it breeds." In the Bethersden district, according to Captain J. D. Cameron, it is resident. Mrr. IV. Prentis, in his 
Birds of Rainham, says the "Blackbird frequents our gardens all the year round." In the districts of Higham and Malling valley the Rev. C. H. Fielding states it is resident. In the Bircls of East Kent Mr. G. Dowker places it among the "common residents," and gives also the following references to localities: Nonington, IV. O. Hammond; Dover, C. Gordon; Elmstone, Rev. WV. Baldock Delmar; Walmer, Rev. B. Austen ; Folkestone, H. Ullyet; Dover, Plomley Collection.

$\mathrm{Mr}$. WV. O. Hammond, of Wingham, gives instances of birds flying against window-panes, and includes the Blackbird and Thrush. Many of these birds are killed by the force with which they come in contact with the glass.

In the Zoologist, 1895, Mr. A. G. Butler, of Beckenham, mentions a "supposed hybrid between the Blackbird and Thrush caught in his garden." TVe have not observed a specimen of this kind yet.

The nests of the Blackbird are abundant enough in the spring and early summer, and they are placed in the most exposed places. On April 6, in the bottom of Burnt Oak Wood, near Orlestone, Kent, a nest was found on the ground with three eggs, under a small bramble. Some nests are 4 or 5 feet from the ground, but generally about 3 feet. Mr. T. Hepburn, in his notes on the birds of the beach at Dungeness, says: "This bird was also nesting in the patches of bushes on the beach." Blackbirds are very often pied in various ways and sometimes are pure white. Lord Clifton records a case in which a "brood of white Blackbirds, four or five in number, was found at Cobham, Kent, besides many pied varieties." A white one was seen on September 15, at Bromley Green, near Ashford. At Dover a Blackbird's nest with two eggs was found on February 5, 1906. 
While bird's-nesting in Kent in 1875, Mr. A. G. Butler gives the following notes respecting those and the eggs he found: "Todmersham, May 27 ; Sittingbourne, May 28; Bredgar, June 1 ; Barming, June 7 , var. $b$, subcylindrical, green, spotted with ferruginous; Sittingbourne, May 27, var. 6, like some varieties of Missel-Thrush, greyish-green, prettily mottled with ferruginous ; Sittingbourne, May 24, var. $c$, a brown zone at the large end; Bobbing, June 11." He also figures a white egg in British Birls" Eggs, pl. xxxvii. It "was one of a pair" taken from an ordinary nest at Wateringbury, near Maidstone."

Among the Birds in the Neighbourhood of Blachicath, Mr. C. Collingrood states that the "Blackbirds commenced their song on March 5, 1854, and recommenced their song on August 4."

\section{RING-OUZEL.}

Turdus torquatus, Linnæus. S.N., i. p., 296 (1766).

The Ring-Ouzel is far from being plentiful in the county of lient. It may be that it is overlooked, on account of its close resemblance to the Blackbird, and there is no doubt that it keeps more to the higher hills and elevated commons than to the low-lying districts.

On Norember 18, 1905, Mr. E. Bartlett, when returning from a walk round, throngh Ham Street, caught sight of a Ring-Onzel in a field close to the Court Lodge at Ruckinge, which is on the slopes overlooking Romney Marsh. The bird turned round and stood looking at him, therefore he had plenty of time to identify it. There was a number of Blackbirds and 
Thrushes not far from it. This is the only one observed in 1905-6.

Latham (1783) mentions that, "Now and then one is met with in the more southern parts. Such an illfated straggler was shot near Dartford." In the Topography of Maidstone, 1839, it states that "a Ring-Ouzel was shot at Detling about two years since." In his Ornithology of Kent the Rev. J. Pemberton Bartlett says, "Not uncommon in spring and autumn." Morris says, "It is observed in spring and autumn while on its migration in Kent." There are specimens in the Canterbury Museum obtained in Kent; one was shot on the Boxley Hills about 1865; and a male and femalein the Maidstone Nuseum, procured by Mr. G. Simmons in Kent. Another, in the same institution, was shot at Boxley in Kent on May 2, 1884 by Mr. W. Hickmott. Mr. H. Lamb remarks that "this is rather a late date for this bird to occur here, I should think, and at any time I believe it rarely occurs in this district." In his Eggs of British Birds, Mr. H. Seebohm states that, "it has also been known to breed in Kent." Mr. A. G. Butler, in his British Birds' Eggs, says: "I have taken the nests in Kent, both under a furze bush and from the edge of a heathery moor under overhanging ling at the top of a steep bank bounding a little-frequented road." He figures the eggs on plate viii. We have the following localities in which it has either been obtained or observed. According to Mr. G. Dowker " the RingOuzel is, however, scarce, especially of late. I have met with it in the Minster marshes and the Stourmouth district." Nonington, by Mr. W. Oxenden Hamanond; Dover, C. Gordon; Walmer, Rev. B. Austen; Folkestone, H. Ullyett; Dover, Plomley Collection; 
Cobham and Ramsgate, Rev. C. H. Fielding. Mr. W. Prentis says: "The Ring-Ouzel passes through Rainham on its passage north in spring, south in autumn. Always wild, choosing for its perch the tops of trees." It is again mentioned in British Birds with their Nests and Eggs (1903), by Mr. A. G. Butler, who states, "It is known to have bred in the rocky parts of Kent." No precise locality or data are given.

\section{WHITE'S THRUSH.}

Turdus varius, Pallas. Zoographic Rosso-Asiatica, i., p. 449 (1811). Turdus whitei, Eyton. Raver Brit. Birds, p. 92 (1836).

We have no hesitation in retaining Lord Clifton's record and observations on the occurrence of White's Thrush at Cobham, Kent, and in doing so we have added the comments of Mr. J. H. Gurney and Mr. E. Newman.

There is no reason to doubt that a bird of such powerful flight should not find its way into every part of the country, seeking a suitable situation to establish itself. An odd male or female would travel miles in a very short time searching for a mate, and then leave the country if not successful.

Strange Thrush.- " On January 5, 1871, I saw a bird which, on its first rising from some dead leaves in a wood, I mistook for a Woodcock, to which its flight, or the shape of its wings, or both, gave it a marked resemblance. On my advancing to the spot the bird again rose from some dead leaves further on, and settled in 
a low tree near me. I then saw that it was of the Thrush fanily, and resembled the Missel-Thrush in size, though differing so remarkably from that bird in flight and habits. Disturbed from this tree, the bird flew off with the same rapid, low, Woodcock-like flight to another tree, perching on a very low branch, and then dropping down among the dead leaves again, from which, when again flushed, it flew back to its original feeding-ground. I have shot, and shot at, many Woodcocks, and I am quite sure that there are few sportsmen who would not have raised their gun at it as a Woodcock. My own opinion is that this bird was IVhite's Thrush, but I do not wish to force this opinion upon your readers. I would merely remind them that the IVoodcock-like flight and terrestrial habits are among the characteristics noted by Mr. R. F. Tomes in his description of White's Thrush, quoted by Mr. Gould in his magnificent wor's, The Birds of Great Britain. Clifton, September 26, 1871."-Zoologist, 1871, p. 2845.

White's Thrush.- "It is a curious coincidence that two specimens of this rare Thrush have been this year (1871) recorded in the Zoologist as occurring on succeeding days; the first seen in Kent by Lord Clifton on January 5 ; the other killed on January 6, at Langsford, in Somersetshire, as noted by Mr. Cecil Smith, and I take the liberty of calling attention to this interesting approximation of dates."-J. H. Gurney, jun., November, 1871.-Zoologist, 1872, p. 2912.

\section{Collected Observations on White's Thrush.} (Turdus varius, Pall.). By Edw. Newman.

After giving the records of eleven instances of the bird having been procured, he says: "In addition to 
the specimens actually 'obtained,' several others may be mentioned as 'seen.' Of these are three good instances.' The second Lord Clifton records, at p. 2845 of the Zoologist for 1871 , that on January 5 of that year he saw a bird which, on rising from some dead leaves in a wood, he mistook for a Woodcock, to which its flight, or the shape of its wings, or both, gave it a marked resemblance. His lordship continues: "On my advancing to the spot, the bird again rose from some dead leaves further on, and settled on a low tree near me. I then saw that it was of the Thrush family, and resembled the Missel-Thrush in size, though differing so remarkably from that bird in flight and habits. Disturbed from the tree, the bird flew off with the same rapid, low, Woodcock-like flight to another tree, perching on a very low branch, and then dropping down among the dead leaves again. My own opinion is that this bird was White's Thrush, but I do not wish to force this opinion on your readers. I would merely remind them that the Woodcock-like flight and terrestrial habits are among the characteristics noted by $\mathrm{Mr}$. R. F. Tomes in his description of White's Thrush."-Zoologist, 1874, p. 4052.

\section{RED-BREASTED THRUSH.}

Turdus migratorius, Limnæus. S. N., i., p. 292
(1766).

American Robin.

With regard to the occurrence of this species in Kent, the only record of it is contained in a communication by Mr. J. E. Harting to the Zoologist, 1877, which is subjoiner. Although we do not agree to its being added to 
the (truly speaking) British or Kentish birds, still it is an accidental visitor. No doubt the bird escaped from a passing up-Channel vessel.

Mr. J. E. Harting, writing on the North American birds found in England, says: "I have now to add another to the list of Passerine birds, in the shape of the American Migratory Thrush (Turdus migratorius), familiarly known as the American Robin. In the month of September last (1876) I received a letter from Lieutenant Charles Pope, of the 24th Regiment, then stationed at Dover, in which he informed me that a friend of his had in his possession, alive, a remarliable coloured Thrush which he was unable to identify. It had been observed to fly in from the sea in a very exhausted state on a wet, windy day during the previous month of April (or May, he was not sure which), and perched upon the first resting-place which presented itself, the balcony of a house facing the sea at Dover, had suffered itself to be frightened in through an open window, and eventually caught. It lived in a small wicker cage from April until September, when I first heard of it, and although the plumage became much soiled by confinement, it remained in good health. From a description and sketch which Lieutenant Pope forwarded, I had no doubt from the first that the bird was the North American Red-breasted Thrush, but it was not until two months later that I was enabled to pronounce with certainty upon the species. Being unable to refer to any of the works on American Ornithology to which I had referred him, Lieutenant Pope prevailed upon his friend to forward the bird to me in London, and I duly received it on November 6 last. My surmise was correct: it was undoubtedly T. migratorius. With the Secretary's permission, I at once placed it in 
the Western Aviary in the Zoological Society's Gardens, where it may still be seen in good health, and in much improved plumage.

"Now, how did this bird get to Dover"? On my mentioning the circumstances of its capture to Mr. A. D. Bartlett, whose long experience as Superintendent of the Zoological Society's Gardens gives weight to his opinion in such matters, he was inclined to believe that it had escaped from some homeward-bound vessel in the Channel, and had made for the nearest land; a view which he thought was strengthened by the fact that the bird when he received it was very tame.

"In this I do not quite concur, for I imagine that most homeward-bound vessels from New York return to Liverpool and not via Dover; while the bird's tameness is easily accounted for by the fact that when Mr. Bartlett received it into his care it had already been in captivity for about six months. I am thus disposed to regard this as a genuine case of involuntary immigration. Many such cases are already on record, and although this particular species is not known with certainty to have occurred here before, it has been met with on more than one occasion on the European continent, and, from its migratory habits, is just one of those birds which one would naturally expect now and then to arrive."-J. E. Harting, Zoologist, 1877, p. 14.

"Mr. Harting forgot that a vast number of European vessels are continually passing up the English Channel for Continental ports from American ports. The majority of the German vessels carry a horde of live mammals and birds, as pets and for profit. If a bird escaped no further trouble would be taken about it, and the owner would never see the Zoologist or hear of the bird's capture in 
England. Singular that it should be found on the most eastern point in England, instead of the nearest western side to America."-E. Bartlett.

\section{Genus SAXICOLA, Bechstein.}

\section{WHEATEAR.}

Saxicola cenanthe (Linnæus). S.N., i., p. 332 (1766). "Wagtail."

There is no doubt that the Wheatear has become greatly reduced in numbers of late years throughout the county, but in some seasons they are more abundant than others; perhaps this may be accounted for by the birds having escaped the trappers and bird's-nesting boys; and again, cultivation, the large increase of population in the localities in which the birds breed, have all helped to drive them away. Years ago many pairs used to breed on the range of chalk hills above Boxley Abbey, and all along that range for miles from east to west, but they have now deserted that locality.

Last year and this (1906) we noticed the scarcity of Wheatears in all the districts from Ashford to Mersham, and the slopes of hills above Romney Marsh, and in the Marsh itself. They become more plentiful on the great sea beach at Lydd and Dungeness, where they are not so easy to get at, and have a better chance of rearing their young.

On June 7 we found a pair which had taken possession of a rabbit-burrow on the hillside on the road to Lympne; the nest was too far down to be reached by the arm. The male bird became frantic at our approach, and went 
through a performance of rolling over, spreading its wings and tail, turning somersaults, lying down, shamming death, sc. A pair bred in a mound of ant-hill turf at Orlestone in 1904-5. It is occasionally seen, according to Mr. R. T. Filmer, in the Orlestone district, but is not so common as at Rye. It is included in Boys' Birds of Sandwich, 1792. Mr. J. Pemberton Bartlett states (1844) that it was " common in Romney Marsh." Among the arrivals of summer birds at Shooter's Hill in 1846, Mr. M. Hutchinson "met a stray Wheatear on WVolwich Common on April 30, and on April 17, 1866, he saw two Wheatears on Blackheath-one among the furze at the north-east corner of the heath; and the other, a fine male in splendid plumage, to the south-west of the Tumulus." Mr. IV. H. Power, in his Birds Observed at Rainham, 1865, says: "They appeared as usual in the spring and autumn, on migration. From its disappearance during the summer months, I fancy it seldom breeds in the locality."

In the Maidstone Musemm there are four eggs, taken at Boxley in Kent, by Mr. A. Harris, in 1873, but Mr. H. Elgar says they "no longer breed in this locality." It used to "breed in the railway cutting, near Allington, some years ago, according to Mr. H. Lamb, and it was not uncommon in 1876 on the Boxley range, and bred in the rabbit-burrows on the chalk hills and other places, and he saw it in early spring on the large fields above the Maidstone Cemetery, at Allington and at Barming, but only when migrating." In 1882 the Rev. C. H. Fielding adds it to the list of "birds found at Higham." In Mr. A. G. Butler's British Birds' Eggs, 1886, he says: "I have hitherto only met with the nest once in Kent; it was placed in a hole in the side of a bank enclosing a water- 
cress stream, in which place it had bred for several successive year's: when I saw it no eggs had been deposited." In the Birds of East Kent, 1889, by Mr. G. Dowker, who says it is "common in his district," the following localities are given: Nonington, Mr. IV. Oxenden Hammond; Dover, Mr. C. Gordon; Elmstone, Rev. W. B. Delmar ; Walmer, Rev. B. Austen; Dover, Mr. G. Gray ; Folkestone, H. Ullyett; Dover, Plomley collection. The Rev. C. H. Fielding includes it among the Birds of the Malling Valley. Mr. W. Prentis, in the Birds of Rainham, 1894, says: "The Wheatear, coming in March, is the first spring arrival. I have noticed some few in summer-tine flitting along our marsh walls, probably breeding in between the blocks of stone used for supporting the embankment." In the Zoologist, 1896, we cull from the ornithological notes from Romney Marsh, written by Captain Boyd Alexander, the following: "The presence here of the Wheatear can hardly escape the notice of the most unobservant. The curious sites chosen by these birds for their nests-and especially is this the case down here-is no safeguard against intrusion, but rather, if anything, the exact opposite, for it seems to linger in the memory of the bird's-nesting boy, with the result that every tin can, kettle and empty shell is zealously turned over and examined, when the Wheatear's treasure is very often found. Though the first nest be taken, it is not uncommon to find the same site occupied again for the second lay. I came across a nest on the 'Lydd Beach' this summer (1896) under a turned-over pig-trough. The hole by which the bird gained access to its nest was no larger than that of a mouse. Another was found in an empty four-pounder shell-a good example, truly, of ' peace and war.' The crevices in the gabion casemates 
here are also frequently chosen. Again, it is not unusual here to find the Wheatear's nest in a depression on the bare beach. In a case like this dry grass alone is used, the nest resembling then a large edition of the Lark's. The normal feather-lining is absent, and $m$ this way conspicuousness is nicely avoided. If not disturbed, I fancy the Wheatear returns annually to the sane nesting-site."

On May 10 and 14, 1900, Mr. T. Hepburn found the Wheatear "nesting everywhere. Found two nests in crevices of the military earthworks, one in an empty shellcase and another in an empty tin can. 'The eggs in one of the nests were fresh, in the other hard set. Jume 3 to 4 : Found a nest with three fresh eggs in a crack in a bank of earth. July 16 to 21 : Old and young birds all over the beach and adjacent meadows."

In his Notes on the Birds of Romney Marsh and Littlestone," May 18, 1902, Mr. E. F. M. Elms writes : "Saxicola cenanthe. A pretty, conspicuous bird, and abundant throughout the district, more especially on the waste lands and the golf-links. Incubation had not apparently become general, and, as a consequence, very few birds flew up from their nesting-holes. One nest only brought to light to-day, and contained five fresh eggs, slightly pear-shaped. May 20: Flushed a Wheatear from a small hole (certainly not a rabbit-burrow) in some open and rather broken ground, near the golf-linlis. Some withered stalks were scattered at the entrance to the hole, some just inside, but the nest itself ras entirely invisible from the outside, and, if the soil had not been loose and giving, I doubt whether I should have tracked the nest at all. 'T'he nesting-cavity contained a fairly compact structurecertainly more compact and bulky than was necessary in such a protected situation-composed of dead grass 
and lined with a little hair and wool. From the groundline to the nest-cavity the distance was a good elbow's length, and the cavity itself was a cul-de-sac branching out of the main hole. This clutch was of six eggs and they were of a much sturdier build than those I had the day before yesterday. Wheatears are called 'Wagtails' by the boys."

Mr. T. Hepburn, in his notes in the Birds of North Kent, 1904, says that between Woolwich and Rochester " the Wheatear is fairly common in the eastern portion of the district during spring and summer, a few pairs also nesting in holes near the sea-wall, but is seldom to be seen any distance away from it; it, in fact, uses the sea-wall as a vantage ground, flitting along in front of the intruder. A full-fledged family, last June (1903), were still making use of their nesting-hole as a retreat, long after they were able to fly. In the autumn, family parties of old birds and the young of the year are very numerous.'

We have seen the bird on the hills above Trotterscliffe and the district. Mr. J. H. Allchin saw a flock passing over Maidstone early in March, 1906. It is a visitor to the Bethersden district according to Captain J. D. Cameron.

In the report of the immigration of summer residents in the spring of 1905 , we find the arrivals of the Wheatear are given as follows: April 2, 1905, Kent, and May 8, 1905, Kent Lights (many), but the bird is observed much earlier than the above dates in many parts of Kent, according to all the above observers. 


\section{BLACK-THROATED WHEATEAR.}

Saxicola stapazina (Vieillot). Nouv. Dict., xxi.,

$$
\text { p. } 42.5 \text { (1818). }
$$

At a meeting of the British Ornithological Club, held on June 20, 1906, "Dr. N. F. Ticehurst exhibited an adult male of this species. The bird was shot between Lydd and Brooklands, in Kient, on May 23, 1906, by a labouring man, and Dr. Ticehurst saw it on May 24. The bird was perfectly fresh."-(Bulletin of the B.O.C., vol. xvi., p. 124, 1906).

\section{Genus PRATINCOLA, Koch.}

\section{WHINCHAT.}

Pratincola rubetra (Linnieus). S.N., i., p. 332 (1766).

The Whinchat is certainly less abundant than the Wheatear in Kent. The habit of this species is to keep more to the inland parts of the country, affecting fields that are partly surrounded by woods, copse and hedges, on which they can rest and keep watch over the nests, which are placed on the ground in the grass a few yards from their perch, and they always take advantage of any elevated ground or mound, large stones or posts. In some large fields two or three pairs will take up positions for breeding.

Writing in 1783, Latham says: "I have seen them in Kent throughout the year." Boys, in his Birds of Sandwich, 1792, calls it "Winchat." Mudie in 1835, says: "It is probable that the Whinchat retires in the 
latter part of the season from all its more northerly breeding places, but that a few pass the winter in Kent and Sussex, even in places where they rarely breed in the summer." In his Ornithology of Fent, 1844, the Rev. J. Pemberton Bartlett states that the Whinchat is "common."

In the Zoologist, 1844, Mr. M. Hutchinson writes: "For hours and hours during the spring of 1843 I listened with mournful pleasure to the plaintive and melodious strains of a beautiful Whinchat. It had many times soothed my sorrowful heart, and for some days I had been anxiously and constantly watching and hoping for the return of my feathered friend. My heart leaped with joy when I again heard the well-known voice of $\mathrm{my}$ pretty Whinchat on the morning of April 18, 1844. I soon spied my old favourite; for even among birds the course of true love runs not always smooth. No sooner had a sturdy Stonechat, located in the same whins, discovered my Whinchat, than, thinking the newcomer's company much too near to be pleasant, he flew at him like a fury, and would not let my little dear have a moment's peace, nor allow him to settle down comfortably, until in a few days the arrival of the Whinchat's lawful partner appeared to satisfy him that his cousin meant no mischief.

"On April 23, 1845, exactly on the same spot as last year at Shooter's Hill, I heard the plaintive note of the Whinchat some time before I could find him. On May 18 I noticed about a dozen male Whinchats in the Eltham Road, apparently resting in their journey northwards. On April 15, 1846, I was much gratified at meeting with my especial favourite, the Whinchat, on Shooter's Hill; the pretty bird, perched on a sprig of 
furze, his colours modest and beautiful, his form elegant and compact, sang his plaintive and pleasing melody. On April 30, 1861, saw one Whinchat at Kidbrooke, springing up catching gnats. On April 23, 1866, strolled round to the south-west face of Shooter's Hill; saw one Whinchat and one Redstart alternately take possession of the elevated stump of an old tree; down went the Whinchat to seize its prey, up went the Redstart; the moment he darted down, up went the Whinchat. On April 27, 1866, in a walk by Kidbrooke, I saw two Whinchats."

Morris, in his History of British Birds, says the Whinchat is "one of the most common visitors in Surrey, Sussex and Kent." Mr. C. Collingwood gives the date of its "arrival at Farm Lane, Lee, Kent, as May 4, 1854." While bird's-nesting in Kent, Mr. A. G. Butler found a nest at Bobbing, "on June 11, 1875, with young birds in it. The nest was placed in a bramble through which furze was growing."

Mr. H. Lamb, in his Birds of the Maidstone District, says that it is "not common here. Last year" (1875) I found a nest with eggs in it, under the eaves of a barn near Farleigh, which I thought unusual, as it builds on the ground." Mr. R. J. Balston made a note in which he says: "I believe I saw a pair of these birds on March 21, 1868, on Boxley Warren, but although I watched and followed, could not get sufficiently near them to be certain." It is also included in the Birds of Higham, by the Rev. C. H. Fielding. There are specimens in the Maidstone Museum, obtained at Linton in August, 1888, and October 25, 1889, by Mr. H. Kennard. In the Birds of East Kent, 1889, Mr. G. Dowlier says it is "moderately common," including Nonington, W. O. 
Hammond; Dover, C. Gordon; Walmer, Rev. B. Austen ; Dover, G. Gray ; Folkestone, H. Ullyett; Dover, Plomley Collection. Cobham, Curton, Ifiełd and Malling Valley, Rev. C. H. Fielding.

In the Birds of Rainham Mr. W. Prentis writes that the Whinchat "comes in April. A pair frequented a narrow coppice on my farm in 1886. On mowing clover a nest was discovered containing four blue eggs, built on the ground; the scythe cut clean over it. The hay-makers were puzzled, never having seen blue eggs in such a place before. It was at least 50 yards from the hedge." In $1902 \mathrm{Mr}$. T. Hepburn observed "a pair on the marshland at Dungeness."

In the Bulletin of the B.O.C., 1906, the date of the arrival of the Whinchat in Kent is March 15, 1905.

\section{STONECHA'T.}

Pratincola rubicola (Linnæus). S.N., i., p. 332 (1766).

\section{Furze-Chat.}

The Stonechat is far from being a common bird in any part of Kent, although it is more often met with on the higher inland furze and heather-covered commons and hills, which it prefers. In the winter it descends to the valleys and lowlands for shelter. In the summer we have seen it and the young birds on the heathercovered hills near Tunbridge Wells, on the Boxley Hills and Blackheath. The first Stonechats met with in Romney Marsh were on December 17, and they remained about the stunted bushes and ditches during the greater part of the winter. We have one which was obtained 
by Mr. R. G. Rogers in February, 1903, at Ivychurch, in Romney Marsh. In his notes on the birds of the Orlestone district, Mr. R. 'I. Filmer states that a pair or two are "usually seen on the railway line, on the Ashford side of Golden Wood, for a few days in spring, and then disappear." The Rev. J. Pemberton Bartlett, writing in 1844, says the Stonechat is "common in Kent." Among the birds mentioned by Mr. M. Hutchinson at Shooter's Hill is the Stonechat: "I heard the chirp of the Stonechat on April 16, 1844." Mr. W. H. Power, in his observations on the birds of Rainham, says it is "a resident species, in the summer frequenting the higher ground, where it breeds; in the winter appearing on the marshes, where I first noticed it this season on September 29, 1865." In Mr. H. Lamb's notes, he says it is "not common about Maidstone." It is included in the birds of Kent by the Rev. C. H. Fielding in his Handbook of Higham, 1882. Specimens in the Maidstone Museum were procured at Linton, on March 30, 1888, and October 25, 1889, by Mr. H. Kennard, and another in Romney Marsh, by Mr. J. D. Parker. In the Birds of East Kent, by Mr. G. Dowlier, the Stonechat is said to be "resident and moderately common." It is also mentioned from the following localities: Nonington, W. O. Hammond; Dover, C. Gordon; Walmer, Rev. B. Austen; Dover, Plomley Collection. It "frequently occurs in the Malling valley," according to the Rev. C. H. Fielding. Mr. W. Prentis, in his Birds of Rainham, 1894, says "the Stonechat is more common with us in winter than in summer." 
Genus RUTICILLA, C. L. Brehm.

REDSTART.

Ruticilla phonicurus (Linnæus). S.N., i., p. 335

(1766).

The immigration of the Redstart into Kent appears to be rather erratic, and its movements uncertain. Some years they make their appearance in numbers, and in others are extremely rare. There is no doubt that the Redstart arrives in Kent in early spring, and then they spread out north and west into the more inland parts of the country to breed, although, when numerous, in some seasons they remain to breed sparingly in several parts of the county.

In 1792 Boys included the Redstart in the Birds of Sandwich. We also find it mentioned in MIudie's British Birls, 1835. In the Rev. J. Pemberton Bartlett's Omithology of Kent (Zoologist, 1844), he states that the Redstart is " common. They arrive here about the first week in April, and leave towards the end of August." There is no doubt in those days the Redstart was numerous enough, but collectors, bird-catchers and others did the mischief, and we must take into accomnt the enormous number that are destroyed on the Continent on immigration, therefore the numbers are greatly diminished.

The following dates are given of the earliest observations of the arrival of the Redstart at "Shooter's Hill, April 5, 1844; Blackheath, April 17, 1861; April 19, 1866, saw one Redstart on the iron rails round the Deodara in Greenwich Park. April 23, strolled round 
the sonth-west face of Shooter's Hill, saw one Redstart. May 4, 1866, the Redstart in Greenwich Park had picked up a wife, and confortable enough they looked." Mr. Hutchinson. Morris, in his History of British Birds, notes that "it occurs in Cornwall and Tales, as well as in Yorkshire and Kent." Mr. C. Collingrood, in his notes on the arrival of summer birds, says: "The Redstart appeared at Blackheath on April 13, 1854, and at Greenwich Park." In Birds observed at Rainham, by Mr. IV. H. Power, the Redstart is said to be "an uncertain visitant, occurring some years in numbers, at other times not to be found at all. In April, 1862, these birds were exceedingly common, while this spring (1865) I only observed two, although constantly on the look out for them. They generally make their appearance as soon as the cherry orchards are in bloom, and may constantly be heard (when in numbers) till the bloom begins to fall; they then appear to move inland, a few pairs only remaining to breed." Mr. A. G. Butler, in his Bird's-nesting in Kent, mentions a nest "taken by Mr. H. Bonnie, at Murston." In the Maidstone district the Redstart, Mr. H. Lamb writes (1876), "is one of those birds which has been, no doubt, common, but now I think it is rarely seen, in comparison to most of the warblers. I saw one at Tovil a few years ago.". Mr. R. J. Balston says: "I have seen it near Boxley late in the fifties." There is a pair of Kentish specimens in the Maidstone Museum, given by Mr. G. Simmons, and Mr. H. Lamb also mentions it at King's Wood. We find it also in Handbook of Higham, by the Rev. C. H. Fielding, and at Nonington, IT. O. Hammond; Dover, C. Gordon; Elmstone, Rev. IV. B. Delmar; Nalmer, Rev. B. Austen; Dover, G. Gray; Folkestone, H. Ullyett; and the Plomley Collection, Dover. 
In the Birds of East Kent Mrr. G. Dowker says the Redstart is "moderately common, scarce of late, which used to be called the Common Redstart. I find it now anything but common. Trne, it may be met with in some localities in tolerable abundance; in the more secluded parts, for instance, of the chalk district, where hedgerows of wild dogwood and guelder rose, entwined with woodbine and clematis, form its sheltering bower. But here, where I ofttimes met with the beautiful little bird, it is now found no more, and even in its favourite localities it is getting scarce." And Mr. W. Prentis, in his Birds of Rainham, states that the "Redstart once was common in our orchards, coming the second and third week in April, and it breeds in the old boundary stumps." In the Bulletin of the B.O.C., 1906, Mr. W. B. Ogilvie-Grant, on the "Immigrations in the Spring of 1905," tells us that " Three distinct immigrations may be noted, of the Redstart, the first and most important of which took place between April 9 and 12, along the south coast, from Dorset to Kent. These birds moved on rapidly to the north and north-west, so that by the 15th there were but few left in the south. On April 21 the second arrivals. On April 27 and 28 the third movement, which extended from Hampshire to Kent, was reported from the lighthouses."

\section{BLACK REDSTART.}

Ruticilla titys (Scopoli). Ann. I. Hist.-nat.,

$$
\text { p. } 157 \text { (1769). }
$$

Although the Black Redstart was at one time looked upon as one of our rarest visitors, it appears to be more plentiful of late years than formerly. The particulars 
which we have been able to obtain prores that the species is an irregular visitor to the county of Kent.

In his Ornithology of Kent (Zoologist, 1841), the Rev. J. Pemberton Bartlett says it is "very rare." The only notice we find in Nenton's Yarrell (1871-74) of this bird is- " to the eastward it is less common, but it has occurred many times in Sussex, and more or less often in Kent, Suffolk and Norfolk."

In the Zoologist, 1883, Mr. IV. Oxenden Hammond states that "on May 9, having been fishing in some preserved water in this neighbourhood (Wingham), I saw a Black Redstart. I was in a raggonette at the time on my may home, and my lieeper was with me and saw the bird as well very clearly. The bird was an old male, as I inferred from the plumage being perfect. It was close to the road and very near to me when I first observed it; and after seitling twice on the ground, just before my waggonette, it flew into a large group of ash and sycamore, and settled against the trunk of a tree near the ground, running up the bark for a few feet in a diagonal position, apparently with ease. It then flew off the trunk into the foliage, and I lost sight of it.

"The bird that I saw on May 9, has appeared therefore at an exceptional season; and since France and Belgium are mentioned as its breeding places there seems to be no reason why it should not breed here, and possibly there may be a pair in the locality where I saw the male." There are specimens in the Canterbury Museum from Dover, and others in the Dover Museum in the collection formed by Dr. F. Plomley.

In the Birds of East Kent, Mr. G. Dorker says the "Black Redstart is rare, but more frequent than formerly ; this is not merely my opinion, but is shared in 



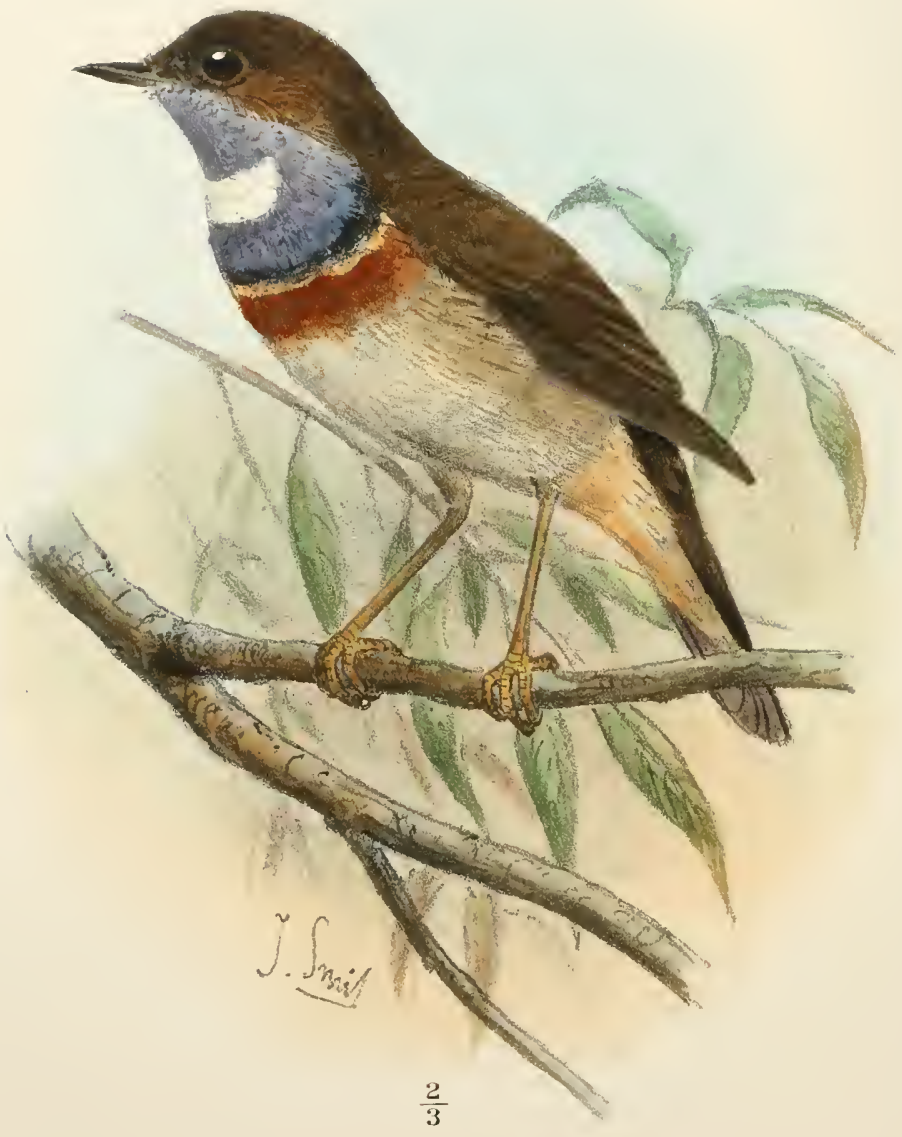

J. Smit del. et lith.

Bale \& Damielsson, Itd imp. 
by that accurate observer, Mr. IV. O. Hammond." The Blackstart, or Black Redstart, so named by the Rev. C. H. Fielding, is included in his Birds of the Malling Valley.

Mr. W. Prentis, in his Birds of Rainham, says: "On October 1, 1865, I observed a Black Redstart with white on its wings fly along a wire fence. An immature bird was caught by a bird-catcher in one of the brickfields, November, 1887."

Mr. S. A. Davies, in his Omithological Notes from East Kent, states that on October 4, 1895, "I visited Mr. Sturgess, the Margate taxidermist, who showed me several Black Redstarts from the district,"

\section{Genus CYANECULA, C. L. Brehm.}

\section{WHITE-SPOTTED BLUETHROAT.}

Cyanecula wolfi, Brehm. Beiträge zur. Vügelliunde, ii., p. 173 (1822).

Naturalists are indebted to Mr. MI. J. Nicoll for the discovery of the first specimen of the White-Spotted Bluethroat in Kent.

We quote the following from the Zcologist, 1902: "At a meeting of the British Onithologists' Club held on October 2.2, I had the pleasure of exhibiting the first authentic British-killed White-Spotted Blnethroat (Cyanecula wolfi). This example, a fine adult male, was picked up dead close to the lighthouse at Dungeness, Kent, by a man named Gasson, on October 6 of this year, and sent by him to Mr. Bristow on October 8, who at that date brought it up to me for examination in the 
flesh. My best thanks are due to Mr. Bristow for bringing it to me, and for lending it to me for exhibition." M. J. Nicoll. In Some Notes of Rare Birds from Hent and Sussex, by Dr. N. F. Ticehurst (Zoologist, 1903), we find the following: "October 6, 1902, a fine adult male of the White-Spotted Bluethroat (Cyanecula wolfi), picked up dead under the lighthouse at Dungeness. It was exhibited by Mr. M. J. Nicoll at the British Ornithologists' Club on October 22, and is probably the first authentic occurrence of this race of Bluethroat in this country."

\section{RED-SPOTTED BLUETHROAT.}

Cyanecula suecica (Linnæus). S.N., i., p. 336 (1766).

The Red-spotted Bluethroat appears to be equally as rare in Kent as the White-spotted Bluethroat. From all the data which we have obtained, only five examples have been procured, and of one observed in Kient we give the following notes: Mr. Morris states that "one was shot at Nargate in September, 1842, and gives the name of Mr. Edward Cole as the authority.'"

From Professor Newton's Yarrell we subjoin his note: "In September, 18t4, two specimens, one old bird, the other a young bird of the year, and both these unskinned, were sent for my inspection by Mr. Gardner. These were said to have been shot in the Isle of Sheppy."

The above specimens are included in Mr. J. E. Harting's Handbook, 1872; in Mr. H. Seebohm's British Birds, 1884; in Mr. G. Dowker's Birds of East Kent, 1899 ; and in the Rev. C. H. Fielding's Malling and its Valley, 1893. 
The capture of the Blue-throated Warbler in Kent is given by Mr. James Green in the Zoologist, 18.53: "A fine old male bird was taken in a nightingale trap, on May 16, 1845, in the county of Kent. I had it alive for several months, and both Mr. Hewitson and Mr. John Hancock, of Newcastle-upon-Tyne, saw it while alive. The latter gentleman now has it in his collection." This specimen is omitted from both Harting's Handboot and Yarrell's British Birds.

In the Zoologist, 1881, Mr. W. Davies, of Dartford, states that "on September 4 (1881) I shot a specimen of the Blue-throated Warbler in the marshes near Dartford. I take it to be the Scandinavian form, as it has a decided rufous spot above the blue breast, the same colour as below the blue band." This is the specimen mentioned in the Field, 1881, and also in the Rev. C. H. Fielding's Malling and its Valley, 1893.

Mr. G. F. Mathew gives an account in the Zoologist, 1890, of the Blue-throated Warbler, observed by himself at Sheerness: "On September 17 I had the pleasure of seeing one of these pretty little birds as it was hopping about among some masses of Atriplex and Chenopodium growing at the foot of the sea-bank beyond Marine Town, Sheerness. It was quite tame and allowed me to look at it for a considerable time as it ran in and out among the plants, occasionally suapping at some insect, or flitting off to a stone on the adjacent shingly beach, where it sat and watched for a few minutes and then returned to the Atriplex, and went on with its search for flies, \&c. It appeared to be a young bird in moult, for I could only see a few blue feathers on its throat, and there was no trace of a white or reddish spot." 


\section{Genus ERITHACUS, Cuvier.}

\section{REDBREAST.}

Erithacus rubecula (Linnæus). S.N., i., p. 337 (1766).

Robin.

Our delightful and garden-loving little Robin, or Redbreast, is the pet of all our resident birds ; there is scarcely an adult, or a child, who does not recognise and adnire our small favourite, in summer or winter, more especially in the latter, when his breast appears redder than ever, and he becomes so sociable and tame that he will enter our rooms for warmth and food and enjoy the shelter of . the home.

The Robin is not only attached to the gardens and houses, but you may find him spread all over the country, along the hedgerows of lanes, where there are ditches; in the woods and fields. In any of these places during the non-breeding season he may be seen sitting on a branch of a tree, or a post, pouring forth his delightful song, which may be heard from autumn till early summer.

Although the Robin is plentiful throughont the county, for we have found him in every district traversed, yet each male holds a particular area to himself and wife, and we have noted him at his regular station from autumn until autumn, and there is no doubt he breeds in that particular area, and the young have to find "fields and pastures new," nor will a Robin allow another male on his estate.

It was not until January 24 that the Robins began to collect in pairs, although the number of males had never 
apparently diminished throughout the winter, but were solitary. The female must remain about the vicinity, but is not noticeable, always keeping closer in the hedges, and allowing her lord and master to keep the coast clear of intruders.

From the early part of March the Robin's song becomes much purer and londer than during November, December, January and February.

The food of the Robin is a very varied mixture, from meat, bread and cheese, worms, insects and fruit. Mr. E. Bartlett tells us that one severe winter while at Maidstone, he saw a Robin on the garden path in the snow, with what he thonght at first was a small twig about 4 inches long sticking out of the bird's mouth. Thinking the bird would injure itself he was going out, but seeing the bird strike the supposed stick on the ground, he knew directly that it was a frozen worm. He watched until the Robin had beaten the worm soft enough to swallow it, there the poor thing stood bolt upright for some time, then hopping under a currant bush until it had fully devoured that horrid frozen worm.

The Redbreast is included among the Birds of Sandwich, 1792, by Boys, and the Rev. J. Pemberton Bartlett, in his Ornithology of Kent, 1844, says it is "abundant." Mr. C. Collingwood, writing in 1854, states that "among the indigenons birds of Blackheath the Robin commenced singing on January 1, and sang bravely through all the winter frost and snow; and recommenced singing on August 5, 1854. I am much inclined to believe that, at least in the majority of instances, the birds which first begin by favouring us with their long-lost voices in the autumn are the young birds of the year; in some cases I am sure of it, from having seen the young birds them- 
selves utter the note to which my attention has been directed owing to its having been so long silent. I do not assert that they alone sing in the latter part of the season, but I believe they are generally the first to break the autumnal silence. The Redbreast is by far the most indefatigable vocalist; throughont the whole rear he was silent only from July 17 to August 6, and then the quiet was profound; for weeks together his was the only roice heard, and nothing seems to impair his powers; so incessant is his music that the small recording voices of his progeny are unbeard."

Mr. A. G. Butler while bird's-nesting in Kent, found at Murston, May 26, one egg pure white, the reddish dots being few.

In Mr. H. Lamb's notes, 1876, he writes: "I have heard of a Robin which built its nest on a shelf in a shoemaler's work room and brought up its young. The shoemalier would sometimes throw pieces of tallow down on the floor and the bird would fly down, pick them up, and take them to the nest." The Robin is added to the Birds of Higham by the Rer. C. H. Fielding. In the spring of 1883 , Mr. A. G. Butler describes the variation of nests of this bird: "I took a large nest of a Robin, over" 5 inches in diameter, from ivy upon the front of a house. This nest is strongly built of fine roots, bass, coarse hair, a few withered grasses, and a little moss, firmly interwoven; the back wall of the nest is about 2 inches in thickness, gradually diminishing towards the front, which is covered with dead oak-leaves, giving it the appearance of a Nightingale's nest; it contains six eggs, almost uniform in tint, the large end of a pale russet tint, growing gradually paler towards the smaller end; no distinct mottling is visible, but two or three isolated darli 
brown points can be seen with a lens on some of the eggs. This nest forms a marked contrast to one which I took two or three years ago out of a hole in an apple-tree; the latter is semicircular in form, and is composed of moss and fine root-fibre, lined with hair, fibre and two or three small pieces of withered grass."

Writing from Thanet, Mr. H. S. D. Byron says: "On May 22, 1888, I found a Robin's nest from which the young had flown; it, however, contained an egg, evidently bad from its discoloured appearance. As this egg was of most unusual size I cut it open and found it contained two dead young birds, each perfectly formed and almost ready to have burst the shell. The shell was rather large in the middle, tapering off to each end, and the birds were placed with their heads towards the points, the small portion of unconsumed yolk being between them in the middle of the egg. The colouring of the shell, however, was collected chiefly at one end, as is generally the case with Robin's."

About Orlestone Mr. R. T. Filmer says it is "common." Mr. G. Dowker says it is "common in the district of Stourmouth." Nonington, IV. Oxenden Hammond; Dover, C. Gordon ; Elmstone, Rev. IV. B. Delmar"; IValmer, Rev. B. Austen; Dover, G. Gray ; Folkestone, H. Ullyett; and Plomley Collection, Dover. "Resident all the year," Rev. C. H. Fielding, Malling and its Valley. "The familiar Robin makes itself at home everywhere," Mr. W. Prentis, Birds of Rainham. Bethersden, Captain J. D. Cameron. "A Robin's nest with five eggs was found at Elmstead in Kent, February 5, 1906."

Note on Mis-coloured Eggs._. "Those who collect the eggs of birds well know how different the colour and 
markings are in different specimens of the same bird. During the summer I found a nest in some ivy containing same milk-white eggs; on revisiting it I found it to be a Robin's, as the old bird was sitting. I saw the young birds also after they were hatched. In a housesparrow's nest, among three eggs marked as usual I found one with the spots of a light red colour, in every other respect it resembled the rest."-J. F. Streatfield, Chart's Edge, near W'esterham (Zoologist, 18t6, p. 1393).

\section{Genus DAULIAS, F. Boie.}

\section{GREA'ER NIGHTINGALE.}

\section{Daulias philomela (Bechstein). Ornith. Tasch. Tög. Deutsch. (1802-3).}

In the last two lines of his article on the Nightingale, in the fourth edition of Yarrell's British Birds, Professor" Newton has expressed his opinion that "there is no sufficient reason for supposing that the larger Nightingale of Eastern Europe has ever risited this country."

The only record, which is certainly very slight, of the Greater Nightingale having visited Kent, is published in the Zoologist, 1896 (pp. 192-3), and added to this work on its own merits :-

Greater Nightingale in Kent. - Writing from Frinsted, Ient, on May 5, 1896, Mr. Gervesse F. Mathew says: "I saw a couple of queer warblers yesterday, and, while they are fresh in my memory, will describe them. They were considerably larger than Nightingales, stoutly and robustly built, of a smoky olive-grey colour, under parts lighter; tail short and square; beak strong, 
shining brown or black; large black eyes. They were evidently a pair, and where chasing each other about; they came quite close to me, and I had them in view several minutes. Their note also was quite strange to me. What could they have been? I have never seen anything like them before. They were in a small coppice by the side of the road between this and Sittingbourne."

On this communication the Rev. MI. A. Mathew observes: "I enclose a note from my brother. The strange warblers are, without any doubt, Daulias phitomela, the Nortbern Nightingale, of which, as yet, there is no record in this country that I know of. My brother's description of the birds tallies closely with that given by Mr. Dresser in Birds of Europe."

Since the above was written the following particnlars of the occurrence of this species in Kent was given by Mr. MI. J. Nicoll in the Bulletin of the B.O.C. (vol. xv., p. 20, 1904-5) :-

"A male of the 'Sprosser' Nightingale (Daulias philomela). This specimen, the first authentic British-lilled example of the species, was obtained at Smeeth, in Kient, on October 22, 1904. It was forwarded for preservation to Mr. Bristow, of St. Leonard's, who kindly brought me the bird in the flesh for examination, and subsequently sent it to me for exhibition."

\section{NIGHTINGALE.}

Daulias luscinia (Linnæus). S.N., i., p. 328 (1766).

The Nightingale is one of our most attractive summer visitors, and all rejoice to hear its welcome voice in early spring, joining in, as it does, with the revival of all animated Nature. 
This species appears as abundant as in former days, and the regularity in the time of arrival and departure is only affected by the conditions of the weather. They have a better chance of increasing in numbers by their babit of remaining within the preserves and on private property.

Soon after the arrival of the Nightingales they rapidly become distributed all over the county, and in some places they are more abundant than others; this may be attributed to the greater supply of food and the best situations for breeding.

In 1792 Boys added the Nightingale to the Birds of Sandwich. The Rev. J. Pemberton Bartlett, in his Ornithology of Kent, 1844, says it is "abundant." Among the arrivals at Shooter's Hill, Kent, Mr. M. Hutchinson gives the following notes: "April 16, 1844. The glorious Nightingales revisited their fatherland the same night of April 15, but I did not hear them till the 18th, when I purposely betook myself to theil shady haunts. Early on Sunday morning, April 13, 1845, as I sat in the wood musing on the sins and somows of the city, compared with the innocent Arcadian revelling in the luxuries of the 'incense-breathing morn,' 7s. a week, a wife and ten fine children, a Nightingale darted close by me into a furze thicket. There goes his red tail, and now he returns thanks for his safe arrival home, in what the bird fanciers technically term 'the sweet jug-andwater bubble.' Later in the day a shepherd boy heard another Nightingale on the opposite side of the wood. On April 27 the Nightingale trappers were out in the woods in full force with their wives and children. I soon heard the call of a Nightingale, saw him drop, down went the trap, rush like madmen went the trappers to find 
who had caught the poor victim, for which there were laid down no less than seven traps. Half-a-crown bought the bird. On discovering that his leg had been broken by the descent of the wire I gave him his liberty two miles from where he was taken. The following Saturday, May 3, observing a pair of Nightingales feeding in the grass slirting the roods, and that one had a very singular gait, I looked through the telescope, and immediately discovered my poor broken-legged Nightingale limping about in rare good spirits; supporting himself with one wing he managed to hobble along the grass famously. I was overjoyed at again seeing him in his old quarters, so happy under his affliction; and many and many a time, through the spring, have I leaned against a tree and listened with delight to the glorious melody of my broken-legged Nightingale. I considered I had laid out my money well. The Nightingale was heard on April 8, 1846, by residents on Shooter's Hill, and by a woodman on April 9, 1846. On April 11 I saw a hen Blackcap, and at last met with the Nightingale crossing the path in the Castle woods. I soon heard his croak, and then mounting a tree, he poured forth his unrivalled melody. Right or wrong, I took him to be my broken-legged Nightingale. He occupied the same quarters and sang in the same tree. Numbers of traps were again laid for him, but he, gaining wisdom from experience, had learned to withstand the temptation of meal-worms, and escaped them all. As soon as his wife arrived I caught her and let her fly, so that often through the spring I had the pleasure of hearing the luscious notes of her mate. I was told a Nightingale had been heard, and another had been canght, on April 5, 1846. The Nightingale was heard in Shooter's Hill wood on 
April 11, 1861, and again on April 26, 1861. Nay 2, 1861, I saw a Nightingale and a Robin feeding together, and plucky little Robin liept pecking and driving the aristocratic Nightingale away. On April 23, 1866, I saw the Nightingale on the south-west face of Shooter's Hill, Kent." Mr. C. Collingwood notes the earliest arrival "on April 16, 1854, Love Lane, Lee, and Abbey Wood."

In the Zoologist, 1857, Captain H. W. Hadfield describes his experience and observations on the Nightingale in the Tunbridge district, as follows:-

"April 20, 1857 (thermometer 65\%).-At $60^{\circ}$ clock p.m. I revisited the spot where a Nightingale was first heard on the 11th instant. After vainly waiting for some half hour or more, I was returning home disappointed, when the clear but distant notes of one could be plainly distinguished above that of erery other songster. We (for I was accompanied by one of my sons) immediately hastened to the spot. To leave the high road, cross a ploughed field, and clear a hedge, seemed, in our state of excitement, but a momentary affair. As we drew near, not one only, but several of these sweet warbler's were pouring forth their melodious notes at the same moment, apparently vying with each other in eager but peaceful rivalry. We now found ourselves in a lane, bordered on either side by hawthorn hedges, which, like most others in the neighbourhood, had been allowed to grow up in a natural and luxuriant manner; to our left and adjoining the road there was a small plantation, chiefly of oak, but the ground at the foot of the trees was completely covered with tangled bushes and briars; an old, unused cart-road running through the midst of it, on the entrance-gate to which we sat ourselves quietly down to listen to and 
enjoy this unexpected serenade. I never before, that I am aware of, heard more than one or two at a time, but now there were three or four singing at once, and so powerfully that the thrilling sensation caused by it is more easily imagined than described. And what met our eyes was equally astonishing, for we had barely time to take up our post of inspection when my son directed my attention, although it was not needed, to two of these most elegant birds (for the Nightingale, though so modestly attired, is inferior to none in lightness and beauty of form) in pursuit of each other, and so regardless were they of our presence that they frequently, in their winding, passed so close that I could clearly distinguish the colour of the plumage, particularly the reddishbrown feathers of the tail, which was momentarily expanded before alighting on the bushes, which they occasionally did, within 4 or 5 yards of us, when they would at once commence their song, which was generally taken up, or immediately followed, by others that were continually sporting about, occasionally alighting on the ground, and one I saw, but for an instant only, pitch on the public road; they also frequently flew into the leafless oak-trees, where they remained for a minute or so, singing as if they would crack their throats, which were greatly distended. During the continuance of the song $I$ observed that the body was kept in a horizontal position, the head being brought down to a level with the tail, which was, however, frequently flirted up and down at its conclusion, when they would spring up or hop round, reversing their position on the branch. There was, I am inclined to believe, but one female among them, for I saw but one pair chasing about, the rest flying singly; and, as they frequently passed over the open space left 
for the road already referred to, I could not have failed to have noticed it luad there been more than one pair; besides, when the two birds entered a bush together the notes of one only was heard to proceed from it. This charming spot, although so retired, is not more than a hundred yards from the railroad; but I observed that the passing train only caused a momentary cessation of their song, and the shouting and screaming of some children on the road did not even appear to be noticed. Their flight is very buoyant, and they thread their way through the hedgerows and bushes with surprising facility, in a somewhat similar manner to that of the Hedge-Sparrow, but then the wings are more expanded. There is a small lake close to the wood, but so completely shut in and fringed by the underwood, as well as overshadowed by the surrounding trees, that it would probably be unobserved by any less prying eyes than those of an ornithologist or botanist; in fact, it is a spot that seems to combine everything that can make it desirable as a breeding place, so, if undisturbed, they would doubtless remain in what is probably an old and favourite haunt."

Writing in the Zoologist, 1866, on the Birds Observed at Rainham in 1865, Mr. IV. H. Power says: "I can remember the time when this 'sweet songster' was a common bird enough, and almost every hedge and garden had its pair of Nightingales; but of late years, I am sorry to say, they have become gradually scarcer and scarcer. This spring I only heard two, and those only for a few days on their first arrival; they departed again before attaining their full song, which I have always found they take some days to perfect themselves in. This unhappy decrease in numbers is caused, according 
to the villager's, by the numbers of brickfields that have of late years been established in the neighbourhood. Their theory is that the Nightingale objects to the smell of burning bricks. How far this may be true I leave others to judge; but the fact of their scarcity is, unfortunately, undeniable." Mr. H. Lamb remarks that the Nightingale is a "common bird near Maidstone. On July 2, 1891, and again on the 8th, I heard the Nightingale singing on the wooded banks of the Medway, above Maidstone." It is included in the summer visitors to the Malling Valley and Higham by the Rev. C. H. Fielding. It is common in the Stourmouth district, according to Mr. G. Dowker; and at Nonington, IV. Oxenden Hammond; Dover, G. Gray; Elmstone, Rev. W. B. Delmar ; Walmer, Rev. A. Austen; Dover, C. Gordon; Folkestone, H. Ullyett; Dover, Plomley Collection.

Mr. R. J. Balston notes: "On April 16, 1902, I heard a Nightingale singing at 9.30 p.m., and one singing on June 9 about 10 p.m.; it struck me that its notes were much softer and sweeter than when it first arrived, and there was no 'jug-jug-jug.' I have heard the Nightingale singing every hour of the twenty-four."

Among the spring arrivals near Canterbury, Mr. D. F. Warde, on April 15, 1906, says: "While walking in a small wood with two friends I heard and saw a Nightingale, but as I had only just come from town I cannot state if it was heard earlier."

The Nightingale was evidently kept back by the cold weather throughout the spring of 1906, and it was not until April 16 that the bird was heard near Maidstone, and on April 23 at Bilsington Woods; after these dates they became general and in every direction. Bethersden, by Captain J. D. Cameron; plentiful about Orlestone, Mr. R. T. Filmer. 
Mr. W. Prentis says: "What would a country life be worth in the south of England without the far-famed Nightingale?"

In the Record of Summer Arrivals for 1905, published by the British Ornithological Club-April 13, 1905, Kentish Knock; and May 6, 1905, Kent is mentioned.

Mr. A. G. Butler obtained the nest at Murston, in May, 1875. He remarks: "I have not seen the nest of this bird for three years, yet I lnow it to be common in all the woods between Herne Bay and Maidstone, and probably all over Kent; I have often heard as many as five birds singing at a time. The Nightingale was very common during the present year (1883), but I only twice stumbled across the nests; in both cases they were normal in structure and position, but last year I found the nest built fully 18 inches from the ground in a matted bush of furze and brambles, near Sittingbourne, Kent. About eight years ago I saw a nest without eggs in a stunted hawthorn, nearly 2 feet from the ground, in Herne Wood, near the village of Herne, Kent."

Blue Eggs of the Nightingale.- "On May 22, after half an hour's careful stalking and searching, I was fortunate enough to find in a wood near Willesborough,

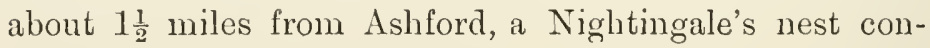
taining five eggs, which were of a beantiful greenish-blue, the same colour as those of the Whinchat, and minutely spotted and speckled in a zone at the larger end, in the same manner as those of the bird just named. On the 29th my brother discovered a second clutch of four eggs of the same bird, within 30 feet of the first nest, the eggs being of the same colour and marking. I find that Mr. Miller Christy mentions this variety in his Bird's-nesting and Bird-skinning, but I believe they are anything 
but common, for although I have found numbers of Nightingale's eggs, this is the first instance in which I have obtained the blue variety."-P. F. Bunyard, Ashford, Kent (Zoologist, 1891, p. 427).

\section{Genus SYLVIA, Scopoli.}

\section{WHITETHROAT.}

Sylvia sylvia (Linnæus). S.N., i., p. 330 (1766).

Meggie, Peggy, and Jolly Whitethroat.

The Whitethroat is generally distributed over the whole of Kient, but it prefers the large inland heaths, commons, and thickly overgrown copses and small woods, especially those places which are well covered with furze and tangled masses of brambles. In such situations the Whitethroat may be seen in all his liveliness and activity, darting from time to time up into the air, chattering, and flittering back to the same place.

The first that was seen at Ruckinge was on May 13, 1906. It was feeding on the aphides on the undersides of the leaves of a small sycamore close to the window, very early in the morning. On the 25th the first nest was found, containing five eggs; it was a very light structure, placed in a small low bush. The second nest was found on May 29, and contained five eggs; this was about a foot from the ground, placed in a very pretty position, in among brambles, primroses, bluebells, tall grasses.

Mr. M. Hutchinson records in the Zoologist the following data of the Whitethroat: "On April 19, 1844, I discovered the fidgety, sancy, chattering Whitethroat on Shooter's Hill. It was not long before up he flew, making 
in his short flight what that close observer and accurate describer, White of Selborne, quaintly terms 'those odd jerks and gesticulations' which so clearly distinguish the Whitethroat from all his congeners. When this bird ceases its chatter-which is but seldom-and really sings, its song is very pleasing. A joyous trio I heard in the Castle wood, by a Nightingale, a Blackcap and a Whitethroat, far surpassing all the squalling of the opera. At Shooter's Hill, on April 23, 1845, exactly on the same spot as last year, I this morning discovered the two Whitethroats. In the same locality on April 19 and 26 , 1861, I found the Whitethroats had arrived. On April 30 the Whitethroats alone are plentiful; I find them creeping abont the nettles at the bottom of a warm, thick thorn hedge, picking up the small black ground-spiders and the red ants."

Among the arrivals at Annerly, Mr. C. Collingwood gives the "Whitethroat as Apr'il 14, 1854."

On April 18, 1902, one was heard in Barrow WTood, Kent, and another obtained on April 25.

MLr. A. G. Butler, while bird's-nesting in Fent in 1875, obtained a nest on May 24-the eggs were sap-green, mottled-at Rodmersham.

Boys includes the Whitethroat in the Birds of Sandwich, 1792. The Rev. J. Pemberton Bartlett, in 1844, says it is "common in Kent." Morris, in his History of British Birds, says it is "to be seen in every county of England from Kent to Comwall." "It is common in the Maidstone district," according to MIr. H. Lamb; and common about Orlestone, Mr. R. T. Filmer; Bethersden, Captain J. D. Cameron; Stourmonth, G. Dowlier ; Nonington, W. O. Hammond; Dover, C. Gordon; Elmstone, Rev. IV. B. Delmar; Dover, G. 
Gray ; Walmer, Rev. B. Austen; Folkestone, H. Ullyett; Dover, Plomley Collection. "It is a summer visitor" to the Malling valley, Rev. C. H. Fielding, and the Higham district, Rev. C. H. Fielding. Mr. W. Prentis, in his Birds of Rainham, says that it "is provincially called Jolly Whitethroat."

In the Bulletin of the B.O.C. for 1906, the arrival of the Whitethroat in Kent is April 11 and 12, 1905.

\section{LESSER WHITETHROAT.}

Sylvia curruca (Linnæus). S.N., i., p. 329 (1766).

\section{Meggie Whitethroat.}

The Lesser Whitethroat is certainly far less abundant in Kent than its larger ally, the Whitethroat. Very few appear to remain to breed around the coast-line, and they no doubt go far inland to the river valleys, and places sheltered from the north-east winds.

With regard to the dates of arrivals the following notes have been brought together: The Rev. J. Pemberton Bartlett, writing in 1844, says it is "not uncommon. Both the Whitethroats arrive about the first or second week in April, and usually depart about the end of August." Mr. M. Hutchinson, writing from Shooter's Hill, Kent, states that "on the morning of April 17, 1844, I fell in with the Lesser Whitethroat, and narrowly watched it with my glass for half an hour, as it kept creeping through the intricacies of a thick thom hedge. It is a neat, modestly attired bird, and is the clearest, most liquid whistler we have. On April 23, 1845, I first saw the Lesser Whitethroat. At the same spot as last 
year, on April 12, 1846, I heard and saw the birds. On Monday, the 13th, I met with Meggy Whitethroat at the old place. There he was, with his dark smoky head and bright throat, magging as incessantly as ever. I had not watched him long before up he went, jigging his long tail and singing most happily."

Mr. C. Collingwood states that the Lesser Whitethroat was first noticed among the arrivals at Blackheath on May 5, 1854. The first observed among the arrivals in the Bilsington district was on April 23, 1902. Among the arrivals recorded in the Bulletin of the B.O.C., the Lesser Whitethroat came on May 1, 1905, Kentish Knock.

In the Birds of Rainham, Mr. W. Prentis says it is "not very numerous as a species." In the Stourmouth district it is "moderately common," G. Dowlier. Bethersden, Captain J. D. Cameron; Nonington, IV. O. Hammond; Dover, C. Gordon; Elmstone, Rev. IV. B. Delmar ; Walmer, Rev. B. Austen ; Dover, G. Gray; Folkestone, H. Ullyett; Dover, Plomley Collection; Maidstone, H. Lamb.

There are nests and eggs in the Maidstone Museum, obtained at Boxley, Malling, and Linton ; this latter nest and five eggs were obtained in May, 1894, by Mr. H. J. Colyer; it was built in a gooseberry bush.

\section{ORPHEAN WARBLER.}

Sylvia orphea, Temminck. Man. d'Om., p. 107 (1815).

On the authority of Mr. G. Dowker, in his Birds of East Kent, this bird is included in this series. He says, "It is a very rare accidental visitor, and the only 
specimen is in the Dover Museum, procured by Mr. C. Gordon,"

\section{BLACKCAP.}

Sylvia atricapilla (Linnæus). S.N., i., p. 332 (1766).

After the Nightingale, there is no doubt that the Blackcap calls forth much pleasurable attention from his charming song. As soon as he has taken up a position, after his arrival, there you may find him sitting in a tree, singing his best, filling the woods with joyful music, and there he remains until his "ladye love" makes her appearance. The Blackcap appears to hold his own, at present, throughout the beautiful woodlands of Kient, and the numbers do not visibly diminish, in fact, they apparently increase, or one pays more attention to their song than before.

The habits of this bird resemble somewhat those of the Nightingale; it prefers the outslirts of low woods and thickets, with a few trees mingled with it, as a lind of watch tower, from which it is to be seen continually darting up and down during the breeding season.

Boys adds the Blackcap to his Birds of Sandwich, 1792. The Rev. J. Pemberton Bartlett in 1844, in his Ornithology of Kent, says the "Blackcaps arrive here about the middle of April, and are rarely to be seen after September, although an instance is recorded of a Blackcap being shot in Kent as late as January. It is frequently called the 'Kentish Nightingale,' which epithet it deserves, for its notes are wildly melodious."

Among the arrivals of summer birds at Shooter's Hill, in Kent, in 1844, Mr. M. Hutchinson gives the following notes of this bird: "On the morning of April 9, 1844, 
the merry Blaclicap announced his arrival. His lighthearted welcome greeted me as I mounted for my morning's ride. Perched on the highest twig of a lofty lime, he sang away cheerily and lustily, that his loving mate might not miss him on her passage. Several successive mornings I saw him singing from the top of the same tree. It is delightful to listen to his varied, happy song; he deservedly ranks among our best singers. I was greatly disappointed at not meeting with the Blackicap from April 6 to 9 (1845). I beat up his usual quarters every morning, without finding him, till April 23, when, instead of exhibiting on the tops of the trees the restless anxiety and excitement of a first arrival, anxiously looking out, and incessantly singing for a partner, he was composedly enjoying in the depth of the underwood the soothing society of his red-headed wife. I concluded the late opening of the buds had delayed his joumey, and he had picked up his mate while travelling through France. Shooter's Hill, 1846: I had for days regularly beat up the haunts of the Blackcap, and felt some disappointment at not meeting with him, when on March 28, while pruning a rose-tree at midday, I heard the well-known notes of that merry bird. I darted off for my glass, and soon saw our Blackcap, in blooming condition, singing away in the highest spirits. I was delighted beyond measure to hear our welcome friend once more. This morning, April 1, 1846, I heard several Blackicaps in full song. On April 11 I saw a hen Blaclicap."

It was not until April 11, 1854, that Mr. C. Collingwood noted the arrival of the Blackip at "Plumstead Common." The dates of arrival of the Blackcap in Kent given in the Bulletin of the B.O.C. are: "Kent, March 27, 1905; April 9, 1905 ; April 10, 1905." The first 
seen in the woods at Ruckinge was on May 5, 1906, and the first nest was not found until Jume 8, 1906, in the Orlestone district.

In the Birds of Rainham Mr. IV. Prentis says: "The merry Blackcap comes in spring, rather earlier than the Nightingale." It is also mentioned from the following localities: Bethersden, Captain J. D. Cameron ; "A summer visitor to the Malling valley," Rev. C. H. Fielding; "In the Stoumouth district it is common," G. Dowker ; Nonington, IV. O. Hammond; Dover, C. Gordon; Elmstone, Rev. IV. B. Delmar; Walmer, Rev. B. Austen ; Dover, G. Gray ; Follestone, H. Ullyett; Dover, Plomley Collection. Mr. H. Lamb found it breeding in the Farleigh VVood, on the Medway, in 1875. The Blackcap is evenly distributed over the Orlestone district according to Mr. R. T. Filmer, with a decided liking for the rough railway banlis on the Ashford side of Ham Street Station.

Mr. A. G. Butler, in his Bird's-nesting in Kent, records the Blackcap's nest on the following dates: "Murston, May 24; Borden, May 25; Barming, June 7 and 8." "The eggs vary in tint considerably more than those of the Garden IVarbler [so he states in his British Birds' Eggs]. The red is of one clutch which I took at Tunstall, in Kent, on May 24, 1877, and on the 29th of the same month, in 1878, I took a second clutch of five eggs, slightly larger but similarly coloured, within a hundred yards of the place where the first was obtained; if these were laid by the same bird, as seems likely, it would tend to show that the red colouring was confined to individuals of the species."

'The following notes are given respecting the song of the Blackcap: Mr. C. Collingwood states that the "bird recommenced singing on August 30, 1854"; Mr. F. D. 
Power, writing in 1868 , says: "One remained about the garden at Rainham, in Kent, till September 16, singing occasionally, but feebly, up to the last."

On the authority of Mr. Morris, in his History of British Bircls, under the heading "Blackicap," one has been killed in Kent in January.

On January 14, 1907, Mr. H. Elgar, of the Maidstone Museum, writes: "I thought you would like to know of the occurrence in Maidstone of a Blackcap. For some days past I had noticed a strange bird in the garden where I live (Upper Fant Road), and yesterday afternoon it came near enough for me to see it was a female Blackcap. It was feeding close to the back door with the following birds: Blackbird, Thrush, Hedge-Sparrow, Chaffinch, House-Sparrow, Robin, Blue Tit, Great Tit, Coal Tit, Marsh Tit and Starling. I saw it again this morning at breakfast-time."

Note upon the Blackcap (Sylvia atricapilla).- "It seems to be an undecided question amongst naturalists whether this pretty little warbler does or does not remain with us during the winter months. There is considerable reasonableness apparently to be said on either side, pro and con; at the same time I do think, when one reflects upon the nature of the bird under discussion, its usual food, \&c., that to any observant and clear-sighted judge the evidence must appear stronger in favour of the latter than the former, i.e., rather against its wintering here, either as a regular, ascertained fact, or as a very common occurrence. As a motive for my thinking thus, I would state an experience which caused me to come to this conclusion in respect to Sylvia atricapilla's residing in our leafless bowers during the coldest portion of the year. Living in a retired and beautiful village not far 
from Dover, some three or four winters since a Blaclicap was brought me by some boys, in the month of December (if my memory serves me), which had been what they termed 'run down' (a cruel and barbarous amusement much practised by lads in this part of England, and not, I fear, an obsolete custom in other countries). Snow was on the ground; the weather quite in accordance with the season; and most of the feathered tribe, tamed by lack of food and coldness of the atmosphere, sought rather the haunts of men than the wide, open woodlands of Nature, their delight in the joyous days of June. Our little friend, wrested from the grasp of unfeeling creatures as well as natural privations, gradually recovered, and seemed to regain its wonted sprightliness. For more than a month I kept it confined in a cage, feeding it as well as I was able on the few insects, \&c., which were to be found; but in that respect I can safely say it had sufficient to support its existence. Towards the end of January the following year, the coldness of the weather increased, and in consequence I firmly believe my pretty prisoner met an untimely end, and fell a sacrifice to a season it was never adapted to contend against; for one frosty morning, on paying my customary visit, I found the little fellow stretched at the bottom of his cage, lifeless, and frozen to death. If such be the fate of one in a comfortable room, what must be the fate of others in the open air, exposed to the blasting winds of winter?" - WV. H. Cordeaux, Canterbury, January, 1851 (Zoologist, 1851, p. 3054). 


\section{GARDEN WARBLER.}

Sylria salicaria (Linnæus). S.N., i., p. 330 (1766). Sylvia hortensis (Gmelin). S.N., i., p. 95.5 (1788).

\section{Greater Petty-chaps.}

The Garden Warbler being rather an obscure bird, and very shy, more or less lieeping to the undergrowth and thickets, is overlooked, and no doubt it is less abundant than the Blackeap in some localities. Throughout the districts visited and the beautiful woodlands traversed it was extremely rare during the summer of 1906 ; the first heard and seen was on May 5, and appeared to have arrived at the same time as the Blackcap, in the Bilsington district. In the Bulletin of the B.O.C., 1906, the arrival of the Garden Warbler in Kent is given as May 7, 1905.

The Garden Warbler is more often than not mistaken for the female Blackcap and the larger Whitethroat, The nest and eggs of the Blackcap and Garden Warbler in many instances are so much alike, both in material and structure, and the similarity of eggs, that many expert collectors hesitate before deciding to which they belong.

There is a peculiar coincidence of dates in the arrivals at Shooter's Hill, Kent, given by Mr. M. Hutchinson in the Zoologist, 1844: "The lovely, modest, drab-coloured Garden Warbler arrived on May 7 (1844); his longcontinued, flute-like song is the softest and sweetest of all our Warblers. On Nay 2, 1846, I heard the melodious song of the Garden Warbler. I was more than ever struck with the purity and rich sweetness of 
its deep melodious tone. I found him busily engaged among the young buds of the underwood oak." The Garden Warbler is among the Birds Observed at Rainham by Mr. W. H. Power, 1865. He says it "arrived this year on May 3. It is common in the orchards and plantations, where in early summer it is constantly heard, though seldom seen, owing to its retiring habits." On May 14, 1902, a Garden Warbler was obtained, and this bird had been heard a weel previously, giving May 7 in the Orlestone district for its first appearance.

In Boys' History of Sandwich, 1792, the Garden Warbler is included in the birds of that district under the name of Greater Petty-chaps.

According to the Rev. J. Pemberton Bartlett in his Ornithology of Kent (Zoologist), 1844, the Garden Warbler was "not uncommon." It is also among the Birds of Higham, according to the Rev. C. H. Fielding, 1882. In the Stourmouth district it is moderately common, G. Dowker; Nonington, IV. O. Hammond; Dorer, C. Gordon and G. Gray; Folkestone, H. Ullyett; Dover, Plomley Collection. In the Birds of Rainham, Mr. IV. Prentis observes that "The Garden WVarbler was frequent in our gardens." Bethersden, Captain J. D. Cameron. Mr. R. T. Filmer says the Garden Warbler is rare in the Orlestone district. What few birds have been noticed have been near the bottom of Bourne Wood towards the village of Ham Street.

In Mr. A. G. Butler's Bird's-nesting in Kent, 1875, he mentions the places and dates of nests procured: "Canterbury, June 14, 1875; Barming, June 8. The examples of eggs taken at Barming are very pale, the markings have a washed-out appearance, apparently not being on the surface of the shells." 


\section{Genus MELIZOPHILUS, Leach.}

\section{DARTFORD WARBLER.}

Melizophitus undata (Boddaert). Tabl. des Pl. Enl., p. 40 (1783). Sylvia dartfordiensis, Latham, Ind. Orn., ii., p. 517 (1790).

The earliest notice of this species in lient is contained in Pennant's British Zoology (i., p. 389, pl. lvi., 1776), who called it the Dartford Warbler, and says that a "pair of these were shot on a common near Dartford, in April, 1773, and communicated to me by Mr. Latham. They fed on flies, which they sprang on from the furze bush they sat on ; and then returned to it again." In 1778, according to Professor Newton, "it was described by Buffon, and figured in the Planches Enlumineés in 1783, under the name of Motacilla undata, Boddaert."

Latham, in his General Synopsis (vol. ii., pt. 2, p. 435, 1783), adopts the name of Dartford Warbler, and states that "A pair was brought to me killed by a friend on Bexley Heath, near Dartford, April 10, 1773, while sitting on a furze bush. These fed on flies, springing from the bush on spying one within reach and returning to the same place repeatedly, in this imitating much the manner of our cinereous Flycatcher." J. F. Gmelin, in his Systema Naturce, 1788 (i., p. 958), describes it under Motacilla provincialis, and Latham in his Index Ornithologicus (ii., p. 517, 1790) describes it under the name Sylvia dartfordiensis. In many works on British Birds the two latin names are used, therefore Boddaert's specific name has priority.

The Rev. J. Pemberton Bartlett, in his Ornithology of 


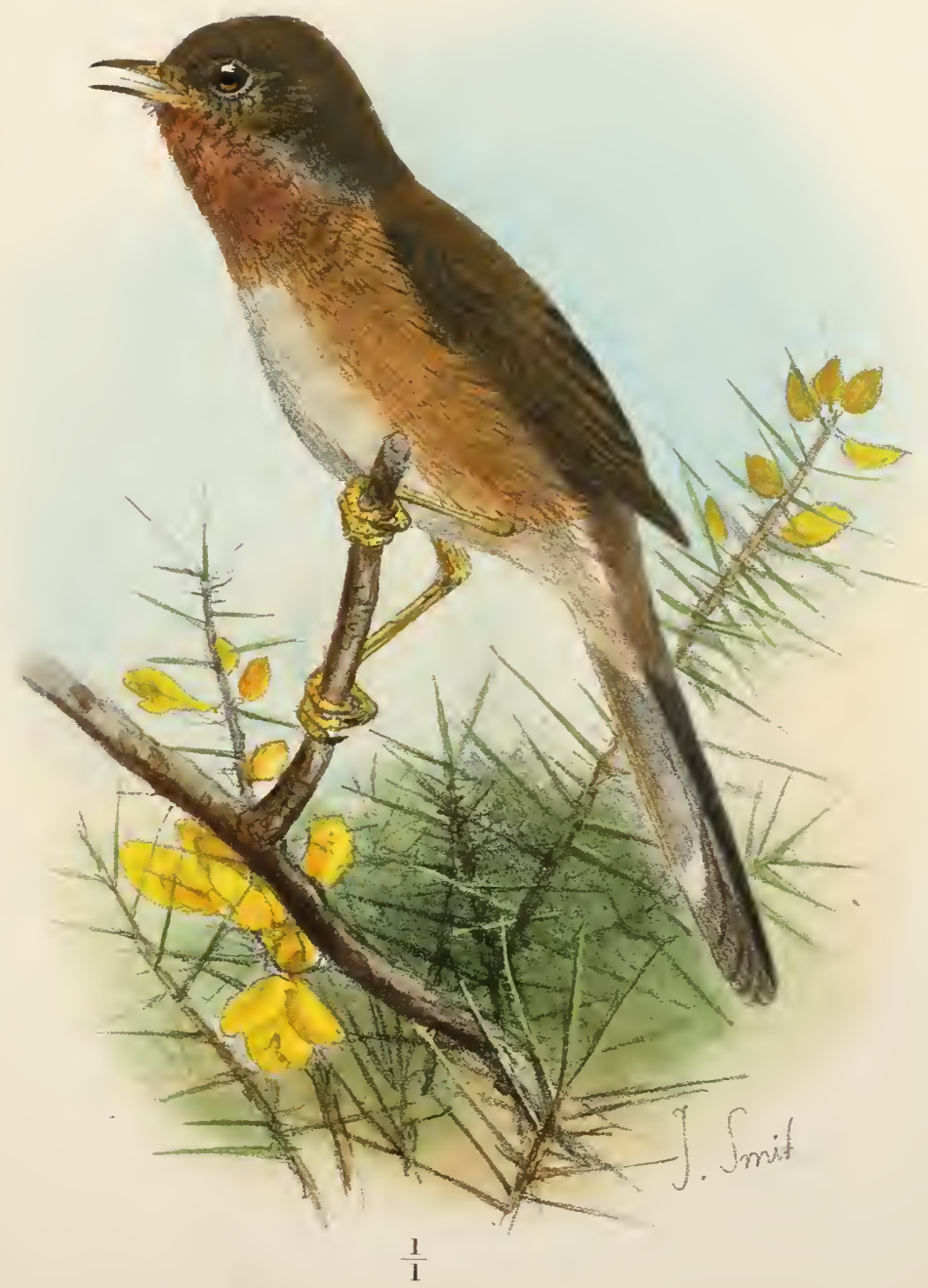

J. Swit del et lith Bale \& Danieisson, L $^{\text {td }}$ imp

DARTFORD WARBLER

MELIZOPHILUS UNDATUS (Bodd.) 

Kent (Zoologist, 1844), truly remarks: "Though deriving its name from a Kentish town, this bird is by no means so common here as in some other parts"; and strange to say, from 1773 to this date no good account of the life-history of this bird appears to have been given of it in Kent.

In the British Museum there are two specimens, a male and a young bird from Kent, presented by Colonel Nontagu.

Rennie, in his Architecture of Birds, says "that he observed it on Blackheath, suspended over the furze, and singing on the wing like a Whitethroat or Titlark, as early as the end of February." Mr. Gr. Dowker, in his Birds of East Kient, 1889, on the authority of Mr. C. Gordon, states that a Dartford Warbler was obtained at Guston in March, 1887. In the Exeter Museum is a Dartford Varbler labelled Kent, which was bequeathed by the Rev. Bower Scott.

The Dartford Warbler on the Banks of the Thames at Woolwich.- "When out shooting on October 1, I saw, lropping about in some blackthorn bushes on the banks of the river, a bird which, from its small size and mouse. like movements, appeared strange to me. It kept so near the ground that it was with difficulty I could get a shot, which only wounded it. I scrambled through the bushes as quickly as possible, but only in time to see it run into a rat-hole. After a fruitless attempt to rake it out with my ramrod I left the spot, but on returning some time afterwards to the same bushes I found it fluttering about in them, and, finding I could not catch it, I fired a second time, fortunately killing it. On examining the bird I found it to be a fine male specimen of the Dartford Warbler. In the stomach I found some small grass- 
hoppers and the wing-case of a small green beetle. When I fired the first time it uttered a cry somewhat similar to the squeak of a mouse." - H. Whitely, jun., Woolwich, October 20, 1863 (Zoologist, 1863, p. 8819).

\section{Genus REGULUS, Cuvier.}

\section{GOLDCREST.}

Regulus regulus (Linnæus). S.N., i., p. 338 (1766).

The Goldcrest is generally distributed thronghout the county of Kent, and it breeds in most of the districts, especially where fir trees are abundant; in these localities it may be found more or less all the year round. It is more conspicuous in autumn, winter and spring, when the trees have lost their foliage, then it may be seen searching for insects in every cone and bud of fir and oak tree.

On Narch 10 one was obtained in Burnt Oak Wood, and several others were seen, and on the 19th of the same month another was obtained on the railway embankment at Horton Green. It was seen feeding in the trees in the garden of the rectory at Ruckinge on October 28, and it was not noticed again until March 10.

This species is included in Boys' History of Sandwich, 1792. It is found in the Bethersden district, according to Captain J. D. Cameron. MIr. J. W. Hulke, in his list of Dates of the Arrival of Winter Visitors to Deal, gives October 13 for the Goldcrest. Writing in 1854, Mr. C. Collingwood states that the "Goldcrest in the neighbourhood of Blackhealth, recommenced to sing on September 12." Mr. H. Lamb, in his notes, says: "This 
beautiful little bird is common in places where there are firs. At Groombridge, a part of which is in this county, it is common, and in Maidstone and the neighbourhood it is not rare. I caught one in August, 1874, at West Farleigh." There are specimens in the Maidstone Musem which were procured at 'Tunbridge and Ulcombe, and nests from the Maidstone and Trotterscliffe districts.

The Rev. C. H. Fielding says the Goldcrest is a resident in the Higham and Malling valley district, and Mr. G. Dowker, in the Birds of East Fent, 1889, states that it is a "common resident in the Stourmouth district," and, on his authority, the following localities are added: Nonington, IV. O. Hammond; Dover, C. Gordon, G. Gray and Dr. Plomley; Elmstone, Rev. W. B. Dehmar; Walmer, Rev. B. Austen; Folkestone, H. Ullyett.

\section{FIRECREST.}

Regulus ignicapillus, Temminck. Ex. C. L. Brehm, Man. d'Orn., i., p. 231 (1820).

The Firecrest is certainly a scarce bird, although it may be mistaken for the ordinary Goldcrest. Very few instances are recorded of it in Kent, which are here subjoined in accordance with the dates.

In Professor Newton's edition of Yarrell (1871-74), he mentions that "one is said to have been taken in Kent." In November, 1876, Lord Clifton states: "I twice saw a Firecrest here (Cobham, Kent), in company with Goldcrests, among bracken. I noticed the black stripe through the eye, which readily distinguishes this bird from the common species." 
In the Birls of East Kent, 1889, Mr. G. Dowker says: "The Fire-crested Wren is very rare; it has been met with on several occasions, and may be more common than is generally supposed, being mistaken for the common Golden-crested Wren: the latter, I often find, builds in my Deodara. A specimen, on the authority of Mr. C. Gordon, was obtained at Whitfield, near Dover, in 1854." The Kev. C. H. Fielding gives Higham and the Malling valley as localities in which it has been found. In his Ornithological Notes from Rye, Captain Boyd Alexander says: "On October 10, a very handsome male Fire-crested Wren was shot to-day on a tall apple-tree, in a garden near Lydd." In the Zoologist, 1906, Captain Boyd Alexander writes that "on March 3, near Tunbridge Wells (in Kent), I saw a small bird in a place where Goldcrests have been fairly numerous this winter, which I supposed to be of that species; however, it approached so near that I was able to see distinctly the black eye-stripe and white eyebrows which are characteristic of the Firecrest. Since then several others, including a well-known ornithologist as well as myself, have several times observed this bird, and a second-no doubt its mate-has also been seen."

At a meeting of the British Ornithologists' Club, held on January 17, 1906, Mr. Wr. R. Ogilvie-Grant " exhibited a male Fire-crested Wren, which had been picked up in a dying condition at Abbey ITood, Kent, on January 10, 1906, and forwarded to the British Museum by Mrs. A. G. Mitchell" (Bulletin of the B.O.C., vol. xvi., p. 45, 1906). 


\section{Genus PHYLLOSCOPUS, Boie.}

\section{YELLOW-BROWED WARBLER. \\ Phylloscopus supercitiosus (J. F. Gmelin). S.N., i., p. 975 (1788).}

Several instances of the accidental visit to Great Britain are recorded of the Yellow-Browed Varbler, and only once to the county of Kent. Dr. A. G. Butler, the well-known ornithologist, writing from Beckenham, Kent, to the Zoologist, 1899, under A Stray Visitor to Kent, says: "On Saturday morning (April 15), whilst eating my breakfast opposite a window facing my garden, I observed a tiny Warbler do me good service by cleaning the aphides from a rose tree. The sun was shining and the bird was only about 8 feet distant from me, so that I could see it quite distinctly; it was about the size of a Goldcrest, but olive-green above, pale yellow beneath, and with a well-defined eye stripe. If this was not Phylloscopus superciliosus I can give no name to it, for it was far too small for a Chiffchaff or a Willow Varbler, both of which I often see, either in the spring or autumn, in my garden. I watched the bird carefully for three or four minutes before it flew away."

\section{CHIFFCHAFE.}

Phylloscopus rufus (Bechstein). Orn. Taschenb., i., p. 188 (1802).

The Chiffchaff is one of the earliest of our summer visitors to arrive in this county, and it may be heard in all our beautiful woodlands in early spring, even before the bushes have developed a leaf. There is a great 
difference in the dates of those first heard and seen in the spring, and no doubt our Chiffchaff can endure a great amount of cold, like his northern ally, Phylloscopus borealis.

Our Chiffchaff comes under the name of Less Pettychaps in Boys' Birds of Sandwich, 1792.

The Rev. J. Pemberton Bartlett states, in his Ornithology of Kent, 184t, that "these birds arrive about the end of March and depart early in October."

'The following are interesting notes by Mr. M. Hutchinson, in his observations on the arrival of summer birds at Shooter's Hill, in Kent: "The Chiffchaff was the first of the absentees whose return I noticed on April 3 (1844); his peculiar and distinct note loudly proclaimed the advent of spring and readily told me of his whereabouts. The following year, 1845, on April 2, I espied a little bird flitting about from tree to tree, and soon heard the peculiar note of the Chiffchaff, the pioneer of the weather. He had, however, but little to say, for he seemed to think, with me, that chewing condensed Thames fog on the summit of Shooter's Hill at break of day was no treat. Extremes met: the bitter winter of 1844-45 was succeeded by the mildest winter known. Throughout Europe the winter was so open that there may be said to have been no winter in 1845-6. In the spring of 1816 I was therefore early on the look-out for the return of my musical friends. Hearing that the Chiffchaff had been seen on February 27, I diligently, but ineffectually, sought it till March 11, when my.old acquaintance, on the top of Shooter's Hill, announced his arrival as the harbinger of a forward spring. Some woodmen had heard one lower down in the woods about a fortnight earlier. On the 12th I observed three Chiffchaffs, and 
on the 27th never noticed them more numerous or noisy." At Blackheath Mr. C. Collingwood first noticed the "Chiffchaff in Love Lane on April 3, 1854, and he says it recommenced to sing on August 31."

Mr. W. H. Power, in his notes in the Birds of Rainham, says: "It is a remarkable fact that, although the Willow Wren is so common, yet the Chiffchaff itself is exceedingly rare in this district. I never heard it before this year (1865), and even then quite late in the season, namely, the second week in September." It is migratory, and moderately common in the Stourmouth district, according to Mr. G. Dowlier, who adds the following localities: Nonington, W. O. Hammond; Dover, C. Gordon and Dr. Plomley ; Elmstone, Rev. WV. B. Delmar ; Folkestone, H. Ullyett. It is a summer visitor to the Malling valley, Rev. C. H. Fielding, It is also found in the Bethersden district, Captain J. D. Cameron; and common at Orlestone and the neighbourhood, R. T. Filmer; and it was heard on April 12, 1902, in the same district. Mr. J. B. Groom, of Maidstone, heard a Chiffchaff on March 3, 1906, on Boxley Hills, in Kent.

In the Zoologist, 1899, Dr. A. G. Butler gives some interesting particulars respecting the Chiffchaff and its nest. "My friend, Mr. George Alcock, who is inuch interested in British birds, sends me the following note, which, I think, is worth publishing: 'A Chiffchaff (Phylloscopus rufus) built in my garden at the top of a yew 10 feet above the ground. It built a second time on the top of a box-bush 4 feet above the ground. I have found scores, but have never before seen one in these positions. In each case the young came to maturity. There were four eggs each time." "

Respecting the Cliffchaff singing in autumn, Mr. A. 
II. Micklejohn, of Ashford, Kient, in writing to the Zoologist, 1901, states: "While dressing on the mornings of September 28 and 29, 1 distinctly heard a Chiffchaft (Phylloscopus rufus) singing, my bedroom window being open at the time. As I was rathel sceptical about it, I went out afterwards in the garden and saw the bird busily feeding among the leaves of a sycamore. I watched it for about a quarter of an howr, and during that short time it sang thrice, not faint-heartedly, but in good voice. I heard it several times afterwards up till one o'clock, when the song ceased altogether. The weather was remarkably' warm and the sun very bright."

Mr. R. J. Balston has heard it at Boxley Abbey very late in the year, and took a nest of this species on May 15, 1879, containing six eggs; it was placed in a butcher's broom bush two feet from the ground; he also heard this bird on March 18, 1880.

\section{WILLOW-WARBLER.}

\section{Phylloscopus trochilus (Linnæus). S.N... i., p. 3:38 (1766).}

The Willow-Warbler is a far more abundant species in the spring than the Chiffchaff, and it does not make its appearance as early as the latter bird. Its soft short song may be heard in all the smaller woods and hedgerows throughout the county in April and May.

The earliest seen and heard in 1902 was on April 16, in Burnt Oak Wood, Orlestone ; and in 1905 the last seen was on October 17, in Romney Marsh, below Ruckinge. It is common in the Orlestone district according to $\mathrm{Mr}$. R. T. Filmer. 
It is under the name of Yellow Wren in Boys' History of Sandwich, 1792. Writing in 1844 the Rev. J. Pemberton Bartlett says "the Willow-Wren is common in Kent."

The Willow-IVren is given among the arrivals of summer birds at Shooter's Hill, Kent, by Mr. M. Hutchinson in 1844, who writes: "As I turned off Woolwich Common (on the morn of April 16), into the brushwood that covers the western face of Shooter's Hill, the jocund spring burst on me with all its charms. The wood rang again with the incessant song of the little Willow- Wren given in all the height of excitement, and singing against each other by scores. For three weeks, morning and evening, I never passed along the Dover road without observing a Willow-Wren sing its utmost on the tip-top of the Lombardy poplar. In the following spring of 184., the IVillow-Wren was found on April 7. On April 3, 1846, as I rode through the brushwood on Shooter's Hill, I observed a little light-coloured bird being driven about by a sturdy Stonechat. The little fellow whipped into a bramble bush, and I instantly heard the joyous song of the gallant little Willow-Wren, a moment after he was paying his respects to a pair of dicky dumnocks; the bird was all excitement, and scarcely knew what to be at. On the 4th I met with numbers of Willow- ITrens on the east of Plumstead Common, and rode with them for some time in their progress westward. This, and other observations, lead me to think that many of the smaller birds of passage came up the valley of the Thames with the river for their guide. At Blackheath the earliest seen was on April 19, 1859, and in 1861 on April 19 and 26. The long and severe winter of 1860-61 delayed the arrivals. On May 2 I saw a pair of Willow-Wrens 
building, and mighty fussy and important they were about it." Mr. C. Collingwood gives April 10, 1854, for the arrival at Elmstead in Kent.

The dates of arrivals in Kent of the Willow-Warbler, given in the Bulletin of the B.O.C., 1905, are April 10, 11, 12, and they increased on April 27 and 28 .

Two or three were observed in the Orlestone district on April 22, 1906, and it was not until April 28 that the first was seen at Ruckinge. It remained feeding on the lawn in front of the house for a week.

Dr. A. G. Butler describes in the Zoologist a nest of this species, and says: "I obtained a nest of the WillowWarbler in which the dome-like covering was wholly absent; the nest was in a most singular position, being placed upon the earth under a gooseberry bush in an orchard, one of the rough clods somewhat overhanging it, and thus rendering the completion of the nest unnecessary. This nest is composed almost entirely of slender dry grasses, thickly lined inside with dark soft feathers; it contains four eggs, which are unusually well marked with large red-brown spots." And in his British Birds' Eggs he remarks: "Though commonly placed upon the ground, the nest is not invariably found in that position; one that I took on June 16, 1881, was built over 2 feet from the ground in the drooping branches of a wild rose-bush in a garden at 'Tumstall in Kent."

Four specimens of this species were shot on April 27, 1879, at Boxley. They were all males and in nonbreeding plumage.

On April 29, 1906, four Willow-Warblers were seen in the sallows overhanging a large pond at Bilsington; they were acting the Flycatcher by springiug up into the air for their prey. 


\section{WOOD-WARBLER.}

Phylloscopus sibilatrix (Bechstein). Naturforsch., xxvii., p. 47 (1793).

The Wood-Warbler does not appear to be a very common species in this county. It prefers large and dense old woods far inland, which are not always accessible to the wandering naturalist. Its habit of keeping to the higher branches of large trees also prevents a closer observation of it. If the voice of this bird is once heard its presence is easily detected afterwards, it being very different from all the other warblers. Several of these beautiful green warblers were observed in the large fir trees in Broadwater Forest near 'l'unbridge Wells in the early autumn of 1905.

The Rev. J. Pemberton Bartlett, in his Ornithology of Kent (Zoologist), 1844, states that this species is common. In the list of arrivals of summer birds at Blackheath, by C. Collingwood, the date is given as May 3, 1854, at Greenwich Park. In the Birds Observed at Rainham Mr. W. H. Power says: "The Wood-Wreu is an uncertain visitant, occurred this year (1865) on April 20"; and Mr. W. Prentis states that it is seen only on passage. According to Mr. R. T. Filmer the Wood-Warbler is not so common as formerly in the Orlestone district. For many years it had a nest on one side or the other of the railway line near Bourne Wood crossing.

It is also included among the birds in the following localities: Higham and the Malling valley, Rev. C. H. Fielding; moderately common in the Stourmouth district, G. Dowker; Nonington, W. O. Hammond; Dover, C. Gordon and Dr. Plomley ; Elmstone, Rev. W. B. 
Delmar; Folkestone, H. Ullyett. An interesting note appears in the Zoologist, 1896, respecting this species, by Captain Boyd Alexander: "The first appearance of the Wood-Warbler in the Cranbrook district this year is a noteworthy incident. The favoured localities are certain spots in the Angley and Bedgebury Woods, where tall firs and beech trees grow. From these high points this daintiest and prettiest of our Warblers proclaimed his arrival on one sunny day near the end of April by the utterance of his peculiarly fascinating song- - ting 'hip hip hip hurra.' The first three syllables are given ont with distinct besitation, a mere prelude wherein to gain strength for the final outburst of song. This finale, which rises in pitch towards the end, and uttered with wings shivering and head thrown back, has all the appearance of being the expression of a deep passion of joy. Then, as if weary with such a supreme effort, it sluggishly flops to a fresh perch, and there gathers strength for another demonstration of its musical capacities. The male of this species arrives here before the female. And as soon as his song has attracted and won a mate, they become less frequent, and cease altogether when the young are hatched."

\section{Genus HYPOLAIS, C. L. Brehm.}

\section{ICTERINE WARBLER.}

Hypolais icterina (Vieillot). None. Dict. d'Hist.

$$
\text { Nat., xi., p. } 194 \text { (1817.) }
$$

Ornithologists are indebted to the late Dr. F. Plomley for the only record of the occurrence of this species in Kent. His account of it in the Zoologist, 1848, is as 
follows: "Those interested in Natural History, more particularly in Ornithology, will be pleased to hear of the capture, for the first time in the British Isles, of the Icterine Warbler ${ }^{1}$ (Hypolais icterina), which was killed at Eythorne, near Dover, on June 15, 1848. It is a beantiful specimen, and in the most perfect piumage, and the person who shot it was attracted by its extraordinary lond and melodious song. It is a species which has hitherto never been found in England, and Gould states, in his Birds of Europe, that it is somewhat singular that this species, so familiar to every naturalist on the Continent, and which inhabits the gardens and hedgerows of those portions of the coasts of France and Holland that are immediately opposite our own, should not, like the rest of its immediate congener's, more diminutive in size, and consequently less capable of performing extensive flights, have occasionally strayed across the Channel and enlivened our glens and groves with its rich and charming song, which is far superior to that of either of the three other species of the group, and only equalled by those of the Blackeap and Nightingale. The bird, beautifully preserved by Mr. C. Gordon, of the Dover Museum, is in the possession of Mr. John Chaffey, of Dodington, whose collection of rare British birds is unrivalled."

The specimen is now in the collection of Dr. Scott, of Chudleigh.

' In the Zoologist, 1848, this bird appeared under the name of the Melodious Willow-Wren (Sylvia hippolais of Temminck). 


\section{Genus ACROCEPHALUS, Nammanm.}

REED-IVARBLER.

Acrocephalus streperus (Vieillot). Nout. Dict. d'Hist. Nat., xi., p. 182 (1817).

This species is very numerous in all the tall reed-beds in the marshes, and on the river banks in various parts of the county. Its favourite haunts are those of reedbound lakes and large ponds, especially those on inland private property, and it is very partial to large patches of lilac bushes, the upright stems of which form a strong support for the nests, which are not only built in a fork, but will also embrace three or four straight, upright stems, answering, as they do, for the stems of the reeds.

The Reed-Warbler is one of the most familiar birds of our overgrown sedge-covered ditches, ponds and lakes. The bird is not silenced by an intruder on its privacy and nesting-place, but will continue its zig-zag notes even when all else is hushed. Its curiosity is very funny, for it will even come close up to one, to make sure of the visitor's presence, before getting out of reach, without the slightest sign of timidity. In the last edition of Yarrell's British Birds it is stated that " the nest and eggs were sent to the late Mr. Lightfoot, from Dartford, in 1783 , by Dr. Latham, who did not know the bird to which they belonged."

In 1802 the species was admitted by Montagu to the Omithological Dictionary, and said to have been found by him along the coasts of Kent and Sussex, from Sandwich to Arundel.

It is common on the Royal Nilitary Canal, more especially at the Rye end, according to Mr. R. T. Filmer. 
The late Rev. J. Pemberton Bartlett, writing in 1844, also states that it is common in Kent.

The following excellent account of the habits and nidification of the Reed-IVarbler appeared in the Zoologist in 1843, written by Mr. W. H. Thomas:-

"These merry, courageous little birds are common within a few miles of London. I have found them in abundance in the reed-beds on the bauks of the Thames, between Erith and Greenwich. In seeling them you must not be afraid of labour in pushing your way through reeds; you must likewise take care to get as firm a footing as possible, for many of these places are very treacherous, and I have more than once suddenly sunk with one leg into a deep hole, and have had some difficulty in extricating myself. When hunting in such places I generally have a stout hedge-stake or clothesprop to try the soundings with.

"From the time that the reeds are half grown until the latter end of July these birds frequent then in abundance, and their nests, with eggs or young, may be readily found. I have taken the young as late as August 13. They continue about the reeds until the middle or end of this month, when I believe they migrate, with the exception of an occasional late-hatched bird.

"The food of the Reed-Warbler principally consists of small spiral-shaped shell-suails, which occur in great plenty in reed-beds, often completely corering the lower part of the reed-stems; they also eat beetles, and a variety of small insects.

"In ditches, where reeds grow thickly, and the sides have plenty of stunted thorn bushes intermingled with brambles and rank grass, the Reed- and Sedge-Warblers (Calamoherpe arundinacea), are close and sociable neigh- 
bouts, and I have frequently found the nests of both species within a dozen yards of each other.

"The Reed-IVarbler's nest is suspended from the stems of the reeds, although the outer branches of the thorn bushes are often entangled with them. The SedgeVarbler's nest is always fixed in the low thorn bushes, and ont of many dozens that I have found, I have never met with one fixed to the reeds, unless a stray stem growing through the bushes has now and then been, as it were, accidentally intertwined from its being placed on an outer branch, but even this very rarely happens. In other places, where reeds have been scarce and not sufficiently thick to hide the nest, by the side of ditches and near gardens, I have found the nest of the Reed-bird placed in closely branched elder trees.

"'The nest of the Reed-Warbler is often elegantly built, and generally fixed to three or four reed-stems. It is composed of slender blades of grass, interwoven with the reed-tops and the dry spongy substance which covers many of the marsh ditches; also dry duckweed, and here and there a long piece of sedge is wound securely around it; the lining is of the finer flowering stems of grass, intermixed with a little horse hair. It is a deep and solid structure, so that the eggs cannot easily roll out; it is firmly fastened to the reeds in tide ditches and rivers, at the height of three or four feet from the water, but in still ditches often not more than a foot.

"'The eggs are generally five, rather larger than those of the Sedge-bird, and are of a greenish tint, thickly blotched with darker ash-colour at the larger end, the smaller end being spotted with light brown; the marlings are of different sizes, and sometimes vary in the same nest. In windy weather, when wading 
through the reed-beds, I have seen nests, with both old and young in them, blown nearly to the surface of the water; but the birds fix their claws firmly to the sides of the nest, with their heads to windward, and thus ride as securely in their cradles as a sailor does in his cot or hammock.

"The nest is rarely blown down, for when the men cut the reeds in winter they frequently find it firmly fixed to the stallss, and call it the "reed-sparrow's."

"As soon as the young ones quit the nest, which they do early, they are very active, and nimbly hop up and down the reed-stems, it matters not which end uppermost; they are very tenacious in their grasp, and very noisy and clamorous for food. Both old and young, at this time, utter a screaming note, something similar to that of young Starlings, with now and then a deep, harsh 'churr."."

Mr. Gould, in his Birds of Great Britain, 1879, says: "It also frequents all the fluviatile districts of Kent, \&c. The incessant babbling made by numbers of this bird and the Sedge-Warbler at sunrise on the banlss of the Thames is beyond my power to describe."

During a bird's-nesting tour in Kent in 187.5, Dr. A. G. Butler found the "Reed-Warbler breeding at Tonge Mill, Tonge, near Sittingbourne, on June 5 and 11 ; two forms of eggs, one greenish, the other greyish, with a cuclioo's egg in the latter."

In his Omithological Notes from Romney Marsh, Captain Boyd Alexander writes: "Many parts of the large dykes and pools have dried up, and are now nothing more than thick reed-beds. In these reedy places the Reed-Warbler has found a home. Any sudden noise will cause this bird to sing vehemently, while the foot- 
falls of a passer-by invariably draws from him a song." Among the birds on the beach at Dungeness, Mr. 'T. Hepburn says: "July 16 to 21 : Found three nests of the Reed-TVarbler in the reeds fringing a pool of water on the marshland, one containing three perfectly fresh eggs, another with three young birds and an addled egg, and a third from which the birds had evidently just flown. The birds were singing all round in the reed-beds."

There are specimens of the nests and eggs of this bird in the Maidstone Museum. A nest from Furnace Pond, Horsemonden, obtained by Mr. H: Usmar; a nest and three eggs from Hollingbourne, taken in June, 1880, by Mr. J. Coveney, and another nest and three eggs, found at East Farleigh, July 12, 1890, by Mr. A. Hunt.

The Reed-Warbler has been noted in the following localities: Bethersden, Captain J. D. Cameron; Stourmouth, G. Dowker; Nonington, Wingham, IV. O. Hammond; Elmstone, Rev. W. B. Delmar; Walmer, Rev. B. Austen; Folkestone, H. Ullyett; Dover, Dr. F. Plomley; the Medway valley, E. Bartlett and H. Lamb.

The bird arrives late in April, but no fixed dates have jet been obtained.

\section{MARSH-WWRBLER.}

Acrocephalus palustris (Bechstein). Om. Taschenb., p. 186 (1802).

Although the Reed-Warbler is so plentiful in all the reed-beds in Kent, the Narsh-WVarbler has hitherto escaped the observations of naturalists in this county, and the only reference to a supposed specimen is con- 
tained in Mr. WV. Prentis's Birds of Rainham, 1894, who says: "I have a specimen of the Marsh-TVarbler-if the distinction is a broader bill than that of the Reed-TVarbler -which was shot in a garden beside a reed-bed at Milton, May, 1866."

\section{GREAT REED-WARBLER.}

\section{Acrocephalus turdoides (Meyer). Vög. Liv-u.- Esthl., p. 116 (1815).}

The earliest and most reliable notices of the occurrence of this species in Kent are as follows:-

The Rev. F. O. Morris noticed one killed by the side of a pond near Sittingbourne on May 4, 18.53. This specimen, according to $\mathrm{Mr}$. Chaffey, of Dodington, was obtained by Mr. G. Thomas, of that place.

One was obtained between Tunbridge and Sevenoaks, and another at Erith; these are given, but no data are attached to them.

There is a specimen of the Great Reed-Warbler, labelled Kent, among the Kentish birds bequeathed to the Exeter Museum by the Rev. Bower Scott; here again no data are attached to it.

The most interesting account of the discovery of this bird in this county was written by the late Mr. WT. Oxenden Hammond in 1881, which is here subjoined:"While snipe-shooting on September 14, 1881, I came across a Warbler of some kind, which I failed to identify satisfactorily, I had marked a snipe down, as I believed, in a watercress-covered stream which flowed between an alder-bed on one bank and a bank of very high reeds on the other. I had not gone far up the windings of this 
channel, pushing aside the tall Lythrum and Eupatoria as I went, when the bird in question rose out of the coarse herbage and instantly entered the reed-bed opposite. Being struck with its appearance, which differed both in size, colour, and manner of flight from the ReedWarblers that I had met with more or less all day, I signalled to my heeper, who was carrying my marshjumping pole, and when he came up I sent my retriever into the reeds where the bird had entered. The bird moved through the reeds at once before the dog, and my keeper seeing it, forced it out by a thrust or two of the pole. It flew along the water-course very low, just topping the cresses, with a weak, fluttering flight, and some dust-shot then struck it down. I anticipated no difficulty in identifying it by a reference to Gould's Birds of Great Britain, and I turned at once to the description of the Thrush-Warbler, Acrocephalus turdoides. Beautiful, however, as are the plates, and admirable as are the popular descriptions in this work, it is unfortunately wanting generally in precise information as to measurements, colour, sc., and in this instance nothing beyond the plate is given towards identifying a supposed specimen. Gould's figure measures 8 inches; my bird measures $7 \frac{3}{8}$ inches. The general aspect, structure and size of the bill, and marlings-as far as the bird possesses them-agree, with the exception of feet and tarsi, which in the coloured plate are of a pale yellowish-brown, and in my freshly killed bird a very decided light bluish-slate colour. Without professing to give a scientific description of my bird, I should describe it as follows: Bill, upper mandible brown, lower purplish-brown, lighter towards the gape; point of gape, 1 inch exactly. Top of head raw umber-brown, with a lighter line over the eye 
from the base of the bill to the top of the auricles. Upper portion of head, neck, back, wing-coverts, primaries, secondaries and tertials, umber-brown, with a raw sienna tint. Rump and tail the same brown with a reddishyellow tint. Chin whitish. Under-parts whitish tinged with raw sienna, deeper on the coverts of the thighs. Under tail-coverts tinged with yellowish-brown. Greater wing-coverts and primaries faintly margined on outer webs and end of feathers. Eleven feathers in tail ; middle feather the longest; tail cuneiform. Irides brown. Length from point of bill to end of tail, $7 \frac{3}{8}$ inches. Tarsi bluish-slate, $1_{1 \frac{1}{16}}$ inches long; toes brownish. Second quill-feather the longest in the wing. The bill is strong, and the form of the head very like a Redwing's; in other respects the form more nearly resembles the aquatic warblers, though somewhat more elongated. Can you help me to identify this species? I have been particular in a description of its manners when first moved, since its disinclination to leave the reed-bed and its very short flight coincide with Gould's description of the ThrushWarbler. Its greater length and deeper colouring are the chief points where agreement is wanting; but perhaps, if his work has a fault, it is in its general too high colouring.

"Since writing the above I am convinced the bird is Acrocephalus turdoides. $\mathrm{Mr}$. Gordon, the Curator of the Dover Museum, is quite satisfied about it. We have compared it with Yarrell, and it answers exactly, with the exception of the length $-7 \frac{3}{8}$ inches, against Yarrell's and Gould's 8 inches, and the colour of the legs, given by both Gould and Yarrell as brown; whereas mine, when fresh, were slaty-blue. My bird's legs having dried, have now turned brown. As to length, Yarrell quotes Latham 
and does not speak from his own observation, and no one can read Gould's letterpress without seeing that he mainly went to Yarrell for his description. On skinning my bird it turned out to be "a perfect ball of fat "- so Gordon described it, and this might perhaps account for its laboured flight, which surprised me."-IV. Oxenden Hammond (St. Alban's Court, Wingham, Kent).

The specimen above described is mounted and grouped with a nest and one egg in the Canterbury Museum, but there are $n$ particulars given with regard to the nest and egg.

\section{AQUATIC WARBLER.}

Acrocephalus aquaticus (J. F. Gmelin).

$$
\text { S.N., i., p. } 953 \text { (1788). }
$$

Mr. J. H. Gurney, jun., was the first to call attention to a specimen of the Aquatic Varbler which had been obtained in this county. He wrote the following particulars to the Zoologist in 1871 :-

"On February 2, 1871, I detected an Aquatic Warbler (Calamodyta aquatica, Latham) among the British birds of the late Dr. Plomley at the Dover Museum, which Mr. C. Gordon, the Curator, informed me had been shot by himself in the vicinity. The date is lost, but I have no suspicion of a mistake."

Supposed Occurrence of Sylvia aquatica in Kent.- "On October 12, while rambling over the Cliffe marshes, near the Thames, I saw a little bird flitting along a reedy ditch, which at first sight I considered to be a SedgeVVarbler. Pursuing it, however, with my glass in hand, I got a very near view of the bird, and was surprised to 
find a broad blackish band on each side of the head, giving it the appearance of having the whole head black in certain attitudes. This, added to the very distinct markings on the upper surface, gave the bird an odd, bunting-like appearance while creeping about the bottom of the reeds; on the wing, however, it was indistinguishable from a Sedge-TVarbler, except, as I fancied, by a warmer and richer colouring. Consulting Bree and Gould I was confirmed in the view I talie, viz., that the bird was the Aquatic Varbler. The distinct, broad, blackish band seems to me to give a clear mark of distinction from the Sedge-Warbler."-Clifton, Cobham Hall, Kent, October 14, 1875 (Zoologist, 1875, p. 4693).

\section{SEDGE-IVARBLER.}

Acrocephalus phragmitis (Bechstein.) Orn. Taschenb., p. 186 (1802).

The Sedge-TVarbler arrives in April, and is to be found in all the reed-beds of the marshes, rivers, ponds and ditches in the county, especially those of Romney Marsh and the Lower Medway. Mr. T. Hepburn says it was " common everywhere amongst the growth on the edges of pools and dykes on the beach at Dungeness." It is plentiful on the Royal Military Canal according to Mr. R. T. Filmer, and Mr. E. F. M. Elms found the "Sedge-Warbler in large numbers among the ditch-reeds at New Romney and Littlestone, incessantly uttering their chiding notes, but (May 18, 1902) seemed as yet to have no eggs." Among the summer arrivals in the neighbourhood of Blackheath, Mr. C. Collingwood gives April 
16, 1854, for the first seen at Burnt-Ash Farm, Kent. Mr. H. Lamb states that "this bird is to be found near the river in places round Maidstone. I have several eggs from Allington Woods, about two miles from the town."

During his bird's-nesting in Rient, in 1875, Dr. A. G. Butler found this species breeding at Murston, and describes the eggs. "On May 29 found a variety mottled like White-throat's eggs; Murston, May 26, I cannot identify this with any other species; the nest was of the usual type." It has also been observed and obtained in various localities, as follows: Bethersden, Captain J. D. Cameron. Summer visitor to the Higham and Malling Valley districts, Rev. C. H. Fielding. It is abundant in the Stourmouth Marshes, G. Dowlier; Nonington and Wingham, W. O. Hammond; Elmstone, Rev. IV. B. Delmar; Walmer, Rev. B. Austen; Folkestone, H. Ullyett; Dover, C. Gordon, Dr. Plomley and G. Gray.

In the report on the immigration of summer residents in the spring of 1905, published in the Bulletin of the B.O.C., 1906, the Sedge-IVarbler arrived on April 22, May 7, 8 and 24, in Kent.

\section{Genus LOCUSTELLA, Kaup.}

\section{GRASSHOPPER WARBLER.}

Locustella navia (Boddaert). Table des Pl. Enl., p. 35, No. 581 (1.783).

Cricket-bird.

The Grasshopper Warbler is far from being a common bird in Kent, and it prefers certain localities in which the old undergrowth of vegetation is most dense. It 
is extremely shy and difficult to see, creeping about as it does in tangled masses of bramble and furze.

Mr. C. Collingwood states that the "earliest one observed among the summer arrivals at Shooter's Hill was on April 17, 1854."

It was seen on the top of Boxley Hills on April 23, 1867.

There is a female in the Maidstone Museum, with the nest and two eggs, which were obtained on May 11, 1882, at Hollingbourne, by Mr. J. Coveney.

On June 5, 1906, the Grasshopper Warbler was heard in the woods at Bilsington, and no doubt had a nest there, but it could not be found.

Mr. R. T. Filmer writes that it is rare: "I usually managed to hear one in the summer, but I have never seen one. The path from the railway bridge towards Orlestone Church is a good place on a nice evening for one to be heard."

In his Ornithology of Kent, 1844, the Rev. J. Pemberton Bartlett says it is "common," and Dr. A. G. Butler found it breeding in Stockbury valley in Kent. It is also mentioned by the Rev. C. H. Fielding as among the summer visitors at Higham and the Malling valley, and Mr. G. Dowlier says it is rare in the Stourmouth district, and adds the following localities in which it has been observed: Nonington, IV. O. Hammond; Dover, C. Gordon and Dr. F. Flomley; Folkestone, H. Ullyett. In the Birds of Rainham, Mr. WV. Prentis mentions "a singuiar variety obtained on June 5, 1869. Back, greenish-brown, with darker markings; breast, greenishyellow, without spots. It was a male, shot while singing."

The late Mr. A. D. Bartlett, in his youth, being an 
ardent egg-collector, made many excursions into Kent for eggs of rare Warblers, and happened to be sitting on the outslirts of a wood between Greenhithe and Dartford, when he caught sight of a Grasshopper Wrarbler come out from the lower part of a large stacli of faggots, and then saw the bird go back. He immediately set to work to remove part of the faggots, but he found that it was necessary to commence at the top of the stack. At last, after much labour, he succeeded in getting the nest and four eggs, to his great delight; but at the same time expecting every moment to be seized by the owner of the stack, he did not stop there to put the faggots back. The subjoined are interesting notes on this bird, by Captain H. W. Hadfield, which appeared in the Zoologist, $1857:-$

"May 6, 1857. In passing through a wood on my return from the village of Pembury, I heard the peculiar but well-known note of this singular little bird, which I was not long in discovering, as it was perched on one of the topmost twigs of a bush, at the distance of 30 yards. The Grasshopper Warbler, we are told, is generally dispersed, and so it may be; nevertheless, it is my belief that not one person in fifty has ever set eyes on it, though possibly they may have heard the notes, which, doubtless, would be taken for those of the Grasshopper or Cricket. But even if occasionally seen (which, from its sliulking habits, is not likely), it would probably, unless in the very act of singing, be taken for a Whitethroat, to which it bears a striking resemblance, particularly when creeping among the bushes. Having shot the bird, and wishing to compare it, I turned over Temmincli's beautiful coloured prints, and might have continued to do so from that time to this without recog- 
nising it, had it not been for the name at the foot of the page, for the artist has made both throat and belly black, whereas those parts are white. The work referred to originally belonged to Yarrell (who had made notes in it, and added an English index), or I could have fancied the prints had been tampered with."

\section{SAVI'S WARBLER.}

Locustella luscinioides (Savi). Nuova Giornale de' Litterati, vii., p. 341 (1824).

The only record of this species having been found in Kent is given by Mr. James Green, in the Zoologist, 1853, who says: "I have now by me the nest and five eggs of Savi's Warbler, which I took at Erith, in Kent, on May 28, 1853."

Mr. J. E. Harting, in his Handbook of British Birds, 1872 , states that "the eggs have also been taken in Essex, Kent and Devonshire."

Professor Newton, in Yarrell's British Birds, 1871-74, remarks that the late Mr. Green records (Zoologist, 1853 , p. 2849 and p. 3945) nests taken at Dagenham and Erith in 1850 and 1853 respectively.

Genus ACCENTOR, Bechstein. HEDGE-SPARROW.

Accentor modularis (Linnæus). S.N., i., p. 329 (1766).

Dicky Dunnocks, Hedge Poker.

The Hedge-Sparrow is very plentiful throughout the county. It is to be found in every garden and hedgerow, where it may be seen all the year round, and, like 
the Robin, is one of our most familiar birds. In severe weather it comes to the home of man, seeking its food up to the door, searching everything that is thrown from the litchen for dainty morsels.

It is one of the earliest breeders, like the Robin. A nest was found at Edenbridge with four eggs on February 4, 1906. Another was observed at Bilsington on April 23, with four eggs in it, but the weather became very severe, and it was deserted after the eggs were hard set. The majority of the nests are not built until the early part of May, one was seen on the 18th, then they became very numerous. Dr. A. G. Butler found nests at Sittingbourne on May 24 and 27, and at Barming on June 8.

The Hedge-Sparrow does not appear to be a migratory species; they do not diminish in numbers during the hardest winters.

Genus MIMUS, Boie. NORTHERN MOCKING-BIRD. Mimus polyglottus (Linnæus). S.N., i., p. 293
(1766).

The only occurrence of this species in Kent is recorded by Mr. W. H. Cordeaux in the Zoologist, 1851, as follows: "About August 19 (1851) a fine specimen of this bird was lilled on a farm near Ashford."

This, like the Migratory Thrush, was no doubt an escaped bird from a vessel or an aviary. 


\section{Family CINCLID $Æ$.}

Genus CINCLUS, Bechstein.

DIPPER.

Cinclus aquaticus, Bechstein. Orn. Taschenb., i., p. 206 (1802).

The Dipper, being one of our most northern residents, rarely makes its appearance on the south-eastern coast. The earliest notice of this bird in Fent is that contained in the Rev. J. Pemberton Bartlett's Omithology of Kent, (Zoologist, 1844), who says it is "very rare," and in the Zoologist, 1850, Dr. F. Plomley notes one "on or near the coast of Dover, January 16, 1850." There are two specimens in the Maidstone Museum labelled Kent, presented by Mr. G. Simmons.

Mr. G. Dowker states that it is a "very rare, accidental visitor, and that Mr. C. Gordon records one from River, near Dover."

The only other occurrence is that communicated to the Zoologist, 1891, by Mr. J. H. Gurney, jun., who states "that between October 29, 1890, and Christmas of the same year a Dipper (Cinclus aquaticus) was shot on the rocks at Ramsgate."

\section{BLACK-BELLIED DIPPER.}

Cinclus cinclus (Linnæus). S.N., i., p. 290 (1766).

On the authority of Mr. G. Dowker, in his Birds of East Kent, 1889, and that of Mr. C. Gordon, one was shot at Folkestone, and is now in the Folkestone Collection. 


\section{Family PANURIDÆ. \\ Genus PANURUS, Koch.}

\section{BEARDED TITAIOUSE.}
Pamurus biarmicus (Limnæus). S.N., i., p. 342 (1766).

The occurrences of the Bearded Titmouse in Kent at the present day are extremely rare, and one may say accidental, compared with former times, when the large, over-grown wild marshes which existed were unreclaimed.

In Yarrell's British Birds (1843) it is mentioned that "eastward from London the Bearded Tit inhabits the various reed-beds on the banks of the 'l'hames both in Kent and Essex."

In his Ornithology of Kent (Zoologist, 184t), the Rev. $J$. Pemberton Bartlett states it is "occasionally found in Romney Marsh." Norris, in his British Birds, also gives between Erith and London, and the Kentish coast of the River Thames.

Professor Newton, in the fourth edition of Farrell's British Birds (1871-74), says: "A few may still breed, as heretofore, in East Suffolk, in Essex, Kent, or even Surrey, but there is no satisfactory evidence that such is the case."

Mr. G. Dowker, in his Birds of East Kent, nentions one shot some years ago at Monckton, by Mr. WT. Austen ; and the Rev. B. Austen gives Walmer as a locality. There is a specimen in the Exeter Muesum labelled Fent, the bequest of the Rev. Bower-Scott, and a pair of these birds are contained in the collection of Kentish birds in the Maidstone Museum from Mr. G. Simmons. 
-Dr. A. G. Butler, in his British Birds' Eggs, 1886, states: "I have also seen a nest, but without eggs, at Kemsley, on the Kentish coast. The nest was placed upon a small island of partly decayed reeds (trodden down by Moorhens and Duclis) near the centre of a large pond. It is therefore clear that the county of Tient is not yet wholly deserted as a breeding-place by this species."

Mr. W. Prentis records, in his Birds of Rainham (1894), "three that were shot in a reed-bed on the banks of the Medway in the winter of 1865 , near Maidstone."

\section{Family PARID正.}

Genus ACREDULA, Koch.

WHITE-HEADED LONG-TAILED TITIIOUSE.

Acredula caudata (Limmaus). S.N., i., p. 342 (1766).

The only recorded example of this species having been obtained in Kent is upon the authorities of Messrs. C. Gordon and G. Dowker, in the latter's Birds of East fient, 1889. The specimen was killed near Dover Castle. It was, or now is, in the collection of Mr. WV. Prentis.

\section{BRITISH LONG-TAILED TITMOUSE.}

Acredula rosea (Blyth). White's Nat. Hist. Selborne, p. 111, note, 1836.

Bottle Tit.

The British Long-tailed Titmouse is generally distributed over the county. These curious little titmice may be seen in the latter part of the summer, and 
through the winter until spring in small families of from five to eight in number, passing through, and searching all the hedges and trees in their rambles for insects. In the spring they are only to be seen in pairs, and at this period it is easy to note the locality for the nest. One nest was found with young in it, in a wood near Orlestone, on April 30, 1903, and another on May 8, 1906, near Orlestone. It was fixed in a white-thorn bush about five feet from the ground, and of the usual type, of green moss covered with small flakes of white lichen. It is a moderately common resident at Stourmouth, but not all the winter, G. Dowker. It has been observed in all the following localities: Nonington, IV. O. Hammond; Dover, C. Gordon, G. Gray and Dr. Plomley; Folkestone, H. Ullyett; Elmstone, Rev. IV. B. Delmar; Walmer, Rev. B. Austen; Higham and Malling valley, Rev. C. H. Fielding; Maidstone, I have noticed small flocks often in winter, H. Lamb; Bethersden, Captain J. D. Cameron.

From October 11, 1905, many small flocks were noted in Romney Marsh below Ruckinge and the Royal Military Canal throughout the winter.

\section{Genus PARUS, Limnæus.}

\section{GREAT TITMOUSE.}

Parus major, Limmæus. S.N., i., p. 341 (1766).

$$
\text { Ox-eye and Joe Ben. }
$$

Although the Great Titmouse is generally distributed over the county of Kent and a resident, it is nowhere found in numbers, being rather, if anything, a solitary bird, or only found in pairs during the breeding season. 
This Titmouse is a great mimic, and many persons have mistalien its voice for other birds. An instance is recorded of one observed at Boxley, in Kent, which was heard to imitate the alarm-note of the Flycatcher; another is given by Captain $H$. IV. Hadfield in the Zoologist, 1857, of it imitating a WVoodpecker or Nuthatch on the branch of a tree; lie says: "When walling this afternoon (January 1, 1857) in Summerhill Park, Tonbridge, my son directed my attention to a sharp tapping sound proceeding apparently from one of the lofty oalis with which this beautiful domain abounds, and on going with cautious steps to the foot of one of them, I perceived, not a Woodpecker or a Nuthatch, as I had at first imagined it might be, but a Tomtit, clinging to one of the topmost branches, whether hollow or not I had no means of ascertaining, but, judging from the loud vibrating sounds, I should conclude it was. That the little creature was endeavouring, after the manner of the Woodpecker, to rouse and bring to the surface its insect food, there can, I think, be little reason to doubt; but that so diminutive a bird, or, rather, one with so small a bill, should have the power of making so far-sounding a noise is, I think, somewhat remarkable."

It nests more frequently in very old timbered woods, especially in old pollard willow stumps, and in many cases the nest is not easy to procure.

The subjoined strange particulars respecting a supposed nest of this bird appeared in the Zoologist, 1870, and will be read, no doubt, cum grano salis :-

Bird's Nest in Solid Wood.- " A curious discovery has recently been made at Chislehurst, in Kent. A large elm tree in the churchyard was cut down, and a bird's nest with seven eggs was found completely embedded, 
and having at least nine inches of solid wood grown over it, without any trace of an outlet. The eggs are as perfect as when first laid, and are supposed to be those of the Great Titmouse (Parus major)."-J. E. Anderson, April 22, 1870.

The Great 'Tit is contained in Boys' Birds of Sandwich, 1792. It is plentiful round Maidstone, and breeds on Boxley Hills, H. Lamb; and is found in the districts of Bethersden, Captain J. D. Cameron; Orlestone, R. T. Filmer; Malling Valley, Rev. C. H. Fielding. A common resident at Stourmonth, G. Dowker. In Pennant's British Zoology, 1812, it is mentioned that "Mr. Lewin records the circumstance of one having been killed at Faversham, which had both mandibles singularly elongated or crossed in the manner of the Crossbill."

\section{BRITISH COAL TITMOUSE.}

Parus britannicus, Sharpe and Dresser. Ann. and Mag. Nat. Hist. (4), viii., p. 437 (1871).

The British Coal Titmouse is a resident in Kent, but by no means abundant anywhere. They may be seen more often in the autumn, winter and spring, when searching for food, in nearly all the wooded districts in the county, especially among the old pine and oak trees.

In the Orlestone district it is scarce. On March 12, 1902, it was obtained in Burnt Oak Wood, and also on March 13 it was found in Clerksland Wood, again on April 17; and on October 28, 1905, it was also seen near Mersham, at Bilsington, and in the woods near Ruckinge. The general distribution in Kent may be culled from the following observers: Bethersden, Captain J. D. 
Cameron. It is not uncommon in the old fir trees at Thornhills, near Maidstone, and in the yews on Boxley Hills. It was always to be found in the large fir trees at Mereworth, and in Broadwater forest, near Tunbridge Wells. The Rev. J. Pemberton Bartlett, in his Ornithology of Kent, 1844, states it is "not common," and Mr. G. Dowker says it is a "moderately common resident at Stourmouth." It is also included in the Birds of the Malling Valley, by the Rev. C. H. Fielding.

In his British Birds' Eggs, 1886, Dr. A. G. Butler says: "I have received the nest of this species from Kent as late as the beginning of June, it was taken out of a decayed fruit tree, the heart of which it occupied, and was at no great distance from the ground."

\section{MARSH-TITMOUSE.}

Parus palustris, Linnæus. S.N., i., p. 341 (1766).

'The Marsh-Titmouse is more numerous as a species than either of the former, viz., the Great Titmouse and Coal Titmouse, and less plentiful than the Blue Titmouse, next to be mentioned.

Although the name Marsh-'Titmouse has been applied to this species, it is more often found in the smaller woods of Kent than in the low-lying country. It has been obtained more commonly in all the wooded districts from Ashford to Orlestone and Ruckinge, and the hillsides overlooking Romney Marsh. These woods are cut down every few years, and the Marsh-Tit makes a home of the smaller growth, which at the end of two of three years forms a thick mass in which these small birds can conceal themselves. 
The Rev. J. Pemberton Bartlett, in his Ornithology of Fent, says it is "common." It has been obtained at Boxley, generally at the foot of the hills, but is not plentiful there, and it was seen in Mr. Lushington's woods in March, 1868. It is rare in the Stourmouth district, according to Mr. G. Dowker, and is noted by the Rev. C. H. Fielding in the Birds of the Malling Valley, and at Bethersden by Captain J. D. Cameron.

The Marsh-Tit is among the Birds Observed at Rainham (1865), by Mr. W. H. Power, who says : "I noticed several of these Tits during September. This species is far more common than the Coal Tit, and next to the Blue 'Tit is the most common of our local Parida."

While insect-collecting in Mereworth WValk, a MarshTit was seen to come out from under a bank which the heather overhung and had almost hidden. On careful examination a beautiful nest of this bird was found formed of moss and lined with feathers, fixed in the old roots of the heather in the bank; it contained six eggs.

\section{BLUE TITMOUSE.}

Parus caruleus, Limnæus. S.N., i., p. 341 (1766). Tomtit.

The Blue Tit is one of the best known and most familiar of our Titmice, and the only one which makes itself at home around the habitation of man. It is plentifully distributed all over the county, not only in the woods, but bedgerows and gardens, and it will take long flights to isolated trees in search of food, and its lively, mouse-like habits are always amusing. In severe weather they will often come down and snatch a morsel of soft. food thrown out to the fowls and other birds. 
On October 24, 1905, the Blue Tit was first observed feeding in the tall reeds of a sewer on the roadside, not far from Brenzett, which attracted attention on account of the strange position, away from all the wooded country. Again, on November 8 one was seen in the reeds not far from Snave. On the night of November 15 snow fell, and on the morning of the 16 th several Blue Tits were noticed feeding close down to the waier's edge among the reeds in a large sewer on the road to Newchurch; and on the 17th they were still in the same reed-bed, evidently searching for larvæ, or minute insects which climb the reed-stems. In these places they continued all through the winter.

Mr. C. A. Witchell, of Eltham, Kent, gives an interesting account of the variation of habits in the Blue Tit, in the Zoologist, 1896, as follows: "Early in February last, near New Eltham, and about 8 a.m., I noticed two Blue Tits (Parus caruleus) flying from tree to tree along the road in the direction of my walk. The leading bird, which appeared to be a male, frequently uttered callnotes; the other, which I presumed to be a female, was comparatively silent. The leading bird, after flying for a little distance in the usual jerky manner of the species, would suddenly extend his wings and hold them motionless, so that he might be said to soar along, in which position the upward curving of the long feathers was clearly visible. Sometimes he travelled in this way for only a few feet, sometimes for as much as 10 yards. Once when he was sailing along a male House-Sparrow flew at him and made three or four attempts to peck him in the air; but the Tit with much agility aroided the attack, and he then perched in a chestnut tree, closely followed by the Sparrow; but the latter, though not 
more than a foot distant from the Tit, took no further notice of him. On the following morning, near the same place, I saw two Blue Tits, and one of them came from a position about half-way up an elm tree, and descended in a graceful swoop, on motionless wings, to a lamp-post on the other side of the road. On no other occasion have I seen any Titmouse exhibit this peculiar gliding flight, which in this case was presumably intended for the purpose of display; but if such behaviour is likely to incite the attacks of other species, it probably will never become prevalent in the Tit. It is, of course, with some other birds habitual." Continuing his remarlis in the Zoologist, 1897, he says: "In the Zoologist for 1896 I recorded the unusual habit of a Blue Tit in soaring on motionless wings from perch to perch. I afterwards saw this bird often, and this year (1897) it exhibited exactly the same behaviour. On one occasion it rose from the top of an oak, and then sailed along, in the manner of a Tree-Pipit, to the top of a lower tree. The best 'sail' it executed was when passing over a road to the lamp-post in which its nest was afterwards built; it was going against the wind, and seemed to creep along the air in a charming manner, and was closely followed by another 'Tit, to which it had been addressing ardent call-notes. The Blue Tits here nest in the lamp-posts. The lamplighters tell me they all rear their young, and I lately heard the cry of a young one from the top of a lamp-post, and several others, just able to fly, were around the spot. An old Tit occupies about a minute in descending and reascending a lamp-post, and probably it proceeds by rapidly hopping from side to side; there is not enough space for the spreading of its wings."

This summer, 1906, a pair of Blue 'Tits took possession 
of a narrow crevice which was just between the front wall and the chimney stack of a cottage at Ruckinge. This crevice passed in close to the fire-place, about 4 feet from the ground, so that they would receive the warmth from the stove. In this same crevice they reared two broods. Nothing larger than themselves could get in, and no one could touch the nest without pulling out the brickwork.

\section{CRESTED TITMOUSE.}

Parus cristatus, Linnæus. S.N., i., p. 340 (1766).

The first notice of this bird in Kent is to be found in Mr. J. E. Harting's Birds of Middlesex, 1866, who says: "One shot a few years ago at Blackheath, by Mr. Engleheart, in his garden; this is the only instance that has come to my linowledge of the Crested Tit having been found so far south in England." In his Handbook, 187.2, this bird is again mentioned under Blackheath, Kent, but it is omitted from his last edition of that work (1901).

The only other reference to the Crested Tit in Kent is that given by Mr. G. Dowker in his Birds of East Iient, 1889, in which he mentions one in the Canterbury Museum, apparently obtained from the neighbourhood.

Family SITTIDÆ.

Genus SITTA, Linnæus. NUTHATCH.

Sitta casia, Wolf. Taschenb. deutsch. Vög., i., p. 128 (1810).

The Nuthatch is not plentiful, although generally distributed over the whole of Kent in suitable situations.

This bird restricts its haunts to the larger and older 
forests, woods and orchards, and in such places it may be found nearly always in pairs, never, or very rarely, taling to the more open districts. It used to nest in the large trees in Mereworth Walk, and it has been observed in Broadwater Forest, near Tumbridge Wells. According to Mr. H. Lamb, it is found in the old orchards near Maidstone, and Mr. H. Elgar obtained specimens at West Farleigh. Captain J. D. Cameron adds it to the birds of Bethersden, and the Rev. C. H. Fielding includes it among the resident birds of the Malling Valley. In the Orlestone district it is rare, according to $M r . R$. T. Filmer. It usually visits the cherry orchards at Ham Street during the winter. A pair have nested in a wild cherry-tree in Bourne Wood for several years.

'The following notes are taken from the Zoologist, 1857, written by Captain H. W. Hadfield, of Tonbridge: April 8, 1857. "Descried a female Nuthatch in a lofty oak tree; it was seemingly engaged in enlarging a hole, or opening, in one of the branches, possibly with a view to constructing a nest, for so intent was it upon the work, that it allowed me not only to approach the tree, but to explode two or three percussion caps before I could discharge the gun, and when it did take wing I was not long in discovering it again, being attracted to the spot by the loud tapping sound it made with its bill, which might probably have been heard at the distance of fifty yards or more. April 9: I observed two Nuthatches fly across the road and alight suddenly on some high trees; I followed them up, and shot one, which proved to be a handsome male bird; subsequently shooting the female. The male, although a stouter and heavier bird than the female, does not much exceed it in length, although the bill is stronger and about a tenth 
of an inch longer; the plumage, however, is far more brilliant, the sides and feathers beneath the wing, as well as the under tail-coverts, being of a bright chestnut or reddish-brown, whereas in the female these parts are much paler, indeed, many shades lighter."

Captain Boyd Alexander, in his Notes on the Birds of Kent (Zoologist, 1896), remarks: "Compared with formel" years, the Nuthatches bred this season very sparingly. On the other hand, in the Tunbridge Wells district a wonderful increase took place in their numbers. After the autumn moult the plumage of the male Nuthatch is remarkably handsome, the breast being a most delicate apricot, while the slate-blue of the upper parts is very intense in colouring. Just now these birds are extremely restless; most of their time is taken up in putting by a winter store of food, and this especially consists of hazel-nuts, which are plentiful this year."

\section{Family TROGLODYTIDÆ.}

\section{Genus TROGLODYTES, Vieillot.}

\section{WREN.}

Troglodytes parrulus, Koch. Syst. d. Gaier. Zool., p. 161 (1816).

This very active and interesting little bird is abundant throughout the county of Kent. In early spring and winter its voice may be heard, except during a short period of its nesting season. It has been heard singing on December 11, near Maidstone, and in the neighbourhood of Orlestone on fine, sunny days in mid-winter. Its habit of keeping to the old overgrown hedges and 
thickets is a great protection, and in such places it may be seen searching, mouse-like, for its insect food.

In some instances the nests are very difficult to find, and in others they are most conspicuous. A nest was found on the wood-side at Ruckinge, built in a stunted elm bush on a level with the face of the passers-by, in fact, one could look into the hole of it and see the eggs; another was close down to the ground among a lot of rubbish and leaves, and if it had not been for the bird flying out it might have been passed over and over again. A nest was found by Mr. H. Lamb, in 1875, not far from Maidstone; it was placed in the top of an arch on the South-Eastem Railway, within a foot of the rails, but the birds, after completing the nest, deserted it.

\section{Family MOTACILLIDÆ.}

\section{Genus MOTACILLA, Linnæus.}

\section{WHITE WAGTAIT.}

Motacilla alba, Linnæus. S.N., ,i., p. 331 (1766).

The White Wagtail, although frequently met with along the coast of Tient during the summer and autumn, is not so abundant as the Pied Wagtail, and no doubt it is often overloolsed.

Dr. F. Plomley, writing to the Zoologist in 1846, says: "My attention having been drawn, since the publication of Mr. Yarrell's Supplement, to the White Wagtail (Motacilla alba), I find they are very common in this part of of Kent (Lydd), as I seldom pass a day without seeing several pairs, though I have not yet been able to get their eggs." 
There is no doubt that the nest and eggs of the two Pied Wagtails are so alike that it requires careful observation of the adult birds to identify the eggs.

\section{PIED WAGTAIL.}

Motacilla lugubris, Temminck. Man. d'Orn., i., p. 2.53 (1820).

\section{Dishwasher, Peggy Dishwasher ; White Water Wagtail, Boys, 1792.}

The Pied Wagtail is one of the most abundant of the several species of Wagtails throughout the county, and it may be seen generally in pairs near all our large lakes, ponds, ditches, and country roads in the vicinity of water.

The curious nesting habits of this bird are very variable, and it is uncertain where the nest is to be found, for many are placed in the least likely situations one would look for it. One was found in the ivy on the front of a house close to a window overlooking the lawn, a long way from any water.

Mr. T. Hepburn, in his notes on this species at Dungeness, says it is "common near the fishermen's or coastguards' cottages and farm buildings. Rather a favourite nesting place for them was amongst the stacks of fish-boxes near the coast."

A nest was found by Mr. H. Lamb in a heap of stones at Barming.

This Wagtail, unlike its near ally the White Wagtail, is distributed far inland, and not confined to the seacoast, or the large rivers. 


\section{GREY WAGTAIJ. \\ Motacilla melanope, Pallas. Reise Russ. Riechs., iii., p. 696 (1776). \\ Grey Water Wagtail, Boys, 1792.}

From the particulars which have been collected respecting the Grey Wagtail in Kent, it will be seen that this species is far more plentiful than at first supposed, and it may be considered as a permanent resident. Throughout the districts risited a pair or an odd bird has been observed in every month of the year.

In 18tt, the Rev. J. Pemberton Bartlett states that it is " common."

Mr. Tarrell in his British Birds, 1843-56, states that "in the comnties around London the Grey Wagtail is a winter visitor, but Mr. E. Blyth has recorded that he once observed a pair of them upon Penge Common in Kent at the end of May, that evidently had a nest in the neighbourhood, though he was unsuccessful in his repeated endearour to find it."

In 1865 Mr. W. H. Power, in his Birds Observed at Rainham, says the Grey Wagtail "appears on the marshes early in the autumn on its migration southwards. The first note I have of its appearance this year (1865) is on September 7. It does not stay in any numbers, more often paying only a flying visit." And Mr. F. D. Power "observed it on the Rainham Marshes on September 8 , 1868."

Lord Clifton, in writing to the Zoologist, 1869, remarks : "Mr. Power, in the Zoologist for January, says that the Grey Wagtail appeared on the Rainham Marshes on 
September 8; on that very day I saw one at Cobham, the only one I ever saw there."

The Grey Wagtail is, according to Mr. D. T. Button, " common all the winter, from November to March, in the watercress-beds at Springhead, near Gravesend; I have obtained many fine examples from there." On August 6, 1877, Mr. H. Lamb met with this species on the cricket ground at Yalding; and in the winter of 1878, in November and December, he again found it in the Loose Valley, near Maidstone. In the winter of 1878-79, specimens were obtained in Clare Park, East Malling, Kent. A male in the Maidstone Museum was obtained at Hollingbourne in January, 1881. Several were seen by Mr. H. Elgar between Aylesford and Snodland on November 15, 1893, and one at Aylesford on September 22, 1894.

Dr. A. G. Butler, in his British Birds' Eggs, 1886, says: "The fact of its occurrence in Kent, though already recorded, is confirmed by a nest which I obtained at Kemsley, in Kent, on May 16, 1885; it was built on the ground behind a clod of earth in a fallow field, and was discovered by a boy whilst ploughing; this boy took me to the spot, and the bird flew off the nest as we approached. The nest is formed of root fibre mixed with coarse grasses, cow- and horse-hair, and is lined with black horse-hair, white cow-hair and wool ; it originally contained four eggs of the ordinary type, but one was broken by the fall of a piece of earth into the nest as it was being removed; they are slightly larger than the eggs of the Pied Wagtail, and are rather closely mottled with pale yellowish-brown, which gives them a stone-grey tint."

On July 24 , 1906, Mr. Bartlett found many Grey Wagtails in the large sewers and Royal Military Canal between Dymchurch and New Romney 


\section{BLUE-HEADED YELLOW WAGTAIL.}

\section{Motacilla flava, Limnæus. S.N., i., p. 331 (1766).}

This species is certainly rare compared with the other Wagtails, and it is not so generally distributed in Kent, being restricted in its habits to the seaboard and large salt-marshes.

Morris, in his British Birds, mentions a pair that were shot at Dover, near the harbour, in July, 1851. According to Professor Newton, in Yarrell's British Birds, " they have generally occurred on or near the coast of the southwestern, southern, or eastern counties, Kent, \&c., mostly in the months of April, May, or June, and several times in pairs."

Dr. A. G. Butler "obtained the nest and eggs of this species from the saltings by the creek at Kemsley, near Sheppey, in Kent, in the early part of June, 1885. The bird was known to the boys by the popular name of 'Whip Jack.' The nest is slighter than those of the three other species which I obtained at Kemsley in May; it is formed of fine fibrous roots and coarse grasses, and is thickly lined with black horse-hair. It contains six eggs of a pale yellowish-brown colour, rather yellower than those of the Yellow Wagtail (M. raii), and not unlike some eggs of the Sedge-Warbler, excepting that they are slightly larger and have a more polished surface. I may mention that I have seen this species of Wagtail within a mile or two of Kemsley, and at the same time of year." 
GREY-HEADED YELLOW WAGTAIL.

Motacilla viridis (Gmelin). S.N., i., p. 962 (1788).

Mr. G. Dowler, in his Birds of East Kent, states that "Mr. W. Oxenden Hammond writes to me, May 1, 1889, that the Grey-headed Wagtail has just been killed between Deal and Dover, by striking itself against the telegraph wires."

Under the name of Grey-headed Wagtails (Motacilla borealis), a pair, with their nest, were taken by $\mathrm{Mr}$. Bristow, of St. Leonards-on-Sea, from the marsh between Rye and Lydd on June 20, 1906, probably the first recorded instance of the breeding of this bird in Great Britain (Bulletin of the B.O.C., vol. xix., p. 23, 1906).

\section{YELLOW WAGTAIL.}

Motacilla raii (Bonaparte). Comp. List B. Eur. and N. Am., p. 18 (1838).

\section{Yellow Water Wagtail, Boys, 1792; Yellow Dishwasher.}

The Yellow Wagtail, or, more properly speaking, Ray's Wagtail, to distinguish it from the other more or less yellow species, is one of our most familiar birds, next to the Pied Wagtail.

This species is not confined to the sea-coast, but finds its way far inland to breed, and is thoroughly distributed over the whole of Kent during the summer, especially near large lakes, ponds and streams. It is very pretty to see a pair of these canary-coloured birds running about and feeding on the road, and they may be seen acting the Flycatcher, by darting up in the air for a fly. Among 
the birds of Rainbam, Mr. F. D. Power tells us the Yellow Magtail is "numerous up to the middle of September on the marshes, they then rapidly become scarce: last seen on October 6, 1868." It used to breed in the Lower Rainham marshes. Mr. H. Lamb says that he often saw it near Maidstone in the summer, and in the summer of 1877 one was hovering about some clover tops. Mr. E. Bartlett also obtained this species at Maidstone, May 12, 1888, and $\mathrm{Mr}$. H. Kennard procured it on August 16, 1888. The nest and eggs were obtained by the Rev. H. Watson, at Boughton Malberbe, in June, 1889. Dr. R. B. Sharpe procured specimens in May, August and September at Plumstead, and in May, July, August and September in Romney Marsh. Captain J. D. Cameron includes it in his birds of Bethersden, and it is a summer resident in the Malling Valley, according to the Rev. C. H. Fielding.

Dr. A. G. Butler says: "A nest of this bird was brought to me on May 16, 1885, found at Kemsley, in Kent, in the bank of a pit, partly filled with water, amongst rank herbage. This Yellow Wagtail is by no means an uncommon species in the neighbourhood of Sheppey ; I have seen it every year, either in the briclifields of Murston or Kemsley." Mr. S. A. Davies, in his Omithological Notes from East Kent, adds: "On September 29 (1895) there were vast numbers of Yellow Wagtails, with a fair admixture of Pied Wagtails, all along the shore in the direction of Deal." In Captain Boyd Alexander's ornithological notes from Rye he states that on "August 27, 1896, light north-westerly wind. The Yellow Wagtails are edging eastwards. Towards evening large numbers had concentrated around Dungeness, prior, no doubt, to crossing the Channel." In his notes on the 
birds on the beach at Dungeness, 1900, Mr. T. Hepburn found the Yellow Wagtail "a common bird on the marshland. May 10: Found a nest in an empty iron shell-case with a full clutch of fresh eggs in it. July 16 to 21 : Plenty of these birds still about."

In the report on the immigration of summer residents in the Bulletin of the B.O.C. for the spring of 1905, the arrival of the Yellow Wagtail in Kent is April 21.

\section{Genus ANTHUS, Bechstein.}

\section{MEADOW-PIPIT.}

Anthus pratensis (Linnæus). S.N., i., p. 287 (1766). Less Field Lark, Boys, 1792 ; Titlark.

The Meadow Pipit, commonly called the Titlark, is usually found in small flocks in the autumn and winter throughout the county, separating into pairs in the spring for the breeding season. They prefer low-lying meadows and open commons, and are very abundant in the marshes along the Thames and Medway. In the Orlestone district Mr. R. T. Filmer says they seem to delight in sitting on the telegraph wires along the railway cutting, and building their nests on the grassy slopes. In the pastures of Romney Marsh they may be found all the year round.

On the beach at Dungeness, in 1900, Mr. T. Hepburn states that it is "about the commonest bird on the beach and surrounding land, laying wherever there is a 'tot' of grass big enough for it to make its nest in. May 10 to 14 : Found nests with eggs in all stages of incubation, and with young birds already fairly well fledged." 
In the neighbourhood of New Romney and Littlestone Mr. E. F. M. Elmes says: "In the first clump of coarse grass that I came to on Great Stone Point 1 found a nest containing four newly hatched Meadow-Pipits. A nest of four eggs, well concealed in a dense tuft of coarse grass. My attention was drawn to it by the grasses being parted from one another, the result of the parent birds' continual ingress and egress to and from the nest itself."

\section{RED-THROATED PIPIT.}

Anthus cervinus (Pallas). Zoogr. Rosso-As., i., p. 511 (1811).

The only recorded specimen of this species is the one obtained at Rainham by the late Mr. Walter Prentis, who wrote to the Zoologist in 1884 as follows:-

Red-throated Pipit in Kent.- " Having read Mr. J. H. Gurney's note (p. 192) on the occurrence of the Redthroated Pipit, Anthus cervinus, at Brighton, I hare pleasure in sending you word of another specimen answering the description, which I obtained here (Rainham) in the month of April, 1880. I shot the bird myself, one fine day, while it was feeding and singing along the fresh turned-up furrows behind my plough, and not identifying it, sent it to Dover to be preserved for a bright example of the Neadow Pipit."

This specimen was eventually identified at the British Mruseum by Dr. R. B. Sharpe. 


\section{TREE-PIPIT.}

Anthus trivialis (Linnæus). S.N., i., p. 288 (1766). Titlark, Boys, 1792.

The Tree-Pipit is not a common species in Kent. Soon after its arrival in the spring it becomes sparingly distributed, generally selecting most of the railway cuttings and steep grassy banks and billsides for its breeding grounds. In these situations it may be seen, and heard, rising in the air, and floating down again with upraised wings, singing as it descends.

In some seasons, Mr. R. T. Filmer writes, it is quite common about the railway at Orlestone, and in others quite the reverse, especially during 1904-6 very few had been seen.

On April 17, 1902, the first Tree-Pipit was seen at Orlestone, and one was obtained on April 23. According to the Rev. C. H. Fielding it is a summer resident in the Malling valley and at Higham. It is included in the birds of Bethersden by Captain J. D. Cameron, and Mr. $\mathrm{H}$. Lamb says it is plentiful near Maidstone during the breeding season, where Mr. E. Bartlett found it breeding. In his Birds of Rainham Mr. W. Prentis says: "The Tree-Pipit is one of our summer arrivals ; comes in MidApril, frequents trees in the low coppices; whence circling upwards and returning to the same perch, sings in the air most sweet and delightful notes. When making hay near the woods the Tree-Pipit flies from heap to heap, keeping the haymakers company, singing all the while its pleasing song."

In the report on the immigration of summer residents in the spring of 1905, published in the Bulletin of the B.O.C., the first Tree-Pipit arrived in Kent on April 13. 
Mr. R. T. Filmer relates rather a curious instance of the intelligence of the Tree-Pipit. One day while sitting down to rest on the bank in the railway cutting, a TreePipit flew across the line from the opposite side, and hopped on to his boot, and appeared in distress; it then flew back again to its nest. Thinking this was somewhat strange, he crossed over, and found a Common Snake devouring one of the newly hatched Pipits; it had already eaten one, leaving only two young ones in the nest. $\mathrm{He}$ dispatched the snake, to the relief of the Tree-Pipit.

\section{RICHARD'S PIPIT.}

Anthus richardi, Vieillot. Nouv. Dict. d'Hist.

$$
\text { Nat., xxvi., p. } 491 \text { (1818). }
$$

In his Ornithology of Kent, in the Zoologist, 1844, the Rev. J. Pemberton-Bartlett states that it "has been shot in Kent," but he does not give a single instance.

Richard's Pipit may be considered an occasional visitor to the county, and few records of its occurrence are to hand.

Mr. Charles Gordon, of Dover, writing to the Zoologist, 1868, says: "On October 21 (1868) I shot a most superb specimen of Richard's Pipit (Anthus richardi) in a cornfield in the environs of Dover. It attracted my attention by its loud call. This specimen is in good condition, having just completed its moult. Its length is $7 \frac{3}{4}$ inches, and its weight $1 \frac{1}{2}$ ounces. On dissection the bird proved to be a male."

Mr. W. Oxenden Hammond, of Wingham, in Kent, states: "I obtained a specimen of Richard's Pipit about the middle of November last (1889). It was caught by 
a bird-catcher near Dover, but in pulling the net over, one of the rods struck and killed the bird." There are three specimens in the Canterbury Museum, all labelled Dover, without any further details.

\section{ROCK-PIPIT.}

Anthus obscurus (Latham). Ind. Orn., ii., p. 494 (1790).

Shore Lark, Dusky Lark.

In the fourth edition of Yarrell's British Birds Professor Newton says: "Latham had priority in publishing a scientific name for this species. He says he saw it first in the Leman Collection, but the example he describes was obtained from Lewin, who found it in the Kentish marshes and himself figured the species as the Dusky Lark in the following year (1791)."

The Rev. J. Pemberton Bartlett, in his Oinithology of Kent, 1844, calls this bird the Shore Lark (Anthus aquaticus), and states that it is "not common."

Among the Birds Observed at Rainham, by Mr. W. H. Power, he includes the Rock-Pipit, which he says "appeared this season on October 7, 1865. It is a constant winter visitant, and although inferior in numbers to the Meadow Pipit, is yet tolerably common." And Mr. F. D. Power adds: "September 24, 1868: One seen. Numerous on the saltings by October 2. A common species here in winter." This is also confirmed by Mr. W. Prentis in his Birds of Rainham, 1894. 


\section{VINOUS PIPIT.}

Anthus rupestris, Nilsson. Om. Suec., i., p. 245, t. 9 (1817).

Professor Newton, in the fourth edition of Yarrell's British Birds, unites this bird with the Rock-Pipit; at the same time he says " that examples generally present a rufous or vinous colouring on the breast, inducing some ornithologists to regard them as forming a distinct species. From either of the species last mentioned (Anthus pratensis and A. spipoletta) A. rupestris can be readily distinguished by having the patches at the end of its outer tail-feathers not white, but pale greyishbrown, just as in our own Rock-Pipit."

The only reference to the occurrence of this supposed species in Kent is contained in the Birds of Rainham, 1894, by Mr. W. Prentis, who writes: "I once had the pleasure of meeting with the Vinous Pipit (Anthus rupestris) one rough March, the wind blowing for several days from the east. The marsh was full of Rock-Pipits. I observed a strange-looking variety with a reddish-brown breast, sitting upon a barway; its note, on being disturbed, was very different from the Rock-Pipit's."

\section{F'amily ORIOLIDÆ.}

Genus ORIOLUS, Linnæus.

\section{GOLDEN ORIOLE.}

Oriolus galbula, Linnæus. S.N., i., p. 160 (1766).

The Golden Oriole is almost an annual visitor to the county of Kent, and subjoined is a full account of all, as far as possible, of those that have come under the 
observations of ornithologists. The attention of naturalists was drawn for the first time to this beautiful bird in Kient by the Rev. J. Pemberton Bartlett in his Ornithology of Kent, published in the Zoologist, 1844, who stated that "one of these brilliant birds was shot at Sandwich." Upon seeing this Mr. E. H. M. Sladen wrote to the Zoologist, 1844, as follows:-

"You solicit notes of the occurrence of rarieties in Britain. I heard of the specimen of the Golden Oriole recorded by $\mathrm{Mr}$. Bartlett as shot at Sandwich, and last year I rescued another from the dust of a cottage shelf in the village of Ripple, near Walmer. It had been given to a child by a gentleman's servant, but I was unable to trace its history any further, in consequence of the servant having accompanied his master into Scotland. The plumage was much soiled, but on being placed in the hands of Mr. Leadbeater and cleaned the bird turned out a fine male specimen, I allude particularly to this bird from having been told by a friend in Kent, who gave me the authority of the Curator of the Museum, Dover, for his statement, that the Golden Oriole had a nest in the same neighbourhood (the Oxney plantation, by Kingsdown) two or three seasons ago. I have not had an opportunity of making enquiries, but perhaps some Kentish ornithologist may be able to furnish information on the subject."

On the Nesting of the Golden Oriole in Fent.- "Having made enquiries about the nidification of the Oriolus galbula in East Kent, mentioned by Mr. Sladen (Zoologist, 1844, 762), I am enabled to send the following notice of the occurrence, which may prove interesting to some of the readers of the Zoologist. In the month of June, 1836, a nest built by a pair of these beautiful birds was 
discovered in an ash plantation near the village of Ord. The nest, which consisted of fibrous roots, was attached to two upright stems of ash, around which the fibres were carefully twisted. The entire structure, however, was so thin that when discovered the young birds could be seen through the bottom of the nest. The young ones were taken every care of, but did not long survive their captivity. In the summer of 1831 several young Orioles were shot in the neighbourhood; occasional visitors had been seen in that locality for some years previously. The Golden Oriole is common in several parts of Europe, and particularly in France, from whence I imagine those come which visit Kent. They are, I believe, supposed to pass the winter in Africa. The female is extremely attentive to her young, fearing no enemy in their defence, and permitting herself to be taken in the nest with them. In those countries where they regularly breed the nest of the Oriole is generally suspended from the bough of a tree, and not fixed between upright boughs, as in the case above described." -J. Pemberton Bartlett, Kingston, near Canterbury, December, 1844 (Zoologist, 1845, p. 825).

In the Zoologist, 1849, Mr. J. B. Ellman states that "two specimens, male and female, of this rare and beautiful bird were obtained near Elmstone last week (May), together with their nest (of very rare occurrence in this country), which was suspended from the extreme end of the top branch of an oak tree, and composed entirely of wool carefully bound with dried grass; it contained three eggs of a pure white mottled with black. The note of the male bird precisely resembles the whistling of the common parrot, and is very powerful."

Occurrence of the Golden Oriole at Elmstone.- "I send 
you the following extract from a letter of my friend, $\mathrm{Mr}$. C. A. Delmar, who has been fortunate enough to shoot a Golden Oriole. He says : ' I heard of its arrival from my brother, who resides at Elmstone; he wrote to me on June 6, asking me to come over to shoot a Golden Oriole, which he had seen and heard in the very same spot where a male and a female Golden Oriole, with their nest and eggs, were taken last year about this time. I had the good luck to shoot this bird on the 6th, and on comparing it with the others we are of opinion it is a female; the colour of the plumage is not very bright, and resembles the female taken last year. I have stuffed it, and it is now in the possession of my brother, with the birds shot last year. WVe looked the place well over and found only this bird, and iny brother has been to the spot every day since, but has not seen or heard another. A very beautiful male Golden Oriole was shot at Lydd, in the latter part of May last, by a farmer who saw it settle on his window; a female was also seen, but she escaped. Before hearing of the Golden Oriole from my brother at Elmstone, I saw in the marshes on my way to Word a Golden Oriole fly from a thick bush to a bush a short distance off; at last it flew away in the direction of Word, and I was not able to find it again."-J. W. Hulke, Deal, June 17, 1850 (Zoologist, 1850, p. 2851).

There are specimens in the Canterbury Museum from Mr. IV. Oxenden Hammond's collection from Elmstone in Kent.

Golden Oriole Nesting near Deal.- "A few days since, when at Sandwich, a person there who partly gains his living by bird-stuffing, told me that ten years ago the Golden Oriole bred in Word IVood (a small wood on the border of the marshes, very boggy in winter, with very 
luxuriant carices and tall herbage); that he saw an old one, but would not shoot it, hoping to find the nest, for which he ineffectually searched. On making a second visit to the spot a few days after he was told by a countryman that he had found a nest with young ones, which he had given to his ferrets; and from the description of the nest he had no doubt it was that of the Golden Oriole.'-J. W. Hulke, Deal, January 8, 18.51 (Zoologist, 1851, p. 3034).

Occurrence of the Golden Oriole (Oriolus galbula) at Eltham.- "A beautiful example of the Golden Oriole was shot on the 14th of this month (June, 1853), at Eltham, in Kent, by Mr. Joiner, of Crown Manor Cottage, Eltham, and is now in my possession. Colour of bill dark red; head and back yellow; tail-coverts rich yellow; throat and breast yellowish-white; tail yellowish-black, tipped with rich yellow. Length, 10 inches."-James Bramley, June 19, 1853 (Zoologist, 1853, p. 4014).

A specimen in the Maidstone Museum was shot at Weavering Street near the above town, about 1866, and was presented by the owner, Mr. A. T. Killick, June 6, 1896.

Golden Oriole near Faversham._. A female specimen of the Golden Oriole was shot in an orchard near Faversham early in the autumn (1868). The man who shot it stated that it was in company with another bird of the same species." -John Hunter (Zoologist, 1869, p. 1:513).

Mr. Edwin Ward wrote to the Zoologist, 1869, as follows: "There was shot, on June 2, 1869, by Mr. Wiggins, leeper, Southfield Park, Tunbridge Wells, a fine female Golden Oriole (Oriolus galbula). On examination I found the bird must have had a nest of eggs or young ones at the time it was killed." 
Mr. Edward Newman, in his remarlis on the Golden Oriole in England in the Zoologist, 1870, states that Mr. C. Gordon, of Dover, received one killed on April 29, 1870 .

There are three specimens in the Exeter Museum, a male and two females, labelled Rent, the bequest of the Rer. Bower-Scott.

Mr. J. E. Harting gives the following interesting account of the nesting of the Golden Oriole in Kent in the Field of October 3, 1874 :-

"Although the discovery of a Golden Oriole's nest in England is not unprecedented, it is of sufficiently rare occurrence to attract the attention of naturalists, more especially when the finder (as in the case to which I am about to allude) has the humanity and good sense to permit the young to be reared, instead of shooting the parent birds the moment they are discovered, and thus effectually putting a stop to all attempts at nidification.

"It is a pleasure to be able to record the fact that during the past summer a pair of Golden Orioles took up their quarters in Dumpton Park, Isle of Thanet, where-the proprietor, Mr. Bankes Tomlin, having given strict injunctions that they should not be disturbed-they built a nest and successfully reared their young, ultimately leading them away in safety.

"They must have commenced building somewhat later than usual, for it was not until July 6 that I first heard of the nest, and the young were then just hatched. Mr. Bankes Tomlin having kindly invited me to come and see it, I lost no time in availing myself of the invitation, and a few days later, namely, on July 12, I found myself at Dumpton Park, standing under the very tree in which the nest was placed. The reader may smile at the idea 
of joumeying from London to Ramsgate merely to look at a nest; but if he be an ornithologist he will know that Golden Orioles' nests are not to be seen in this country every day, and that when found they are worth 'making a note of.' Often as I had seen the bird and its nest on the Continent, it had never been my good fortune until last July to meet with it in England. Indeed, the instances in which nests of the Oriole have been found here and recorded are so few that they may be easily enumerated.

"The nest which I am now enabled to record was placed in a fork of a very thin bough of an elm tree at a considerable height from the ground, and almost at the extremity of the branch, so that it was impossible to reach it except by cutting off the branch near the trunk. Happily, in this case, there was no need to reach it, and the finder was enabled to ascertain when the young were hatched by sending a man up the tree high enough to look into the nest withont disturbing it. A few days before his first ascent there had been a strong wind blowing for some time, and the slender branch was swayed to and fro to such an extent that, notwithstanding the depth of the saucer-like nest, one of the eggs was jerked out upon the grass below and broken, though not irreparably so. When I saw it it was in two pieces, but unmistakably the egg of an Oriole, in size equal to that of a blackbird, but shining white, with black or rather dark claret-coloured spots at the larger end. It has been carefully preserved by Mr. Tomlin.

"As long as his man remained in the tree the hen bird continued to fly round, uttering at intervals a loud flute-like note, and occasionally making a curious noise, such as a cat malies when angry. 
"It is, perhaps, scarcely necessary to remark that, as regards situation, form, and the materials of which it was composed, the nest did not differ from those which one is accustomed to see upon the Continent. Invariably placed in, and suspended under, the fork of a horizontal bough, the sides of the nest are firmly bound to each branch of the fork with blades of dry grass and fibrous roots. There is generally a good deal of sheep's wool in the nest itself, which, taken in connection with its peculiar shape, gives it a very singular and unique appearance.

"On July 12, as we approached the nest in question, the hen bird was sitting, but left as we advanced and perched in a neighbouring elm, whence at intervals she uttered the peculiar noise to which I have referred. Not wishing to keep her too long from her young we left the spot in about ten minutes, after carefully inspecting the nest with a binocular. Returning again in half an hour, and a third time two or three hours later, we saw the hen on each occasion quit the nest and take up her position as before at a little distance. Once only did I catch a glimpse of her more bright-coloured mate as he darted between two trees. He was very shy, and silent too, being seldom heard except very early in the morning, or at twilight. This, however, is the case with most song-birds after the young are hatched, for they are then so busy providing food for the little mouths that they have scarcely time to sit and sing. Mr. Tomlin, who had other and better opportunities for observing him, gave me to understand that he was not in the fully adult plumage, so that it seems the males of this species breed before they have assumed their beautiful black and yellow colours. 
"On July 22 the man again ascended the tree and peeped into the nest. The young had flown, but were subsequently discovered sitting about in the park with the old birds. As soon as the nest was no longer wanted, Mr. Tomlin had the branch which supported it cut off, and, writing to me on the subject the following day, he observed that 'upon examining the nest we found the corners tightly bound with long pieces of matting. One would almost imagine that a basket-maker had been at work.'

"Both the old and young birds continued to haunt the park until August 1, after which date they were no longer seen. The young were, however, well feathered by that time, and able to take care of themselves. Let us hope that they contrived to escape the eyes of prowling gunners beyond the park, and that they will return again next spring to gladden the eyes and ears of their kind protector.

"It is much to be wished that other proprietors would follow the good example thus set by Mr. Tomlin. Could they be induced to do so, they would become acquainted with many beautiful birds which visit us from the Continent every spring, and which would in most cases rear their young here if allowed to remain unmolested. Apart from the gratification to be derived from seeing these brightly coloured birds within view of the windows, and hearing their mellow, flute-like notes, they would be found to be most useful allies to the gardener in ridding the trees of caterpillars, which they devour greedily, and keeping many other noxious insects in check."

Mr. Bankes Tomlin, of Dumpton Park, Thanet, wrote to the Field, August 14, 1875: "Mr. Harting gave a long account of the nesting of a pair of Golden Orioles 
in my park during the previous summer. You will be interested to hear that this year a pair (whether the same or not I cannot say) have again built a nest in my grounds and raised their young. The latter left the nest on June 28, 1875. The old male bird was very bright in colour, being of a rich yellow with black wings." "On April 21 I saw in Westerham Park, Kent, a male specimen of Oriolus galbula feeding in company with two or three thrushes. I watched it for nearly half an hour, hoping to see a female Oriole, but failed to detect one. I have abstained from recording this rare visitant, trusting to give it a chance of life, until it had overcome the fatigue of migration.-J. T. Carrington (Zoologist, 1889, p. 234).

Mr. G. Dowker, in his Birds of East Iient (p. 42), says: "At this date (June, 1889) we have some Golden Orioles at Preston, near here" (Stourmouth).

"On May 15 a Golden Oriole (female) was shot in an orchard close to High Halden. A few weeks later (June 9) a male was observed near Sissinghurst (about eight miles from the former place). On the day after its arrival rain fell heavily, and the bird was lost sight of, taking refuge, no doubt, in the thick fir portions of the Hemsted Woods. Prior to the above records another male bird appeared during May, 1893, in the same wood. The 'Loriot' call, whence this bird derives its name, attracted the keeper's attention, and thinking his boy, engaged in arranging Pheasant-coops in a wood below his cottage, was whistling for help, he started out in the direction of the sound. This eventually led to the discovery of the bird, and also to its destruction."-Boyd Alexander (Zoologist, 1896, p. 346). 


\section{Family LANIIDÆ.}

\section{Genus LANIUS, Linnæus.}

\section{GREAT GREY SHRIKE.}
Lanius excubitor, Linnæus. S.N., i., p. 135 (1766).

Great Shrike, Boys, 1792 ; Great Butcher Bird.

The Great Grey Shrike is an occasional autumn and winter visitor to the county of Kent, and generally solitary. 'The number of instances recorded and the dates of the occurrences are mostly in October and November.

The Rev. J. Pemberton Bartlett, in his Omithology of Kent, 1844, calls this bird the "Ash-coloured Shrike," and says that "this bird has been shot in the neighbourhood of Dover." In the same year Mr. J. B. Spencer noted the capture of the Great Grey Shrike at Blackheath on or about October 12, 1844, and he says: "A birdcatcher whom I occasionally employ has just brought me a specimen of the Great Butcher-bird, which he caught in the act of pouncing on one of his lure birds : it was taken alive, and I regret he killed it, as I should like to have studied its habits. It agrees most exactly with Bewick's woodcut and description. Mr. J. H. Gurney, jun., states, in the Zoologist, 1869: "I received a Great Grey Shrike, in the flesh, from Dover, on November 14, 1869. It had only one white spot on the wing, and the breast is marked with numerous greyish semilunar lines; hence $I$ conclude it is a female. Mr. Stevenson remarks (Birds of Norfolk, p. 62) that he has examined old females which showed no trace of these semilunar markings, and were exactly like males, with, I presume, two white spots on the wing." 
The following observations of this species are given by $\mathrm{Mr} . \mathrm{H}$. J. Harding, of Deal, in the Zoologist, 1871: "It is not often one can get near enough to the Great Grey Shrike (Lanius excubitor) to observe the strange way in which it strikes its prey. On a fine day in the early part of November, having three Linnets and a Redpoll in cages, I put them out in the garden on the ground. About ten in the morning I came out of the cottage to see if the birds were all right, when I observed a strange-looking bird cutting some queer gambols among my cages. At first sight I took it for a Jay, but soon discovered it was a specimen of the Great Grey Shrike. I got within about eight yards of him, when he flew over the hedge with something in his beak. I waited a little while to see if he would return, which he did in about ten minutes; he immediately made up to a Linnet's cage and began springing up about a yard high and dropping again, with his claws distended, on the cage. This performance he repeated several times. I thought he meant no good to my Linnet, so drove him away, but he soon renewed his attack on another cage. I was now within six yards of him, so I tried to take him with a net; but he was not to be had, and flew over the hedge. But what did I behold! My poor Redpoll hanging in the cage without his head. It was this that he flew over the hedge with when I first observed him. In about two hours after this he again returned and played the same antics as before. I again tried to take him, but he was too wide awake, and flew up, to return no more."

In the Kentish Collection in the Maidstone Museum there is a pair which were obtained at Boughton Monchelsea, presented by Mr. R. J. Balston ; a male obtained 
at Boughton Monchelsea by Mr. F. Smith, in February, 1881 ; and a female taken at Ulcombe, November, 1891, by $\mathrm{Mr}$. G. Bensted. In a note on this species by $\mathrm{Mr}$. H. Lamb, a male was shot near Maidstone on January 19, 1887, and two others were seen that same winter. In the Zoologist, 1890, Mr. WV. Oxenden Hammond says : "While shooting in the woods here (Wingham) at the end of November (1889), a Great Shrike came out close to one of the guns. My friend, who knows the bird well, said, the day being a bright one, it looked like a gleam of silver as it went past him. It went on to an adjoining cover, but we did not meet with it again." According to Mr. WV. Prentis, in his Birds of Rainham, this species has been obtained in that district several times.

Mr. S. A. Davies, in his ornithological notes from the mouth of the Stour, near Sandwich, says: "On October 2,1895 , in the course of the morning we went inland over the marshes, which are here studded with tall thorn-bushes. Seeing a black and white bird fly from the ground into a thorn-bush, I followed it up, and found that it was a Great Grey Shrike. True to its name, "excubitor," it was too wary to let me get within shot, and would fly from one bush to another, pausing at times, and hovering in mid-air, like a Kestrel. After I had followed it from tree to tree for a quarter of an hour it flew across the Stour, and as there was no means of crossing the river I gave up the pursuit." 


\section{PALLAS'S GREAT GREY SHRIKE.}

Lanius major, Pallas. Zoogr. Rosso-As., i., p. 401 (1811).

The only reference to hand of the occurrence of this species in Kent is that of a specimen in the British Museum, viz., an adult female skin obtained at Plumstead, in Kent, October 5, 1878, and presented by Mr. H. Whitely.

\section{LESSER GREY SHRIKE.}

\section{Lanius minor, Gmelin. S.N., i., p. 308 (1788).}

The only observations on this species in Kent were made by Mr. F. W. Frohawk, at Bromley, which appeared in the Field, May 29, 1897, and the Zoologist, 1897, p. 427, and are as follows:-

Lesser Grey Shrike (Lanius minor) in Kent.-"I am pleased to be able to record another occurrence of this very rare visitor to this country, which I observed on May 15 (1897) last, on the range of hills in Mid-Kent, while in company with my friend Mr. John Wood. As we passed under an ash-tree I heard a strange note overhead, and looking up, I saw a bird fly out with a rather jerky flight, and uttering short notes, resembling, as well as I can remember, the sounds chur-tic, chur-tic, tic. These notes were new to me, and from the appearance of the bird, as seen against the background of brilliant blue sky, I was quite at a loss to make out the species; but it soon dipped down, and its striking colours became visible against the hill under which we were standing. The bird then alighted on the ground for a few seconds, 
when I brought my friend's field-glasses to bear on it, which at once revealed the pattern and richness of its plumage. I then instantly knew what a rarity I was watching; the silvery-grey, deep black-and-white of the upper parts, and the delicate pink breast and flanks, looked particularly rich in the sunlight, and in strong contrast with the turf on which it stood. It then flew up and perched on a small hawthorn, from that again to the ground, and then on to a furze-bush. After two or three such movements it disappeared over the brow of the hill. After waiting a short time, I saw it again further along the hillside, chasing a small bird, I think a Linnet, but the distance was too great to make sure of the species, though the colouring of the Shrike was plainly visible. From the intensity of the black markings it was clearly a male. I think it very probable that it had taken up its abode on the hill for nesting purposes, for which the character of the place was admirably adapted; and if opportunities had been afforded, I intended paying another visit to the ground later on with the hopes of seeing more of the bird and perhaps its nest. - F. IV. Frohawk, Bromley, Kent (Zoologist, 1897, p. 427).

\section{RED-BACKED SHRIKE.}

Lanius collurio, Linnæus. S.N., i., p., 136 (1766).

Butcher Bird. Red-backed Shrike, Boys, 1792.

Many secluded parts of Kent are favourite resorts of the Red-backed Shrike, which is plentifully distributed throughout the county during the summer. It prefer's the wild bramble-covered hillsides and over-grown hedge- 
rows, where it may be seen sitting at the end of a branch, especially a dead one, from which it can dart off after its prey.

The Rev. J. Pemberton Bartlett, in his Ornithology of Kent, 1844, says: "A year or two since I observed a male Shrike of this species flying with a bird in its claws, after the manner of an owl. Being curious to know what bird it was, I threw a stone at it; whether I hit it or not I could not tell, but the effect was that it dropped its prey, which I found to be a Blue-headed Titmouse. These birds are very generally distributed throughout the county. They arrive in this neighbourhood about the first or second week in May, and are seldom seen after the end of August."

This species was seen at Boxley on May 24, 1872, and also at Springfield, Maidstone, on November 25, 1886.

Dr. A. G. Butler, during his bird's-nesting in Kent in 1875, found the nests of this bird at "Barming, near Maidstone, on June 2 and 7, 1875, two nests, built in bushes, were varieties (?), the eggs resembling those of the Grey Shrike. Barming, June 2: Nests larger than the preceding, heavier in construction, and built in the forks of elder and hawthorn trees."

A pair with three young, the nest, and a female from Boughton, Monchelsea, are in the Maidstone Museum, presented by Mr. R. J. Balston. This species is included by Captain J. D. Cameron in the Birds of Bethersden, and the Rev. C. H. Fielding, in his Birds of the Malling Valley, gives the localities of Cobham, Shorne, Cuxton, Mereworth and Great Comp.

In his notes on birds in Kient Captain Boyd Alexander says: " Families of Red-backed Shrikes are abroad. Stout hedgerows, whose out-growing branches serve as perches, 
or the sunny portions of a wooden fence, are at this time favourite resorts. They flit in close company from bough to bough in front of an intruder, the male parent bird uttering frequently his brisk chuck. Mimicry is also resorted to, the movements of the Spotted Flycatcher being then very closely imitated, and except for his red-brown mantle and inordinately long tail he might at first sight pass easily as that bird. When on a fence this Shrike will often turn backwards round its perch, and cling to the bottom of it after the manner of a Titmouse. Several nests of this species may frequently be found in close proximity to one another. A 'tiller' (a local name given to a young oak tree) or some other favourable position, not far from the nest, is always chosen as a look-out post, and this is resorted to for some time before building is commenced. Incubation is performed by the female, who leaves her nest and flies to the 'tiller,' and is there fed by the male."

This bird was seen at Capel, Orlestone, on June 9, 1902, and at Falconhurst, on May 25, 1906, a pair were observed. Dr. A. G. Butler states that he took fresh eggs as late as June 8 in Kent. Mr. R. T. Filmer says: "It is a strong lover of the bushy slopes of the railway about Orlestone. I have seen at least five or six nests every year."

\section{WOODCHAT.}

Lanius pomeranus, Sparrman. Mus. Carls. fasc., i., No. 1 (1786).

The Woodchat is certainly a very rare summer visitor to the county of Kent, and the number of authentic instances of its occurrence are few. The earliest is 
noted in Mr. G. R. Gray's Catalogue of British Birds in the British Muscum (p. 83, 1863) "a, Kent; male."

Professor Newton, in Yarrell's British Birls (vol. i., p. 216), says: "In the British Museum there is a specimen of the Woodchat, a young male, which formerly belonged to Leach's collection, and is labelled as having been killed in Kent"; and Mr. O. V. Aplin, in his Status of the Woodchat (Zoologist, 1892, p. 349), adds: "It is probably the bird which was killed in the neighbourhood of Canterbury, and that it is not enumerated, however, among the specimens now in the Museum in vol. viii. of the Catalngue of Birds." No doubt the above is the same specimen mentioned by Morris, from near Canterbury. There is also a male labelled Kent in the Exeter Museum, the bequest of the Rev. Bower-Scott.

In 1857 Captain $H$. W. Hadfield published in the Zoologist an account of his finding a Woodchat near Tonbridge, which is here subjoined:-

"May 14, 1857: Went out in quest of birds, and had not proceeded above a quarter of a mile from the town when I observed a strange one fly across the road; there was a pecularity in its appearance, as well as flight, which attracted my attention, and I felt sure it was a species I had never before seen; consequently hastened to load my gun, and while doing so it passed so close that I could not only distinguish the reddish-brown patch on the head and neck, but a fly that it had captured and still held between its beak. Having seen it alight on an oak tree some fifty yards off, I followed it up and shot at it, when it fell among some nettles, but being merely winged it crept into a hedge, where it was subsequently seen by some boys who had joined me in the search, which was continued for an hour or two. 
As I distinctly saw the rufous of the hind neck there can be no doubt of its being the Wood Shrike."

Professor Newton also states that "the bird has been obtained near Brighton, and a second time in Kent," without further data.

In 1868, Mr. A. Clarke-Kennedy wrote the following notes on the Woodchat to the Zoologist, September 11, 1869 , p. 1863 :-

"For several days during the month of July, 1868, a Woodchat Shrike had been known to frequent gardens in the neighbourhood of Faversham and Murston, but for a time all endeavours to shoot the bird were unavailing, as it was extremely wild. Towards the end of the month, however, it was seen upon a cherry tree in an orchard at Murston, by Mr. N. Barlow, who killed it, and took it to a local taxidermist, who informed him that it was a common bird and of no value; but as soon as the possessor of the rarity had departed the unscrupulous dealer sold it to a gentleman who well knew its worth, and for a large sum. My friend, who is not an ornithologist, afterwards found that he had been cheated out of a fine male specimen of one of the rarest birds that visit this country."

Mr. O. V. Aplin states that Mr. W. Oxenden Hammond, of St. Alban's Court, Wingham, writes: "As to the Woodchat, about three years ago (1899), I heard from a bird-catcher at Dover that he had just caught one. I went at once to see it, and learn about it. The bird was in beautiful plumage, all the feathers, tail and wings perfectly clean. The owner told me that his men had taken it in the warren near Folkestone. That when they saw the bird it entered a dense clump of bramble, going to the bottom, and that they enclosed it in the 


\section{$-$}




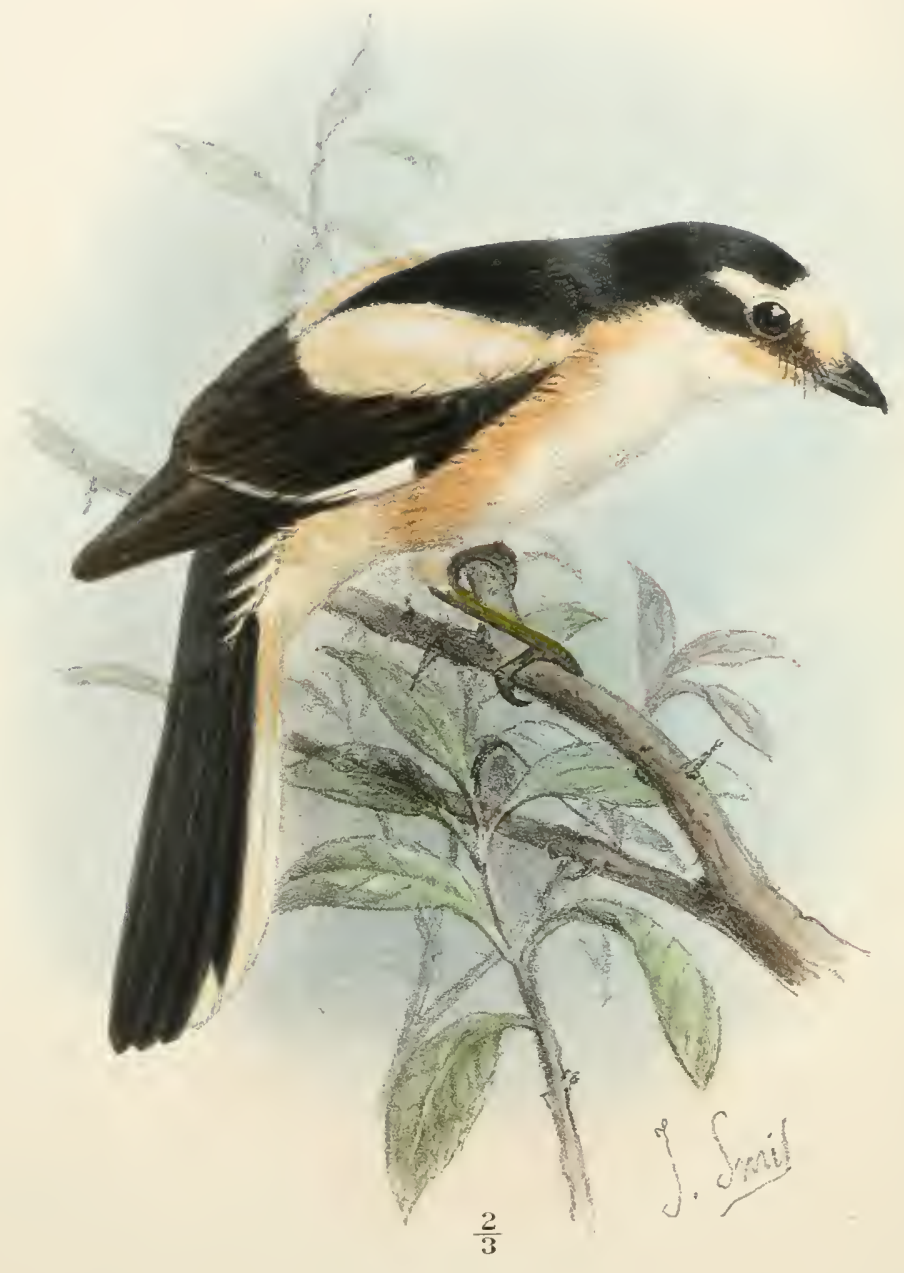

7 Sml del et lith

Bale \& Damielsson, $L^{\text {td }}$ imp.

MASKED SHRIKE

LANIUS NUBICUS, Licht. 
bramble, and so caught it. I look on it with a certain amount of suspicion." This bird is in Mr. Hammond's collection, now in the Canterbury Mruseum, labelled from Dover Cliffs.

The Rev. C. H. Fielding, in Malling and its Valley, 1893, states that it was also seen in 1890 at Sittingbourne in Kent, without giving any data.

\section{MASKED SHRIKE.}

Lanius mubicus, Licht. Verz. Doubl., p. 47 (1823).

The Masked Shrike was only added to the British birds in 1905, and the record of the occurrence was made by Mr. M. J. Nicoll, who exhibited a specimen at a meeting of the British Ornithological Club on October 18, 1905. This specimen was an adult male, which had been shot at Woodchurch, Kent, on July 11, 1905, and examined by Mr. Nicoll while in the flesh (Bulletin of the B.O.C., vol. xvi., p. 22).

\section{Family AMPELID压.}

\section{Genus AMPELIS, Linnæus.}

\section{WAXWING.}

Ampelis garrulus, Linnæus. S.N., p. 297 (1766).

The most beautiful bird that visits this county is the Waxwing; one cannot but admire the blending of its soft, silky plumage, its form, and graceful movements. Unfortunately, it is only a winter visitor, when its secluded habits of keeping to the thicker forests of fir 
trees and larger woods prevent the ordinary observer from seeing the beanties of the bird.

In Yarrell's British Birds, 1871-74, Professor Newton remarks "that it is impossible to fix the precise time of this bird's risitation, as Latham, for instance, states that one was killed at Eltham in the winter of 1781, without indicating whether it was in the winter of 1780 81, or that of 1781-82" ; no doubt it was obtained in 1781, whether at the commencement of the year or at the end is of minor importance.

An adult skin of the Waxwing from Kent is in the British Museum; it was presented by Colonel Montagu.

The Rev. J. Pemberton Bartlett, in his Ornithology of Kent (Zoologist, 1814), states that "several specimens of this beautiful bird have been taken in Kent. In the autumn of 1840 I was attracted by the strange note of a bird in an Acacia in the garden, which proved to be a Waxwing. I speedily got my gun and shot at it, and it fell in a fir plantation near, but from the high grass and not being certain of the exact spot in which it fell I was unable to find it, although I made a long and keen search."

Mr. Walter W. Reeves wrote saying that "a Waxwing was shot at Brenchley, near Tunbridge Wells, on January 6, 1850."

On January 16, 1860, Dr. F. Plomley wrote stating that "several WVaxwings had been shot in different parts of the county."

On January 22, 1850, Mr. Edward Newman in the Zoologist says: "I have notices of this bird having been killed last week in many localities round London, viz., Eltham and Rainham, \&c."

"In the last week of January, 18.50, a Waxwing was 
shot near here (Deal). In the first and second weeks of January, 18t8, eight were shot."-J. W. Hulke, Deal.

Mr. A. Clarke-Kennedy states: "I have this day (December 3, 1867) received a letter from my friend, Mr. H. Whitely, of IVoolwich, who tells me that he has had brought to him, during last week, no less than eight good specimens of the IVaxwing. This species is now, I believe, a very rare and only occasional visitor to the British Isles. Some of these were shot in the Plum. stead Marshes, near Woolwich, and two were procured in the Maryon Road at Charlton, which is about four miles from Plumstead. They were all, I believe, excellent specimens. I do not know on what days they were shot, whether on fine ones or the contrary; but I presume that it was partly owing to the weather that such a number (in comparison) should be taken about the same time."

Mr. WV. Prentis, in the Birds of Rainham, says: "The Waxwing is extremely rare in this district, only two, to my knowledge, have been obtained; one was shot from a pair in our woods in 1867, another obtained in an orchard the same year. A small flight was seen in an orchard at Milton."

The Waxwing was seen by the Rev. C. H. Fielding at Higham, and others round the neighbourhood of Rochester, in the winters of 1879-80 and 1880-81. An occasional and very pretty winter visitor.

There is a specimen of the Waxwing in the Canterbury Musemm, from Nonington, the bequest of Mr. W. Oxenden Hammond, and one killed in Kent, presented by Mr. G. Simmons, in the Maidstone Museum, and a female was procured at Smarden, January 4, 1893 (Land and Water).

Mr. Ogilvie-Grant reports that two examples of the 
Waxwing (Ampelis garrulus) had been caught at Ramsgate at the beginning of December, 1903, by a Mr. Young. One of the birds having died, was forwarded, on December 8, to the Natural History Museum (Bulletin, vol. xiv., p. 31, 1904).

\section{Family MUSCICAPIDE.}

\section{Genus MUSCICAPA, Linnæus.}

\section{SPOTTED FLYCATCHER.}

Muscicapa grisola, Linnæus. S.N., i., p. 328 (1766). Post Bird.

The Spotted Flycatcher is not an abundant species during the summer in Kent, being a more or less solitary bird, and only to be seen in pairs during the breeding season. When once they talie up a position on the outskirts of, or in, a wood, they may always be found darting off after insects from a dead branch and returning to a similar one close at hand.

In his notes on the birds of Rainham in 1868, Mr. F. D. Power says: "Flycatchers remained about the orchards in considerable numbers until September 26, when all disappeared." Captain Boyd Alexander, in 1896, writes: "Around our gardens a few families of Spotted Flycatchers are still to be met with. These are the late broods. Although the majority of the young can look after themselves, yet in each family there are one or two wearing the spotted livery of first youth, that have still to depend upon a mother's care. The task of feeding these devolves solely upon the female parent. 
$\mathrm{Her}$ mate has tired of her love-play, for as soon as the nestlings are abroad he leaves her, and becomes once more a bachelor. Then catching prey for this backward brood she faces the prevalent breeze, and this enables her to detect more readily the insects' drifting course."

Dr. A. G. Butler gives an account of the variation of nests taken in Kent in 1883 ; he says: "I took a cupshaped nest, apparently referable to the Spotted Flycatcher, in a high hawthorn hedge bounding a private garden. This nest is formed of slender roots, moss, and fine bleached grass-stems, compacted with spiders' web, and is lined internally-but most thiclily towards the bottom-with reddish hair, amongst which a few coarse black horse-hairs are twisted; the cavity is unusually deep. The nest contains only two eggs, rather large for the species, of a pale green tint, sparsely spotted with russet, excepting at the large end, where they become denser and form a mottled patch. A nest in my collection of the shape of a slipper was found in a hole in a wall in June, 1885, by my friend $\mathrm{Mr}$. IV. Drake, of Kemsley, in Kent. The nest contained three eggs, which completely filled the cavity."

Captain J. D. Cameron includes this species in the birds of Bethersden, and it was obtained on May 28, 1902, near Orlestone. Mr. R. T. Filmer says: "A pair of these birds built their nest and reared their young under the door of the Ham Street signal-box in 1904. It was not until June 28, 1906, that the first Flycatcher's nest was found. It was placed on an old stump sticking out of the side of a large elm tree, by the Royal Military Canal below Ruckinge. The nest was so beautifully formed and decorated with lichen, that at first sight it appeared to be part of the stump." 


\section{PIED FLYCATCHER.}

Muscicapa atricapilla, Linnæus. S.N., i., p. 326 (1766).

The following occurrences of this species in Kent are few, and no doubt the bird is overlooked. Deal: "On September 17, 1850," says MIr. C. A. Delmar, "I observed a curious little bird engaged in catching flies near some bushes. On shooting it, it proved to be a Pied Flycatcher."

On September 17, 1869, at Cobham, Lord Clifton states: "I was attracted by a small bird, looking like a miniature hen Chaffinch, flitting about the branches of an oak: after some observation I perceived that it was a Pied Flycatcher in the brown and white plumage."

Mr. W. Prentis, in his Birds of Rainham, says one of a pair was shot in a wood-lane, by a small pond, May 1 , 1871. It is in the collection of Dr. F. Plomley, at Dover. Mr. G. Dowker records it from the Stourmouth district. A specimen is in $\mathrm{Mr}$. W. Oxenden Hammond's collection in the Canterbury Museum, which was obtained at Elmstone. Captain J. D. Cameron says it has been shot at Bethersden in Kent, and the Rev. C. H. Fielding records a specimen from Ramsgate. Mr. J. F. Green one at the "Cedars," Lee, Kent. 


\title{
Family HIRUNDINIDÆ.
}

\section{Genus HIRUNDO, Linnæus.}

\author{
SWALLOTV. \\ Hirundo rustica, Linnæus. S.N., i., p. 343 \\ (1766).
}

House-Swallow, Chimney-Swallow. Swallow, Boys, 1792.

Few birds that are summer visitors to this county, besides the Nightingale, have drawn upon themselves more attention than the well-known and beautiful Swallow. No spring or summer wonld be complete without them. This homely bird, with its delightful skimming flight around the home of man, is a pleasure to all, and the vast benefit derived by its presence to agriculturists, by the consumption of insects, is very great.

Among the following details of the arrivals and departures of the Swallow, which are given in a more or less chronological order, and with the time of nesting, will be found, perhaps, some useful material for future observation. The Rev. J. Pemberton Bartlett wrote to the Zoologist, 1844, as follows: "From the remarks of two of your correspondents, the Rev. J. C. Atkinson (Zoologist, 354) and Mr. Hepburn (Zoologist, 147), on the places chosen for nidification by the Hirundo rustica, it appears that in the localities they mention these 'welcome guests of settled spring' but rarely build in chimneys. Now in Kent it is quite the reverse -building in chimneys with them here is the rule, and outhouses and barns the exception. Where we have 
one building in a barn or outhouse, we certainly have an average of four or five which build in chimneys. One year five chimneys in a house were occupied by Swallows, three of which had been regularly tenanted by them for many years. There is hardly a cottage which has not its pair of Swallows, which annually return to their favourite chimney.

"The following curious instance of the perseverance of these little birds was noticed. Three years since a pair of Swallows, after reconnoitring the place for some days previously, very assiduously commenced building their nest against the interior wall of the porch of Kingston church. Then the nest was about half finished it was discovered by the person who swept the church, and the consequences was it was cleared away. But the industrious little architects, undaunted by this calamity, again set to work, and the following week the nest was rebuilt. This also was destroyed, but no sooner was it removed than a third was commenced; but this, alas, soon shared the fate of the others-being removed by the churchwarden. After meeting with such continued and decided opposition, the birds at length left their favourite spot, and repaired, no doubt, to some less public haunt. But the most remarkable thing is, that they have every year since gone back to the porch and commenced their nest! And although they have not been permitted to hatch their young, yet their love for the spot seems unshaken. The cause of the hostility to this luckless. pair of Swallows, on the part of the sexton, was that they liept the porch in a constant litter with the straws. and mud which fell from the nest; and on that of the churchwarden, that their twittering and chattering disturbed the congregation. Swallows generally arrive here. 
about April 10, and the majority leave us about the first week in October; occasional stragglers may be seen throughout the month."

In the spring of 18t4, Mr. M. Hutchinson, in his remarks on the summer arrivals at Shooter's Hill, Kent, says: "The early part of April was bleak and cheerless; but on the evening of the 15 th the wind changed, and we had a soft, steady breeze from the south-west. I felt confident the morrow would bring with it some fresh arrivals. I was not disappointed. As I crossed WVolwich Common under the opening eyelids of the morn of the 16th, I met a pair of Swallows steering due west, doubtless making the best of their way for the more genial west of England. Their first appearance was noted the same day at Eltham. In the spring of 1845 , on the afternoon of Sunday, April 6, I was surprised at observing two Swallows comfortably hawking over the pond to the east of Eltham Park. I did not notice another Swallow till the 12th, and they did not arrive in force before April 21; our own Swallows came on May 2."

Morris, in his British Birds, says: "Being at Milstead, near Sittingbourne, Kent, I noticed in the course of a walk by Torry Hill, a white bird on the wing, which proved to be a young Swallow, when it settled on a rail, where I shot at it sitting. White ones have also occurred at Frinstead."

Mr. Arthur Hussey, writing to the Zoologist, 1855, says: "I have received information that, towards the end of October, 1854, a white Swallow was killed in the neighbourhood of Sandwich, having been observed and pursued by several persons. The head, neck, and upper parts of the back were a delicate silvery light 
brown, shading off on the under parts, tail and wings to a not very pure white; and the bird is stated to have looked brilliant in the sunshine."

On October 23, 1856, Captain H. TV. Hadfield, of Tonbridge, records the "last Swallow observed by me in this neighbourhood; it was flying about the church steeple, where I had previously noticed a few for some days."

Mr. J. Jenner WVerr, writing in October, 1857, says: "I have seen at Pembury the nest of the Swallow under the eaves of a bouse. Unlike that of the Martin (Hirundo urbica), the nest was not attached or closed at the top, but supported underneath by the bend of a zinc waterspout."

On April 23, 1859, Mr. M. Hutchinson "saw a pair of Swallows hawking over the round pond at Blackheath," and on September 21, 1859, he found hundreds of Swallows resting on Blackheath. "On April 22, 1861, a Swallow was flying high over Shooter's Hill; April 26, one Swallow at Blackheath; April 28, one Swallow at Chislehurst and one by the round pond in Blackheath Park; April 29, three were hawking on the heath; April 30, two at Eltham Moat and one on the pond at Filbrooke Farm; May 9, one Swallow at Blackheath. The early Swallows could not stay at home for want of food. I generally first meet with them on the old ponds. The season has been too cold to develop sufficient insect-life. At 5.15 p.m., on Friday, April 8, 1864, I saw one Swallow flying over St. Germain's Place, Blackheath; its flight was due east, weak and weary. On Thursday afternoon, April 21, I saw a pair of Swallows and four Martins flying about the round pond in Blackheath Park. In the afternoon of Tuesday, April 26, I saw a House-Martin 
flying over the same pond; it signalised its arrival by pitching right and left into the Sand-Martins located here since April 21. On Thursday, April 20, 1865, at 5.50 p.m., I saw one Swallow fly over St. Germain's Place. On April 18, 1866, at 6 p.m., I saw an old Swallow fly north across Blackheath. April 24, half-adozen Swallows hawking over Upper Long Pond in Blackheath Park. April 26, in the evening, saw one Swallow take a turn or two under the lee of the gravelpits by Greenwich Park wall, and then fly off north."

The first Swallow seen by Mr. W. H. Power at Rainbam was on April 18, 1865. The first Swallow seen at Maidstone in 1867 was on April 15, and again on April 23, 1868. It had been flying about in a snowstorm.

Mr. F. D. Power, in his notes on the birds at Rainham, during September and October, 1868, states that "an immense southward migration took place early in October, most marked on the 6th, 7th, 8th and 9th. Hundreds were passing for two or three hours each morning in an almost continuous stream, and flew very low, only just skimming over the Saltings."

Dr. A. G. Butler found the Swallow breeding at Tong Mill, on June 5 and 11, in the rafters of a boat-house.

Mr. H. Lamb saw it on April 22, 1876, near Maidstone, for the first time that year, and the last on November 8, 1875. Some white Swallows were shot near Maidstone a few years previously.

Mr. J. E. Harting records one that was seen at Walmer on December 11, 1880, during a light north-west wind.

In the Zoologist, 1883, Dr. A. G. Butler, in his notes on the variation of nests of birds found in Kent, says : "As is well known, the Swallow alone has spotted eggs, 
and these I have on several occasions noticed to be more heavily marked when the light had direct access to the top of the nest than when it was built under the rafters of darkened barns or deep down in chimneys."

In Dr. R. B. Sharpe's Monograph of Swallows (vol. i., p. 235), Mr. E. Bartlett writes: "Museum, Maidstone, September 15, 1885. Lately our benefactors, Messrs T. and J. Hollingworth, ordered the huge Elizabethan chimneys over the Hall and Great Hall of this Institution to be restored, and knowing that the Swallows had bred in them for years, I was anxious to see the position of the nests. In the first chimney I found a nest of four eggs on June 15, 1885, at the depth of 7 feet from the top of the stack. In the second stack of chimneys, with several shafts, and some of them extremely narrow, I found a nest of three eggs on August 20, 1885, 6 feet 6 inches from the top of the stack; they had been sat on for about five days, therefore the young would be hatched about the 28th of that month, and if we allow six days for the young to become fully fledged and able to fly from the nest, it would bring the date up to September 3. In another shaft of the same stack was a nest with four unfledged young, which was 8 feet 6 inches from the top of the stack; and in such an extremely narrow shaft it appeared almost impossible for a Swallow to descend to so great a depth. I had often watched them, and noticed the old birds hovering over the top of the stack before descending, and from what I have now seen I am convinced that the Swallow descends to the nest with upraised wings, dropping straight down to any depth necessary. I have often caught the young birds which had fallen into the rooms from these great chimneys, having no doubt attempted the ascent from the nest 
before they were able or strong enough. In the third great stack I found two nests-one was 11 feet 2 inches from the top, and the lower portion of it was many years old, showing that several nests had been added to it, and this year's new work was easily recognisable; the young had been reared in it."

Mr. W. Prentis, in his Birds of Rainham, 1894, says: "We do not seem to have so many Swallows now as we used to have, the successive cold springs and wet summers have told very much against them. According to my observations their numbers have been reduced by more than half. There was only one pair on my chimney-top last year, instead of three; this may not be the case everywhere. No doubt with finer summers our insectloving birds will increase. The spring of the year 1869 was a very severe one for the Swallow. On May 28 I observed one lying dead beside my farm buildings, and another flying more like a bat than a bird over my garden hedge; others were seen by my brother, Mr. Edward Prentis, at his farm in the parish of Chalk, near Gravesend, with their heads under their wings for warmth, upon his horses' backs in the stables."

In his Notes on Birds in Kent (Zoologist, 1896), Captain Boyd Alexander remarlss that "the congregating movements prior to migration are not the least interesting feature in bird-life. Swallows and Martins make an alliance, and they may be seen all day long winging their mazy courses to and fro over the cut cornfields, and so deep at times do the Swallows pitch their flight, that they well-nigh brush the shaggy corn-stalks with their breasts."

Among the birds seen on the beach at Dungeness, Mr. T. Hepburn found, on May 10 to 14, 1900, a good 
many of these birds building in the recesses of the sham forts on the artillery range, and on July 20 he found a nest under the eaves of a shed on the marshland with five fresh eggs in it.

On April 15, 1902, a Swallow was observed in the Orlestone district.

Ruckinge, October 10, 1905: The Swallow is still here in numbers. On the 16th they were found in large numbers lying on the red tiles of a country house, in a lane between this place and Snave, sunning themselves in the early morning. They were seen continually up to the 20th; the majority had now left the village. On the $23 \mathrm{rd}$ several were seen on the road by Bilsington, and on the high warm slopes on the south-east side of Lympne Church, overlooking Romney Marsh. On the 23rd a great many still remained. On the 25th a young Swallow was seen on the hills above Ruckinge at 10.30 a.m., and an adult bird was hawking by the bridge of the Royal Military Canal at 12.15 p.m. On the 26th a pair still remained in the village. On the 27th no Swallows; on the 28th, one had returned, and the last.

In the spring of 1906, Mr. D. F. Warde noted the Swallow on April 13, at or near Canterbury, as being the first seen. Mr. J. H. Allchin, of Maidstone, saw one at Thurnham, Kent, on the same day, and another solitary bird at Dymchurch on April 21. On April 26 three were noticed about the farms near Orlestone, and on April 30 they had taken up their old homes at Bilsington.

Early in June, 1906, at Ruckinge, the Swallows had completed four wests in a cart-shea, and on the 24th the young ones were fully fledged, and left the nests shortly afterwards. One pair brought off a second brood, which left the nest about August 27 or 28. This last nest was 
built on to the slanting rafters of the roof, close up in the angle near the tiles, and it was tapered downwards to a point, without any support beyond being attached to the narrow rafters above. There were six nests in the angles of the roof of a woodshed close by, all within a few feet of each other.

\section{Genus CHELIDON, F. Boie.}

MARTIN.

Chetidon urbica (Linnæus). S.N., i., p. 344 (1766). Martin, Boys, 1792 ; House-Martin.

The Martin, like the Swallow, is plentiful throughout the county during the summer, and few towns, villages, isolated farmhouses, or cottages, are without their Martins, the only reason for the absence of the Martin from a house being that the eaves are not suited for the construction of the nest. It appears evident that the nest of the Martin must be so constructed that the eaves should form the cover for the top of the nest; the sides of the nest are closed up, and attached to the over-hanging roof, thus leaving only a small aperture in the front top edge of the nest for the birds to pass in and out. In one instance the birds commenced building a nest on the front of a cottage and then found that the underpart of the eaves was open to the inside of the roof; they abandoned the position when half through their work.

In another instance the Martins selected the front of a house, where the eaves had been painted a stone colour; this paint extended on to the bricks below the over- 
hanging roof, leaving a smooth surface. The birds completed the nest so rapidly that no time was allowed for the mud to dry, the consequence was that the weight of the nest brought it down; nothing daunted, the birds set to work and built another, with the same result. They left the place, but towards the end of July they returned and built half the nest again, and made a roosting shelf of it for the rest of the season.

The subjoined material has been collected of the arrivals, nesting and departure of the Martin in Kient. Mr. M. Hutchinson says: "On April 29, 1845, I observed two House-Martins masticating mud for their Irish cabin; they appeared to have been here (Shooter's Hill) a day or two. Our Martins arrived on May 16. In the spring of 1846, while walking to the stable at half-past 7 a.m., and looking at the clouds, I suddenly exclaimed, "What, a Swallow? No! it flies like, but cannot be, a Martin." A quick turn, however, exposed its white rump, and sure enough there was a HouseMartin on April 1. On my arrival home, after my morning's ride on Sunday the 5th, I caught the sound of a Martin's twitter, and on looking up, there was our House Martin making a figure of 8 round the two blocks of houses, singing and chattering in very gladness of heart."

Mr. J. Hulke wrote, December 8, 1849: "I saw three House-Martins at Kingsdown, under the cliff. I watched them for some time, in order to be sure of what they were. Had they not, perhaps, been hibernating in some cleft, which they had left on account of the unusually warm weather?"

Mr. C. Collingwood records the arrival of the Martin at Kidbrook on April 17, 1854, and Mr. MI. Hutchinson 
observed it on May 1, 1859, at Blackheath, and again he met a pair in Lee Lane, and saw a pair building at Eltham on May 12, 1861; another pair were hawhing over the houses in the Dover Road. In Mr. W. H. Power's Birds Observed at Rainham, 1865, the Martin is recorded as "first seen on April 28, 1865. These birds have been accustomed to breed under the eaves of the houses as long as I can remember, and probably for many years before that date. They have lately evinced a great reluctance to abandon their ancient nesting-places, and for the last two years, as fast as they completed their nest, the gardener, who entertains a strong aversion for them, on the ground that they make a litter while feeding their young upon the path and grass in front of the house, has proceeded to knock down the nests with a broom or some such instrument. The Martins, however, with a pertinacity worthy of a better reward, have constantly rebuilt. I am happy to say that I have this autumn obtained a promise that they shall not be interfered with in future."

On April 24, 1866, Mr. M. Hutchinson saw two HouseMartins hawling over the upper long pond in Blackheath Park.

Lord Clifton records, in 1867, a pure white Martin at Cobham, in Kent.

In Mr. J. Gould's Birds of Great Britain, 1873, appears the following passage: "Captain King says in his Narrative of a Journey to the Shores of the Aretic Regions in 1833-35: "While residing in Kent about ten years ago, having selected a detached nest, I fastened a small piece of silk round one of the legs of its inmate then sitting upon eggs. The following season the bird returned, and, with the garter still affixed, was secured in the samt nest, 
a convincing proof of the instinctive knowledge attributed to it.'

In 1875, Mr. H. Lamb saw a Martin on December 8, flying round All Saints' Church at Maidstone. Colonel H. W. Fielden, late of Dover, wrote: "On November 15, 1857, whilst driving past Kearsney Abbey, I and my companion counted five Martins flying about the first reservoir between that place and Dover. The striking feature was that the banks of the dam were powdered white with snow, and thin pancake ice had formed close to the edges. Waterhens were swimming, and Dabchiclis diving, amongst the thin ice, and above, but skimming close to the water, was this party of Martins. It was an exceptionally cold and wintry day for this time of year, and I quote an extract from the Standard of November 16: 'A Dover correspondent telegraphed last night, "Wintry weather has set in on the coast unusually early, a somewhat heavy snowstorm having been experienced in this district to-day. Snow commenced falling last night and fell for several hours, continuing at intervals throughout the day. It is several inches deep on the hills, and in some places there is reported to be as much as a foot. The wind is bitterly cold, and the sliy is overcast and threatening. The wind blew very heavily last night from the north.", ,"

In 1898, Mr. F. D. Power, in the Zoologist, wrote under the heading of When does the House Martin Arrive? the dates he collected at that time. The following are the dates of arrivals in Kent: 1862, April 28 (one), Rainham, lient; 1865, April 28 (one), Rainham, Iient (visiting old nest) ; 1866, April 16 (two), Rainham, Kent (visiting old nests) ; 1890, May 7 (five), Northfleet, Kent; 1892, May 8 (three), Greenhithe, Kent. 1905, 
April 12, Kent (B.O.C. Report). 1906, May 2, Ruckinge, first seen in numbers, about their old nests. In the autumn (October 10, 1905), in the surrounding districts and Ruckinge, the Martins were still about the Royal Military Canal and villages; on the 17 th the greater part of them had left, but on October 23, a great many were found among the Swallows on the high slopes on the south-east side of Lympne Church overlooking Romney Marsh. On November 10, at 9.30 a.m., a pair of Martins were flying about the garden at Ruckinge; it was a very mild morning. In the Bulletin of the B.O.C. (vol. xii., p. 26, 1903), "Mr. Digby Pigott reported, on the authority of Mr. R. Norton, of Downs House, Yalding, that in November there were young Martins in a nest in Kent. Mr. Norton had watched the mother feeding them for some minutes."

Genus CoTILE, F. Boie.

$$
\text { SAND-IIAR'TIN. }
$$

Cotile riparia (Linnæus.) S.N., i., p. 344 (1766). Sand-Martin, Boys, 1792.

The Sand-Martin on its arrival in Kent is very abundant, and for a few days only skims the surface of the ponds and rivers for food, generally in company with the Swallow, and then they take to the inland sand-pits for the breeding season. If the sand-pits are large, the birds are very numerous, but in many instances only a pair or two occupy a high bank where there is not sufficient room for more.

Mr. C. Collingwood records the arrival of the Sand- 
Martin at Beckenham on April 15, 1854, but it was not observed until May 10, 1906, while hawling over a large pond at Bilsington in Kent, in company with some Swallows.

This species, according to Mr. W. H. Power, is " an uncommon species in the Rainham district, and he only saw a few in the autumn of 1865." Near Maidstone and Aylesford there are a great many sand-pits which are taken up annually by the Sand-Martins. Mr. R. T. Filmer says it is commonly seen hawking along the railway in the Orlestone district. The bird becomes local during the breeding season on account of the absence of sand-pits and suitable high banks of soft earth.

Attempt to Keep the Sand-Martin in Confinement."Thile in Fient last July, a man brought me five young Sand-Martins which he had just taken from their nest. The burrow from which they had been taken having been destroyed, and the birds themselves being too young to fly, I determined to do my best to keep them alive. The idea of giving them their natural food being out of the question, I mixed up for them a paste consisting of four parts of fig-dust and pounded dog-biscuit, two parts pea-meal and yolk of eggs, and one part ant's eggs; but it was quite a week before they would take this food from a feeding-stick, and the task of opening theit mouths for every morsel was one which I should not care to repeat. After about ten days all five fed themselves greedily from a small glass pot of food, and I then turned then into a large flight-cage, hoping that they would take sufficient exercise to keep them in health. In this, however, I was disappointed, for, although at first they took short flights and roosted high up on the perches, or 
rockwork, in the cage, they gradually spent more and more time in cramming their crops, and one by one they dropped off, until, at the end of the twenty-second day, the last of the five died. I may add that, although when first taken these young Sand-Martins were beautifully clean, they so messed their faces with the soft food it was necessary to give them, that before they died all their beauty had departed."-A. G. Butler (Zoologist, 1887, p. 348).

\section{Family CERTHIID瓜.}

\section{Genus CERTHIA, Linnæus.}

TREE-CREEPER.
Certhia familiaris, Linnæus. S.N., i., p. 184 (1788).

Creeper, Boys, Sandwich, 1792.

This curious little bird is far from plentiful in Kent, and its preference for old orchards and rough old trees is well known. This may be for a partial disguise and protection, the colour and markings of the plumage assimilating with those of the bark on which they cling. It is a very pretty sight to watch a pair of Tree-Creepers on a bright, sunny morning in early spring climbing a lichen-covered apple or other tree, when they display the beautiful markings of the wings and tail by spreading them out and lying flat on the trunk of the tree in the sun. In this position, unless they move, they are lost 
to sight, on account of the resemblance to the surrounding bark of the tree.

It is included in the fauna of Higham and the Malling Valley by the Rev. C. H. Fielding, and Bethersden by Captain J. D. Cameron. It is rare in the Orlestone district according to Mr. R. T. Filmer. One was seen in Burnt Oak Wood on March 6, 1902, and it has been observed to catch flies like a Flycatcher. Mr. W. Prentis, in his Birds of Rainham, says: "Though pretty generally distributed the Creeper is not an every-day bird with us; we now and then catch a glimpse of one in our orchard trees; they do upon occasions nest in the orchards."

In May, 1905, at Orlestone, a Tree-Creeper built a nest between two upright posts which formed one side of a doorway to a thatched and faggot-sided poultry rearing shed. There happened to be a notch in one of the posts, which formed a ledge between the two, and only left space enough for this small bird to pass in and out. Not far off in the same shed a Wren built its nest in the faggots which formed the walls of it.

On May 31, 1906, not far from the above shed, a TreeCreeper's nest was found, built between two upright black feather-edged boards, which stood with a number of others against a fence under some trees. The leaves of the overhanging trees had fallen between these two boards and made a foundation for the nest, leaving scarcely space enough for the bird to pass in or out. 


\section{Family FRINGILLIDÆ. \\ Genus CARDUELIS, Brisson. \\ GOLDFINCH.}

Carduelis carduetis (Linnæus). S.N., i., p. 318

Goldfinch, Boys, 1792.

This beautiful little bird was becoming very scarce owing to the large numbers taken every year by the bird-catchers and others, who shot them down for ornaments in glass cases, but since the passing of the Birds Protection Act they are certainly on the increase all over the county, and it is very promising to see so many pairs in all directions. Of course, in the autumn and spring the usual increase in flocks is caused by the movement southward from the northern counties; by this migration southwards, and the return, a great many more remain in Kent every year than formerly since they have not been canght or disturbed.

The Rev. J. Pemberton Bartlett, writing in 1844, states that the Goldfinch was then common. It was after his time that the destruction began. Lord Clifton, during December, 1869, and January, 1870, saw at different times several Goldfinches in some alder-trees at Cobham, showing that at that time it was looked upon as a rarity. There are specimens in the Maidstone Museum obtained at Hollingbourne in December, 1880, and also the nest by Mr. G. Coveney, and at Boxley on January 16, 1883, by Mr. WV. Hickmott. Eggs were taken at Boughton on May 29, 1885. It is also included among the birds of Bethersden by Captain J. D. Cameron. 
Mr. G. Dowker, in 1889, says: "The Goldfinch is less destructive to farm produce, and most useful in destroying thistle seeds: but though met with in tolerably large flocks, is not so abundant as I remember it. This, I believe, is owing to the bird-catchers." Dr. A. G. Butler remarks : "In the north of Kent, where the nest might be obtained fairly commonly about a quarter of a century ago, it is now hardly ever met with."

On May 22, 1902, a pair of Goldfinches were seen at Bilsington, and during the autumn of 1905 several pairs were met with in the Orlestone district.

Mr. D. A. Bannerman, of Westerham, Kent, writing to the Zoologist, 1904, says: "I have noticed with great pleasure the marked increase of Goldfinches this autumn, and at the present time (October 15, 1904) in this neighbourhood quite large flocks of them, twenty birds or more, may be seen mingling with the countless numbers of Brown Linnets, Chaffinches, and Greenfinches, which fly in clouds from the hedgerows and stubble as one passes. This increase is, I conclude, due to the Wild Birds Protection Acts, which, I believe, prohibit the killing or taking of the Goldfinch throughout the year."

\section{Genus CHRYSOMITRIS, Boie.}

\section{SISKIN.}

\section{Chrysomitris spinus (Limnæus). S.N., i., p. 322 (1766).}

Siskin, Boys, 1792 ; Aberdevine.

In the autumn large numbers of Siskins are to be seen throughout the county of Kent, either in pairs or mixed with flocks of our winter residents, such as Chaffinches, 
Sparrows and Linnets, during severe weather. But when the fine open winters are warm the Siskins usually remain in pairs, and by this it appears that they are not so sociable, and prefer to have a solitary or married life.

With regard to the species having bred in Kent, no satisfactory evidence or data have been recorded.

In the last edition of Yarrell's British Birds (1871-74), Professor Newton says that "Latham, in a note to the edition of Pennant's British Zoology published in 1812, states that he received from Lewin a male and female shot in summer in the latter's garden in Kent." The Rev. J. Pemberton Bartlett, in 1844, calls this bird "the Siskin or Aberdevine, and that it arrived at the end of autumn in considerable flocks."

There are several specimens of males and females of this species, which were obtained on the following dates: January, 1877, December 9, 12, 13, 1887, and January 3, 1888, in the collection of the Hon. WValter Rothschild, which were all obtained at Tovil, near Maidstone, in Kent.

There are three males and two females in the Maidstone Museum from Tovil, procured on December 12, 1890, and presented by R. J. Balston, Esq. Dr. A. G. Butler, writing abont 1903, says: "I am tolerably sure that the Siskin has bred at Keston in Kent." Mr. R. T. Filmer noticed in the autumn of 1904 a pair in the company of Redpolls in alder-beds, in the railway cutting at Orlestone; and during the autumn of 1905 several pairs were met with on the road to Ashford, and also at Ruclinge and Bilsington. 


\section{Genus SERINUS, Tioch.} SERIN.

Serimus serinus (Linnæus). S.N., i., p. 320 (1766).

The Serin is an occasional visitor to this country, and the only instance recorded of its occurrence in Fent is that given by Mr. D. Seth Smith (Zoologist, 1904, p. 457): "On November 16, 1904, I received a live Serin (Serinus hortulanus), which had been caught a few days before by a bird-catcher at Dover, and I have since heard that a second example was taken at the same place on the day I received mine. Both these birds were associated with Linnets."

\section{Genus LIGURINUS, Kioch.}

\section{GREENFINCH.}

Ligurimus chloris (Linnæus). S.N., i., p. 304 (1766).

Greenfinch, Boys, 179?.

Among the summer and winter residents in Kent, the Greenfinch may be considered one of the most numerous. It is to be seen and heard all the year round, and collects in large flocks in winter, mixed at times with the Chaffinches, Sparrows and others, and breeds freely in all the overgrown thorns, brambles and furze bushes on the waste land, especially very old hedgerows. On May 25 several nests were found with three eggrs in each, these were built with wool and green moss. Lord Clifton, in writing to the Zoologist, 1867, sars: "Mr. 
Clogg mentions a Yellow-Hammer's nest found on August 26. I found a Greenfinch's nest, with young ones, in a blackthorn, about that date, certainly in the last week in Angust."

Dr. A. G. Butler, in his observations on the variation of common bird's nests in Kent, says: "Excepting in strength and size, I have observed little variation in the nests of the Greenfinch, the principal difference consisting, so far as I have seen, in the presence or absence of wool, the substitution of fine fibre or hair in the lining, and the partial substitution of bleached grasses for twigs and coarse roots in the external structure. The eggs, however, vary much more, a clutch of five in one of my nests being zoned with dull blood-red or dark russet mottling, upon which are a few short darker red-brown linear markings."

The eggs of the Greenfinch are most variable both in colouring and in shape, some being almost perfectly round, while others are oblong and appear deformed.

On Seplember 16, 1887, Dr. A. G. Butler " took a nest of three young Greenfinches, apparently about five days old, out of a plum tree in an orchard near Sittingbourne, in Kent." Mr. T. Hepburn found the Greenfinch nesting in numbers on May 10 and 14, 1900, in the holly and furze bushes on the beach at Dungeness.

Throughout the district of Orlestone, Mr. R. T. Filmer says the Greenfinch is common, and it is included among the birds of Bethersden by Captain J. D. Cameron.

The Song of the Greenfinch.- "I have stated, in The Evolution of Bird Song (p. 126), that the 'tewy' alarm (a slurred whistle) is never uttered in the song of the Greenfinch. I regret to say that this statement was inserted in the correction of the proof, and was made 
from memory, without reference to my notes. I find that the cry in question, the true danger-cry of the Greenfinch, is sometimes included in the song. Also, it is not always slurred upwards, but sometimes remains at the same pitch, when it much resembles a note given by the common canary in the presence of a stranger. The Greenfinch employs the note in the presence of a Hawk, Cuckoo, Cat, Dog, or IVeasel. One day last spring I heard a kind of rhythmical repetition of this note, it being alternately slurred upwards and downwards by some Greenfinch, so that the song seemed to run: Tewy tewoo, tewy tewoo, tewy tewoo, and so on. After listening to this for a minute I thought I had discovered a new strain in the Greenfinch, namely, one composed entirely of the danger cry. On investigation I found a female Greenfinch, evidently disturbed, on the lower branch of an oak in the thicket, she was watching something below her; and soon a Cuckoo flew up, and, seeing me, went off. The notes of the Greenfinch immediately ceased, and were not renewed. On other occasions the single cry has been given when a Cuckoo was near."-C. A. Witchell, Eltham, Kent (Zoologist, 1897, p. 335$)$.

\section{Genus COCCOTHRAUSTES, Brisson.} HAWFINCH.

Coccothraustes coccotirraustes (Linnæus). S.N., i., p. 299 (1766).

Grossbeak, or Hawfinch, Boys, 1792.

In olden times the Hawfinch was supposed to be only an uncertain visitor to the various parts of England, and was overlooked by early writers on account of its shyness, 
and habit of slipping out of sight, but of late years it has been found to remain throughout the year, especially in all the old orchards and secluded woods in Kent, where it breeds annually in large numbers. In 1844 an example of the little that was known of this bird's habits was written by the Rev. J. Pemberton Bartlett, in his Ornithology of Kient, who states that the Hawfinch "visits us in winter, but not in great numbers." Morris, in his History of British Birds, 1852, says: "It has been known to breed regularly near 'l'enterden, Bexley, Dartford, Maidstone and Penshurst, in Kent." In 1858, Mr. 'T'. W. Greene, of Tonbridge, gave the following particulars of the Hawfinch building there: "A pair of Hawfinches have built their nest this year in an orchard in the vicinity of Toubridge; but, unfortunately, the nest has become a prey to a prying school-boy, who took the first egg and substituted in its place a small Blackbird's egg. The next morning another egg was laid, but the Blackbird's was gone; the birds were then again robbed of their eggs, and have in consequence deserted. Their nest, however, has not been built entirely in vain, for a pair of House-Sparrows, seeing it deserted, are now constructing their clumsy domicile on the top of it."

In 1867, Lord Clifton, of Cobham Hall, adds the following respecting the Hawfinch in Kent: "Hawfinches have been unusually numerous here this spring. I saw three on April 13, the first I had ever seen, and became acquainted with their note, tzit, or tzit-it, the knowledge of which was of great use to me afterwards in detecting them among the tall leafy hornbeams. On April 25 I found a nest begun in a whitethorn, built of sticks, with lichen conspicuously interspersed in it. This I found, from that oft-quoted and very accurate description 
in Latham's Synopsis, to be that of a Hawfinch; and I soon found another nest in a tall whitethorn, by means of the old birds, who kept up a continual agitation around me. I now actively pursued the search, and found between that time and May 8 eight other nests with eggs, and five which I considered new nests, they being either difficult of access or unfinished when I went away. Of this large number all were built in thorn trees save the following-three in elder bushes, about 5 or 6 feet from the ground, one in the hanging branches of a slender holly tree (this one quite close to the house), one on the horizontal bough of a hornbeam, one in a yew tree. By following up their note I found a flock of about twelve among some tall hornbeams. Some of these would probably have built nests subsequently to my departure. 'To find ten undoubted Hawfinch's nests is, I believe, a rare occurrence for a young ornithologist, especially considering that I had never seen a Hawfinch, for certain, previous to the four weeks in which I found the nests. Mr. Doubleday remarks on the extreme wildness of the Hawfinch in Epping Forest. As far as I have observed, it is not always very wild. Last winter I observed one hopping about on the grass within ten paces of the house (Cobham). When seen so near, the white bill of the winter plumage had a very odd appearance, giving one the idea of a bird with a piece of bread in its mouth. I imagine that some Hawfinches leave us in the winter and return to breed."

In his notes on the birds at Rainham, Mr. F. D. Power says: "Octolver 9, 1868, saw one Hawfinch. Not an uncommon species in the summer, but always rare in the winter months."

Mr. A. Skinner, of Faversham, states: "In June, 1869, 
I observed several Hawfinches feeding on some cherry trees in this neighbourhood; they were very shy, and conld scarcely be approached within gun-shot. I succeeded in bringing down one, a fine male. A man living near the spot shot five at various times afterwards, two of which were young ones."

In 1873, Mr. J. Gould, in his Birds of Great Britain, says: "In Kent the Hawfinch is very abundant. I may mention many other localities where it may be found, such as the pleasure grounds of TV. WVells, Esq., at Redleaf, in Kent."

In the last edition of Yarrell's British Birds Professor Newton says: "The Hawfinch is most abundant in Kent. This is shown by the fact that in the present year (1876) Lord Clifton, as he has informed me, knew of more than fifty nests at Cobham." The Hawfinch is included among the Birds of Bethersden by Captain J. D. Cameron, and according to Mr. R. T. Filmer, a few birds usually visit the cherry orchards at Ham Street every winter.

In May, 1876, Mr. H. Kennard, who took great interest in British birds, brought to the Maidstone Museum the first nest in that institution ; it contained four eggs, and was found at WVest Farleigh. Mr. Kennard cut it out of an apple tree which was in full bloom. The nest being covered by grey lichens and placed among the apple-blossom, formed one of the most beautiful nests imaginable.

Mr. H. Lamb found several young Hawfinches flying about in the cemetery at Maidstone in June, 1887. One of the old birds was with them. A pair with nest and eggs, and two young birds in the mottled plumage, were obtained at Boughton in 1887, and presented to the Maidstone Museum by R. J. Balston, Esq. 'There is 
also a pair from the same locality procured on May 9, 1887, and presented by $\mathrm{Mr}$. E. Bartlett to the same Museum, and a female from Leeds in Kent, obtained on March 4, 1890, and given by Mr. H. Elgar.

In 1887, Mr. E. Bartlett was collecting particulars respecting the Hawfinch in Kent, and his specimens are now in the collection of the Honorable Walter Rothschild, and the data of these are as follows :-

Female, December 16, 1887, Tovil, Maidstone; two males, May 11, 1887, Boughton, Kent; male, May 20, 1887, Boughton, Kent; one male and two females, May 25, 1887, Boughton, Kent; male and female, young, July 13, 1888, Boughton ; wale, young, July 23, 1889, Boughton ; female, January 6, 1888, Boughton; male, February 3, 1888, Boughton ; male and female, February 4, 1888, Boughton ; male, February 21, 1888, Boughton ; (?), March 26, 1888, Boughton; two males and female, April 3, 1888, Boughton.

Most of the crops of the birds taken during the winter contained the lieruels of damson and cherry stones, but in one of those talien in May the crop contained fifty green caterpillers.

Food of the Hawfinch.- "A favourite summer food of the Hawfinch is green peas; the quantity they will consume is rather astonishing. In the autumn I found in their stomachs the kernels of a small stone-fruit, which, as the birds had been frequenting bullace trees, and the odour of prussic acid was very strong, I have no doubt they obtained from that fruit. A very favourite food seems to be the fruit of the yew, and I have also found what I have not the slightest doubt were the kernels of the whitethorn. Both the kermels of the bullace and whitethorn were divested of the hard shells." - T. Southwell (Zoologist, 1888, p. 117). 
Food of the Hawfinch.- "As regards Hawfinches feeding on the kernels of cherry and plum stones (referred to on p. 117), I may note that some years ago I had a pair of Hawfinches sent up from Norwich in the flesh. Upon skinning them the odour of prussic acid was very marked, and they were found to be crammed with the undigested kernels of plum and damson stones. This was late in autumn, and it should be borne in mind that the stones had doubtless been exposed for weeks to the action of the weather, and were, in consequence, more readily opened than they would have been when fresh from the fruit."-A. B. Farn (Zoologist, 1888, p. 187).

A great many of the specimens above noted from Boughton and procured during the winter were found to have the base of the mandibles coated with mud, caused by their habit of digging out the damson stones from the ground beneath the trees.

\section{Genus PASSER, Brisson.}

\section{HOUSE-SPARROW.}

Passer domesticus (Linnæus). S.N., i., p. 323 (1766).

\section{Sparrow, Boys, 1792.}

The Sparrow is the most familiar and home-loving bird found in Kent. There is not a house, cottage, shed, or haystack which is not made use of in one way or another by the Sparrow. The mischief they do, and the food they eat, are well known to all farmers, at the same time, during the breeding season, they consume a vast 
number of destructive insects, which may to a certain extent compensate for the grain they have eaten.

Note on a Singular Noise made by a Sparrou.- "I have more than once heard the singular noise made by the House-Sparrow, noticed by the Rer. A. Hussey in the December number of the Zoologist, 353. The first time I heard it was about two year's ago. My attention was attracted by a strange note which proceeded from a bird in an apple-tree, which I cautiously approached, fully expecting to discover some rara avis. In this, however, I was disappointed, for after carefully scrutinising every branch, I could discover nothing but some Sparrows; and feeling pretty sure that no bird had flown from the tree since I heard the sound, and being unable to discover the cause from which they were produced, not suspecting at all that so common a bird as a Sparrow was in reality the author of this unlinown noise, [ began to think it was vox et praterea nihil. But. hearing it repeated, it struck me it must have proceeded from a Sparrow. After watching them for some little time, I presently heard the noise again, and this time I was fortunate enough to detect an old cock Sparrow in the act. He appeared at the moment to be in a state of considerable excitement; his head was stretched out almost on a line with his back, his wings and tail were fluttering, and he was evidently under the influence of some passerine emotion. My impression at the time was that the sounds (which appeared to me to be a sort of buzzing croak) proceeded from the throat of the bird, but I might be mistaken. I have heard the same sounds once or twice since, but have not again been able to see the bird in the act of emitting them, although I knew that Sparrows were the authors of them, as they were 
the only birds I could see in the trees from whence the sounds proceeded. From the attitude of the bird in question, and his whole gesture, I am inclined to think the sounds must have been used as a sort of love-note. But then the question arises, if it be so, why do we not hear it more frequently? And this, I confess, I am unable to answer."-J. Pemberton Bartlett, Kingston Rectory, December 4, 1843 (Zoologist, 1844, p. 453).

House-Sparrow.- " Probably it may have been observed, but I am not aware that I have seen it remarked on, the somewhat peculiar habit the House-Sparrow has, not only of resorting to and occupying its old nest, but of repairing and relining it for the winter, when the leafless trees no longer afford it a secure or suug place of roosting; I say somewhat peculiar, because I am aware that it is recorded of the Wren, that it retires at night and in severe weather to its old nest. I find it inserted in my note-book: "Ventnor, October 13, 1854. Saw a House-Sparrow carrying feathers into its nest under the eaves.' Again, 'Tunbridge, November 1, 18.56: Observed this morning a House-Sparrow carrying feathers into the ivy on the ruined castle in this town. In the afternoon saw another Sparrow, with its bill crammed full of dry grass, fly on to the cottage and disappear among the creepers." "- H. W. Hadfield, Tunbridge, November, 1856 (Zoologist, 1857, p. 5363).

Notes on the House-Sparrow (Fringilla domestica)."March 31, 1857: Rather more than a week since a pair of Honse-Sparrows commenced building in one of the small elm trees in front of the house; the site selected for the nest is a forked branch near the top, and the work seemed to be progressing till a sudden change in the weather not only put a stop to it, but the drenching 
rain, which during the last few days succeeded the snow, has almost washed away the few straws that had escaped the violence of the equinoctial gales; however, I observed, both yesterday and to-day, the unfortunate couple endeavoming by renewed exertions to repair damages, but as the weather still looks threatening, I think the new foundation not unlikely to follow the old. The position chosen for the construction of the nest is not only a most unsafe but an unlikely one, for the tree, as I have already observed, is by no means a large one, and might be climbed with ease, as the branch on which it is placed, although not large, is strong enough to bear the weight of a good-sized boy. It is wonderful to think what these birds can manage to malie a nest stick on, for at present it seems to consist merely of a few loose straws balanced on the forked branch so insecurely that one would imagine the merest puff of wind would send it flying before it. Why they should have selected a tree, and such a tree, I am at a loss to conjecture, as there are houses and outbuildings in all directions. They are not Tree-Spartows, however, although they might possibly be taken for such, as Montagu tells us that 'every House-Sparrow that has built its nest in a tree (by no means an uncommon occurrence) has at once been pronounced to be the Tree-Sparrow, and consequently that species has been supposed to be more plentiful, and more generally diffused throughout England, than we have any reason to believe is the fact.' . . . April 4: The late tempestuous weather has completely swept away the new nest, not one straw remaining, but the patient and indefatigable birds are still there, seemingly unwilling to quit the scene of their past labours, nor should I be surprised to find them shortly renewing their en- 
deavours; but how the female can, under the circumstances, manage to retain her egors till the nest may be ready to receive them is to me a mystery, unless she is endowed with the faculty, generally ascribed to the cuckoo, of bearing them about until a fit opportunity offers for depositiug them."-H. IV. Hadfield, April 14, 1857 (Zoologist, 1857, p. 5683).

Curious Site for a Sparrow's Nest.— "A remarkable case has just been noted. Professor Flower informs me that during a recent visit to Woolwich Arsenal, his attention was directed to a hen Sparrow sitting upon her nest containing five eggs in one of the axle-tree boxes of a 9-pounder bronze gun which is fired twice daily, at $1 \mathrm{p.m}$. and at $9.30 \mathrm{p.m}$. One would have supposed that at the first discharge of the gun the bird would have deserted the nest for ever, and that the consequent recoil and vibration would have disturbed the eggs so materially as to render them unproductive. It is satisfactory, however, to learn from Colonel Noble, R.A., that on May 16 five young Sparrows were hatched, and will probably be reared in due course."-J. E. Harting (Zoologist, 1885, p. 233).

Sparrow and the Crops.- "The House-Sparrow is a curious fellow, full of originality, as bold a bird for his size as is to be met with anywhere. His usual habitat is, as his name implies, in the neighbourhood of houses, chiefly towns or farms. In the towns there are always scraps to be thrown away, in the country the farmyards afford sustenance to the Sparrow; often in the former case, however, to the discomfiture of numerous halfstarved cats that abound in urban districts. It seems odd, too, that although there are laws and what not for the protection of most of our birds and beasts, yet very 
little is thought about the thousands of cats that must die every year, in London alone, of starvation. TVell our present thoughts are not now with the cats, but that most republican of birds, the sparrow. 'The Sparrow is a native of our isle, and he seems somehow to inherit the independent spirit which, at one time at any rate, was the boast of Englishmen as peculiar to the British race. He is gregarious by habit, building his nest in colonies, his favourite place being either the eaves of buildings or thatch of barns; if numerous, however, they will build in every green tree and shrub, such as the spruce fir or Portugal laurel. The nest, if built in the open, is circular-shaped, with an entrance at the side, whilst it is often more or less rudimentary when built under the sheltering roof. The first sound that greets the dweller either in town or country in the early morning, and one of the last as evening draws on, is the endless chatter of the Sparrow, for he-unlike most of our sombre-coloured birds-possesses no pleasing song with which to beguile the hen during the days of incubation. What all their conversation can be about would tax the most imaginative of mortals to determine, for the ordinary listener the distinguishing feature of their parliamentary wrangle seems to be repetition. They remind me very much of a number of almshonse gossips, whose sole aim appears to be to hear their own voices, to attain which it is necessary for all to speak at once. The Sparrow, however, is not always chattering, for he is a good forager; a veritable gourmand is he, few things come amiss to him, from the corn in fields to the cherries on the wall; with his powerful beak he shells the peas with wonderful celerity, and when detected will fly to the nearest wall and chirrup a bold defiance, as if he 
delighted in a spice of danger. Watch hin as he approaches the hens just fed with scraps from the table; in vain the cock-proud possessor of numerous wiveslets drive at him. No good, for he returns again and again, until at last he seizes in his beak the object of his desire, perhaps a piece of turnip half as big as himself, quickly to be dropped, however, as soon as some more palatable morsel is discovered. We have two or three cats here that feed regularly with the fowls; numerous sparrows, of course, are there to pick and steal, as is their wont. It is a curious fact that the cats malie no attempt to interfere with the Sparrows while feeding, the birds often feeding within springing distance. When Sparrows are numerous and food scarce, their pugnacious nature asserts itself; if, however, two hen Sparrows should disagree, the general result is interference by some old male bird who has probably won his spurs in many a hard-fought tussle, in right of which he lays claim to decide upon the merits of the case; but if the cocks delight to fight and scratch, the hens will look on with indifference. I have seen Sparrows attack and drive away starlings, even from the places where the latter had selected to nest. Around this house and buildings Swallows can get no place for their nests, owing to the fact that as soon as a nest is completed the Sparrows, in the calmest way possible, take possession. The Sparrow being a bird of social habits will, if encouraged, become tame, although like most bipeds of bullying propensities, they are maturaily suspicious, and will not as a rule, unless pressed by hunger, venture within the window; whereas there are many other kinds that will become very friendly by encouragement. I remember this last winter-by no means a severe one- 
a case of a Robin that used to sit on a stag's head in the dining-room here and sing whilst breakfast was going on, becoming so friendly at last that one morning he pounced from his 'coigne of rantage' and seized a pat of butter from my plate, which, however, soon slipped off his beak, much to his astonishment. Well, I must now draw my remarks on this best known of English birds to a conclusion. I much fear, however, that a hard time is coming for the country Sparrow, for he has increased so of late years, and the damage done by him to the cornfields is so great that the farmers, for the sake of their crops, will have to take steps to keep them within reasonable limits."-Herbert Gow Stewart, Hale Park, Rolvenden, Ashford (Zoologist, 1885, p. 307).

Writing in 1888, Mr. E. Bartlett says: "The back of this Institution (Maidstone Musemm) is beautifully covered with iry, which the Sparrow has taken possession of for year's, builds its nest and rears its young in perfect safety; but by permitting this to go on, I have lost (without thinking about it) a beantiful pink Maytree; they have by degrees eaten off all the small buds during the winter, thus preventing the tree from throwing out a single leaf, and since the dead tree has been removed they have taken to two others close by, which will, I fear, share the same fate as the first, for they make them a perfect feeding ground during the winter. 'They will even go so far as to have a tremendous family quarrel and flog their lady friends under one's nose, be it summer or in the depth of winter. I have witnessed this quarrel when the snow was 3 inches deep, and they (four in number) appeared more like young rats fighting for the last crust than birds, the snow flying in all directions. 
Roosting Habits of the House-Sparrow.- "Between Eltham and Sidcup, Kent, are some birch-thickets in which Pheasants are preserved. House-Sparrows come from all directions to sleep in these places. They begin to arrive at about 2.30 , and, until after four o'clock, they are continually coming in small parties of rarely more than thirty birds, flying high and fast, and seemingly from some distance. On December 29, 1895, I watched from 3.30 till 3.50-twenty minutes-and counted 453 Sparrows, besides a few Greenfinches, descending into a small area some 30 yards square, in one thicket. On another day, while walking 300 yards, I saw 153 Sparrows descend at the same place. They roost in small groups of from thirty to sixty birds, in the upper branches of the birches, many of them being in full view from the road, and all of them directly exposed to any rain that may fall during the night. In winter Sparrows ordinarily sleep either in their nesting-places in walls, on ricks, ivied trees, hedges, sc. I do not know of any British bird smaller than a Starling which ever selects so exposed a dormitory as that above mentioned. In the same district, also, Sparrows sometimes build in elms and other large trees, many of their nests being placed far out on the branches, domed and strong enough to withstand the winter; but they are not occupied at that season."-Charles A. Witchell, Sidcup, Kent (Zoologist, 1896, p. 77).

\section{TREE-SPARROW.}

Passer montanus (Linnæus). S.N., i., p. 324 (1766).

In Kent the Tree-Sparrow appears to keep more to the north-eastern portion of the county, and even there it is 
not very numerous, but that it breeds there is evident from the following records.

In 1844, the Rev. J. Pemberton Bartlett says: "TrecSparrows are tolerably abundant in winter, mixing with the House-Sparrows and Finches. I have met with two or three instances of their breeding in the holes of trees."

The Tree-Sparrow is included in the Birds Observed at Rainham, by Mr. W. H. Power, who writes: "Early on the morning of September 28, 1865, my brother and I for the first time noticed this bird near Rainham. We were returning from the marshes, when we heard the notes of the bird as it flew over in the mist, and recognised it at once. Although we tried hard, it was some days before any were obtained; indeed, for a day or two we lost sight of them, and began to be afraid they had departed altogether. I have usually found them associated in flocks with the common House-Sparrow, and although there is little difficulty in distinguishing the note of the Tree-Sparrow from that of the more common species, it is not so easy to tell one bird from another as they fly by in a flock, consequently the chances are considerably in favour of one's lilling a House-Sparrow, as I found more than once to my cost.

"In 1868, the Tree-Sparrow appeared on September 26 at Rainham. Large flocks were passing over in a north-westerly direction during the first part of October. Numbers always remain in the district during the winter."

Lord Clifton states that a large flock of Tree-Sparrows frequented a small wood at Cobham in the winter of 1868-9. Mr. H. K. Swann met with this locally breeding species somewhat commonly in three different places, namely, the seashore at a spot near Ramsgate, where it 
breeds indiscriminately in boles of trees, or crevices and holes in the sandstone cliffs, \&c.

There is a pair in the Maidstone Museum which were obtained at Hollingbourne in January, 1893, by Colonel Franklyn.

Dr. A. G. Butler gives the following details of nests of the Tree-Sparrow in Kent:-

Unusual Nesting-site for the Tree-Sparrow.- "On May 21, 1887, whilst examining some exposed moleburrows (many of which had been deepened or adopted by Sand-Martins) in a brick-earth cutting at Kemsing, near Sheppey, I observed proofs that one of the larger holes had been taken possession of by some birds; in fact, at my approach a Tree-Sparrow flew out almost in my face; on digging away the surface of the earth I exposed a nest lined with white feathers, and containing six perfectly typical eggs. It is well known that TreeSparrows in this country usually select pollard willows as nesting sites, the nest being frequently placed in a hole between the young branches of the partly decayed trunk; I have also found the nest in a hole in a large dead branch which had been cut off near the trunk.

"The whole of the nests which I have taken in Kent were found in holes in trees within a stone's throw of at least one house, and sometimes at a distance of only a few yards. In Kent I took one nest from a hole in the front of an old oak tree facing the road. The darker and more ruddy eggs are not characteristic of the species, but most of those which I obtained from Kentish nests were of the lighter varieties, though the eggs in a clutch sometimes exhibit considerable modification in this respect." 


\section{Genus FRINGILLA, Linnæus.}

\section{CHAFFINCH.}

Fringilla calebs, Linnæus. S.N., i., p. 318 (1766).

\section{Chaffinch, Boys, 1792.}

The abundance of the Chaffinch in Kent is well know to all lovers of birds, and the observations on the movements of this species during the autumn and winter of 1905.6 may help towards the supposed parting of the males and females during that season. From October 10, the Chaftinches were found all over the districts visited, especially in Romney Marsh, and the slopes overlooking that area. The males and females were equal in numbers and generally in pairs. It was not until November 17 that large flocks of both sexes were seen in the Marsh, which appeared to be all going south, and after their departure the pairs still remained throughout the winter. There is no doubt that the flocks were driven down from the north by stress of weather and went south, leaving those that were bred, and the old residents in these districts, still at their stations. During December, January and February, no diminution in either sex could be noticed, and the males began singing on March 6 , and no apparent increase in the numbers could be observed.

In the Zoologist, 1867, Mr. A. Clark-Kennedy states: "In the month of May, 1862, while staying at Frittenden, in Kent, I found a Chaffinch's nest in a laurel, with four eggs, two of which were of the usual colour, one with very few spots on it, and a fourth had 
no spots at all or lines of any sort whatever, but was of a deep, rich blue, not unlike a Hedge-Sparrow's egg."

In his notes on the birds at Rainham in 1868, Mr. F. D. Power says: "A great migration of these birds commenced about October 8, and continued every day throughout the month. This movement was always in a west-north-westerly direction, and most marked in the early morning, generally stopping about 10 o'clock. Flock after flock passed over in rapid succession, and at an average height of 40 yards, but on clear mornings they would be very high, in fact, only just visible, and only to be discovered by following the direction of their incessant chinkings. I noticed a similar migration last year about the same time, but not to such an extent."

Dr. A. G. Butler, in his remarks on the variation of nests, says: "In four nests of the Chaffinch, talien during the present year (1883), I observed little variation, excepting that one of them is thickly lined within with thistledown, and a second has the wall on one side very narrow and adorned with a single, very jaunty white feather; last year, however, I found a very aberrant nest, somewhat roughly constructed of roots and fibre, with very little adornment of moss and lichen, but a fair sprinkling of fine worsted; the interior is lined with thistle-down and hair, the latter being, as usual, most prominent."

In April, 1906, Mr. R. J. Balston observed the Chaffinch hawking insects from a fence at Bilsington, near the Priory, in the same manner that the Spotted Flycatcher does.

Notes on the Breeding of the Chaffinch. By Charles A. Witchell.

"Some years ago, a friend who had bred many hybrid Finches of different kinds, told me that hybrids could not 
be obtained from the Chaffinch, because that bird would not breed in confinement, a flight being necessary for the union of the sexes. This information, and the frequent exhibition of a swooping flight by a pair of Chaffinches, led me to conclude that the swooping flight might be really necessary to the breeding of the Chaffinch. My present purpose is to offer some remarks on the question whether a love-flight is necessary to the Chaffinch. By love-flight I do not mean the common straight cuckoolike flight of the male when he is leading a female from tree to tree, and flying with a constant and even succession of wing-beats; but I mean the swooping flight performed by both birds together, in which they are very near each other, if not actually in contact. During this swooping, the birds always utter the call-note which they particularly address to each other and to their young. It is a little soft sound, something like chirri pronounced very rapidly. In April and May this note may be constantly heard. But during the love-flight another sound is sometimes uttered, and this deserves very close attention. Perhaps the simplest mode of describing it will be to give a few instances of its occurrence.

"On April 19, 1898, near New Eltham (Kent), a male and female Chaffinch were uttering their call-note nearly overhead in an oak. They quitted the tree at the same time and swooped close together, passing within two yards of my head, and swerved up again into another. They were squeaking their call all the time, and during the flight, but at a moment when the birds were behind me, one of them uttered a brief repetition of a full low note, precisely like the low gurgling rattle which was uttered on a similar occasion by the Chaffinch at Strood. "On April 20, at a spot a quarter of a mile from the 
site of what occurred on the 19th (above described), two Chaffinches were calling in an elm tree. The female was shivering her wings and repeating the love-call very rapidly. A few yards distant from her a male was hopping from twig to twig, calling in the same manner. Both birds swooped, and during the flight the low, rattling cry was uttered exactly as it was yesterday. The low rattle is not always heard.

"On May 11 two Chaffinches swooped downwards together when passing from tree to tree, and during some portion of the descent they were very close together, breast to breast. They were all the time uttering the chirri very rapidly. One was certainly a female, and the other seemed to be a male. The foliage interfered with the view.

"On May 12 a pair of Chaftinches descended together from the top of an oak, swerved up again nearly to the full height of the tree (40 feet), and descended as before, uttering the call-note all the while.

"I have sometimes seen Chaffinches treading in a tree. The male then alights several times in succession on the female, meanwhile uttering the chirri, and at the last attempt, when about to quit the female, he utters the low, full, rattling note above mentioned, and immediately quits her and makes no further attempt for some time. It appears, therefore, that this full cry accompanies the act of coition, and, if so, it is important if the note is sometimes heard when the two sexes are swooping together. It seems to imply that coition may actually occur in the air.

"Near Eltham, in April and May, some of the male Chaffinches have a loud, single alarm-cry, zee, which can be heard through all the chorus of birds. This note is 
sometimes given in the song, but only at one particular part. It then takes the place of the hard penultimate note, wheat, and whenever given it ends the strain. It seems to me to be a survival from an earlier period. The Chaffinch seems to be losing all trace of this danger-cry, and to be developing instead the full love-rattle. The chirri and the "love-rattle," and the zee, uttered in succession, would constitute an excellent "slieleton" of the Chaffinch's song, and especially so if the first two cries were each repeated a few times" (Zoologist, 1898, pp. 195-197).

\section{BRAMIBLING.}

Fringilla montifringilla, Linnæus. S.N., i., p. 318 (1766).

Brambling, Boys, 1792 ; Kate (Kent).

The Brambling is only a winter visitant to the county of Kent, and during severe weather associates in large or small numbers with the Sparrows, Greenfinches and Chaffinches visiting the stubble fields and stockyards for food.

Pemmant, in the British Zoology, 1812, states: "I once had eighteen Bramblings brought to me in Kent which were killed with one discharge of the fowling-piece."

The Rev. J. Pemberton Bartlett, in his Ornithology of Kent, 1844, says the Brambling is "common in winter. I never knew them to breed in Fient, but suspect they occasionally do, as I have seen the old and young birds together in September."

The first observed by Mr. F. D. Power at Rainham was on October 2, 1868: "These passed over much in the 
same way as the Chaffinches, and were often mingled with them; few in comparison with the Chaffinches, but still more numerous than I have seen them before."

There are specimens in the Maidstone Museum obtained on March 22, 1887, at Marden, in Kient, by Mr. H. Kennard. It was not until March 6, 1906, that this species was obtained at Ivychurch in Romney Marsh, and on March 21 others were procured in Bourne Wood, Orlestone, after a snowstorm.

\section{Genus LINOTA, Bonaparte.}

\section{LINNET.}

Linota cannabina (Linnæus). S.N., i., p. 322 (1766).

Linnet, Boys, 1792; Grey Pate (Kent, for the young of autumn); Grey Linnets.

The Linnet is resident and abundant throughout the county and breeds freely in all the furze-covered wastes, but it does not restrict itself to furze; many pairs are found nesting in old hedges surrounding gardens and fields. During the autumn and winter they congregate in large flocks and mingle with the other finches in the stubble fields and rick yards.

The male Linnet is a very beautiful bird when he assumes the crimson breast of the breeding season, which is greatly reduced in colour in autumn and winter. It was not until May 25, 1906, that nests were found with fresh eggs in them, and these were placed in furze bushes, but nests were afterwards seen in some stunted thorn bushes in Romney Marsh. 
Dr. A. G. Butler gives the dates as follows: Rodmersham, Nay 27; Sittingbourne, May 28; Murston, May 29 ; and he says: "The nest of the Linnet is more variable than that of the Greenfinch. Of five nests which I took, only one had moss in its construction; this one is somewhat slightly built for the species, but the walls are strengthened with coarse straws, evidently selected from a dunghill. The second, excepting that it is not so deep, is not at all unlike a small nest of the Yellow Bunting; its construction is, however, decidedly firmer, and the grasses used in the walls are similar to what one usually sees in the nest of the Greater Whitethroat. The third nest is untidy, loosely put together, and has blackish, straggling roots projecting from the sides. The fourth is unusually deep, and is formed of roots, fibre and wool, with a few white hairs towards the interior. The fifth is a very ragged construction, formed of coarse bleached roots, lined with fine fibre and wool. No two of these nests, therefore, exhibit a similar aspect.

In his notes on the birds of Kent, 1896, Captain Boyd Alexander remarks that "Linnets resort in large flocks to the fallow fields, especially where charlock grows. 'The proverb which says that 'safety lies in numbers' might well be reversed in this bird. As soon as flocking takes place, the Linnets assume once more their shy habits, and carefully avoid our habitations, a trait also noticeable in other species of a similar timid nature. The delicate vermilion that smears the breast of the male Limnet is not attained till the second year. In immature birds a light chocolate colour takes the place of this."

During Mr. T. Hepburn's visit to the beach at Dungeness, in 1900, he found the "Limnets nesting in 
the holly bushes on the beach on May 10 and 14, and also a good many nests in the tussocks of coarse grass growing on some sand-dunes in the direction of Rye; some of these latter nests were made right on the level of the ground." In North Kent, he says: "In the winter Linnets seem to find food of some sort amongst the vegetation of the saltings, which is evidently to their liking, for numerous small parties of these birds are almost always to be seen there."

Mr. E. F. M. Elms, in his Ornithological Notes from New Romney and Littlestone, says: "I found a curious Linnet's nest (Grey Linnets they are called locally) in the side of a sand-bank, and ill concealed. The four eggs rested simply in the sandy cavity, and to prevent them from falling out, a frail barrier of bent and dead grass was constructed across the outer edge of the cup."

\section{MEALY REDPOLL.}

Linota linaria (Linnæus). S.N., i., p. 322 (1766).

The Mealy Redpoll is only an occasional and uncertain winter visitor to Kent, generally coming in flocks of various numbers, and keeping more or less to the higher hills in the county. There are specimens in the Maidstone Museum taken at Boughton Monchelsea, on March 20, 1879, by Mr. F. Smith. According to Mr. G. Dowker, Mr. C. Gordon obtained it at Dover. And Mr. J. E. Harting records " an unusual number of Mealy Redpolls that visited the south of England towards the end of 1895. At Dover the bird-catchers took as many as 200 in one day." 


\section{LESSER REDPOLL.}

Linota rufescens (Vieillot). Mem. R. Ac. Sc. Tor., xxiii., p. 202 (1816).

Lesser Redpoll, Boys, 1792.

The Lesser Redpoll is plentiful during the autumn and winter throughout Kent, especially so in Romney Marsh, where they obtain a large variety of wild seeds. In the summer it almost disappears, a few remaining in secluded localities for breeding. From the following notes it does not appear that the Lesser Redpoll's habits are confined to any particular position or surroundings for its nesting place.

In the Zoologist, 1864, Mr. Charles Wharton relates how he obtained the nest of this species: "On May 18, 1863, we found a Lesser Redpoll's nest at Tunbridge Wells; it was placed about 4 feet from the ground, in a furze-bush considerably overgrown with a bramble, in a small, unworked, and totally over-grown chalk-pit, on the south side of a hill. The hill was principally surrounded by wood and thicket, but was itself meadowland. The nest looked like that of a Linnet, but on going to it three days afterwards we were instantly undeceived. The male was singing, or rather twittering, in the small trees close by, and we soon recognised him as a Lesser Redpoll, with whose song in confinement we were well acquainted, as I had lately had one in my possession for some time. This bird of mine had died a few months previously, but not before he had paired with a hen Canary; and his only son I have now. We were further satisfied as to the identity, by the female allow- 
ing us to examine her within half a yard of herself, and almost to touch her on the nest. The nest subse. quently contained six eggs, exactly agreeing with the description in E. Newman's Bird's Nesting; three of these we still possess, the nest we left to the care of the parents. The nest was composed of dead grass and a little moss, and lined with horse-hair and a small quantity of cow's hair; there were no willow trees near, which may account for this strange lining."

During Dr. A. G. Butler's bird's-nesting in Kent in 1875, he found the "Lesser Redpoll's nest at Callum Hill, near Newington, May 31. I have not only seen and heard the Lesser Redpoll in Kent during the breeding season, but have on several occasions flushed the hen bird from her nest. Twice I obtained the nest with six eggs from grass tussocks growing upon narrow footpaths through marsh and pools of water at Murston, and once from a hawthorn on marshy land at Kemsley."

Mr. H. Lamb found the Lesser Redpoll breeding in 1893 in Maidstone Cemetery.

According to Mr. H. Elgar, of Maidstone, the Lesser Redpoll is not at all uncommon about that neighbourhood: "I found a nest with one egg in a gooseberry bush, and saw another in a damson tree at Linton a few years ago. There is a nest with five eggs taken from a. pine tree, now in the Maidstone Museum." Mr. MeadeWaldo says he "lhad seen a brood of young birds on June 24, 1905, in Kent, and about six weeks earlier ha lnown of several nests." 


\section{TIVI'TE.}

Linota flavirostris (Linnæus). S.N., i., p. 322 (1766).

Mountain Limnet, Boys, 1792.

T'he Mountain Linnet, or Twite, is only an autumn and winter visitor to Kent, leeping generally to the coast-line and marshes of the eastern portion of the county, very rarely coming inland.

Mr. WV. H. Power, in his Birds Observed at Rainham, says: "This regular winter visitant to the marshes made its appearance this year (1865) on October 2. These sober-coloured but lively little birds feed principally on the seeds of the Marsh plants growing on the 'saltings,' which are covered during springtides. They generally fly in small flocks, of ten or a dozen, and are very restless, especially in windy weather, when they constantly change their feeding-grounds. Occasionally they may be found associating with Linnets, from whose note their own is scarcely to be distinguished, except by a practised ear. On October 1, 1868, a flock arrived on the marshes, and became numerous by the end of the first week."

\section{Genus PYRRHULA, Brisson.}

\section{BULLFINCH.}

Pyrrtula pyrrtula (Limnæus). S.N., i., p. 300 (1766).

Throughout the county the Bullfinch is generally to be found in the wild bramble-covered wastes and thickets, always in pairs, and by no means abundant, but its 
shyness precludes the ordinary observer from seeing much of it. In winter and spring, before the leaves appear, it is more conspicuous, especially when the buds on our fruit trees begin to make their appearance in the gardens.

The nest of the Bullfinch is one of the lightest (next to the Turtle-Dove) constructions of our birds. When placed on a high branch of a whitethorn it is so slightly made of fine twigs, that it is transparent, and the eggs may be seen in it. In some instances it is so loosely put together that it falls to pieces on removal.

Mr. R. 'T. Filmer says it breeds freely in the thorn hedges along the railway in the Orlestone district. The nests bave been found in various positions, high up in thorn bushes and low down within 18 inches of the ground, sometimes in small open bushes, and at others in dense brambles.

\section{Genus PINICOLA, Vieillot.}

\section{PINE-GROSBEAK.}

\section{Pinicola enucleator (Linnæus). S.N., i., p. 299 (1766).}

The earliest and only record of the Pine-Grosbeak in Kent is that given by the Rev. J. Pemberton Bartlett in the Zoologist, 1844, p. 621, as follows: "The PineGrosbeak has been occasionally killed in Kent."

In the Zoologist, 1877, Mr. J. H. Gurney, jun., calls attention to the claim of the Pine-Grosbeak to be regarded as a British bird. After giving all the particulars respecting the Pine-Grosbeaks obtained in England up to 1877, he refers to those of Kent: "In Mr. Pem- 
berton Bartlett's notes on the ornithology of Kent, the reader is informed that the Pine-Grosbeak has been 'occasionally killed' in the county. Mr. Bartlett's informant was Dr. F. Plomley, who possibly may have referred to a pair of Pine-Grosbeaks in the late Mr. J. Chaffey's collection of Kentish birds, which were said to have been killed in England, but on whose authority is not known." "

\section{Genus LOXIA, Limmæus.}

\section{CROSSBILI.}

Loxia curvirostra, Limnæus. S.N., i., p. 299 (1766).

From the following records there is sufficient evidence that the Crossbill remains in Kent during the summer, and breeds in the county, and the earliest of these particulars appeared in Yarrell's British Birds, who says: "I have been favoured by the Rev. L. B. Larking, of Ryarsh Vicarage, near Maidstone, with a copy of an old MS., which refers to this subject in the following terms: 'That the yeere 1593 was a greate and exceeding yeere of apples; and there were greate plenty of strange birds, that shewd themselves at the time the apples were full rype, who fedde uppon the kernells onely of those apples, and haveing a bill with one beake wrythinge over the other, which would presently bore a greate hole in the apple, and make way to the kernells; they were of the bignesse of a Bullfinch, the henne right like the henne of the Bullfinch in colour; the cocke a very glorious bird, in a manner al redde or yellowe on the brest, backe, and head. The oldest man living never heard or reade of any 


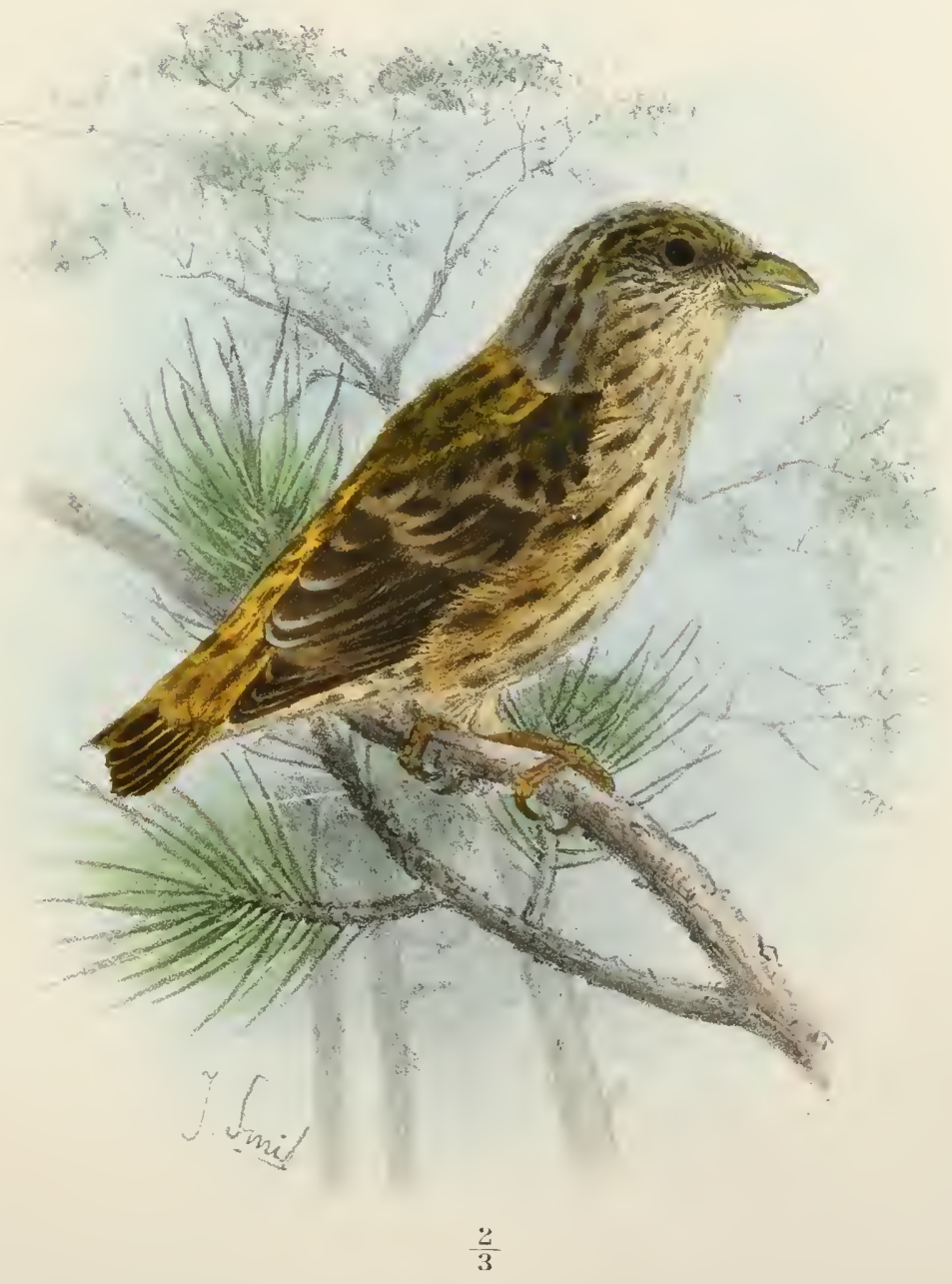

1 ;mat del et inth.

Bale ox leas isstu itd wan

CROSSBILL (Young)

LOXIA CURVIROSTRA, LInn. 

such like bird; and the thinge most to be noted was, that it seemed they came out of some country not inhabited, for that they at the first would abide shooting at them, either with pellet, bowe, or other engine, and not remove till they were stricken downe; moreover, they would abide the throweing at them, in so much as diverse were stricken downe and killed with often throweing at them with apples. They came when the apples were rype, and went away when the apples were cleane fallen. 'They were very good meate.'"

Professor Nervton, in the last edition of Yarrell's British Birds, states that "Lewin, in July, 1791, showed Latham a pair of old birds and a young one shot in his garden, while others of the brood still frequented the spot; and in August of the same year a hen-bird, with a bare breast as if she had been sitting, was shot at Erith, according to the naturalist last named, who also, in a contribution to the edition of Pennant's British Zoology, published in 1812, stated that a pair built a nest near Dartford, in Kent, but no eggs were laid therein, for the birds forsook it, owing to the too great curiosity of visitors."

In his Ornithological Notes of Kent, 1844, the Rev. J. Pemberton Bartlett states that "these curious and interesting birds visit the fir plantations in this neighbourhood (Kingston) in greater or less numbers nearly every year, appearing in considerable flocks some years in the autumn, while in others only a few stragglers are to be seen. I have shot several very fine-plumaged birds, but from their exceeding tameness it is difficult in a fir plantation to get sufficiently far from them to avoid blowing them to pieces. Although I have myself never found a nest of the Crossbill, I have ascertained from 
good authority the fact of their nidification in the fir plantations of Sir H. Oxenden, Bart., at Broome."

Morris, in his History of British Birds, 185.2, says: "This species builds in the fir plantations about Doddington, Kent."

In the Zoologist, 1868, Lord Clifton states that "a young Crossbill was caught in the garden of Cobham Vicarage during the summer of 1868."

Crossbill at Wingham.- "On July 27, I heard Crossbills as I was walking through the grounds close to my house, and almost immediately I saw a splendid old male with a female on a Lebanon cedar some 20 yards from me. The male bird shone like scarlet coral in the sun, as he swayed to and fro on the extremities of the branches. They seemed restless, and soon went off to an old larch, which they left again, and I lost them. Having never before seen Crossbills in the summer, I strongly suspected they had been breeding here. This morning I have just learned that some masons, who are at work about the house, picked up a young Crossbill at the edge of a pond where they were mixing their mortar; the bird was covered with mud and halfdrowned. It lived one day and then died. It was seen by my gardener and also by my gameleeper, to whom the men showed it. I think this is conclusive as to the fact that the Crossbill occasionally breeds in this country.IV. Oxenden Hammond, Wingham, Kent, August S, 1868.

"P.S.-A closer" enquiry refutes the persuasion I felt that the Crossbills had bred at my place. The bird caught (not the pair) was thrown away when it died; but I have seen the man who caught it, and he says it had red and green feathers. If I am right in thinking that 
no red feathers come till the first moult, it then was not a young bird, and my nesting theory fails. However, the presence of these birds in summer still would lead me to suspect that it bred." -W. O. Hammond (Zoologist, 1868, p. 1376).

Crossbills near Faversham.- "About the end of May I saw a quantity of these birds on some lofty fir trees; I and a friend shot about twenty of various colours; the greater part of them were males. Some were in the beautiful red plumage. After a few days these birds became very shy; I have had several brought to me since that time; the last I received-four birds, three of which were males-was on January 12."-A. Skinner (Zoologist, 1869, p. 1561).

Mr. R. T. Filmer says: "The only pair that I have ever seen was in the summer of 1871. At that time, in going to and from my work, I passed Springfield, Rye, the residence of the late Nr. Burrak. No doubt the birds nested in his grounds; they were daily seen by me for a long time."

In the Maidstone Museum there is a male and female obtained at Boughton Malherbe on July 25, 1887, by the Rev. H. A. Watson. This pair of birds was noticed in the Rochester Naturalist, October, 1887, by Mr. H. Lamb and also in the Zoologist of that year. And there is also a pair procured near Naidstone in November, 1889, by Mr. W. H. Day. There are also specimens in the Canterbury Museum from St. Alban's Court, Wingham, in Mr. WV. Oxenden Hammond's collection. The Rev. B. Delmar records it from Elmstone. Mr. Selby Smith procured two males and a female on December 8, 1903, in some fir trees at Barming, near Maidstone, which are still in his possession. A fully fledged nestling, just able 
to $\mathrm{fly}$, of this species, is now in the Maidstone Museum. It was caught alive by $\mathrm{Mr}$. H. Lamb in the Cemetery, Maidstone, on May 25, 1899, and preserved by Mr. H. Elgar. It appears that the late Mr. H. Lamb had been for some time on the watch for the breeding place of the Crossbills, which were frequently seen in that district.

Professor Newton, in the last edition of Yarrell's British Birds (vol. ii., p. 200), adds as a note: "Blyth says (Field Naturalist, i., p. 130) he was informed by a man who saw a brood taken near Sevenoaks, in Kent, that the nestlings when about half-fledged ' had the bill as much crossed as the adults.' But Blyth did not assert this on his own authority, and it is clearly a mistake."

\section{PARROT CROSSBILL.}

Loxia pityopsittacus. Bechstein. Orn. Taschenb.

$$
\text { i., p. } 106 \text { (1802). }
$$

The first notice of the Parrot Crossbill in Kent is given by Morris in his History of British Birds, 1852, who states that "a small flock was seen at Dodington, in Kent, in September, 1851." There is a skin of a female in the British Museum which was obtained at Bostal Common, Plumstead, in Kent, in January, 1868, and presented by Mr. H. Whitely, of Woolwich. According to Mr. H. Seebohm (British Birds, 18s4), the Parrot Crossbill "has been known to breed in Kent," but without the slightest clue as to how this information was obtained.

Mr. G. Dowker, in his Birds of East Kent, 1889, on the authority of the late Mr. C. Gordon, of Dover, gives East Kent as a locality in which it has been obtained, without data. 
None of these records appear in Mr. J. E. Harting's Handbook of British Birds, 1901.

\section{TWO-BARRED CROSSBILL.}

Loxia bifasciata, C. L. Brehm. Ornis, iii., p. 85 (18:27).

At a meeting of the British Ornithological Club held on February 18, 1903, Dr. N. F. Ticehurst recorded the occurrence, and also exhibited on behalf of the owner, " a female Two-barred Crossbill (Loxia bifasciata) for the first time in Kent. It was shot by Mr. H. Dale, on Cold Blow Farm, Woodchurch, on December 26, 1902. It was a dull grey-brown bird, with a slight tinge of yellowish-green on the flanks, and a poor specimen from having been lept a long time before being preserved" (Zoologist, 1903, p. 420).

\section{Genus EMBERIZA, Linnæus.}

\section{CORN-BUNTING.}

Emberiza mitiaria, Linnæus. S.N., i., p. 308 (1766).

Bunting; Boys, 1792 ; Nib Lark, Dowker.

This species is certainly not abundant in any part of Kent, and its solitary habits are well known, only being found in pairs during the breeding season. There are certain districts which appear to suit the habits of the Bunting, and there it may be observed regularly, but only in very severe weather does it come into farmyards for food with other finches. 
The Rev. C. H. Fielding records it from Higham, and it was obtained near Maidstone, in 1889, by Mr. E. Bartlett. Mr. G. Dowker found it in the Stourmouth district.

Mr. 'T. Hepbum obtained the eggs from the beach at Dungeness on August 14, 1900, and he "was told that they were common on the arable land of the marshes." In the Rainham district, according to Mr. IV. Prentis, "the Corn-Bunting is not very numerons as a species; generally to be met with on search being made; does not associate, as a rule, with other birds, breeds in the grass when the meadows are laid up for hay; also in pea-fields, singing its well-known note on the top of a bush or fence.

Dr. A. G. Butler says: "Although this species is tolerably common in Kent, I do not think I took its nest more than half-a-dozen times during the seventeen successive years in which I was an enthusiastic bird's nester, but as I had a strong objection to trampling down crops on the bare chance of discovering a nest, it is probable that I may frequently have passed within a few yards of the nest of a Corn-Bunting without being aware of the fact."

\section{YELLOW HAMMER.}

Emberiza citrinella, Linnæus. S.N., i., p. 309 (1766).

Yellow Hammer, Boys, 1792 ; Yellow Bunting.

Among our resident birds the beautiful Yellow Hammer is one of the most plentiful. It would be difficult to stroll along the country roads in Kent without noticing 
many pairs or flocks of them, according to the season. In the summer the bright yellow plumage of this bird is most attractive, and always conspictous. During the winter they gather in flocks and associate with the Chaftinches, Sparrows and others about the farmyards and gardens.

In his remarks on this species Dr. A. G. Butler says: "The Yellow Hammer (or Bunting) is a very abundant species, and in Kient one meets with it on every ramble; its brilliant colouring, unsurpassed by that of a Canary, and its funny little, never varying song, make it a general favourite. In partially cleared waste ground where there is short scrub of about a year's growth, its nest abounds, and the bird sitting close until one is almost upon it, and then flying off with no little bustle, constantly calls one's attention to the existence of a nest where least expected; it is, however, so conspicuous an object that there is rarely any difficulty in discovering it. The male Yellow Bunting in breeding plumage appears to vary considerably in beauty of plumage, the birds of Mid-Kent appearing almost like a distinct species from those of North-rest Kent, owing to the much greater development of yellow on the head. The female is much less yellow than the male (excepting in pairs netted in TVest Kent, which even in breeding plumage differ comparatively little). I have repeatedly tried to get hold of Yellow Hammers in brilliant plumage; but living on the borders of Northwest Kent, I find that the catchers invariably bring me dull-plumaged birds; the more intelligent have assured me that they have never seen a brightly coloured male Yellow-Hammer in the neighbourhood, which exactly agrees with my own experience. In the males of North Kent, on the other hand, all the males are especially fine 
in colouring." In East Fient the males assume the fine yellow plumage of those found in North Middlesex.

In 1900 Mr. T. Hepburn found the Fellow Bunting on May 10 and 14, "common and nesting in the furze bushes on the beach at Dungeness."

\section{CIRI BUNTING.}

Emberiza cirlus, Linnæus. S.N., i., p. 311 (1766).

From the few records of the occurrence of the Cirl Bunting in Kent, it is evident that it is far from being a permanent resident, and only occasionally found breeding in the county.

In his Ornithological Notes on the Birds of Kent, 1844, the Rev. J. Pemberton Bartlett states that the Cirl Bunting is "rare." In the spring of 1857, Mr. R. J. Balston shot five of these birds on the Warren at Boxley in Kent, and he noticed them again on March 19, 1859. In the Zoologist, 1872, Mr. D. 'T. Button, of Gravesend, writing on February 21, says: "The Cirl Bunting also occurs here (Gravesend) in flocks of from four to twelve."

In The Birds of Great Britain, 1873, Mr. J. Gould says "it is by no means scarce in Kent," \&c.

In Mr. G. Dowker's Birds of East Fent, 1889, it is considered a "common resident"; he also adds the localities and authorities as follows: Dover, C. Gordon; Elmstone, Rev. B. Delmar; Kent, Dr. F. Plomley.

Mr. O. V. Aplin, in On the Distribution of the Cirl Bunting (Zoologist, 1892), under the county of Kient, states that "Mr. W. O. Hammond, of St. Alban's Court, Wingham, writes: 'I have never myself seen the Cirl 
Bunting, but I have had specimens twice from MIr. C. Gordon, of Dover, obtained in that neighbourhood.'"

The Rev. C. H. Fielding, in 1893, added Ramsgate as a locality.

In 1894, Mr. W. Prentis, in his Birds of Rainham, writes: "There is only one patch in my district where the Cirl Bunting is to be found, about a mile of trees and bushes bordering the marshes in the vicinity of two old decoy ponds. I once found a nest containing eggs in an old dried-up decoy pond; it was built on the ground amongst the dead stems of the reeds."

In British Birds' Nests and Eggs, 1903, D1. A. G. Butler states that "Mr. Bidwell recognised in my collection a clutch of eggs of this species which I had taken at Iwade, near Sheppey, on June 5, 1877, as being unquestionably those of Emberiza cirlus."

\section{ORTOLAN BUNTING.}

Emberiza hortulana, Linnæus. S.N., i., p. 309 (1776).

This Bunting appears to be a very rare accidental visitor to this country, and the only records of its occurrence in Kent are briefly as follows: In the Zoologist, 1866, Lord Clifton, of Cobham Hall, writing on May 2, 1866, states: "On April 10, I saw here (Cobham, Kent) a Bunting, which, in my opinion, and in that of the Editor of the Field, was undoubtedly Emberiza hortulana It was sitting on an elder bush near a large pond, and remained there for some minutes. I at once distinguished it by its green head." 
Mr. G. Dowker, in his Birds of East Kent, 1889, adds this bird to his list as an "accidental visitor," and on the authority of the late $\mathrm{Mr}$. C. Gordon, it was obtained at Dover.

\section{REED-BUNTING.}

Emberiza schænichus, Linnæus. S.N., i., p. 311 (1776).

Reed-Sparrow, Boys, 1792.

In all the large reed-beds on the marshes in Kent the Reed-Bunting is generally to be found, but it is not an abundant species. In the summer and breeding season they keep in pairs, and in antumn and winter they may be seen in small family parties in the low-lying districts. Occasionally they are found in inland districts. Captain H. W. Hadfield notes the Reed-Bunting as having been shot on February 14, 1857, at Tonbridge, in Kent, and Lord Clifton mentions that, "on December 28, 1868, I was surprised to see a male Black-headed Bunting in a dry coppice, the last place in which I should have expected to see one. The nearest water to the woods is the Medway. On January 6, 1869, I saw a Blackheaded Bunting at some distance from any water."

This species is included in the following districts: Higham, Rev. C. H. Fielding; Bethersden, Captain J. D. Cameron. It is a constant resident, according to Mrr. G. Dowlier, in the Stourmouth district. At Orlestone, Romney Marsh, and in the surrounding country it is not uncommon. On May 10 and 14, 1902, Mr. T. Hepburn found it "nesting in some numbers in many places near 
water on the beach at Dungeness. Some of the nests found at this date contained hard-set eggs, and all of them showed signs of incubation. The nests were, as a rule, within 12 inches of the ground, in the rank grass and rushes; two of them were right on the ground. The nests are rather loosely constructed of grass, with a slight lining of hair." In May, 1902, Mr. E. F. M. Elms, in his Notes on the Birds of New Romney and Littlestone, "found a nest of this species, containing five typical eggs, built amongst the grasses of a ditch-bank, and within a few inches of the water-level." Dr. A. G. Butler says he had "seen individual examples from time to time not far from Canterbury," but he received "a nest from Mr. IV. Drake which had been found on the saltings at Kemsley, near Sheppey."

This species is included by Mr. Walter Prentis in his Birds of Rainham, under the heading of Black-headed Bunting (Emberiza melanocephala, Scopoli), which is an error.

Our Reed-Bunting (Emberiza schœniclus, Linn.) was by older authors called the Black-headed Bunting, and it was not until the discovery of the accidental occurrence of the large Black-headed Bunting (Emberiza [Euspiza] melanocephala, Scopoli) in England, that it was found necessary to fall back on the old English name of ReedBunting, or Reed-Sparrow, for our resident species. 


\section{Genus CALCARIUS, Bechstein.}

\section{JAPLAND BUNTING.}

Calcarius lapponicus (Limmæus). S.N., i., p. 317 (1766).

In this county, like all other parts of England, the Lapland Bunting is only an accidental visitor, being driven down from its northern home during the autumn and winter owing to the severity of the weather.

On February 28, 1867, Mr. J. Jenner Weir wrote to the Zoologist stating that a Lapland Bunting had been obtained at Lewisham in Kent: "This very rare straggler was captured, during the late severe weather, in Lewisham brickfields, near the Lewisham Road. The specimen is a male in the winter plumage, the velvety black beginning to show a little on the head and breast. The bird is very lively, and though the lark-feet would suggest a different habit, appears to prefer perching to resting on the ground. I may add that it showed its affinity to the Buntings by descending when caught to the call of the Common Bunting." Mr. G. Dowker records this bird at Dover on the authority of the late $\mathrm{Mr}$. C. Gordon, and at Folkestone on that of Mr. H. Ullyett.

In the Zoologist, 1883, Mr. W. Oxenden Hammond records the capture of a Lapland Bunting in the neighbourhood of Wingham in Fient: "The bird-catcher had taken what he termed an 'Ortolan,' but which was, indeed, a Lapland Bunting in its winter dress." 


\section{Genus PLECTROPhANES, Meyer.} SNOW-BUNTING.

\section{Plectrophanes nivalis (Linnæus). S.N., i., p. 308 (1766).}

Snow Flake and Tawny Bunting, Boys, 1792.

The Snow-Bunting, like the last-mentioned species, comes to this county during severe winters, and keeps generally to the sea-coast of East Kent.

The Rev. J. Pemberton Bartlett, writing in 1844, stated that it was "common in Romney Marsh."

In the winter of $18 \pm 7$, Mr. J. W. Hullie shot a SnowBunting at Deal, and on November 4, 1848, he shot another out of a small flock on the beach. Both were in the plumage of the Tarwny Bunting.

Mr. J. Jenner Weir, writing on February 28, 1867, says: "I was fortunate enough to obtain this morning a most beautiful specimen of the male Snow-Bunting; the bird is in variegated plumage of spring, is very healthy and active, and I trust will form an interesting addition to my aviary."

There are specimens in the late Mrr. W. Oxenden Hammond's collection in the Canterbury Museum, procured at Dover, but according to his note in the Zoologist of 1883 , he secured several specimens in the beautiful white plumage in the neighbourhood of Wingham in November, 1882.

It is an occasional visitor, according to Mr. G. Dowker, to the Stourmouth district, and also to the Rainham Marshes, according to Mr. W. Prentis.

In Mr. T. Hepburn's Birds of North Kent, he says: 
"Upon one occasion only, January 31, 1903, I followed and watched a flock of fifteen Snow-Buntings feeding in the grass on the river-wall. When flying away the white feathers in the wings and tail were so conspicuous as to make them appear to be almost entirely white. The note they uttered when flying was something like the twitter of the Greenfinch."

\section{Family ICTERIDÆ.}

\section{Genus AGELæEUS, Vieillot.}

\section{RED-WINGED STARLING.}

\section{Agelcus phaniceus (Linnæus). S.N., i., p. 161 (1766).}

The only occurrence of this species in Kent was first recorded by Mr. J. E. Harting in his Handbook of British Birds, 1872, who states that "Mr. J. H. Gurney, jun., informs me that he saw this specimen while in the hands of a bird-stuffer at Rye for preservation; it was lilled at Romney, in Kent, June, 1864, or 1865." It is also included in the last edition (1901) of that work. Professor Newton also adds it to the last edition of Yarrell's British Birds, and Mr. G. Dowker included the same bird in his Birds of East Kent. 


\section{Family STURNIDÆ. \\ Genus STURNUS, Linnæus. \\ STARLING.}
Sturnus vulgaris, Linnæus. S.N., i., p. 290
(1766).

Stare or Starling, Boys, 1792.

The Starling is extremely abundant all over the county. In the spring they separate into pairs for the breeding season, and in the autumn and winter they may be seen in large flocks in the pastures, especially among the sheep.

It is very amusing to see these wonderfully active birds searching the lawn and garden for food for their young, probing, as they do, every hole or crevice in the ground for any living insect or worm.

Mr. Morris mentions that Mr. Chaffey, of Doddington, Kent, has in his possession two of these birds, pure white, shot in the Isle of Sheppey. A pure white Starling was seen for some time in the Orlestone district, and then disappeared.

In the Birds Observed at Rainham, 1865, Mr. WV. H. Power writes: "A large flock of these birds continually waged war with some Kestrels for possession of the roof of a shed on the marshes, and very often succeeded in driving off their adversaries. On November 11, 1864, near the same place, I saw, in company with a flock of Starlings, a perfectly white one. Several times during the course of the day did I try to get within range, but was always unsuccessful."

In the Zoologist, 1888, Mr. F. H. Parrot mentions the 
"umrecorded habits of the Starling"; he says: "Whilst sailing on the Thames just below Erith, on June 3 last (1888), I was surprised to see some Starlings flying close to the surface of the water, and picking up pieces of bread floating there. When one had secured a piece, it immediately made for land to eat it. I also noticed the other day a Starling hawking for insects in much the same manner as the Martin, flying around it; so that Starlings not only imitate other birds' notes, but also their habits." Starlings appear to be very foud of sitting on the outside dead branches of large elm trees and hawking like Flycatchers; a great many were observed on one tree catching the winged ants which were migrating.

Starlings during the breeding season will take possession of every available position they can find for their nests, and if possible, will stop a chimney, or the head of a rain-water pipe, and when practicable, will get under the roof, to the annoyance of the household. A thatched roof affords a grand opportunity for the nesting place, but as a rule they generally keep to the habitation of man.

Mr. R. J. Balston once found a Starling's nest in a wooden case of a pump, the house being uninhabited at the time. At Boxley Abbey he observed these birds feeding their young, May 12, 1872; food was taken twelve times during a quarter of an hour-1.45 to $2 \mathrm{p} . \mathrm{m}$. -and excreta was removed about three times during that period. Again, on the 13th, from 5.30 to 5.45 p.m., food was taken five times. On the 17 th he watched two nests from 4.15 to 6 p.m.; food was taken to the nest already mentioned five times, and to the other seven times, excreta was removed once from each during that time. 
Genus PASTOR, Temminck.

\section{ROSE-COLOURED PASTOR.}

\section{Pastor roseus (Linnæus). S.N., i., p. 294 (1766).}

Although an accidental or occasional visitor to Kent, the Rose-coloured Pastor has been taken, and also observed many times, in the county, but it is doubtful whether it has ever bred here.

The Rev. J. Pemberton Bartlett, in 1844, records one specimen in Dr. F. Plomley's collection, which is probably the one now in the Dover Museum, but like all these specimens without data; and like those at Canterbury the records are retained by the departed donors, and nothing is done towards even a label with what little is known about them.

In the Zoologist, 1857, the Rev. C. W. Shepherd wrote, saying: "I have a Rose-coloured Pastor, which was shot at Frindsbury, near Rochester; it was shot in the summer, in a cherry orchard, out of a flock of Starlings." There is a specimen labelled Kent in the Maidstone Museum, without data, presented by Mr. G. Simmons. Nr. W. Prentis records that one was shot by a labouring man near Maidstone on the Tonbridge Road, in the year 1863 ; perhaps this refers to the above example.

In the Birds of East Kent Mr. G. Dowlier says: "Another rare visitor, the Rose-coloured Pastor, was shot by Mr. Hammond at St. Albans, Kent, in 1887, and another specimen had been obtained from Wye."

Rose-coloured Pastor in Kent.- "I think I may with certainty record the occurrence of a Rose-coloured Pastor here in January last (1889). It was seen in company with some Fieldfares, and from the description given to 14 
me, the observer being very near the bird, I have not a doubt as to its identity; the rose colour was conspicuous, but the black on the head and wings was less so ; the breast was described to me as "a most beautiful rose," and the " head above the eye dark." The bird was also described as smaller than the Fieldfares with which it was feeding. About mid-summer, 1888, a young Pastor, with the immature grey-brown plumage of the first year, was killed at Godmersham, some six or seven miles from Canterbury, and was at first taken for a Starling, but subsequently identified by Mr. Gordon, of the Dover Museum, who set it up. I saw this bird, and it was most certainly a Pastor. The occurrence of these two birds in comparatively the same neighbourhood in the same year, one quite immature, the other having passed the autumn moult, seems to point to their having been bred in the locality; at least this would be a reasonable surmise if the rose feathers appear after the first autumn moult. Some years ago I obtained a fine specimen of the mature Pastor in very nearly the same neighbourhood; it was shot in a garden while eating cherries."- WV. Oxenden Hammond, Wingham, Kent (Zoologist, 1889, p. 184).

In the Zoologist, 1901, Mr. L. A. Curtis Edwards records: "A fine adult male Rose-coloured Pastor was obtained on May 14 last (1901), near Appledore, in Romney Marsh, Kent. It was sent for preservation to Mr. G. Bristow, to whose kindness I am indebted for the privilege of examining the specimen in the flesh." It was reported that a Rose-coloured Pastor was seen about the first week in April, 1906, not far from Ham Street, Orlestone. 


\section{Family CORVIDÆ.}

\section{Genus PYRRHOCORAX, Vieillot.}

\section{CHOUGH.}

Pyrrhocorax graculus (Linnæus). S.N., i., p. 158 (1766).

\section{Red-legged Crow, Boys, 1792.}

It is very evident that the Chough, or Red-legged Crow, became extinct on the Kentish coast years and years ago.

The only traceable Kentish specimens at present known to exist are as follows: One in the Maidstone Museum, labelled Kent, presented by Mr. G. Simmons, which must be very old; and one in the Exeter Museum, from Kent, the bequest of the Rev. Bower-Scott. Neither of these two birds have any data attached to them, therefore it is very difficult to state for certann whether they are genuine Kentish birds.

Professor Newton, in the last edition of Yarrell's British Birds, gives the earliest history of the supposed existence of the Chough in Kent; he says: "Merrett, in 1667, speaks of it as found 'in omnibus oris maritionis a cornubia ad Doroberniam,' meaning, no doubt, Dover; but it may be noted that another Dorobernia, the city of Canterbury, bears Choughs in its arms."

Pennant, in his British Zoology, 1776, states: "The Chough is found in small numbers on Dover Cliff, where they came by accident. A gentleman in that neighbourhood had a pair sent him as a present from Cornwall, which escaped and stocked those rocks."

Professor Newton again remarks that "no date is given, but as the passage is not in his earlier editions, we 
may infer that the work was recent. Merrett's testimony, which was possibly unknown to Pennant, induces the opinion that he was misinformed, or else that his statement refers to a restoration of the species to its old haunts."

In the Zoologist, 1844, the Rev. J. Pemberton Bartlett, in his Ornithological Notes on the Birds of Kent, says: "These birds are still rarely to be met with in the neighiourhood of the cliffs at Dover, where in the time of Shakespeare they were wont 'to wing the midway air.' But there is every probability that the hissing and roaring of engines and railway trains will speedily and for ever scare them from their ancient haunts."

There is no doubt that both the references made by Shakespeare to the "Crows and Choughs" are meant for the Jackdaw. So great an observer of Nature as Shakespeare would never have omitted the red bill and legs. Therefore, the quotations belong to the grey-naped Jackdaw. In Mr. J. E. Harting's last edition of the Handbook of British Birds, 1901, he states: "In the Zoologist for September, 1893, I have shown that the 'russet-pated Chough' of Shakespeare ('Midsummer Nights' Dream,' iii., 2) was not the red-billed Chough, but the grey-pated Jackdaw. 'The latter was commonly called Chough, and russet with some writers meant grey ; the head of the Chough, like the rest of its body, is perfectly black." 


\section{Genus NUCIFRAGA, Brisson.}

\section{NUTCRACKER.}

\section{Nucifraga caryocatactes (Linnæus). S.N., i.,}

$$
\text { p. } 157 \text { (1766). }
$$

The Nutcracker is an extremely rare and accidental visitor to this county, and up to the present time only four instances of its occurrence in Kent are on record.

The first is that which Latham mentions in his Synopsis, 1781, as " a mutilated skin of which is now in the house of an acquaintance of mine." There is an adult specimen in the British Musemm, labelled Kent, presented by Mr. IVilliam George.

The following record is given of the third specimen obtained :-

Recent Occurrence of the Nutcracker in Kent.- " Your readers will be interested to hear of the recent occurrence in Kent of the Nutcracker (Nucifraga caryocatactes), a bird sufficiently rare in this country to deserve notice. The specimen referred to was shot by me on November 17 (1885), near Eddington. I saw this bird two days before it was shot, and had good opportunity of observing its movements, which appear to partake of those of the Jackdaw and Magpie. It was flying from an elm tree to the ground, and raking among the fallen leaves with a sharp busy motion, quite undisturbed by the presence of myself and a friend, whose attention I called to the indifference which the bird displayed. Although I spoke very loudly, to try the effect, no notice was taken, and it was only the abrupt appearance of a fox-terrier on the scene that caused the bird to take refuge in the tree overhead. We were standing within 40 yards, and it 
allowed the dog to approach within a yard of it before taking wing."-Colonel C. Willmot, Eddington Cottage, Eddington, Tient (Zoologist, 1885, p. 480).

In the Standard of January 28, 1886, Colonel Willmot added the following note respecting the foregoing specimen: "I obtained it in Strode Park, Herne, the seat of Mr. Prescott-Westcar, and on examination it was found that, althongh the bird is called a Nutcracker, and presumably is a nut-eater, its stomach contained more specimens of small coleoptera than regetable or other matter."

The fourth specimen is recorded as follows: "Dr. N. F. Ticehurst exhibited at a meeting of the British Ornithologists' Club, on January 18, 1905, a Nutcracher which had been shot on January 14, 1905, by a gamekeeper at Benenden, in Kent. It was a male by dissection" (Bulletin of the B.O.C., vol. xv., 1905, p. 31).

\section{Genus GARRULUS, Brisson.}

\section{JAY.}

Gamulus glandarius (Limnæus). S.N., i., p. 156 (1766).

$$
\text { Joy. }
$$

In all the old woods and plantations throughout the county the Jay still holds its own, generally keeping in pairs. Where the woods are not preserved they are more abundant and breed more freely, but in the pheasant preserves it has been found necessary to keep them under, on account of the destruction of the eggs and young of the game. 
Mr. W. H. Power, in his Birds Observed at Rainham, says the Jay is "common in the woods, but seldom venturing down near the river. They do not, however, lose in the slightest degree their habitual caution, but are ever on the alert, the first thing heard on entering an orchard being their derisive chatter, uttered as they take themselves off."

\title{
Genus PICA, Brisson.
}

\author{
MAGPIE. \\ Pica pica (Limneus). S.N., i., p. 157 (1766). \\ Hagister (Kent), Swainson.
}

The Magpie is rather a local bird, although in some districts it is plentiful, and it appears to prefer the large marshes in the county. In years gone by it was extremely common along the Kentish coast, especially about the labourer's' cottages in the Marshes. Only a year or two back in one district in Romney Marsh some twenty or thirty were lilled on account of their depredations, but in the more inland districts they are less frequent and only found in pairs, breeding in the more secluded old woods.

MIr. G. Dowker, in his Birds of East Kent, says: "I have a word to say for the Magpie, so persecuted by sportsmen and farmers, that it is a wonder he is not exterminated. True, he will rob the hen of her brood, and appears insatiable in his appetite for a time; but it is only while rearing their young that they are so destructive; at other times they are great destroyers of mice and insects." 
In 1902, when collecting at New Romney and Littlestone, Mr. E. F. M. Elms remarks: "Rommey Marsh is hardly suitable to the requirements of the crafty Magpie, as, comparatively speaking, it is a somewhat treeless district; but nevertheless a pair were observed, and the nest located. This was built about $S$ feet from the ground in the thickest part of a hedgerow rumning along the side of the road, and was composed of stontish twigs and the usual formidable thorns. To those who once believed in the two species of Magpies-the one that built in a tree, and the other that placed its nest in a bush-this present case would doubtless furnish substantial evidence of a difference. The nest under consideration contained four of the usual eggs disposed symmetrically around a large stone."

In 1902 a hundred Magpies were killed by Mr. Balston's keepers in the neighbourhood of Ham Street and Ruckinge, out of which seventy were destroyed on the borders of the Marsh.

Genus CORVUS, Limnaus.

$$
\text { JACKDA II. }
$$

Corvus monectula, Linnæus. S.N., i., p. 150 (1766).

Daw.

'I'bere are few old castles, churches, or large hollow trees, that are not made the home of the Jackiaw, in fact, he will make himself at home among the chimmeys of our large modern buildings in the county towns and villages. The bird is plentiful in certain districts which 
possess the necessary positions for its bulky nest, and when once it takes a fancy to a chimney, it will carry a barrow full of material to stop it up. The Jackdaws associate in large numbers in all the chalk-pits and chalk-cliffs in Kent, and it was from the Dover Cliffs that Shakespeare, observed this bird, and wrote the following lines :-

"The Crows and Choughs that wing the midway air Show scarce so gross as beetles."

$$
\text { -King Lear, Act iv., Sc. } 6 .
$$

Writing on the audacity of Jackdaws, Mr. WV. Oxenden Hammond says: "They abound here (Wingham) in the old trees, and have become so mischievous, destroying all the Blackbirds', Thrushes' and other eggs (to say nothing of game), that, rather reluctantly, I ordered their number to be reduced. The next day, or nearly so, my shepherd saw a Jackdaw plunder a Kestrel's nest near the house, that I have each year tried to protect, and take the eggs. The bird dropped one, and in order to identify it, I directed the man to bring me the broken egg-shell, which he did, and I found it to be a Kestrel's. 'This attack on a hawk's nest, although the Kestrel is not a bold bird, still shows a Jackdaw's andacity to be considerable."

These birds build in the large chalk-pits on Boxley Hill, and they became very troublesome in the eggstealing line. 'They used to steal the wild-fowls' eggs from the pond at Boxley Abbey. They breed in all the old churches in and about Maidstone, and they have not overlooked Canterbury Cathedral. According to $\mathrm{Mr}$. T. Hepburn, there is a "thriving colony in the ruins of Camber Castle." 


\section{CARRION-CROTV.}

Corves corone, Limnæus. S.N., i., p. 155 (1766).

Crow, Boys, 1792 ; Black Crow.

The Black or Carrion-Crow is decidedly a scarce bird in most parts of Kent, and being an extremely wary bird, keeps out of gumshot. They have been observed for some time, but only in isolated pairs, and do not associate with the Rooks or Jacklaws. They generally select a place for the nest in a secluded spot, and in which they feel secure. A nest was built in a large elm tree on the banks of the Royal Military Canal in Romney Marsh, and Mr. R. T. Filmer says a pair, in 1900, built a nest close to his house at Orlestone. Mr. H. Lamb states that a pair nsed to breed at Langley, near MIaidstone. Dr. A. G. Butler obtained the eggs at Iwade, near Sheppey, and also at Murston, in 1875.

There is no doubt respecting the destructive habits of this bird, hence its rarity.

\section{HOODED CROW.}

Corvus comix, Limmeus. S.N., i., p. 156 (1766). Hooded Crow, Boys, 1792; Kentish Crow, Grey Crow, Queenborough or Royston Crow, Dun Crow.

This species is only an autumn and winter visitor to the county of Kent, and appears to keep generally to the seashore and the large river banlis of the county, rarely going inland, unless driven by the scarcity of food. According to Mr. W. H. Power, "this crow is exceed- 
ingly common during the winter months, arriving about the second week in October, and leaving again early in the spring, although my brother once saw one as late as April 18. These birds roost at night in the woods, and at first streak of dawn wend their way to the marshes, where they generally remain until dusl. In foggy weather they take to the orchards, and are then somewhat less difficult to approach. A 'sprat field' is, however, their delight; here they gorge themselves; indeed, they are not at all particular in their food, little coming amiss to their stomachs, from live crabs to dead sheep. In $1868 \mathrm{Mr}$. F. D. Power observed one on October 1, and by the end of the second week they were numerous." Lord Clifton states that on October 6, 1876, he "saw the first Hooded Crow here (Cobham, Kent) three days earlier than I ever saw one before." It is a regular visitor to the Stour Marshes, according to Mrr. G. Dowker. It was obtained at Pluckley on October 12, 1897, and this specimen is now in the Maidstone Museum. It is included in the birds of Bethersden by Captain J. D. Cameron. It is plentiful in winter on the banks and marshes of the Medway below Aylesford, according to Mr. H. Elgar. It was not until October 19, 1905, that the Hooded Crow was seen near Lympne.

Mr. T. Hepburn, in his notes on the birds of North Kient, states that the "earliest date I have noted of seeing the Hooded Crow in the autumn is October 21, 1900, and the latest date in spring is April 21, 1900 ; but a closer observation than I am able to keep would no doubt give more exceptional dates. It is a common sight to see both Hooded and Carrion-Crows feeding out on the mud-flats, amongst Gulls and other birds, at low tide." 


\section{ROOK.}

Corvus fingilegus, Linnæus. S.N., i., p. 156 (1766).

$$
\text { Rook, Boys, } 1792 .
$$

The Rook is extremely abundant throughout the county, and in the autumn and winter may be observed in hundreds on all the pastures, especially among the cattle and flocks of sheep. During this season they travel long distances from the rookeries and visit the marshes and sea-coast, but in spring they usually keep to the land surrounding the rookeries until the young are able to follow their parents. There is scarcely a park or private plantation in Rent withont its rookery, which are too numerous to be given here. They nearly alrways select the highest elms for the nests, and in a position of perfect safety, but occasionally they have been known to take possession of large isolated Scotch fir trees.

Mr. A. Skinner (Zoologist, 1869) mentions a variety of the Rook: "As I was walking round Chilham Park one day in the summer (1868), I perceived something black on the road, which proved to be a dead Rook with a white throat, besides the ordinary black plumage.'

A curions instance of the Rooks having neglected a certain district, and then taking it up, is given by $\mathrm{MI}_{\mathrm{r}}$. G. Dowker in his Birds of East Kent: "The Rools have of late taken up their abode in this parish, why or wherefore they never came before I cannot imagine, there being a toll of elm trees on the glebe next the church, which the late Rector liept most carefully secluded ; and he was most anxious to get a rookery. However, the Rooks never came till just after his death, a few year's ago. With the new Rector came the Rooks, though 
they do not receive half the protection they mould have formerly enjoyed."

Mr. W. Prentis, in his Birds of Rainham says: "Taking my farm as a criterion of the Rook's usefulness, throughout the summer I see but few, but when I begin to sow the wheat in the autumn they come by thousands, and continue doing so, off and on, throughout the winter, leaving soon after the barley is sown in the spring. Now if those persons who support a rookery, and where Rooks superabound, were to feed them with several sacks of corn per day, they would then know the worth of the depredators they harbour and encourage." In the Fauna of the "Cedars," Lee, Kent, J. F. Green, Esq., gives the following: "The rookery here is a very ancient affair. The Rooks commence to repair their nests in February, which through the winter months have been used by 'Iits and other small birds to roost in. I could relate plenty of stories about their peculiarities, but will confine myself to two. In February, 1901, we started hockey for the first time on the cricket-ground. The large elms overshadowing the ground contained the usual Rooks' nest; but the busy occupants failed to appreciate this innoration, and moved all their nests bodily across the railway to the other side of the grounds. The Rooks (with other birds) are fed every morning on the "Cedars" lawn. One Sunday this was forgotten, and I saw a small detachment of the boldest spirits march up to the drawing-room window and commence tapping. A sort of gentle reminder! With them I often see, and still oftener hear, a pair of Carrion-Crows."

Notes on the Rook (Corvus frugilegus)._ "Tonbridge, March 22, 1857: There is a rookery in some lofty elm trees close to the town. Observed this morning their 
manner of building, one rook remaining to guard the nest whilst its partner flew off in search of building naterial; but I remarked that, instead of picking up dead twigs or sticks, it set to work to break off green ones. After having secured two, which it retained in its beak, it endeavoured to break off a third, but failing in doing so, as it was not only a green but a strong twig, the Rook threw itself back so as to bring its whole weight to bear, not, lowever, relinquishing its hold of the branch on which it stood, extending its wings at the same time, so as to add force to the pull: by this means it eventually succeeded in dragging or slipping it off, although its utmost powers had previously failed in breaking it. There were two other nests on the same branch, one indeed, almost touching the first, and I counted about thirty in a more or less forward state, but few, I think, were complete; consequently, it would appear that rooks are rather backward with their building this season, as White tells us they begin as early as February 16; Macgillivray mentions the same date, and Markwich February 28. March 27: Had another look at the rookery this afternoon. Found the nests were beginning to malie more show. but, from the great clamour and commotion that prevailed, I am inclined to think few ont of the number can yet be ready to receive eggs. I witnessed several slinmishes, besides a general assault made on a half-finished nest, which was not only covered with the assailants, but surrounded by them for some time. I observed one of the unfortmnate Rooks defending its aërial castle most stoutly, indeed furiously, clinging to it with the greatest tenacity, never once quitting its hold, emitting, at the same time, an angry, hissing kind of noise, which might have been heard at a con- 
siderable distance. What the culprit had been about I could only conjecture, but probably it had been caught, or rather detected, in the act of robbing one of its neighbours, but as Roolis are notoriously a thievish race, I was not prepared for such a general and public display of virtuous indignation, proving, however, the old adage true, that there is even honour among thieves.

March 31 : In passing the rookery I observed the Rooks were as quarrelsome as ever, frequent fights taking place, even upon the nests, so that had they contained eggs they must, I think, have been either broken or thrown out. I noticed several Roolss, evidently paired, on the branches close to and immediately over the nests-a proof that they could not have contained their full complement of eggs, or one of the birds would have been sitting upon them. Rooks are exceedingly clumsy birds, for they even roll about in walking, and their oscillation on first alighting on the branches is very remarkable, and in flying into the trees they often miss the branch on which they had endeavoured to perch, thereby dropping several feet lower into the tree than they had intended; and even when seated they are a few seconds balancing themselves to and fro, with wings extended and their heads depressed. This awkwardness may, I think, partly arise from the great size and weight of the head and bill, as well as from the shortness and rigidity of the claws, which certainly appear better adapted for walling than for grasping the branches of trees."-H. IV. Hadfield, Tonbridge (Zoologist, 1856, p. 5682). 


\section{RAVEN.}

Corvus corax, Limmens. S.N., i., p. 15.5 (1766). Raven, Bors, 1792.

The scarcity of the Raven in Kent is not to be wondered at, considering its depredations; all who know the bird are its enemies, and its chance of escape when found is very limited. During the last century it has become almost extinct in the county, and must now be looked upon as a rare visitor.

In the Topography of Maidstone, 1839, it is noticed that "some of this species at intervals make their appearance at different places in this neighbourhood, as is their habit elsewhere, and after a time disappear."

Mr. J. J. Briggs, writing in Angust, 1852, says: "This bird I met with near St. Margaret's Bay, Kent, in June, 1852. I am told it breeds annually on the highest parts of the cliffs, generally on the same rock, but not on the same ledge."

Lord Clifton, in his notes on the birds at Cobham, Kent, September 4, 1868, writes: "In the same wood I heard and saw a Raven on September 3, 1868; it was the first I had seen for a long time; one ancient pair were shot on account of their annoying the Herons so much."

The Rev. C. H. Fielding, in his Hand-book of Higham, 1882, says: "It used to be found in the marshes, but is now probably extinct"; and Mr. G. Dowlier says: "The Raven is becoming almost as rare as the Chough in the Stourmouth district." They were destroyed at Cobham for attacking the Heronry. A pair were shot in Romney Marsh, near Lydd, some years ago, and are now in the 
collection of R. J. Balston, Esq. According to Mr. W. Prentis, "the Raven is by no means common, our shepherds proclaim eternal war against them." On April 19, 1906, a Raven was seen to come up from Romney Marsh, and pass over in the direction of Bilsington.

\section{Family ALAUDIDÆ. \\ Genus ALAUDA, Linnæus. \\ SKY-LARK.}

Alauda arvensis, Linnæus. S.N., i., p. 287 (1766).

The abundance and the song of the Sky-Lark is well known to all lovers of birds throughout the county. During the summer, what is more delightful than to sit down and watch and hear the Sky-Lark ascend on wing, singing its joyous song until almost out of sight.

In Kent, during the autumn, they collect in the marshes in large flocks and travel south, leaving many on the land. No doubt these are the birds that have bred in the locality, and remain throughout the winter, but not in large numbers.

They have been noticed to leave East Kent in the winter in large numbers and reappear about the second week of February.

On the afternoon of June 19, 1875, a Lark was seen to perch on a stake of an old hedge at Cuzinton Farm, Kent, and it was heard to sing while there.

Mr. J. Fremlyn Streatfield, of Chart's Edge, Westerham, records that on July 9, 18t5, " a Lark's nest was 
discovered in a field in which some cows, being tethered, had eaten the pasture close to it, but had left a tuft around it, in which the bird remained unharmed and unconcerned."

Dr. A. G. Butler writes: "The mother-bird displays considerable persistency in attending to her young, and is very careful in concealing her nest as much as possible. A remarkable instance of this came under my notice some years ago, when visiting the Isle of Sheppey. Happening to meet a shepherd, I asked him if he ever met with Larks' nests; he led me back about 3 yards, and pointed to a patch of water-weed at the edge of the path as a nest. I stooped down and found that the weed was regularly interlaced in the edge of the nest, over which it fell, completely concealing it."

In his ornithological notes from Romney Marsh, Captain Boyd Alexander states that " on June 16, 1896, two Sky-Larks' nests were found in a meadow, containing four and two eggs respectively, perfectly whitea variety which is identical with the texture of the Kingfisher's egg. The nest of four eggs was quite good, but the other had been deserted."

While collecting on the beach at Dungeness in 1900, Mr. T. Hepburn says : " May 10 to 14: The Sky-Larks were nesting everywhere in great numbers, even right out on the open beach. July 20: Found a nest with two eggs in it, and was told of one being found the previous week containing eight eggs. May 18, 1902: Sky-Larks exceedingly numerous; in fact, this species, the Meadow-Pipit and the Wheatear were the most numerous birds in this district. Found a Sky-Lark's nest built in a hollow among a heap of stones on the roadside, containing four much incubated eggs. This 
species nested freely in convenient natural depressions sheltered by the grass growing at the sides of the road. In the aftermoon, whilst walking at the side of the road, I almost trod on the parent bird, who flew up from my feet, disclosing four newly hatched chicks. A repetition of the same thing occurred a few yards further on, the nest containing three fresh eggs; and yet another with four fresh eggs. Besides these, several empty nests were discovered."

In the Zoologist, 1847, Mr. Edward H. M. Sladen drew attention to an article which appeared in the Kentish Gazette, February 2, 1817, respecting a new species of Lark, which had been found near Margate, and described under the name of Alauda isabellina by Mr. S. Mummery. These birds were merely buff or cream-coloured ordinary Sky-Larks.

\section{WOOD-LARK.}

Alauda arborea, Limnæus. S.N., i., p. 287 (1766).

The Wood-Lark is a scarce bird during the summer in Kent, and it does not appear to breed in any numbers in the county. From observations made they are more abundant during the winter, when driven down from the north.

Lord Clifton, writing to the Zoologist, 1867, says: "During the first severe snow here (Cobham) flocks of Larks were continually passing over the park. The birds I imagine to have been Wood-Larks. I never could find out that they settled anywhere; all I know is that they were continually passing over my head in a south-westerly direction; as they flew over me I noticed 
that they seemed short, compact birds, and that the tail was short-shorter, I should say, than any Sky-Lark's tail. The breast appeared to be of a pure white ground colour, the spots not being visible at such an altitude; while on the throat there was a very thick and distinctly marked cluster of dark red spots. I consulted Mr. Harting's book as to the distinction between the two species, and was tolerably satisfied as to my birds being Wood-Larlis; but what exactly gave me the idea of them was the figure of the Wood-Lark in Our Native Songsters. I saw one passing over on January 8, and two on January 14 (1868); one of the latter, which I nore particularly noticed, seemed to be very dark-coloured."

Mr. G. Dowker states that in the Stourmouth district the Wood-Lark "comes in flocks in the winter." On March 10, 1906, four or five of these birds were seen above Ruckinge, apparently on their return and going north.

In the Maidstone Museum there is a nest and egg procured by Mr. J. Coveney at Hollingbourne, Kent.

\section{CRESTED LARK.}

Alauda cristata, Limmeus. S.N., i., p. 288 (1766).

The Crested Lark is evidently a rare, accidental visitor to the county, and the only records of its occurrence in Kent are taken from the Zoologist, 1867, p. 1167. On June 1 Mr. M. Hutchinson wrote stating that he had seen a "Crested Lark" near Blackheath, and the sub. joined are particulars of the-

Supposed Breeding of the Crested Lark in Tient."Among the oological discoveries this year, none is 
perhaps likely to evoke more interest than the eggs of the Crested Lark (Alauda cristata), taken in Romney Marsh on June 7, and subsequently purchased by me at Steven's Auction Rooms. The recorded evidence of the breeding of this bird in England having hitherto been confined to one alleged instance, at Ibiston, near Cambridge, in 1881 (Zoologist, 1883, p. 178), ornithologists will doubtless be glad to hear of a well-authenticated case, the parent birds having been seen by Mr. Sydney Webb, as well as by Mr. George Gray, a well-known naturalist, at Dover. I quote from a letter addressed to Mr. Stevens by Mr. Webb on Mr. Gray's behalf, and sold with the eggs: 'Mr. Gray, of this town (Dover), who is an ornithologist and taxidermist, having been informed by some lads, who had been watching birds for him, that they had discovered a nest of eggs which they did not know, we were led to the spot, but only to find one young bird hatched out, one broken egg, and one addled; the latter you now have. Scarcely had the egg passed from hand to hand when one of the boys called out, "There's the old one; look at his top-knot!" And sure enough, we saw a living Crested Lark close to us. There could be no mistake, the long crest rechining backwards, Cranelike, quite unlike an ordinary Lark's raised crest.' It is curious also that the birds made a second nest, from which another egg was obtained early in August. This also passed into my hands."-C. A. Briggs (5.5, Lincoln's Inn Fields).

Mr. G. Dowlier states that a Crested Lark was obtained at Rainham, on the authority of the late Mr. C. Gordon, of Dover. 


\section{Genus CALANDRELla, Kaup.}

\section{SHORT-TOED LARK.}

\section{Calandrella brachydactyla (Leisler).}

Ann. d. Wett. Ges. f. d. ges. Nat., iii., p. 357 (1814).

With regard to the Short-toed Lark in Kient, which is, perhaps, one of the rarest accidental visitors, and the subject of some little doubt as to its occurrence in the county, it is well to note that Mr. J. E. Harting enumerates ten which, without hesitation, have been taken in England, therefore it is highly probable that the specimen referred to by Mr. Theo. Fisher in the Zoologist (188.5, p. 31) was a Kentish specimen. He says: "Passing, by chance, a bird-catcher's shop, I stepped in to ask the owner if he had ever caught any rare birds. He told me that in June, 1883, he had caught, near Orpington, in Kent, a peculiar Lark which no birdstuffer or bird-catcher of his acquaintance had been able to name. The bird died, but he had it preserved, and showed it to me, when I found it to be the Short-toed Lark, Alauda brachydactyla, Leisler. The bird-catcher liept it for some time, and it soon became accustomed to confinement, but, unfortunately, died soon after completing its moult. 'Its song,' he remarked, 'resembled that of a Skylark, but was more varied..",

The only other record is given by Mr. G. Dowker in his Birds of East Kent, viz.: "I give this on the authority" of Mr. G. P. Saville, that a specimen was shot by $\mathrm{Mr}$. W. Fleet, at Wells Court, Blean, in 1886." 


\section{Genus MELANOCORYPHA, Boie.}

\section{WHITE-IVINGED LARK.}

Melanocorypha sibirica (Gmelin). S.N., i., p. 799 (1788).

"On January 27 a male, and on January 28 a female, of this species were shot by a man named Ward at Woodchurch, in Kent, and subsequently exhibited by Dr. N. F. 'Ticehurst at a meeting of the British Ornithologists' Club (Bulletin of the B.O.C., xii., p. 50); a third individual was seen but not procured. These were the first records of this bird in the county of Kent.

" At a meeting of the British Ornithologists' Club, held on October 22, 1902, Dr. N. F. Ticehurst exhibited a male White-winged Lark (Alauda sibirica). This was the third of the birds mentioned above as having been with the pair that were shot at Woodchurch in Kent. It was constantly seen there, but being very wild was not obtained until March 22, 1902. It differed from the male previously recorded in being brighter on the head and wing-coverts and in having much more white on the throat and breast."

\section{BLACK LARK.}

Melanocorypha yeltoniensis (Forster). Phil. Trans., lvii., p. 350 (1767).

During the severe weather of January, 1907, the unexpected occurrence of the Black Lark (Melanocorypha yeltoniensis) in Kent was made known by Mr. C. B. Ticehurst, who exhibited a male and female at a meeting 
of the British Ornithologists' Chub, held on February 20, 1907. He wrote: "The female was brought to me in the flesh on February 2, 1907, by Mr. Bristow, who bad just received it by post from Lydd, Kent, where it had been shot on January 31. It was accompanied by a male and two females, and the man who shot it aimed at the male bird as being a stranger to him, but the shot lilled the female. Since these two were obtained I hear from my brother that another male was shot at Lydd, Kent, on February 18, and another at Rye, Sussex, on February 16, and that others have been seen" (Bulletin of the B.O.C., xix., p. 57, 1907).

\section{Genus OTOCORYS, Bonaparte.}

\section{SHORE-IARK.}

Otocorys alpestris (Linnaus). S.N., i., p. 289 (1766).

The Shore-Lark appears to be a frequent visitor to the coast of Kent, and many examples have been secured at various times during the autumn and winter.

In Yarrell's British Birds he states that "before November, 1838, I had heard of a pair that were obtained together on a down in Kent, the male only of which was preserved.

Occurrence of the Shore-Lark at Woolwich._. "A week or two ago I went into a small bird-stuffer's shop here, and whilst conversing with the owner he informed me that a workman in the dockyard at Sheerness had, during the cold weather last February (1S61), shot fire specimens of what he called the American Lark. Upon his describ- 
ing them, however, I made out that they could not be that species, being too small, having a crest on the head, and various other distinctions, by no means characteristic of the Anerican Lark. The man said that the only bird which he thought in any way resembled them was the Cirl Bunting; so I was somewhat curious to find out what these remarkable individuals really were. In my own mind I set them down as being the Shore Lark, if any species of Alauda at all; and as my friend kindly offered to get them for me to look at, I did not refuse, and a few days ago called on him again, when he showed me five specimens of Alauda alpestris, Linn. So I had guessed rightly. 'There were apparently two adult males, one female, and two immature or young birds ; all, except the latter, in very good condition. There is no doubt as to the fact of the birds being shot in the neighbourhood of Sheerness, as the person who killed them was quite unaware what he had shot, and only skinned them (in not a very scientific manner) because he thonght them pretty, uncommon-looking birds. I am not aware if any others were shot in Tient or elsewhere last winter." G. F. Mathews, July 16, 1861 (Zoologist, 1861, p. 7708). Shore-Lark in Captivity.- " I have in my possession a Shore-Lark (Alauda alpestris), which was taken in a net under the cliff near Dover. With the specimen of Richard's Pipit previously recorded in the Zoologist (S.S., p. 1458) as having been captured near here, it is intended to be added to our collection of Kentish birds. The bird is now to be seen in its cage in lively and healthy condition. The food given is canary and hemp seed, which it eats freely and thrives upon. It is a male bird, and I intend, if possible, to keep it alive, in the hope of hearing its song. The markings are very brilliant (see descrip- 
tion in Yarrell, vol. i., p. 402). I believe this is the first linown instance of the Shore-Lark having been captured alive in England.'-Charles Gordon, November 23, 1868 (Zoologist, 1869, p. 1513).

Writing to the Zoologist in 1883, the late Mr. W. Oxenden Hammond says: "Having heard that a birdcatcher in this district had been catching some ShoreLarks in November last (1882), I went to his house to see them. He had then three, taken about two days before $m y$ visit, and these were supplemented by four more, seren in all, about a week later." Some of these specimens are now in the Canterbury Museum.

\section{Family CYPSELID E.}

Genus CYPSELUS, Tlliger.

STIFT'

C'ypselus apus (Limnæus). S.N., i., p. 344 (1766).

Swift, Boys, 1792 ; Screecher, Squeaker, and Screech-Owl.

The Swift is usually a late arrival in Kent, but after the warm weather sets in at the end of May they become very abundant in all the districts in which they have found suitable breeding places. These breeding places are, as is well known, generally in the roofs of old buildings, especially churches and lofty houses, around which these birds circle and gambol in their everlasting flight.

The following curious instances of the effects of the climatic changes of the atmosphere on the Swift are given by Mr. F. Smith in the Zoologist, 1856: "On Tuesday, July 8, I was at Deal; the early part of the 
day was warm, but a continuous dizzling rain fell ; this, however, did not prevent Swallows and Swifts from hunting after their prey much as usual. Towards evening a sudden atmospheric change took place; the thermometer fell rapidly; it became so cold that an overcoat was not uncomfortable. Sitting at the window, and amusing myself by watching the Swifts, which were very numerous, I was struck by observing that their flight was unsteady; they fluttered up against the walls of the houses, and I saw several even fly into open windows. Whilst observing these occurrences a girl came to the door to ask me if I wanted to buy a bat. She had heard, she told me, that I bought all kinds of bugs, and her mother thought I might want a bat. On her producing it, I was astonished to find it was a poor benumbed Swift. The crirl told me they were dropping down in the streets, and the boys were killing all the bats; the church, she said, was covered with them. Off I started to witness this strange sight and slaughter. True enough, the children were charging them everywhere, and on arriving at the church in Lower Street, I was astonished to see the poor birds hanging in clusters from the eaves and cornices; some clusters were at least 2 feet in length, and at intervals benumbed individuals dropped from the outside of the clusters. Many hundreds of the poor birds fell victims to the ruthless ignorance of the children." On September 1, 1876, Mr. J. H. Gurney, jun., wrote: "The boisterous weather of yesterday, accompanied by much cold and rain, appears to have had an effect on the Swifts at Dover. Many have flown into houses and been captured by hand this day (September 1), as I am informed by Mr. Gray, the taxidermist, to whom some were brought, and at whose house I saw two. I do not 
think this is unusual with swifts. It is well known they are very susceptible of cold, more so than the Swallow, as is proved by their coming later and leaving carlier. Mr. Gray mentioned to me, as a remarkable instance of the feebleness to which they can occasionally be reduced, that once the walls of St. Mary's Church, in Dover, were covered with them, hanging in great clusters, seemingly incapable of exerting their power's of flight."

In Birds of Rainham, by Mr. IV. H. Power, he says: "The Swift was first seen this year (1865) on May 3, This bird is not common in the neighbourhood, there being no suitable breeding-place for them except the church-tower. Noticed them beginning to collect in flocks about July 13. I saw one this year as late as September 7."

Mr. G. F. Mathews says: "I noticed a Swift here (Sheerness) on September 15. Surely this is very late?" Mr. Boyd Alexander, in his notes in the Birds of Kent, says: "The Swifts also fly in batches, circling round high trees and towers alike. The shrill sound of the ceaseless screaming of their voices fitfully strikes one's ear as these weird-looking birds, with their curved wings, sharply quivering, cut through the air, and swinging round the trees with such fine tact and precision that they hardly as much as tickle or scrape the leaves' smooth surface." In the Orlestone district the Swift was first observed on May 14, 1902.

In the Zoologist, 1904, Mr. E. P. Butterfield, in his ornithological notes, mentions: "As I was leaving my brother's residence on Shooter's Hill, Plumstead, early one morning about the third reek in June, he pointed out to me a pair of Swifts, which were breeding in the nest of a House-Martin." 


\section{WHITE-BELLIED SWTF'T.}

C'ypselus melba (Limneus). S.N., i., p. 44.5 (17666). Alpine Sirift.

There are three records of the occurrence of this species in Kent.

The first White-bellied Swift was shot in the Isle of Thanet in June, 1820, by R. Holford, Esq.'s, bailiff. This bird, according to Professor Newton in Yarrell's British Birds, was seen by Mr. J. Gould in 1832, and it subsequently passed into the possession of Mr. R. B. Hale, who lent it for the illustration of the above work.

The second specimen (Notebook of a Naturalist, p. 226) flew into a room at Dover on August 20, 1830, and was secured; and Professor Newton says this statement was not published till 1845 .

Mr. J. H. Gurney (Zoologist, 1886, p. 5046), after giving a short notice of this species, says: "While writing on this bird, I may as well mention a specimen which has not been recorded, which was seen by the Rev. J. Pemberton Bartlett in Kent, in June, 1871."

\section{Family CAPRIMULGIDÆ. \\ Genus CAPRIMULGUS, Linnæus.}

\section{NIGHTJAR.}

Caprimulgus europeus, Linnæus. S.N., i., p. $340^{\circ}$ (1766).

Goatsucker, Boys, 1792; Night-Hawk, Fern-Owl.

In the more open woods in Kent the Night-Hawk, as it is usually called, makes its home, but is by no means 
plentiful, arriving in the county at the end of May and early part of June, in pairs. After taking up a position for breeding they can always be found, and in the evening they will circle round one, uttering loud and jarring notes of alarm, and keep on following, to draw you away until you are far from the eggs, which are very difficult to find.

The Rev. J. Pemberton Bartlett records the following:-

Notes on the Goatsuckier or Night-Hawti.-" In the month of July I had brought to me a pair of NightHawkis, as Goatsuckers are provincially temed in Kent. They were quite young, and had been found at the foot of a tree with an egg, which was also brought to me. It is generally supposed that the Goatsucker lays only two eggs; this, however, was an instance to the contrary. Being desirous of rearing them, I fed them with flies and other insects, which at first they appeared to thrive on, but after a little, from some cause I could never quite understand, they began to droop, and finding they were gradually sinking I killed and stuffed them. Wishing to obtain a specimen of the full-grown birds, I proceeded one evening to the wood from which the young ones had been taken, and after waiting a short time I observed a pair of Goatsuckers (probably the parent birds) hawking round an oak close to the spot described to ine as the place the young had been found in. I succeeded in shooting them both, and found they were male and female; they are now with the young ones in my cabinet.

"It is perhaps needless to remark, that this bird derives its name from the ancient and ignorant idea that it sucked goats, which is in the same degree probable 
as that hedge-hogs performed the same kind office for cows. Although not a rare bird, yet from its habit of flying only in the evening and at daybreak it is not very generally observed. There is something very peculiar in the appearance of the Goatsucker when sleeping in the day. I recollect once shooting at what appeared to be a rat crouching on the large arm of a high cherry tree, but which, upon its falling to the ground, proved to be a Goatsucker. It is a constant habit of these birds to perch lengthways, with their heads lowest, that is, inwards to the tree. They are not unfrequently found squatting on stone heaps, where they look not unlike a lump of old wood or bark covered with lichens. There is a peculiarity about the foot of the goatsucker, the midale claw being serrated, the exact use of which has not, I believe, been accurately determined. White thought it was to assist the bird in taking its prey, he having observed it take beetles with its claws and convey them to its mouth. Wilson, on the other hand, supposed this claw was used as a comb to keep in order the bristles which grow on either side of the upper mandible. While others imagine it to be used for the same purpose as the pectinated claw of the Night-Heron (Nycticorax europeus) namely, to free the bird from vermin in those parts which it is unable to reach with its bill. Is it improbable that it may be used for all these purposes?

"Goatsuckers arrive in this part of Kent about the second week in May, and generally take their departure by the beginning of September. Their common note is somewhat between hissing and buzzing, which has been said to be in imitation of the low notes of beetles. As I was returning home between 11 and 12 o'clock one brilliant moonlight night in August last, my attention was 
attracted to a bird which flew up before me from the road. I soon discovered it was a Goatsucker. It several times settled at no great distance, and I observed that it lay almost flat in the road. I at first supposed the cause of its settling to be that it might the more easily dissect some large beetle, but upon watching it I found it was evidently dusting itself, after the manner of domestic fowls. I an not aware if this trait in the character of this bird has been noted. So far from the Goatsucker deserving the bad character which was so long attached to it, I cannot but look upon it as a bird which renders more service to man than at first sight it appears to do, as it must not be forgotten that the larva of the majority of the insects on which it subsists are very destructive to the roots and buds of many plants and trees. I have found its eggs-nest it has none; these are generally placed in a rood or shaw, at the foot of a tree or bush, on a few dried leaves or grass, whicherer may happen to be on the spot" (Zoologist, 1841).

In the Zoologist, 1852, Mr. WV. H. Thomas wrote the subjoined particulars respecting the habits of the Fern Owl, or Goatsucker, in Kent:-

"Song of the Fern-Oul.--The first time that I heard the song of the Fern-Owl to perfection was one fine, war'm summer's night. In the afternoon of June 25, 1828, I had at ease walked away from the incessant noise and din of the great metropolis, to enjoy myself in scenes far more congenial to my mind. Avoiding as much as possible the dusty roads, I struck across the Lewisham Road at the parish boundary post, over the hilly fields, to Lady Well and Lewisham Church; again across the Tonbridge Road, up the long lane by Hither Green, then into the great road again near 
Southend; continuing on the road until I crossed some fields on the left hand, I arrived at a beautiful meadow, bounded on two sides by thick, tangled wood, in a rather wild part of the country, between Bromley and Chislehurst, Kent. The grass had been cut, and the hay made into large heaps or cocks, ready for carrying. By the time I had reached this place the sun had gone down in all its glorious splendour. Not caring about returning to town the same night, and there being no place nearer than Bromley where I could lodge, and besides, being unwilling to enter a public-house, I determined to pass the night in the field where I was. Night came on apace, and I had seen no human face since I entered the meadow; so I set to work and made two of the hay-cocks into one large heap, at a short distance from the wood-side: and then, mole-like, burrowed into the middle of the hay, just leaving my head outside for a little fresh air, and free for any observations I might have occasion to make, as well as to watch the course of the moon, which had risen in unclouded beauty. Here, then, was a soft, warm, and deliciously sweet-scented bed, made in quick time; and I had not rested long before I found it necessary to throw off a layer or two of my fragrant covering, for I began to get too hot. At length sleep overcame me, but how long I had remained in that state, when I awolie, I cannot say; I had a confused idea of elves, spirits, fairies, and such-lilie imaginary beings haunting me in my sleep.

"I had not long been again settled on my grassy couch, reflecting upon my wild fantastic dream, with all its attendant revelry, when my attention was drawn to the singular, wild, ringing strain of the Fern-Owl; it resembled at times the whirring, rapid rotation of a wheel, now 
swelling, now diminishing, the sounds intermixed with churring and croaking notes, some of the sounds having a ventriloquial effect: there was now and then a sharp, unearthly kind of shriek. Presently there were the same sounds issuing from other quarters of the wood, until the whole place was ringing with the wild nocturnal notes. As day-break advanced, I could see the Fern-Owls (there were at least from four to six birds) hawking for moths, chasing and pursuing each other, and sweeping along with surprising sudden turns and tumblings. As I sat motionless, with my head just above the surface of the hay-cock, I had a good view of their proceedings; the birds were continually snapping at the numerous small moths which were hovering over the heaps of hay. The birds are not very shy when pursuing their prey, for they would glide along close to me; amidst the gloom one could see them looming in certain positions, as a ship at sea is sometimes to be seen in the night-time. At times the Fern-Owls would suddenly appear close to ine as if by magic, and then shoot off, like meteors passing through the air.

"The spectral and owl-like appearance, the noiseless, wheeling flight of the birds as they darted by, would almost persuade one that he was on enchanted ground, spell-bound, whilst witnessing the grctesque gambols of this singular bird; there only needed Pucl, with his elfin crew, attendant fairies, \&c., in connection with the aerial flights of the Fern-Owl, to have made it, as it was to me, a tolerably complete Midsummer Night's Dream, especially as the ferer of my night-haunted imagination had not as yet vanished. As it was, I was delighted with this nocturnal and beautiful scene from Nature, and I wished at the time that some of our museum naturalists had been with me, to have shared the pleasure that I felt. 
"Daylight now rapidly advanced, and the Fern-Owls had vanished into their woody domain, and all was still. After a good wash at a little brawling rivulet, I felt myself refreshed, and my rustic toilet completed, I dashed into the thick tangled wood in search of further adventures.

"At the latter end of June, 1830, I started at 12 o"clock at night with a friend from Bermondsey, Surrey, for a walk to Bexley, over Dartford Heath, to Wilmington and Hawley, Kent. We arrived at the Bull Inn, on the top of Shooter's Hill, between 2 and 3 o'clock in the morning. Here the Fern-Owls were busy, hawking for food about an elm tree close to the inn, and we sat down on the bench outside the house for half an hour to refresh ourselves, and at the same time to admire the clever, quick movements of the birds. There were several of them, and they hept flying about the outskirts of the wood opposite the inn; but the elm tree seemed to be a favourite resort, there being no doubt plenty of moths and beetles about it. The place was all alive with FernOwls, and their continued singing, with occasional sharp squeaks, made the locality ring again, particularly about the keeper's house. The birds did not seem in the least alarmed or shy at our presence, but flew so close to us that I nearly knocked one down with my stick."

Captain Boyd Alexander, in his notes on birds in Kent (Zoologist, 1896), says: "The woods are now destitute of bird-voices, save at times for the fitful cooings of the Ring-Doves. The Nightjars, too, are silent. Their monotonous songs ceased as soon as the young were hatched. Nestlings of this species are frequently found here very late in the autumn. One was taken near Sissinghurst on August 10, and I have on record much 
later dates than this. While pairing the Nightjar is very noisy. As soon as twilight begins to fade into dusk the male bird glides noiselessly up to a leaf-ridden and rotten tree-limb and immediately utters his call-note, a loud metallic twyrrt. When this has attracted the attention of a female, who utters back a similar note, he commences, though many trees may separate them, his grinding churr, resembling the noise of an axe being sharpened on a grindstone. This peculiar song is begun loud-so loud that the dead bough seems to vibiate with the sound. Suddenly the notes become soft and hardly audible, just as if the bird was taking breath for a moment, and then these soft notes are run again into the loud ones. This churing song, always marlied at regular intervals by the soft bars, lasts at the most for two minutes. Then a short period of silence elapses before another grind talies place. And in this still silence one can almost picture to one's self the sharpener feeling his axe before putting the finishing touches to it on the grindstone. Besides this song and call, the Nightjar has an alarn-note. It is a strident tuyrrt, accompanied by a double clap of the wings. A branch, dry and sapless, the bark of which hangs peeled off in long shrumk-up tubes-a white dusty road or a lately felled tree, shorn of its bark and shooting out its naked arms into the blank night, are places they seek by choice. From such points of rantage their large, lustrous black eyes can the more readily detect the white moths that flutter aimlessly amongst the undergrowth, like pieces of delicately cut muslin falling from a dressmaker's table. 'The Red Underwing is also a favourite food. On a clear and calm night their chumings are loud and frequent. But when a night-wind is sifting through the trees, and grey-lag clonds darken the summel' 
night, the Nightjars seem discomforted; they sit close, hugging the rotten bough for very comfort, and the purring churr is seldom uttered. During the first week in September these birds will leave, not to reappear till the middle of next May.

On Nay 14, 1902, Mr. T. Hepburn found a Nightjar on the beach at Dungeness.

\section{Family PICIDÆ.}

\section{Genus PICUS, Linnæus.}

\section{GREAT BLACK WOODPECKER.}

Picus martius, Linnæus. S.N., i., p. 173 (1766).

On the authority of $M I r$. R. T. Filmer the present species is admitted in the fauna of Kent. It appears that he observed this bird in the first week in Jannary, 1905, on the top of a telegraph pole, in the railway cutting near Bourne Wood, Orlestone, Kent, and it is supposed that the same bird or its mate was seen by one of Mr. Balston's keepers-Stickles-independently of the above observer, who was unaware that Mr. Filmer had seen one; and it was not far from the same locality. The description of the bird given by Mr. Filmer, as being entirely black, about as big as a Jackdaw, with a red patch on the head, agrees exactly with this species. 


\section{Genus DENDROCOPUS, Koch.}

\section{GREAT SPOTTED WOODPECKER.}

Dendrocopus major (Linnæus). S.N., i., p. 176

$$
\text { (1766). }
$$

Great Spotted Woodpecker, Boys, 1792; MagpieGalley-birds, Lord Clifton.

The Great Spotted Woodpecker, although generally distributed throughout the county, is not an abundant species, always keeping to the larger and older woods. They are more often seen in the autumn and winter, and no doubt their numbers are increased from the north, but during the summer they diminish again, going north to the larger and older forests for the breeding season.

According to Lord Clifton, in his notes on the Birds at Cobham: "Two broods of the Great Spotted Woodpecker were reared there in the summer of 1868." The natives, he says, call them "Magpie-Galley-birds," galley-bird being their name for Woodpecker.

Mr. A. Skinner obtained an " adult male of this bird in the summer (1868), shot a mile from Faversham, and a female on November 2, of the same year, shot in Faversham churchyard." It is included among the birds of Bethersden, by Captain J. D. Cameron. There are specimens in the Maidstone Museum taken at Mereworth, March 13, 1892, and at Linton, July 2, 1897, by Mr. H. Kennard. It has been found at Erith, according to the Rev. C. H. Fielding. Mrr. W. Prentis says: "The Great Spotted Woodpeckers, when they do come to Rainham, which is very rarely, invariably come in the month of October." 
Mr. R. J. Balston, on June 27, 1902, watched a Great Spotted Woodpeclier in Haberdasher's WVood, feeding its young, from about 3.28 till 3.52 p.m. It fed them four times, the first three times in about thirteen to fourteen minutes.

On April 1, 1906, a Great Spotted Woodpecker was observed searching the trunks of trees, evidently for a suitable nesting place.

\section{LESSER SPOTTED WOODPECKER.}

\section{Dendrocopus minor (Linnæus). S.N., i., p. 176 (1766).}

The Lesser Spotted Woodpecker is decidedly a rare bird in Kent.

According to Morris it has occurred in Greenwich Park. Mr. A. Skinner obtained a female on January 13, 1869, in Faversham Churchyard. There are specimens in the Maidstone Museum, one a male from Chart Sutton, from Mrs. T. Balston, and a female obtained at Linton, January 11, 18s8, by Mr. H. Kennard, and an egg from Boughton, taken June 20, 1885, by Master Rolfe. It is included in the following districts: Bethersden, Captain J. D. Cameron; Cobham, Rev. C. H. Fielding. It has been found in Blean WVood near Boughton, Mr. R. J. Balston. Mr. Filmer says it is rare in the Orlestone district. Folliestone, H. Ullyett, and Stourmouth, G. Dowker.

There is a specimen in Mr. W. Oxenden's collection in the Canterbury Museum, which was obtained at St. Alban's Court, Kent, in 1822.

MIr. IV. Prentis says "it has been met with and 
obtained on several occasions in our lower orchards adjoining the marsh at Rainham."

\section{Genus GECINUS, Boie.}

\section{GREEN WWODPECKER.}

Gecimus viridis (Linnæus). S.N., i., p. 175 (1766). Green Woodpecker, Boys, 1792 ; Taffle, Galley-bird.

The Yaffle, so named in Kent from its loud langhing voice, is the most plentiful of the Woodpeckers in the county. There is scarcely a large wood or plantation without a pair or so of Green Woodpeckers; but this bird is not confined to the woods, it may be seen in the open pastures adjoining the plantations, feeding and hunting for insects on the ground.

Dr. A. G. Butler states that it " usually excavates a hole for itself in the partly decayed trunks of some soft. wooded tree; though in Kent I have chiefly noticed it entering holes in orchard trees." MIr. R. J. Balston found that it also bores into the hardest oaks, and he also noticed that it was common about Pluckley and Orlestone. Mr. E. Bartlett also found nests in solid oak trees in East Fient. There are specimens in the Naidstone Museum from Egerton, Ulcombe and Sandway, presented by $\mathrm{Mr}$. Boucher, and a female from Farleigh, by Mr. H. Kennard. It is included among the birds of Bethersden by Captain J. D. Cameron.

Captain Boyd Alexander (Zoologist, 1896) gives the following interesting notes on the "Green Woodpecker, that bird who mocks with its bright laughter the treacherous coming of spring, finds it difficult to rear 
a brood here, and consequently it is yearly decreasing as a breeding species. I attribute this fact to the great increase of the Starling. The big plagnes of the small oak-green caterpillar and other arboreal insects, experienced the last two seasons, have caused large numbers of Starlings to breed in the woods, and these birds are not slow to take advantage of the old homes of the Woodpeckers. Nore than this, they engage in pitched battles with them over their newly made holes. It is not unusual to find the Green Woodpecker resorting to the same nest-site of the previous year. In this instance the old hole is deepened. The drilling of a new one is accomplished generally by the tenth day, but the time varies according to the nature of the tree. The process of boring, as a rule, takes place during the small hours of the morning, when chances of discovery are thereby lessened, since the boring sound can be heard at a considerable distance. During the day the bole is left, and not returned to till the following morning. The Starling is quick to avail himself of this absence. The bottom of the newly drilled hole is soon lined with straw, and then there is every likelihood of a night ensuing at daybreak. The tactics of the Starling are to terrify his adversary. To do this he takes full advantage of his rapid and nimble flight, which the Woodpecker cannot match. At one moment he darts at his enemy, and is away again before he can retaliate, while the next moment he will be pouring out rolleys of angry abuse upon his foe. I have witnessed several of these fights, in which the Starling has invariably scored an easy victory." 


\section{Genus I I $\mathbf{N X}$.}

TVRYNECK.

Tïnx torquilla, Linnæus. S.N., i., p. 172 (1766).

Cuckoo's Mate, Snake-Bird.

The well-known "Snake-Bird" after its arrival becomes sparingly distributed over the county, and is generally found in the old woods and orchards, which are well stocked with old gnarled stumps and halfdecayed trees, in which the bird can find holes and large cavities for a nesting place. The following dates have been noted of the arrival of this bird in Kent: April 3, 1865; April 16, 1867; April 6, 1868; April 11, 1869; April 9, 1870; April 2, 1902; April 8 and 14, 1906.

The Rev. J. Pemberton Bartlett wrote the following note on the Wryneck in 1844: "A few years since I discovered in a hole in an old ash tree a single white egg, without any trace of nest. Not knowing at the time what egg it was, I supposed the nest had been taken, and that this was an egg laid afterwards, as it not infrequently happens with some birds, that when a nest has been torn and robbed of its eggs, if the full number had not previously been laid, an egg is deposited afterwards, but of course generally neglected. But this is not always the case, as I recollect an instance of a HedgeSparrow (Accentor modularis) sitting in a most persevering manner on an egg which had been laid on the foundation of its nest, the lining and eggs having been taken. Acting on this supposition, I took the egg, and on passing the tree the next day, had the curiosity to look into the hole, where, to my surprise, I found another egg; this I also took, and from that time the tree was 
daily visited either by myself or one of my brothers, and each day a white egg was carried away, until the number had arrived at twenty-two! After which, although we frequently visited the tree, not another egg was laid. Once or twice only was I able to catch a sight of the bird, which proved to be what is here provincially called a "Snake-Bird," and only linown amongst the lower orders by that name, and which I found to be the IVryneck (I Ïnx torquilla). I am not aware if the term "Snake-Bird" is peculiar to Fient. The reason of the Wryneck having this name assigned to it is, I should imagine, either from the hissing and really snalie-like noise made by the young before they leave the hollow tree in which they have been hatched, or from the rather. snake-like appearance of the old birds themselves, in some of their motions, or very probably from a combination of both these facts. The name certainly has more of truth in it than provincial names generally have. I have never heard of an instance of a Wryneck so perseveringly laying, when regularly robbed of its eggs; and indeed there are but few birds, I believe, which would have continued to lay more than double their usual number of eggs. I have heard of instances of a similar character in the common Wren, and in one or two of the Tit tribe; but this is the only one that ever came under my own immediate notice."

Mr. WV. H. Power, in his Birds Observed at Rainham, says: "The IVryneck was not quite so common this year (1865) as usual; in general it is to be heard all over the orchards, and I have several times, by means of a call, brought three at once into a tree within a yard of my head, where they would remain for some time, staring about in the most ludicrous manner. Their note is not 
unlike that of the Lesser Spotted Woodpecker, but is more prolonged and not nearly so shrill. The earliest record of their appearance that I have by me is April 3; their note last heard July 3 ; bird last seen August 27."

Dr. A. G. Butler states: "Towards the end of June, 1880, I noticed a Wryneck examining a decayed appletree in an orchard at Bobbing in Kient. One of the holes in this tree had been occupied the previous year by a Robin; the remains of whose nest still lay at the bottom of the cavity. Previously I had not taken the eggs of the Wryneck, and therefore I was interested in more senses than one. Watching the bird through my glasses I was convinced that it had decided to take possession of the Robin's old nest; but as I was returning to town in a day or two, I lnew I could not myself take the eggs, so I called the son of the man who rented the orchard, and promised him a shilling to send me the complete clutch. A little more than a week later I received five eggs, which were all that were deposited."

Unusual Nesting-Site for the Wryneck.- "In the last number of the Zoologist (p. 265) I recorded the fact of a Tree-Sparrow nesting in a mole-burrow in a brick-earth cutting in Kent. On July 9 I was examining the holes in the same cutting on the chance of finding a late nest, when I heard a sound not unlike that made by shaking a handful of silver coins, issuing from one of the holes; after half an hour's hard work I was able to insert my hand, when I discovered that the hole was occupied by five full-fledged young Wrynecks. There appeared to be no nest, or, if there was, it was so completely concealed under the mass of malodorous guano that I did not discover it. I have never met with any recorded instance of the Wryneck breeding in a hole in the ground, and it 
may therefore be of interest to publish the facts."-A. G. Butler (Zoologist, 1887, p. 299).

Wonderful Egg-producing Powers of the Wrynech."A friend of mine discovered the haunt of a pair of these birds, I ̈̈nx torquilla, in a plantation at Farnborough, in Kent; he had noticed them going and coming from an old decayed plum-stub about 5 feet 6 inches or so in height. Not being able to see far down the hollow limb, he broke a strip away, which fortunately snapped off at the very bottom of the hole, a distance of fully 2 feet. Where first found, on May 13, 1897, there were seven eggs lying on the bare wood, which he took, afterwards replacing the strip in position. 'T'wo more eggs were laid by the 25th inst., and were left in statu quo, but had disappeared somehow the next morning. I'he bird deposited another on the 26th inst., to which were added two eggs of the House-Sparrow, to make up for those that were missing; all the three, however, lay broken at the foot of the tree on the following morning. She then seemed to settle down to regular business and continued laying every day without intermission, each egg being removed as soon as laid, the total number up to July 17 reaching sixty-two, less the three that were broken or missing, leaving fifty-nine eggs in my possession from the one bird, which I fancy must establish a record. Concurrently with this another bird was laying in an adjacent plantation, but in a more erratic fashion, the eggs in this case being removed in batches of four or five. On two occasions she stopped laying for a day or two, and then continued depositing again; total number of eggs forty-three." - H. Alderson, Farnborough, Kent. (Zoologist, 1897, p. 511). 


\section{Family ALCEDINIDÆ.}

Genus ALCED0, Linnæus.

KINGFISHER.

\section{Alcedo ispida, Linnæus. S.N., i., p. 179 (1766).}

The scarcity of the Kingfisher in Kent is attributable to the large number that have been killed for their beautiful plumage, but now there is every prospect of their increase in the country. The Kingfisher hunts out all the streams and lakes that are well stocked with small fish, upon which it feeds, always selecting an overhanging tree, from which it drops like a stone upon its prey, and returning generally to the same branch or one near by ; there it may be seen to rap the lively little fish against the branch until dead, before swallowing it.

Nr. J. W. Hulke, writing on the occurrence of the Kingfisher at Deal, says: "February 6, 1849: I saw a Kingfisher in the marshes to-day, a very rare occurrence in this neighbourhood. May not this be owing to the great number of water-rats which swarm all the streams, destroying their eggs, as I believe they do those of the Moorhen and Water-Rail?"

In the Zoologist, 1851, Mr. W. W. Reeves, writing to the editor, says: "I have enclosed you part of the Kingfisher's nest which I found yesterday (Nay 8, 1851) near this place (Tunbridge Wells). It contained seven eggs, but they were so nearly hatched that it was impossible to extract the young ones. It weighed $2 \frac{1}{2}$ ounces and was full of maggots." ("This nest consists entirely of small fish-hones, a very usual circumstance, and principally those of Roach and Dace."-E. Newman.) In Mrr. W. H. Power's Birds Observed at Rainham, 
1865, he says: "I am afraid that Kingfishers are not so common as they were even a few years ago. This autumn (the season during which they are usually most common about Rainham) I scarcely saw any, while in 1863, at the same time of year, I met with several daily; and even allowing that I saw the same bird more than once in the course of the day, I am afraid it goes some way to prove that they are gradually becoming more rare. They used occasionally to breed in the banks of a deep pit, at a little distance from the marshes; but I believe the spot has been deserted by them for some years."

The various localities in which the Kingfisher has been obtained are: Loose Bridge, Farleigh and Tovil, on the Medway, 1874, H. Lamb; a female obtained at Malling, September, 1878, Mr. R. J. Balston, and another December 30, 1887, on the Medway; a female in the Maidstone Museum, from Boughton Monchelsea, November 15, 1883, from Mr. F. Smith; one female, Medway, December 1, 1870, in the Maidstone Museum. Mr. H. Payne; Bethersden, Captain J. D. Cameron; female, Romney Marsh, September 3, Dr. R. B. Sharpe, in the British Museum.

The Kingfisher, Mr. G. Dowker (1889) says, "is generally distributed along the banks of the Stour, and too frequently killed for its beauty. In winter it will come near dwellings, though generally a shy bird." Mr. R. T. Filmer states that it is occasionally seen on the Royal Military Canal and in the marshes. It has been seen to visit some of the large ponds in the Orlestone district, and adjoining parishes.

In his Birds of North Fient, Mr. T. Hepburn remarks : "It strikes one rather by surprise to see a Kingfisher 
flash past on these salt marshes. Curiously enough, two of my notes of this bird fall within a day of each other in consecutive years-November 16, 1902, and November 15, 1903; but I have also several notes of them about the land-marshes at the time of the year-November and December."

Mr. R. J. Balston observed them at Capel, Orlestone, and at a pond at Jenky Farm, 1901-5-6.

\section{Family CORACIIDÆ.}

\section{Genus CORACIAS, Linnæus.}

ROLLER.

Coracias garrula, Linnæus. S.N., i., p. 159 (1766).

Professor Newton, in the last edition of Yarrell's British Birds, mentions four examples that have been obtained in Kent, but unfortunately without data, and whether the subjoined particulars refer to the four specimens must remain an open question.

The first is a specimen labelled Fent in the Exeter Museum, bequeathed by the late Rev. Bower-Scott, but without any further notes.

The second, according to the Rev. J. Pemberton Bartlett, 1844, "is a specimen in the collection of Dr. F. Plomley, who "informed him that it was occasionally to be met with in Romney Marsh.' He also states that a good specimen was shot a year or two ago at Wootton."

The last one was obtained by Mr. W. Prentis at Rainham, Kent, who states, in the Zoologist, 1889: "The recent occurrence of the Roller, one of our rarest 
Continental visitors, is, I think, worth reporting. When first seen, on November 8, 1888, it was sitting upon the end of a mangold-wurzel clump, where my labourers were at work. As it appeared to be very weak, they gave chase over the hedge, and finally captured the bird alive on our Rainham marsh. It was very thin in condition, dying soon after being caught, its death being probably hastened by the effects of a very cold day."

\section{Family MEROPIDÆ. \\ Genus MEROPS, Linnæus.}

BEE-EATER.

Merops apiaster, Linnæus. S.N., i., p. 182 (1766).

The only records of the occurrence of the Bee-Eater in Kent are given by the Rev. J. Pemberton in his Ornithology of Kent, 1844, as follows: "A specimen of this rare bird was shot at Kingsgate, in the Isle of Thanet, in Nay, 1827. (This specimen is figured in Yarrell's British Birds.) There is also one in Dr. F. Plomley's collection, which was shot in the parish of Lydd, in Kent." The third bird is in the Exeter Museum, labelled Kent, bequeathed by the late Rev. Bower-Scott.

\section{Family UPUPIDÆ.}

Genus UPUPA, Linnæus.

HOOPOE.

Upupa epops, Linnæus. S.N., i., p. 183 (1766).

From the long list of records of the occurrences, the Hoopoe is a frequent visitor to Kent, and would become 17 
more abundant if not persecuted. From all that can be gathered respecting its sojourn there is little doubt that the bird has bred in the comnty.

Latham, in his Synopsis, ii., p. 688 (1782), gives Kent as a locality for the Hoopoe, and in the Supplement, p. 123 , he states: "The last year, 1786 , a young bird was sent to me, on May 10, full-fledged, shot near Southfleet, in Kent, by Mr. Godden; but the old birds had not been observed."

Boys in his Birds of Sandwich, 1792, adds the Hoopoe to the birds of that district. In the Topography of Maidstone, 1839, it is mentioned that "one of these curious birds was shot at Style Bridge, near Marden." The Rev. J. Pemberton Bartlett, in 1814, says: " Tre generally receive an amnual visit from one or more specimens of this very pretty bird." Dr. F. Plomley has three specimens, killed in Rommey Marsh. Two more were killed at Fredville, a year or two since, and one at Ileden, in the parish of Kingston." There are specimens in the collection of the late Mr. IV. Oxenden Hammond, from Nonington, in Kent, and from Lydd, now in the Canterbury Museum. One labelled Kent in the Exeter Iuseum, the bequest of the Rev. Bower-Scott.

In the Zoologist, 1844, Mr. E. H. M. Sladen writes: "The Hoopoe can scarcely be called an uncommon bird now in some parts of England. As Mr. Bartlett says, it generally visits the east of Kent annually. Several have been seen at Ripple Court, near Deal, and one was shot, and is now possessed by the family there."

Mr. W. H. Cordeanx, writing to the Zoologist in 1851, says: "A fine specimen of this beantiful bird was shot a fortnight since, in Lower Walmer. It weighs about 12 ounces and is nearly 12 inches in length. This, with the 
seven recorded in the Zoologist for June, would seem to evince that this 'fair feathered one' is becoming yearly more partial to our clime; but how annoying it is to the real lover of Nature, to learn that no sooner does that occasional visitant take up its abode with us, than it is shot by the hand of someone, whose heart wars with the outward world of beauty, and whose mind is too bloody to appreciate the perfect form of the Hoopoe, or any other created thing. Is it not a disgrace to our naturalists, to our magazine of Natural History, to every enlightened man, this daily butchery of rare and beauteous birds?"

In the Zoologist, 1852, Mr. J. IV. Hulke contributed the following article on the habits of the Hoopoe:-

"I send you a few remarks on the habits of the Hoopoe, several of which birds have occurred near Deal during the last month. I saw one on the 6th, and two on the 24th (April); one of these I shot and the other was shot by a friend. On the 26th, two were seen on some rising land three miles from here, and another occurred at Canterbury. The three I saw were on the sand-hills, a dry, sandy, hillocky slip of land, flanked by the sea on one side, on the other side by marshes extending from Sandown Castle to the mouth of the River Stour, and covered chiefly with tufts of long coarse grass. For many weeks the wind had been east and north-east; and coming throngh the sand-hills on April 6, I saw a Hoopoe, which, crossing the hills from the sea, passed over a hedge into a bean-field. Its actions were quick; it ran very swiftly for short distances, then pecked the ground, raised its crest and ran again. It flew for about 70 yards close to the ground, with a very buoyant flight, and rather slowly, but when flushed its flight was rather lofty 
and well sustained. On the 23rd I saw another about a quarter of a mile from the same spot where I saw the first. The white rump is very conspicuous when the bird is on the wing. On the 24th, very early in the morning, I shot this bird; it was only winged, and when I picked it up it bristled up like a game-cock, but this was all show, no actual resistance. In a few minutes I found another, which I did not shoot, but it was obtained by a friend a few hours afterwards. Both birds were females. None of the ova were larger than mustard seed. The gizzards contained several caterpillars and small beetles. Within a few years five other's have occurred here, besides several reports not so worthy of implicit reliance."

Mr. H. Whitely, in writing to the Zoologist, 1861, says: "On May 14, 1861, I had a very fine Hoopoe brought to me. It was shot on the morning of the 12th, on Plumstead Common, Kent. Upon dissection it proved to be a female; some of the eggs were as large as No. 5 shot, and the stomach was full of the remains of beetles. The bird was very fat, and in splendid plumage."

In the Zoologist, 1862, Mr. J. Harding recorded “a fine female Hoopoe, shot near Deal in August, 1862."

Mr. J. Hunter records: "A Hoopoe was shot on April 21,1870 , at Lees Court, near Faversham; it was in fine plumage, but rather a small specimen." Another Hoopoe is mentioned by Mr. W. J. O. Hall, who says: "When out shooting on September 25, 1876, I shot a very fine Hoopoe near Faversham." Lord Clifton records one from "Longfield, near Gravesend, on or about April 14, 1880." One is also mentioned in the Field of April 9, 1881, from Gravesend. In the Stourmoutl district, $\mathrm{Mr}$. G. Dowlier states that between 1885-87 the "Hoopoe 
has frequently been met with in my neighbourhood, often found in the marshes and uplands bordering the Stour, and generally in the autumn, and young birds are generally those recorded, and a specimen of the Hoopoe was shot lately near Dover, by Mr. Crundel, while out Part ridge shooting in November, 1889."

In September, 1892, a specimen was obtained in the Manor House garden on the Tonbridge Road, Maidstone, and it is supposed that it has bred near that place on two occasions or more. The Rev. C. H. Fielding states that the "Hoopoe was found at Ryarsh, in Kent, where it built for some years." In his Birds of Rainham Mr. WV. Prentis says: "The Hoopoe has upon two occasions at least been met with, once in the spring of the year and the other in the autumn, both times near trees on the border of the marsh. A third Hoopoe is said to have been seen this spring (1894)." There is a specimen in the Maidstone Museum labelled Kent, presented by Mr. G. Simmons; and it is also recorded from Aylesford, near Maidstone, April, 1894. A specimen was procured by Mr. G. Bensted at Ulcombe, in Kent, on September 1, 1898. Mr. A. Randall Davis (Hythe, Kent) states in the Field: "On April 6, 1906, a Hoopoe appeared on our lawn, and was our welcome guest on that and the following days, but on the eighth has not been seen. He spent the greater part of his time on a grass bank, where he seemed to find food to his liking. He used his bill like a pickaxe, and threw up his head to swallow the food. $\mathrm{He}$ was not very shy, and one could sometimes get within 4 or 5 yards of him. His arrival caused a great commotion amongst the other birds; the Thrushes and Blackbirds scolded him, and the Jackdaws chased him round the trunks of the elm trees, but they were all 
apparently more curious than angry. By the afternoon all had settled down quietly together. As the visits of this bird are now becoming rare, you may think this worth recording." It has also been mentioned by the late Mr. C. Gordon from Dover, and the Rev. WV. B. Delmar from Elmstone.

\section{Family CUCULIDÆ. \\ Genus CUCULUS, Linnæus. \\ CUCKOO.}

Cuculus canorus, Linnæus. S.N., i., p. 168

(1766).

Gowk.

The well-known Cuckoo, which every lover of birds listens for in the early spring, arrives at the beginning of April if the season is open and moderately warm, and may be seen or heard in all the woodlands and plantations throughout the county. The dates of its arrival vary considerably, which no doubt is to be attributed to the atmospheric changes, and the direction of the wind at the end of March and the early part of the month of April. In the subjoined particulars the data will be given in chronological order for easy reference.

Writing from Chart's Edge, near Westerham, in 1846 , Mr. J. F. Streatfield says: "These birds have been very numerous here throughout the summer; their eggs were found in several nests. In one nest (a Tit-Lark's) I found one half-fledged, which I took, to bring up by hand. It was very spiteful, spreading its wings and flying at my finger when offered food. During a month it was 
fed on hard eggs, butterflies, grasshoppers, \&c. It now fed itself, and never seemed to have enough food; one day it ate sixty-five butterflies (principally Meadow Browns) and a whole hen's egg. It lived till winter came on, when it died, without any apparent cause. I obtained one of the eggs in a Titlark's nest, and in another a young Cuckoo, which quite filled the small nest and had turned out the egg and young one of the Titlark."

Mr. H. W. Hadfield, writing to the Zoologist, in 1857, says : "Tonbridge, March 26, 1857: Observed a Cuckoo this afternoon flying low, so that in threading its way through the hop-poles it passed so close to me that I could plainly distinguish the varied and chequered plumage of the back." In this instance it is curious that the bird in the variegated plumage of the young bird should have made its appearance in Kent at such an early date. A strange instance of the "abundance of young Cuckoos" at Deal is recorded by Mr. H. J. Harding, September 20, 1862: "A great number of young Cuckoos are now being caught by the hand in and about gardens in this neighbourhood (Deal). Some fly into houses and sheds, and they are so abundant as to be noticed by the residents. They are extremely tame, and those which have passed through my hands are fat and in good condition. I believe them all to be young birds not yet able to take their flight."

Mr. A. W. Crichton, writing on the Deposition of Eggs b!y the Cuckoo, in 1863, says: "An anecdote was lately furnished me in corroboration of the above, while on a recent visit to Dover, by $\mathrm{Mr}$. C. Gordon, the able and enterprising attendant at the Museum there. He clearly remembers that a friend of his, thirty years ago, when walking in the park at Waldershare, the seat of the Earl 
of Guildford, observed a Cuckoo sitting on the ground in a ride under the lime trees along the edge of the wood. He knocked it over with a stick, and on squeezing it by the throat to expedite its dying struggles, the soft and fluid yolk of an egg, flowing freely forth from the base of the mandibles, caused him to exclaim, "TWhy he's got an egg in his mouth.' I have no donbt that similar instances of this habit of the Cuckoo have given rise to the prevailing notion that it sucks the eggs of other birds."

In his Birds of Rainham, 1865, Mr. WV. H. Power says the Cuckoo was "first heard on April 22. This species, like the Wryneck, was not quite so abundant this year' (1865) as last; indeed, their numbers vary greatly in different years, and in this district appears to me to bear a distinct relation to the presence or absence of a caterpillar that feeds upon the gooseberry leaves. In some seasons these caterpillars infest the bushes in myriads, and at such times the Cuckoos abound in the plantations, where I have often flushed from six to a dozen within a distance of 100 yards. In the early part of the summer of 1862 I more than once heard the Cuckoo singing at midnight; there was one in particular that generally commenced his song at 11 p.m., and continued it almost withont intermission till nearly one o'clock iu the morning. About the beginning of July the Cuckoos collect in the plantations near the river (Medway), and often take long flights out over the marshes, on which they sometimes settle to feed upon a species of caterpillar at this time to be found on the marsh plants. Towards the latter end of the month the old birds begin to retire on their migration, and are in their turn replaced by the birds of the year; these may be found till about the 
middle of August, but as a rule all depart before September. This year (1865), however, my brother shot one on the 11th of that month, the only instance, to my knowledge, of so late a stay."

During Dr. A. G. Butler's bird's-nesting in Kent in 1875, he found some Cuckoo's eggs which he describes as a "small reddish form, taken at Murston, May 29, 1875, from a Sedge-Warbler's nest. A larger greyish form was taken at Tonge Mill, Tonge, June 5, 1875, from a Reed-Warbler's nest."

In the Zoologist, 1878, Mr. A. Beale, of Chiddingstone, Kent, states: "About two years ago I found two Cuckoo's eggs in a Hedge-Sparrow's nest, both apparently laid by one bird, as neither was similar to any other Cuclioo's egg I have ever taken, but more resembled the Pied Wagtail's egg in colour. I mention this, as in the Introduction to Montagu's Dictionary of British Birds it is stated that 'where two eggs have been found in one nest, they certainly were laid by different birds.' I think the above affords strong proof that one Cuckoo does sometimes lay two eggs in the same nest."

Cuckoo's Eggs._- "On June 5 of last year (1884) I found in a nest two eggs of the Common Whitethroat and a Cuckoo's. The Cuckoo's egg was unusually handsome, somewhat resembling a finely marked egg of the Greenfinch, but having a rich creamy ground-colour. Within a few minutes I found another, about a hundred yards away, also in a Whitethroat's nest, and of a precisely similar description: there were four Whitethroat's eggs slightly incubated. On June 17, another Cuckoo's egg was found in a Whitethroat's nest, precisely similar to the above two. The position of this nest was about equidistant from the others and some 
120 yards away, and contained three Whitethroat's eggs. I have no doubt but that these three Cuckoo's eggs had been laid by one bird. If this be so, it strengthens the idea that each female Cuckoo probably lays its eggs only in the nests made by one species of bird. It seems probable, too, that a Cuckoo reared in, say, a Whitethroat's nest would by-and-bye lay its eggs in Whitethroat's nests, and that Whitethroat's nests would be selected by a sort of hereditary instinct. Dr. Baldwin, if I remember correctly, thought that the Cuclioo when about to lay was influenced by the colour of the eggs in the nest before it, and that in consequence its eggs assimilated in colour to those already laid by the owner of the nest. If there be anything in such colour assimilation, would not the fact $I$ have above recorded suggest that it may in part be due to gradual and hereditary influence?"-A. B. Farn, Dartford (Zoologist, 1885, p. 146).

Mr. G. Dowker, in his Birds of East Kent, says: "The Cuckoo is rel'y numerous in my neighbourhood (Stourmouth). It frequently makes use of the Hedge-Sparrow to rear its young. I have met with it also in the Spotted Flycatcher"s, Reed-Warbler's and Pied Wagtail's nests. I have often wondered if they return to their old haunts, like some other migratory birds, and I fancy they do. I have found them yearly in the same coppice soon after their arrival. They are incessant in their song by night as well as by day. It certainly carries its egg in the beak, when depositing it in other birds' nests."

In the Zoologist, 1895, Mr. Leonard S. Loat, of Southborough, Tunbridge Wells, writes: "On May 28 I found a Great Whitethroat's nest containing two eggs and one of a Cuclioo's. I took the Cuckoo's egg. Going again on the 31st, I found the Whitethroat had laid one 
more egg, and had then commenced to sit. This is rather unusual, as the normal number of eggs is generally five. The nest was situated in a hedge at the top of a high bank, bordering a road which was little frequented."

In Mr. R. J. Balston's notes he says that the flight of the Cuckoo is at times very heavy and apparently laborious, and that small birds will attack a Cuclioo in a tree, and drive it away, and that an immature bird was shot in September, at Chart Sutton, by him.

The Cuckoo was heard at 4.30 a.m. on April 12, 1902.

In the report on the immigration of summer residents in the spring of 1905 (Bulletin of the B.O.C.), the dates of the arrival of the Cuckoo are April 14 to 16, 1905, and May 7 they appear to have increased. The long severe weather of the spring of 1906 delayed the arrival of all the summer visitants, and the Cuckoo was first heard in the Orlestone district on April 17, and an egg was found in a Robin's nest at Bilsington on May 18. A young one was found in a hedge nearly opposite the railway signal-box and crossing at Upper Ruckinge, on July 6, 1906; it was reared in a Hedge-Sparrow's nest, and was fully fledged when discovered.

In the Fauna of the "Cedars," Lee, Rent, Mr. J. F. Green says: "The Cuckoo still remains faithful, though every spring we hear less of its welcome note, owing, no doubt, to so many properties around being amassed for building purposes. For years I had been trying to get a clutch of Hedge-Sparrow's eggs containing a Cuckoo's blue egg, and last year I succeeded. It is curious why a Cuckoo's egg in a Redstart's nest is nearly always blue, and yet hardly blue in a Hedge-Sparrow's, although Redstart's and Hedge-Sparrow's eggs are almost identical." 


\section{Family STRIGIDÆ.}

Genus STRIX, Linnæus.

\section{BARN-OWL.}

Strix flammea, Limnæus. S.N., i., p. 133 (1766).

White Owl, Boys, 1792; Screech-Owl.

The Barn-Owl is one of the best known of all the species in Kent on account of it frequenting the church towers, old barns and houses, in which it builds its nest and rears its young.

Although this owl is one of the most useful birds to the homestead and the farmer, they are ruthlessly destroyed.

The Rev. J. Pemberton Bartlett, writing in 1884, says: "I am always grieved to see this beautiful and most useful bird nailed, with extended wings, to barns and other depositories of gamekeepers' trophies. It is truly the farmer's friend, and at the same time I think not the game-preserver's enemy; at all events, to so slight an extent is it so that the good it does abundantly counterbalances its slight poaching propensities." This is-

"The owl, that watching in the barn, Sees the mouse creeping in the corn, Sits still and shuts his round blue eyes As if he slept-until he spies, The little beast within his stretchThen starts and seizes on the wretch."

Morris, in his British Birds, 1851, says: "The very last specimen but one that I have seen was a young bird perched on the exact centre of the reredos in Charing Church, Kent."

Barn Owl Preying upon Fish._."For several nights 
past I have observed a Barn-Owl about the harbour, but this evening, during a dead calm, and while the moon was shining very brightly, the bird appeared skimming rapidly within a short distance of the water. Suddenly it dropped towards the surface, and then instantly rising continued its flight towards the Isle of Sheppey. Some minutes afterwards it reappeared, repeated the same act, and again and again went through almost precisely similiar manceuvres, until I had witnessed the occurrence perhaps eight or ten times. It is remarkable that the bird was never seen returuing from the Isle of Sheppey; it invariably came from the direction of the opposite shore, so that the moon cast a shadow behind instead of before, and thus the fish could receive no notice of the approach of the enemy until it was close upon them. I was at too great a distance to see whether the bird's feet actually touched the water, but there can be little doubt not only that they did so, but that a fish was occasionally captured, for sometimes the bird after stopping rose burriedly, and describing a wide circle in its flight, returned near the same spot, and then made an apparently more successful pounce. Once it flew across without making any stop, but in this instance it returned sooner than usual. Several men belonging to the ship also witnessed the above, and one of them, a native of Kent, told me that when he was a boy he used very often to find fish-bones in a Barn-Owl's nest, but although his assertion may be open to doubt, the account given by various authors have long since established the fact that owls do occasionally prey upon fish. I myself have found the remains of fish in the stomach of the Tawny Owl."-H. L. Saxby, Sheerness, October 9, 1862 (Zoologist, 1862, p. 8281).

Barn-Owl and Rat.- "The following instance of 
instinct at fault, which has not been recorded, was communicated to me some time ago. In the autumn of 1865 a fine owl was brought to be stuffed. It belonged to a Mr. Wallis, farmer, of Leigh, near Tonbridge, Kent. The farmer's wife told me she had picked up the bird dead on the barn floor, and that beside it, also dead, was a very large rat. There is little doubt but that an encounter had taken place between them, the injuries received by each being sufficient to cause death. The bird had evidently been severely bitten by the rat."-J. H. Gurney, jun. (Zoologist, 1876, p. 4871).

Mr. G. Dowker, in his Birds of East Tient, 1889, says: "In confinement owls are most interesting birds, and they are constantly advertised as domestic pets. So this may have something to do with their being found in diminished numbers. I had once a Barn-Owl for some time in confinement, and it was quite as partial to sparrows as to mice. The specimen was a lady, and received clandestine visits from one of the male sex, until one night the gentleman managed to undo the door of the cage and let his lady-love free. I gave him credit for great intelligence and was rather glad he had so gallantly rescued the captive."

Mr. J. F. Green, in his Fauna of the "Cedars," Lee, Kent, remarks that the Barn-Owls love to sit at night, in a friendly way, by the TVest Lodge Pigeons, looking, no doubt, for mice."

This year (1907) Mr. R. J. Balston completed the restoration of Bilsington Priory. A pair of Barn-Owls, which had nested in the old building for some years, came back to a turret where a place was left on purpose for them. On May 28 the first egg was found, Nay 29 the second, June 1 the third, June 4 the fourth, June 12 the 
fifth. On June 21 the owl was sitting. The nest was not regularly visited for fear of disturbing the bird, but the first egg was not there on May 27. July 2, one young bird and five egors in the nest; July 25 three young birds.

\section{Family ASIONIDE.}

Genus ÁSI0, Brisson.

\section{LONG-EARED OTVL.}

Asio otus (Linnæus). S.N., i., p. 132 (1766). Eared Owl, Boys, 1792.

This species is not plentiful in many parts of Kent, but in the more cpen woodlands it is frequently met with, singly or in pairs. It is only a winter visitor to the county, and therefore only observed during the Partridge and Pheasant shooting season, when driven from its hiding places.

It was obtained by Mr. R. J. Balston, who shot one of these birds in the winter of 1871, when ferreting rabbits on the Boxley Hills. It flew out of a yew tree. As it had got some distance before seen it was only winged; when taken up it hissed and snapped its bill repeatedly. Another was obtained by a keeper on Boxley Hills on February 20, 1894. A specimen in the Maidstone Museum was procured by Mr. W. Hiclinot on December 22, 1882, and a male was shot by Colonel Franklyn, at Hollingbourne, on November 28, 1891. This bird was being mobbed by small birds in a fir tree; when shot it had a Linnet in its claws. The Rev. C. H. Fielding observed this species at Addington in the winter of 1892-3. Mr. R. J. Balston found it in the Orlestone district in 1902. 
On July 20, 1906, a Long-eared Owl was seen in the woods near Ruclinge; it flew up on to a dead bough, and looked about, and then flew on to another, ignoring the presence of the observer.

Mr. H. Elgar writes that "Mr. Boucher, of Maidstone. has a very light-coloured specimen of the Long-eared Owl, shot at Egerton in January, 1907."

\section{SHORT-EARED OWL.}

Asio brachyotus (Forster). Phit. Trans., lxii., p. $343(1772)$.

This owl is certainly an uncommon species in Kent, being an autumn and winter visitor.

The Rev. J. Pemberton Bartlett, writing in 1844, states that it was "common in Romney Marsh, and occasionally met with throughout the county." The marsh has greatly changed since then, and bird-life with it. There is a male specimen in the Maidstone Museum which was obtained in Romney Marsh in Jannary, 1881, by M. H. Kennard, and a female procured near Maidstone on March 5, 1892, by Mr. Turner. One of these birds was shot at Boxley by Mr. R. Balston when Pheasant shooting with Major Best in the winter of 1869-70. According to the Rev. C. H. Fielding, it has been found at Chalk and Ramsgate. Mr. WV. Prentis says: "When partridge shooting I have met with them in our turnip fields. On one occasion a pair nested and succeeded in hatching their young on an island marsh which had been lying idle throughout the winter and spring." 


\section{Genus SYRNIUM, Sarigny.}

\section{TAWNY OWL.}

Syrnium aluco (Linnæus). S.N., i., p. 132 (1766). Wood-Owl, Brown Owl and Ivy-Owl.

The Tawny $\mathrm{O} w \mathrm{w}$ is rather more numerous than either of the preceding species in Kent, and it breeds in the more secluded old woods and private plantations.

In June, 1874, one of these birds was caught at Boxley Abbey in a trap baited with part of a rabbit supposed to have been killed by a cat. It was a large bird and probably a female. There is a female in the Maidstone Museum obtained on September 2, 1892, by Colonel Franklyn, at Hollingbourne, and a male shot at Harrietsham on April 26, 1894, by Mr. H. Elgar.

It has been observed in the Orlestone and Ruckinge woodlands several times during the summers of 1902-6.

Mr. J. F. Green, in his Fauna of the "Cedars," Lee, Kent, says: "The owls are a great institution here, and I love to hear them. In June and July the young of the Brown Owls seem to call for food all night-a quick too-whit. The old birds give a very long-drawnout whistle, on a descending scale, followed by the same note in tremolo, like a child in distress. Our watchman sometimes sees them dive into the ivy after the roosting sparrows which swarm here."

Mr. R. J. Balston states that "a pair used to breed in an old tree in the Park at Clare House, Malling, 1878-81. They are also heard frequently in the summer at Springfield, in the outskirts of Maidstone. 


\section{Genus NYCTEA, Stephens. SNOWY OWL.}

Nyctea scandiaca (Linnæus). S.N., i., p. 132 (1766).

There are three records of the occurrence of this beautiful owl having been taken in Fent.

The first is a specimen in the Exeter Inseum, bequeathed by the Rev. Bower-Scott.

Morris states that one was lilled at Frinstead, in Kent, in 1814; and Mrr. G. Dowler, in his Birds of East Rent, says: "One specimen of the Snowy Owl was obtained from near Faversham."

\section{Genus SURNIĀ, Duméril. EUROPEAN HAWK-OTTL.}

Sumia ulula (Linnæus). S.N., i., p. 133 (1766).

The only Rentish specimen is that which is in the Maidstone Museum, presented by Mr. G. Simmons.

\section{Genus NYCTALA, C. L. Brehm. TENGMALM'S ONTL.}

Nyctala tengmalmi (J. F. Gmelin). S.N., i., p. 291 (1788).

The first Kentish specimen is that which is mentioned in Yarrell's British Birds (third edition, 1856): "In May, 1836, the late Mr. Leadbeater, of Brewer Street, received a specimen for preservation which had been shot 
in Kent." There is a specimen of this species in the Exeter Museum, labelled Kent, the bequest of the Rev. Bower-Scott. A Tengmalm's Owl was obtained at Dartford, in Kent, in November, 1881 (Field, November 18, 1881), and the Rev. C. H. Fielding records one killed in Kent in 1885, which may refer to the latter bird.

\section{Genus SCOPS, Savigny.}

\section{SCOPS OWL.}

Scops scops (Linnæus). S.N., i., p. 132 (1766).

According to Mr. J. E. Harting (Handbook, p. 336, 1901), a Scops Owl was obtained near Maidstone, and is now in the Dover Museum. In the Bulletin of the B.O.C. (vol. xii., p. 39, 1902) it is stated that MIr. Collingwood Ingram "sent for exhibition a specimen of a Scops Owl (Scops scops) which had been caught alive in a coachhouse at Broadstairs, in Narch, 1898, when a brisk south-east wind was blowing. The bird was liept alive for some time, but ultimately died and came into $\mathrm{Mr}$. Ingram's possession."

\section{AMERICAN SCREECH OVIL.}

Scops asio (Limnæus). S.N., i., p. 132 (1766). Mottled Owl.

In the Zoologist, 1870, Lord Clifton gave a long account of the "supposed occurrence of the Mottled Owl at Cobham in Kient, on April 11, 1870." This led to a great amount of correspondence from Captain $\mathrm{H}$. Hadfield and Mr. J. H. Gurney, jun., and must remain an open question. 


\section{Genus BUBO, Duméril.}

\section{EAGLE OWL.}

\section{Bubo bubo (Linnæus). S.N., i., p. 131 (1766).}

The first and only record of the occurrence of the Eagle Owl in Kent is that given by Dr. Latham in his General Synopsis, vol. i., part i., p. 1.16 (1781). He states: "It has been shot in Scotland and in Yorkshire, and, if a friend does not deceive me, has once been seen in Kent, perched upon a gate, near to a large wood, in the spring of $1770 . "$

\section{Genus ATHENE, Boie.}

\section{LITTLE OTVL.}

Athene passerina (Limnæus). S.N., i., p. 133

(1766).

The occurrences of the Little Owl in Rent are few, and the first recorded was by Mr. Whitmore Baker (Zoologist, 1856), who says: "A fine specimen of the Little Owl was lately taken in the neighbourhood of Maidstone, alive, and is so now in my possession; it being a rara avis, I thought it would be interesting to ornithologists" (May, 1856). In the collection of Mr. F. Bond is a specimen which was shot at Sevenoaks in Kent, in 1862. It is recorded from Cuxton in Kent by $\mathrm{Mr}$. Pye, but without data.

On May 25, 1906, a Little Owl was seen in a wood near Bilsington, Kent. Its discovery was caused by a lot of small birds, who created a hubbub and had mobbed it, but it was sitting in an oak tree quite at ease. This 
bird might have been one that was turned out in the district some time previously.

Mr. H. Elgar" writes: "I find I had made a note of seeing a Little Owl in the flesh shot at Cuxton in July, 1894. On March 2, 1907, we had a specimen of the Little Owl brought into the Maidstone Museum; it was shot at Cobtree, Boxley, whilst flying over some fowls, and was mistaken for a hawk. It showed no trace of having been kept in confinement and was in good condition; the crop was empty, but the gizzard contained a number of elytra belonging to small beetles."

\section{Family FALCONIDÆ.}

Genus CIRCUS, Lacépède.

\section{MARSH-HARRIER.}

\section{Circus eruginosus (Linnæus). S.N., i., p. 130 (1766).}

Boys, in his Birds of Sandwich, 1792, calls this species the "Moor Buzzard," which appears to be the oldest and most appropriate name for this bird. The Rev. J. Pemberton Bartlett, writing in 1844, states that it is "not uncommon in Romney Marsh." Those days are past, and it may now be considered a rare visitor to these localities; the large increase of the population and the cultivation of these marshes have driven the birds to more suitable places.

Mr. G. Dowker says that the Marsh-Harrier is very rare in East Kent. It has been obtained by Mr. IV. Oxenden Hammond at Nonington; by Mr. C. Gordon at Dover, and by Dr. F. Plomley in Rent. 
Mr. R. T. Filmer says that a specimen, the property of Sir J. Dewar, that fell to the gun of Mr. Stickles, of Orlestone, at one time gave the keeper's of that district a great deal of trouble.

A Marsh-Harrier, according to Mr. WV. Prentis, was shot in the woods at Rainham in June, 1867; it was of a deep chocolate colour, head included, and was just beginning to moult.

\section{HEN-HARRIER.}

Civcus cyaneus (Limmæus). S.N., i., p. 126 (1766).

The Hen-Harrier, like the preceding species, has become rare in Kent, although in former days no doubt it was plentiful and bred in the county. Boys includes it in his Birds of Sandwich, 1792, and the Rev. J. Pemberton Bartlett (1844) says it is " not uncommon in Romney Marsh." There is an immature male in the Maidstone Museum obtained on Boxley Hills on January 8, 1885, by Mr. A. F. Style. M[r. IV. Prentis, in his Birds of Rainham, says: "I once, when driving in the inonth of August, had the pleasure of seeing a pair, an old grey male and a brown female, circling round the centre of a field of barley off the main road."

\section{MONTAGU'S HARRIER.}

Circus cineraceus (Montagu). Ornith. Dict., 1, F. 2 (1802).

This species appear's to be a greater frequenter of Kent than the two former birds. There is no doubt that it used to breed freely in the large marshes of the county, 
but persecution has driven it away. In 1844, according to the Rev. J. Pemberton Bartlett, a pair were shot in May under the cliffs near Dover. In the Zoologist, 1853, Mr. James Green writes: "I have a fine old female of Montagu's Harrier that was shot in TVoolwich marshes on August 16 last."

In the Field, 1870, a note appeared, which was afterwards copied in the Zoologist, 1870, under the heading of Black Montagu's Harrier, as follows: "There is a very fine black male of this species, having a roseate gloss upon its upper parts, in the Canterbury Museum, shot near that city; and in the Dorer Museum I observed another, and was told by the Curator there that he had seen five or six like it in the course of his experience." -J. H. Gurney, jun. The former bird, and a rufousheaded young one, are still in the Canterbury Museum: they formed part of $\mathrm{Mr}$. W. Oxendon Hammond's collection.

Morris says that two of Montagu's Harriers "of a uniform dark colour," in the collection of Mr. Chaffey, of Dodington, in Kent, were shot by the Preventive inen at Dover. "One of them, at Mr. Chaffey's decease, according to Mr. J. H. Gurney, jun., became the property of the Rev. Bower-Scott, of Chudleigh, in Devon" ; this specimen is now in the Exeter Museum.

Writing to the Zoologist in 1871, from Cobham, in Fent, Lord Clifton states that "during September and October we had several Harriers about, which is also unusual. There was one pair of brown Harriers, very long and slender in shape, which I imagine to have been Montagu's Harrier; another, a male, in the conspicuous blue and white plumage, looked more like a HenHarrier, being rather a stouter bird, i.e., stouter than 
the smaller bird of the other pair, which I suppose was the male. I noticed that they perched occasionally on trees, but not often; more often on the ground or on the bushes stuck in the fields to prevent netting. They were generally to be seen hovering at no great height over the fields, or skimming low along the stubbles at about 6 inches from the ground."

The Rev. C. H. Fielding records Montagu's Harrier in the Higham district. A female was procured at Snoad Wrood, Staplehurst, Kent, in November, 1892, and recorded in Land and Water; and an adult male was obtained by Mr. Boucher, at Smarden, May, 1892. The late Mr. IV. Prentis, in his Birds of Rainham, adds the following particulars respecting the specimens in his collection: "The name Ash-coloured applies to the old male with black bar across its wings; six varieties have been obtained in my district, viz. : No. 1: Old wale with black bar across wings; June 8, 1866. No. 2: Old female dressed in shades of brown; May 17, 1869. No.3: Immature male, ash-coloured with some light brown feathers intermixed; May 15, 1869. No. 4: A darkcoloured variety, chocolate, almost black; Nay 18, 1867. No. 5: Dark chocolate mixed with brown; July 5, 1870. No. 6: Light brown on the back, on the breast white, slightly tinged with red ; Nay, 18s8."

Mr. M. A. Mathew states that he possesses examples of Montagu's Harrier from Kent.

Alleged Nesting 'of Montagu's Harrier in Tient."About the last week in June a young lady, a near neighbour, called to tell me that she had found a nest that she was anxious to identify, bringing with her a feather which had fallen from the bird as it left the nest. I at once recognised the feather as one of the outer tail- 
feathers of a Harrier, but of which particular species I did not feel sure at first. It certainly was not a MarshHarrier, and therefore was either the Hen-Harrier, Circus cyaneus, or Montagu's C.cineraceus. The locality, a marsh, did not accord with the usual breeding places of the Hen-Harrier, and on my showing a specimen of a female of each of these species, an objection was raised that the Hen-Harrier was too large. A further comparison of the tail-feathers of each left no doubt in my mind that the nest was one of $C$.cineraceus. The nest was in a dry part of the marsh, and placed in a thick clump of rush and Carex. Some of the material, which was also brought for my inspection, consisted of broken pieces of dry reed. The nest was described as very slight in construction. There was one pale bhish-white egg, and this was left in the hope that more would be laid. On a second visit the egg was gone, probably abstracted by a Rook, as no footmarks or trodden herbage was visible; nor was the bird seen again. I think there is no doubt whatever that this Harrier (Montagu's) had bred here."-TV. Oxenden Hammond, Wingham, Kent (Zoologist, 1897, p. 363).

\section{Genus BUTE0, Lacépède.} BUZZARD.

Buteo buteo (Limnæus). S.N., i., p. 127 (1766).

The Buzzard is a frequent visitor to Kent, and would become a permanent resident if allowed to exist, but its depredations are many, which precludes it from preservation.

A large number of specimens have been obtained at 
various times, and the subjoined particulars of its occurrences confirm that during the Franco-German War many were observed in the county.

In the Zoologist, 1868. Lord Clifton writes: "We have had several rare birds at Cobham this summer. During the beginning of August a Buzzard, of the common species, I think, nas several times observed. I saiv it inyself quite near me one afternoon, and it was observed near the same spot on the evening of that day, and on the next day. Each observer described it as a very big Hawk of owlish appearance and brown colour." Mr. A. Skinner says: "A specimen of the Common Buzzard was shot at Boughton, near Faversham, about December 28, 1868." In the Zoologist, 1871, Mr. C. Gordon, of Dover, writes: "Eight Common Buzzards have been captured during the present month (November) on the adjoining estates of Godmersham and Chilham Castle, near Canterbury. It is my opinion that a migration of these birds has taken place."

Lord Clifton, of Cobham, states: "In the month of November (1870) we were visited by a large flight of Buzzards, several of which are still frequenting the extensive woods about here. Two specimens were trapped on the adjoining estate, belonging to the Rev. J. Formby, whose lieeper supposed them to be Kites. Two fine specimens have also been caught in our woods in vermin traps. I have examined the birds myself, and believe them to be immature birds. They are undoubtedly the Common Buzzard, and measure 49 inches across the wings. The rest of the flight are constantly seen about the woods, and there nust be at least seven, if not nine, for on one beat five have constantly been observed together and separately, and on another beat 
two others are constantly seen which are undoubtedly different, one of them being of an extraordinary light colour. I attribute this unusual flight to the disturbance of the French woods by the war; for though in former years we have had six or seven at a time, we have never had so many as eleven before. The last of the extraordinary flight of Buzzards that visited this county during the war disappeared in April, 1871. The older keepers were already acquainted with the birds, having lived in the days when the "Puttock" and Kite were among the commonest Hawks, but now we have not a keeper that does not know the bird. They appeared to roost in company, for on one occasion six, and on another five, were seen together in the early morning. Among these Buzzards the lieepers observed a different bird, which was very light-coloured and had a greyish head, flying also in a different manner. I think this was probably a Honey-Buzzard." Triting again in 1872 , Lord Clifton says: "We have had one or two Buzzards here this winter, and they still remain (January 10), but not more than three at the most, nothing like the large flight of twelve or fifteen that visited us last year." According to Mr. D. T. Button, in writing from Gravesend in 1872, the larger Hawks were unusually common there during the last two years, 1871-72; he obtained two examples of the Buzzard.

Mr. IV. Prentis states that "according to the late Mr. C. Gordon, of Dover, twenty-five Buzzards were obtained in East Kent alone. I have heard of other's being obtained in West Kent, a pair was shot in my district." There is a specimen in the Maidstone Museum which was obtained at Boxley, Kent, by Mr. R. J. Balston. 
Mr. R. T. Filmer relates that a nest was taken from the Great Firs, Kent, about thirty year's ago. 'The bird has also been observed at Hollingbourne by Mr. R. D. de Uphaugh; and on April 11, 1906, a Buzzard was seen to come up from Romney Marsh and cross over in the direction of Bilsington.

Genus ARCHibUte0, C. L. Brehm.

ROUGH-LEGGED BUZZARD.

Archibuteo lagopus (Gmelin). S.N., i., p. 260
(1788).

A great many specimens of the Rough-legged Buzzard have been taken in Kent, and it appears to be a regular autumn and winter visitor, and some of these occurrences were caused, no donbt, by the Franco-German War.

There is a female of this species in the British Museum labelled Kent; it was presented by Dr. Latham, and in his Supplement to the Synopsis, p. 19 (17S7), he mentions that the Rev. - Wilgress, of Eltham, Kent, sent him a specimen; perhaps this is the same bird.

Montagu records one in Kent, picked up dead on the coast in the winter of 1792. The Rev. J. Pemberton Bartlett says: "This is but an occasional visitor. A specimen, which is now stuffed, was taken by the keeper of J. P. Plumtre, Esq., M.P., at Fredville, Nonington. There is also a specimen in Dr. F. Plomley's collection." Mr. A. Skinner records that a "Rough-legged Buzzard was taken by a keeper, in the summer of 1869, from a trap baited with Partridge near Faversham." Mr. D. T. Button, of Gravesend, writing February 21, 1872, says: "I have had several Rough-legged Buzzards sent me this winter; they were all females." 
When writing to the Zoologist in 1877 , Lord Clifton says: "It is somewhat remarkable that the Rough-legged Buzzard was unrecognised here until December 6, 1876, the common species occurring almost every year about November 1. On December $6 \mathrm{I}$ went to a well-known haunt of the Common Buzzard to see if any were about, and I at once perceived two Buzzards hovering over a mood. I noticed several peculiarities in their appearance. Their heads were conspicuously light in colour, and their long wings and hovering flight gave them a somewhat aquiline appearance. Waiting about the place, I very soon had a good view of one which was being chased by a Hooded Crow, and presently settled on a low tree. I had now no doubt what they were. The whitish head, white basal half of the tail, whitish underside of the wings, dark band across the belly, and yellowish edgings to the upper plumage, all convinced me that they were the rough-legged species. Seen on the wing, the mottled plumage of the back presented a sort of marbled appearance, with alternate light and shade. Seen sitting, the yellowish edgings predominated, maling the bird look like the light-colomred race of the Sea-Eagle which is found in Egypt. The light underside of the wings, excepting one dark spot, is a very rare mark of distinction from the common Buzzard. But above all, the flight is ummistakably different. It is almost the difference between a Kestrel and a Sparrow-Hawk, the wings of Archibuteo lagopus being long and slightly pointed, instead of straight and round ; this feature is very noticeable when the bird is flying away from you, the points of the wings being directed backwards. In the rapid beating of the wings, with alternate smooth glidings and shootings, the Rough-legged Buzzard resembles the 
Hawlis and Falcons rather than the Buzzards. Sometimes even he will streep along with curved wings almost like a Sea-Gull. The head looks less heary than in the common species. I am sorry to say that within fortyeight hours one of these fine birds was trapped at a Pigeon, which was supposed to have been killed by a Sparrow-Hawk. On December 18 and 19 I saw the other. Then disturbed, he perched on the very top of a tall ash, from which he watched the intruder intently. While looking at the two Rongh-legged Buzzards on December 6 they were joined by a third bird, uniformly brown in colour, and with shorter and rounder wings. This I have little doubt was a common Buzzard." The Rev. C. H. Fielding records three at Cobham in 1876, tro at St. Peter's, Isle of Thanet, and one at Waltham, near Canterbury. Captain J. D. Cameron records one that was shot at Woodchurch on December 21, 1879.

In the Maidstone Museum there is an immature male procured by Colonel Franklyn, November, 1891, and he also secured a female on November 10, 1891, both at Hollingbourne. Mr. G. Boucher obtained an immature male at Wrotham in November, 1891.

The following note is taken from the Standard, November 11, 1906: "A splendid specimen of the Ronghlegged Buzzard was shot by Mr. George May, of Thitegate Farm, Acrise, East Kent, whilst it was breakfasting off a dead lamb. This bird is now rare as a breeding species in England, although formerly it was not uncommon. The specimen just shot, which is to be stuffed, is 25 inches in length, and its ontspread wings measure nearly a yard and a half from tip to tip. Its fine plumage is brown above and greyish-white spotted with brown beneath; it has feathered legs, yellow toes, and 
black claws. A day or two before it was shot it was observed making a meal off a plump partridge."

\section{Genus AQUiLA, Brisson.}

$$
\text { GOLDEN EAGLE. }
$$

Aquila chryssä̈tus (Linnieus). S.N., i., p. 125 (1766).

There is a specimen of the Golden Eagle in the Exeter Inseum which was killed in Kent, and bequeathed to that institution by the Rev. Bower-Scott.

Genus HALIAËTUS, Sarigny.

WHITE-TAILED EAGLE.

Hatiaëtus albicilla (Linnæus). S.N., i., p. 123 (1766).

\section{Erne or Sea-Eagle.}

This species is a frequent winter visitor to Kent, and unfortunately it suffers for its visits. The occurrences of it in this county, as far as possible, are here recorded. The Rev. J. Pemberton Bartlett (18t4) says: "It is not infrequently seen in winter in Romney Marsh. 'l'here is a specimen in the collection of Dr. F. Plomley, which was shot here (Kingston)."

In Bagshaw's General History of Kent, vol. ii., p. 147, under St. Lawrence, near Ramsgate, at Cliff's End, it is stated: "On February 3, 1848, an Eagle of the fishing species was shot by Mr. Thomas Peake, of Cliff's End; it measured 7 feet across the wings, and was a 
remarkably fine and powerful bird. On being shot Mr. Pealie forced from its throat nearly $2 \mathrm{lbs}$. of large eels, and it is supposed that it gorged itself so much that it was careless of its safety, having been killed with a common charge of No. 4 shot." In the Zoologist, 1849, Mr. J. IV. Hullie, records that "on February 24, 1849, a large Eagle was seen hovering over the lower sandhills at Deal. From the description given by a person who lives there, it was most probably the White-tailed Eagle."

In the British Nuseum there is a young male which was obtained in Kient, and presented by Colonel Montagu. Dr. F. Plomley records a White-tailed Eagle in Kent, in the Zoologist, January 16, 1850. The Rev. C. H. Fielding states that one was obtained in Sheppey, but this is under the name of the Golden Eagle; and another at High Halstow, near Rochester, which he places under Erne or Sea-Eagle. Mr. WV. Prentis says: "A pair of Sea Eagles paid my district a visit in the month of November, 1879; the first was a fine large Eagle in mottled plumage and with a whitish tail. Another Eagle was soon afterwards seen flying 150 yards high over the district."

Mr. G. Dowlier, in his Birds of East Trent, 1889, gives a summary of these birds in that part of the county: viz.: One Sea-Eagle shot many years ago by the Rev. B. Austen, at Weatherless Hill, in the Minster marshes. Three obtained at nearly the same time, now in the Canterbury Museum, which $M r$. John Bing, of Grove Ferry, tells me he remembers having been shot near Chilham. The late Mr. C. Gordon, of Dover, remembers one obtained at Godmersham Park. The latest appearance of this bird in Kent was in 1885 ; between that. 
and the following year at least three were shot in the neighbourhood. The first at Minster, November, 1885, a fine female, 3 feet in length, and 8 feet in the stretch of wings. Soon after this another was shot near Eastwell Park, and is now in the possession of H.R.H. the Dulie of Edinburgh; this latter is a male, and a young bird. Sometime after the last bird had been shot another was seen the marshes, and it got away, but I find from a letter which appeared in Land and Water, January 28, 1888, that a similar bird was shot by a gentleman at Dover about the year 1885, and is now in the collection of Mr. Walter Bates, of Fulham. A White-tailed Eagle was captured in Eastwell Park on December 22, 1895 ; and another appears to have been obtained about the same time at St. Lawrence, Kent, if not the same bird.

On March 21, 1906, Mr. E. Bartlett observed a large White-tailed Eagle come up from Romney Marsh and pass over in a northerly direction towards Mersbam. It was very cold at the time, and had been snowing all the day.

\section{Genus ASTUR, Lacépède.}

\section{GOSHAWK.}

Astur palumbarius (Linnæus). S.N., i., p. 130 (1766).

The Goshawk is evidently a very rare bird in Kient, and the only instances recorded are as follows: The Rev. J. Pemberton Bartlett (1844) states that it is "not common. A good specimen was lately shot in a wood near Sprinfield Minnis, Kent." There is a Kentish specimen in the Exeter Museum, the bequest of the Rev. 
Bower-Scott, and according to the Rev. C. H. Fielding, one was taken at Lydd and was in the collection of Mr. Jell.

\section{Genus ACCIPITER Brisson.}

\section{SPARROW-HAWK.}

Accipiter nisus (Linnæus). S.N., i., p. 130

$$
\text { (1766). }
$$

This species is generally distributed over the county, but is not so numerous as formerly, especially in those parts of Kent which are Pheasant preserves. It still breeds in the larger and more secluded woods and plantations.

Mr. J. Gould, in his Birds of Great Britain, writes: "To give some idea of the impetuosity of the flight and stoop of the Sparrow-Hawk, I shall here insert a note on the subject, transinitted to me by IV. Oxenden Hammond, Esq., of St. Alban's Court, near Wingham, in Kent:-

" I once witnessed a circumstance wholly at variance with the creed of all falconers, who affirm that the true Falcons only stoop and strike their prey, while the shortwinged Hawks chase and clutch. Three or four years ago I was driving towards Dover, when suddenly a Sparrow-Hawk, with a stoop like a Falcon's, struck a Lark close to my horse's head. The Lark fell as a Grouse or a Partridge will fall to a Falcon or Tiercel; and the Sparrow-Hawk did not attempt to carry, but held on his way. I jumped down and picked up the body of the Lark and the head, the two being entirely disunited. The velocity and force of the stoop must have 
been tremendous. I have often seen Grouse and Partridges ripped up the back and neck, and the sliull laid bare; but I never saw a head taken clean off before." "

In February or March, 1902, Mr. R. J. Balston was lying up for Wood-Pigeons in Bishop's Wood, East Kent. A friend who was with him had a "decoy" up in an oak tree. A Sparrow-Hawk saw it and stooped to it, and when he found it was not a real bird he turned, but was shot.

Lord Clifton mentions a white Sparrow-Hawk, slightly mottled with brown, among the birds observed at Cobham, Kent.

Mr. A. Kennard, writing to the Zoologist, 1886, says : "This summer (1886), near Beckenham, Kent, I found a Sparrow-Hawk's nest in a fix tree, containing no less than eight eggs. The nest apparently was not an appropriated one, as is often the case, but was built by the Hawk. It was composed of sticks and lined with a few oak leaves. The number of eggs laid is sufticiently uuusual, I think."

In his notes on the birds of Kent (Zoologist, 1896), Captain Boyd Alexander gives the following details respecting the Sparrow-Hawk, which he says " is still numerous. The thicls portions of the Bedgebury and Hemsted Woods often defy the keeper's search, and cousequently not a few broods reared in these localities escape at least premature destruction. In this neighbourhood the nest is invariably placed at the base of two forked branches which jut out of the main stem of a fir or larch tree, and from 25 to 30 feet from the ground. The front of the nest always faces the warmer side, while the back is usually protected by the main stem of the tree. During winter the old nest is resorted to as a roosting place. 
In this way they often fall victims to the trap placed on the nest by the lieepers. By the time the breeding season comes round again the winter storms have reduced the nest to a mere ragged bundle of sticks. On this foundation the new nest is occasionally built, although the general custom of this species is to build an entirely new one. Many anthorities have stated that a deserted Crow's nest or Wood-Pigeon's nest is made use of. I have never found it to be the case in this neighbourhood."

Respecting the velocity of the flight of this species, a curious instance is related in the Daily Chronicle, March 14, 1907 :-

"Hawti's last Chase.-So great was the force with which a Sparrow-Hawk in chase of a small bird darted against a plate glass window at Lord Northbourne's Mansion, Betteshanger, near Deal, that a circular hole was smashed in the window, and the glass scattered to. a distance of 18 feet. The Hawk's neck was broken."

\section{Genus MILVUS, Curier.}

KITE.

Mitvus milvus (Linnæus). S.N., i., p. 126 (1766).

The Kite is now an extremely rare bird in Kent, although in days gone by it used to be a regular visitant. Boys, in 1792, includes this bird in his History of Sandwich. The Rev. J. Pemberton Bartlett, in 1814, states that it is "rare." According to Morris, one was obtained at Sydenham in 1835. There is a Kentish specimen in the Exeter Museum, the bequest of the Rev. Bower-Scott. 
Mr. G. Dowker, in his Birds of East Kent, says: "The Kite, 'Common' Kite, as it is sometimes called, is a very rare bird now. The old inhabitants of Canterbury used to see this beautiful bird sailing along over the Sturry Marshes, and there are some specimens in the Canterbury Museum that were probably shot in the neighbourhood. One of these birds was seen in 1867, and I believe one has been seen since."

Mr. R. T. Filmer states that "sometime about the year 1876, Mr. Washford, late of Ruckinge Railway Crossing and now of the Bridge Cottage, Ruckinge, pointed out to me a pair of these birds sailing around each other, far above the summer clouds" ; and the Rev. C. H. Fielding gives the following localities in which it has been observed: Cliffe (1881), Ramsgate (1887), and Rodmersham, Kent. Dr. A. G. Butler states: "I once saw this bird circling over a poultry yard at Sittingbourne, in Kent, but probably it was not hungry, as it suddenly turned and soared out of sight." Mr. G. Dowker, in his Birds of East Kent, 1889, writes: "Since writing my notes on this bird, a fine male specimen of the Kite has been killed in the neighbourhood (Stourmouth) and is in the possession of J. C. Kay, Esq., of Godmersham."

\section{Genus PERNIS, Cuvier.}

\section{HONEY-BUZZARD.}

Pernis apivorus (Linnæus). S.N., i., p. 30 (1766).

This species, like the Kite, is seldom met with in Kent, and is soon made a victim of its visits.

Boys, in his Birds of Sandwich, 1792, includes the Honey-Buzzard. Mr. J. P. Wilmot, in his notes on this 
bird in the Zoologist, 1844, p. 440, says: "When I was at Tunbridge Wells, some eight or ten years ago, I saw the handsomest specimen I ever did see of this species, in the possession of an amateur bird-stuffer of that place. He informed me that it was killed in Lord Abergavenny's park in the neighbourhood, and that within a few years preceding several specimens had been obtained in the same locality." In the Zoologist, 1844, the Rev. J. Pemberton Bartlett states that the kite is "rare, a specimen killed in the parish of Lydd is in Dr. F. Plomley's collection." There is a Kentish specimen in the Exeter Museum, the bequest of the Rev. Bower-Scott. The Rev. C. H. Fielding adds Cobham (1881); and a specimen, a female, was obtained at Teston, in Kent, in October, 1881, and presented to the Maidstone Museum by Mr. lioger Leigh.

In the summer of 1885 or 1886, Mr. R. T. Filmer states that for a long time a specimen of this rare bird was seen in or about Bourne Wood. Eventually it was trapped in a wasp's nest by Mr. J. Stickles, when its true nature was recognised.

\section{Genus HIEROFALC0, Cuvier.}

\section{ICELAND FALCON.}

\section{Hierofalco islandus (Gmelin). S.N., i., p. 271 (1788).}

The only record of the occurrence of this species (?) in Kent is that which is contained in the Rev. J. Pemberton Bartlett's Ornithology of Fient, 1844. He places it under the name of Ger Falcon (Falco islandicus), and says it is "rare," without any other particulars. 


\section{Genus FALC0, Linnæus.}

\section{PEREGRINE FALCON.}

\section{Falco peregrinus, Tunstall. Omith. Brit., p. 1 (1771).}

With all the persecution which so beautiful and interesting a bird as the Peregrine Falcon suffers from, it is wonderful how it persistently returns to its old haunts, and perseveres in rearing its brood, in the most dangerous proximity to man, for during the winter many of them are wantonly destroyed.

This bird is used chiefly by falconers and sportsmen, the male being called a "Tiercel," and the female a "Falcon."

In the Rev. J. Pemberton Bartlett's Ornithology of Kent, 1844, he states that it is "not uncommon in Romney Marsh, and occasionally to be seen about the cliffs near Dover." A male Peregrine was shot on December 9, 1856, in the parish of Halling, near Rochester, and is now in the possession of the Rev. C. IV. Shepherd. Lord Clifton, of Cobham Hall, writing in January, 1867, says: "A month or two ago the keepers here, attracted by a great confusion among some Rooks, came up and disturbed a large Peregrine Falcon from a Rook which she had knocked down. Soon afterward one of the men saw a Peregrine, probably the same, swooping down at some Pheasants that were feeding. I myself also saw a very large Hawk hovering about in the park, which, from its Falcon-like shape, I conjectured was the same bird."

Mr. F. D. Power, in his notes on the birds at Rain ham, Kent, during September and October, 1868, says: 
"One was seen by my brother on a marsh near the mouth of the Medway on October 1 ; it dashed down to a Dunlin that he had just wounded, but did not take it, and made off on receiving a long shot. In the winter of 1866-67 two Peregrines were obtained on this same marsh, and others have been seen occasionally, always in the winter months." Lord Clifton says: "On October 18 (1868) I saw a large Peregrine Falcon flying over Cobham Park. One was seen during the summer of 1870 ; another about December $31,1872 . "$

Mr. D. T. Button, of Gravesend, writing in February, 1872, says: "Three Peregrines have come under my notice since Christmas-one male, shot by a friend while rabbiting; one very large female, shot on the river, it had just killed a Ring Dotterel; and one fine young female shot last week on the river shore." There is a male in the Maidstone Museum, obtained at Marden, December 21, 1886, by $\mathrm{Mr}$. H. Tennard, and a male procured at Lenham Heath, in December, 1892, by $\mathrm{Mr}$. G. Haynes. Colonel H. W. Fielden, in his notes on the Cliff Birds at Dover, 1887, says: "A pair of Peregrine Falcons nest in the cliffs between Dover Castle and the South Foreland, and have, I believe, reared their young in safety this season. It has been a frequent source of pleasure to me during the past spring to visit these Falcons' breeding-place, as I invariably saw one, sometimes both, birds. The 'Tiercel' was wont to resent my intrusion, by flying overhead and screaming querulously ; at times he would wait on within 40 or 50 yards of me. These birds have shown me some good flights at Pigeons this year. I was at first somewhat puzzled where these Pigeons canie from, because all I saw flown at were evidently home-bred birds, and the Falcons always inter- 
cepted them as they were flying over the Channel. Placed on the edge of the cliff, I have watched a Pigeon flying with steady rapid flight over the Downs, heading southward across the sea. As the pigeon passes over the cliffs the Falcon dashes out seaward from under the cliff; the Pigeon sees its enemy and rises high in the air, the Falcon mounts as well; to the inexperienced eye the Hawk appears to be flying in an opposite direction to the Pigeon, but when he has gained the proper altitude down he swoops like a bolt from the sky, but the Pigeon eludes him by dropping with incredible rapidity to the sea. Again the Falcon rises, its evident intention being to drive the Pigeon to the shelter of the Kentish cliffs; the Pigeon, seeing its course across Channel barred by its mortal foe, seeks the shelter of the undercliff. The Falcon now has it all its own way, and the wings and slieletons of Pigeons which I have found at the base of the cliffs show what heavy toll the Peregrines levy on the Belgium and French Homing Pigeons returning to the Continent; for in several instances I found the name of the owner stamped upon the inside of the primary wing-feathers of the Pigeon, which proved to be trained birds belonging to Belgian owners."

There are two Peregrines in the Canterbury Museum, obtained in Kent in 1888, by Mr. IV. Oxenden Hammond. J. F. Green, Esq., of the "Cedars," Lee, Kent, has observed the Peregrine on that estate.

A male Peregrine is in the possession of $R$. D. de Uphaugh, Esq., of Hollingbourne House, Kent, which he says, writing in July, 1906, was shot about twenty years ago. 


\section{HOBBY.}

Falco subbuteo, Linneus. S.N., i., p. 127 (1766).

The Hobby is a comparatively rare species in Kent, and few instances of the discovery of the nest have been made. It is a very shy and wild bird, and is more often seen than obtained

Boys includes it in his Birds of Sandwich, 1792, and the Rev. J. Pemberton Bartlett, writing in 1844, states that it is "not uncommon." There is a Kentish specimen in the Exeter Museum, bequeathed by the Rev. Borrer-Scott. Mr. WV. Prentis says: "A pair of Hobbies in the year 1860 took possession of an old Magpie's nest on the top of a row of elm trees at Rainham, and they seem to have brought off their young in safety. In the month of June, 1864, a male Hobby was shot in a cherry orchard this side of Sittingbourne, and the female was seen."

Lord Clifton, in 1866, writes: "As the persevering extirpation of all birds of prey has made the Hobby rather rare, the fact of three being seen together may be of interest; they resort every year to a wood near Rochester, which is only used as a fox cover, where I observed them one day last August. Their cry is very shrill, unlike that of other Hawks, though sometimes they utter a note like that of the Kestrel's. They are extremely active and restless, continually chasing each other. There could be no doubt of this species, from the note and the length of the wings. They have seldom been shot at; I have only heard of one being killed; probably they breed there.

"On Angust 31, 1867, I revisited the wood where I saw the three Hobbies together last year, and saw 
two, if not three, there, certainly two together. If, as I infer, they breed there, the young birds must disperse themselves over the country, for we never see more than two or three. I was much pleased, on September 6, to meet with one close to Cobham, for the abovementioned wood is in quite a different district and on a different soil, quite isolated from other woods. This Hobby came over my head as I was returning from shooting. In the excitement of the moment I fired at him, but fortunately, owing to the height he was at, did not hurt him. On returning to the spot next day I found him as often as I liked, for he is by no means a timid Hawk, and spends most of his time in the air looking for prey, flying with outspread wings in graceful swoops. His Swift-like wings and short tail distinguish him from other small Hawks. I saw him hanging almost motionless in the face of the wind, rather like a Kestrel, scarcely moving the wings. On September 4, 1868, as usual, the Hobbies are to be seen in their old quarters, and the same number-three.

"I have not observed this bird in the immediate neighbourhood this year, 1871; but at the beginning of this month (September, 1871) three Hobbies, the invariable number, were seen at their old haunt, Chattenden Woods, in the parish of Frindsbury."

In 1902 and 1903 the Hobby was observed in the Orlestone district.

\section{MERLIN.}

Falco asalon, Tunstall. Ornith. Brit., p. 1 (1771). Blue Hawk.

The Merlin is only an autumn and winter visitor to Kent, generally keeping to the more open woods, leaving 
the county in the spring for its more northern breeding haunts. In Kent it is called the "Blue Hawl," from the slate-grey colour of its plumage.

In Mr. W. H. Power's Birds Observed at Rainham, Kent, he says: While walking on the marshes one day in September (1865) last, I heard some Redshanks in a creek making a great noise, evidently being in a state of great alarm; presently a single Redshank appeared, shooting along within a few feet of the surface of the mud, and shrieking with fear; close behind him came a Merlin in hot pursuit. The Redshank, in his terror, flew up a blind creek, and finding no outlet, settled on the mud, where he remained, while the Merlin wheeled over, without, however, attempting to strike him; but at length, catching sight of me, he went off, leaving the Redshank still on the mud, from which he did not attempt to move until I started him. 'The wonderful speed and activity of the Merlin were here well displayed by the manner in which he followed, in all its doublings, a bird of such rapid and irregular flight as a Redshank, and I fully believe the latter would hardly have escaped had not I appeared upon the scene."

Mrr. J. Hunter records a male Merlin that was shot at Faversham on November 3, 1868. According to Mr. F. D. Power, of Rainham, the "first Merlin observed was on October 12, 1868; but is a rare species here, although a pair used to frequent a particular wood every winter for some year's ; they first failed in 1867, and had not appeared this year at the end of October." There is a specimen in the Maidstone Museum obtained at Tovil, by Mr. H. Kennard. Lord Clifton says it was seen during the winter, and again in the spring of 1871. As usual, in November and December (1876), the gamekeepers here 
obtained a single female Merlin, which was found dead. Again in $\mathbf{1 8 7 5}$ he observed a Merlin on the marshes. On February 4, he says: "I saw a magnificent old male Merlin here (Cobham)." It is included in the Birds of Higham, by the Rev. C. H. Fielding.

A female was obtained in the Orlestone district, March 10, 1902, and another female in 1906. A male merlin was taken alive at Ivychurch, on December 28, 1906, by Mr. R. G. Rogers. This bird was blind with both eyes.

Genus TINNUNCULUS, Vieillot.

$$
\text { RED-FOOTED FALCON. }
$$

Timmunculus vespertinus (Linnæus). S.N., i., p. 129 (1766).

There appears to be only one authentic instance of the occurrence of the Red-footed Falcon in Kent, which is recorded in the Zoologist, 1862, by Mr. W. Oxenden Hammond, of St. Alban's Court, Wingham, Kent: "An adult female of the Orange-legged Hobby was killed at Sandling Park, near Hythe, in the early part of this summer. I saw the bird soon after, but as I believe its occurrence in this instance has not been recorded, I asked permission to notify it."

In the Zoologist, 1871, Lord Clifton gives a long account of a supposed pair of Orange-legged Hobbies which he saw at Cobham in August, 1869. 


\section{KESTREL.}

Timnunculus timmunculus (Linnæus). S.N., i.,

$$
\text { p. } 127 \text { (1766). }
$$

Windsucker, Windbibber, Wind-hover.

The well-known Kestrel is distributed sparingly throughout the county, and breeds in all the most suitable localities.

The Rev. J. Pemberton Bartlett, writing in 1844, states that "the Kestrel is the commonest of all the Hawk tribe which we have in Kent, and is known commonly by the name of Wind-hover, from the extraordinary power it possesses of poising itself in mid-air, and during very high winds; from whence also, in some counties, it is called 'Stannel' or 'Stand Gale.' The Kestrel is included in the Birds Observed at Rainham, by $\mathrm{Mr}$. W. H. Power, who says: "A pair of these birds in the autumn took possession of the roof of a solitary shed that had been erected on the marshes for the use of the cattle. For this post of observation a flock of Starlings continually contended, and numerous were the skirmishes that took place, very often ending in the Kiestrels being driven off for a time. Although I constantly saw one or other of these Kestrels apparently surrounded by the Starings, yet I never observed the slightest attempt on their part to retaliate by striking at any of their tormentors."

Mr. J. Hunter, of Faversham, writing on the large game of the Kestrel, says: "On November 28, 1867, when strolling over the cliffs near Herne Bay, I disturbed a Kestrel at his dinner, which on examination, I found to consist of a Hooded Crow. He had eaten all but the 
skin and head, over which latter he was neatly turning the skin to finish. The eyes of the Crow were quite bright, and the bird had evidently not long been dead. In the same field there were many Hooded Crows feeding, quite unconcerned at the presence of the enemy." It is doubtful whether the Kestrel would attempt to kill a bird like the Hooded Crow, it must have been found dead by the Fiestrel.

In Mr. J. E. Harting's Handbook of British Birds, 1901 , it is stated that the "Kestrel occasionally nests in hollow trees, as at Bromley in Kent, in 1876, when six eggs were found in one nest, the usual number being five."

Lord Clifton, writing on the late assumption of the adult plumage by the male Festrel, says: "About the second week in January, 1877, a male Kestrel was shot here (Cobham) which was hardly distinguishable from an old female, except in the slightly smaller size and a warm tone of rufous on the back. The tail was slightly washed with blue, but not so much as in some old females. Even the upper tail-coverts were rufous, and the feathers on the nape were whitish, forming rather a Merlin-like collar. I took it at first for a small female." The bird mentioned above was evidently in the second moult, and would not assume its full colours until the spring.

Three nestling Kestrels were obtained in Kent, and reared, and turned out to be males. It was not until the second moult that one of them assumed the blue head, yet all three were males from the same nest.

The Kestrel breeds in the old chalk-pits or cliffs on the Boxley Hills, and also in the cliffs near Broadstairs. They do occasionally take a young Pheasant from the coops. 
The following note is taken from the Daily Chronicle, August 13, 1906: "A pair of Tiestrels have built a nest on the cliffs between Folliestone and Dover. A local naturalist, who was watching the birds on Saturday, had a trying experience. One of them suddenly flew up and began to circle about him, and was shortly joined by its mate. The Hawks got closer and closer, and their attitude was so threatening that the naturalist made his way to Lydden Spout coastguard station for shelter. The coastguards say that the birds have given a similar scare to several who have shown too close an interest in their nest."

Mr. G. Dowlier, in his Birds of East Iint, says: "As an instance of the usefulness of this bird, I may relate that my son was one day out Partridge shooting, and saw hovering over a turnip field a Kestrel, which he shot, when immediately a covey of Partridges arose. He brought it home to me in proof of its destructive qualities. I assured him it would not kill any bird so large as a Partridge, and on opening it I found its crop filled with caterpillars, and I found the same caterpillars in abundance in the turnip field."

\section{LESSER KESTREL.}

Tinnunculus cenchris (Naumann). Tög. Deutsch., i., p. 313 (1822).

There is but one record at present of the occurrence of the Lesser Fiestrel in Kent, which is to be found in the Zoologist, 1877, as follows: The late Mr. C. Gordon (May 22, 1877) states that "Mr. E. P. Robinson has lately presented to the Dover Museum a specimen of the 


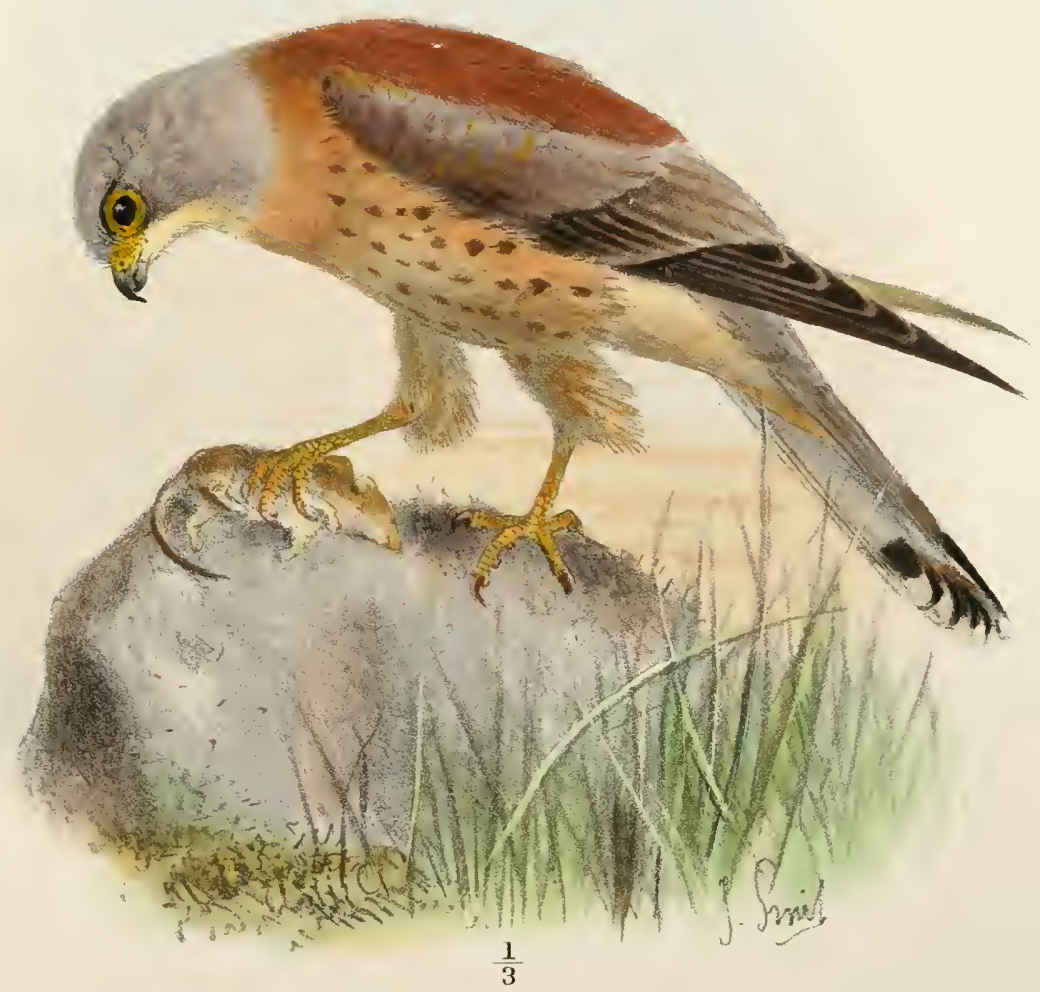

J Srrit del et lith. Baie \& Daniels s on, Lta imp

LESSER KESTREL

TINNUNCULUS CENCHRIS (Naum) 

Lesser Kestrel, which was caught alive and kept for a short time in confinement by a labourer on his farm in the neighbourhood of Dover. The bird, which proved to be an adult male, had one leg injured, which may have prevented it from taking its natural prey and led to its capture. In appearance it differs from the Common Kestrel. In the first place, it has no markings on the back, the colour being one rich reddish-brown. The breast is light red, with a few markings, the more distinct ones being on the thigh-coverts; the head and tail light ash-grey, the latter with a broad black band at the extremity, and each feather edged with white except the two centre ones, which are black at the tips. The claws are white."

Genus PANDION, Savigny.

\section{OSPREY.}

\section{Pandion haliaëtus (Linnæus). S.N., i., p. 129 (1766).}

There is a specimen that was lilled at Bearsted, in Kent, in the Exeter Museum, the bequest of the Rev. Bower-Scott. The Rev. J. Pemberton Bartlett, writing in 1844, says: "A specimen in the Dover Museum was shot in the neighbourhood, September 8, 1871." Mr. G. E. Power says: "I obtained a specimen of the Osprey in some marshes near Rainham. It is a male, and apparently an immature bird. When I first saw it some Peewits were following and mobbing it; afterwards it settled on some saltings near the sea-wall, from which I obtained an easy shot." Mr. G. Dowker records one 
procured by the Rev. B. Austen from the Isle of Thanet. Mr. W. Prentis mentions one in the parish of Upchurch, near Rainham. The Rev. C. H. Fielding gives Cobham as a locality in which it bad been found.

One was seen at Boxley, Kent, by the Rev. H. W. Trower, on Sunday, September 9, 1894, in Major Best's park. This, no doubt, was the bird that was secured in Mote Park on September 10, 1894. Mr. H. Elgar gives the following measurements of it: Length 23.6 ; tail 10.3 ; wing $19 \cdot 2$; tarsus $2 \cdot 3$; culmen $1 \cdot 6$. It was an immature female.

\section{Family PELECANIDÆ.}

Genus PHALACROCORAX, Brisson.

\section{CORMORANT.}

\section{Phalacrocorax carbo (Linnæus). S.N., i., p. 216 (1766). \\ Coal Goose.}

This powerful diver and swimmer may be seen more often than obtained along the coast of Kent. It is only an occasional visitor, and the majority of specimens procured are immature birds.

It is included in Boys' Birds of Sandwich, 1792. The Rev. J. Pemberton Bartlett, writing in 1844, states that it is rare, "a specimen shot in Romney Marsh is preserved in Dr. F. Plomley's collection.” Mr. G. Dowker, in the Birds of East Kent, says: "The Cormorant is only a visitor to our shores." 
There is a female in Mr. Henry Payne's collection, which was shot at Gillingham, January 5, 1894, and Mr. H. Elgar states that the gular pouch contained three viviparous Blenny, length 8.5 and 4 inches.

Mr. WV. Prentis, writing in 1894, says: "It is only during the last five or six years that the Cormorant has become plentiful on our river, the Medway; it may be that they are getting more numerous round the coast."

Mr. J. E. Green, in his notes on the birds of the "Cedars," Lee, Kent, gives a solitary instance of the Cormorant having visited that estate.

A Cormorant was taken in the Hythe Canal by Mr. F. Young, in October, 1870, and recorded by the late Mr. C. Gordon.

\section{SHAG.}

Phalacrocorax graculus (Linnæus). S.N., i., p. 217 (1766).

\section{Cole Goose.}

This species, being one of our most northern birds, and being able to stand the most severe weather, is seldom found in the estuaries of our rivers, being more often found on the rocky coast, keeping always out at sea.

The Shag is included in Boys' Birds of Sandwich, 1792.

Mr. W. Prentis says: "The Shag has, to my knowledge, been observed on the Medway and shot on one or two occasions." 


\section{Genus SULA, Brisson.}

\section{GANNET.}

Sula bassana (Linnæus). S.N., i., p. 217 (1766). Solan Goose.

The Gannet is frequently seen along the coast of Kent, and has been obtained on many occasions, not only on the sea-coast, but accidentally inland.

Boys, in his History of Sandwich, 1792, records two instances at Sandwich and Dover. The Rev. J. Pemberton Bartlett, in 1844, states that it is "common" in Romney Marsh, which is confirmed by the following account, which I have received from Dr. F. Plomley. "In westerly winds," he says, "the Gannet is very commonly driven on shore. I have had very many fine specimens brought to me, one of which I sent to the Zoological Gardens a year or two since."

Mr. R. O. White, writing on March 5, 1847, from Dart. ford, says: "A few days since a Gannet was brought to me which had been captured by a shepherd in a turnip field, about three miles from this place. The man had much difficulty in securing it, and his hands were torn in many places by its beak. The fact of it not flying when he approached it, and of there being no food in its stomach, induced me to suppose it was weakened by hunger. I hardly know whether the circumstance is worth writing about, but I have neither seen nor heard of it occurring so far up the Thames, and the field in which it was caught was fully five miles from the river."

In $1868 \mathrm{Mr}$. John Hunter says that "at the end of September, 1867, a man found a Gannet, in the 
plumage of the first year, behind the sea-wall on Whitstable Flats. The bird, although apparently unwounded, was stupid enough to allow itself to be knocked on the head with a stick."

One was killed by a fox on the hills near Trosley, Kent; it was supposed to have been blown inland by a heavy gale: A labourer made a pie of it, thinking it was a wild goose.

The audacity of the Gannet is reported in several newspapers. On Saturday, December 22, 1906, "an angler, while fishing at Dover, captured a fine Gannet, which swooped down and took his catch, hook and all."

\section{Family ARDEIDÆE. \\ Genus ARDEA, Brisson. HERON.}

Ardea cinerea, Linnæus. S.N., i., p. 236 (1766). Hern, Grey Hern.

The Heron is well known throughout the county, and may be seen on all the large rivers, lakes, and along the sea-coast nearly all the year round, but not in large numbers.

Mr. W. H. Power, in his Birds Observed at Rainham, states: "Young birds of this species were common during July, 1866, but were, as usual, very shy. I only succeeded in getting at them once, shooting two one morning before breakfast. On July $10 \mathrm{I}$ saw five flying together."

In Lord Darnley's park at Cobham there is a Heronry 
which is very old. Mrr. G. Dowker, in his Birds of East Kent, says: "We have one Heronry at Chilham Castle, which is known to have been in existence for the last one hundred and twenty years; they build here in lofty beech and ash trees, and they make their nests in the highest branches, nearly 100 feet from the ground; at present (1889) there are about seventy birds in the breeding season."

Mr. J. E. Harting (Zoologist, 1872) states that "in the grounds of P. R. Hoare, Esq., at Kelsey Manor, Beckenham, Kent, there are always one or two nests annually, built in very aged Scotch firs, which hang over the lake." There is another in Penshurst Park. Mr. R. G. Rogers procured a Heron at Snargate on January 2, 1907.

\section{PURPLE HERON.}

Ardea purpurea, Linnæus. S.N., i., p. 236 (1766).

This species is a rare visitor to Kent, and it is some years since one has been seen or obtained. Dr. F. Plomley, writing in 1847 , states that he procured a young bird at Lydd in September, 1838, and also "a splendid specimen in the most perfect plumage, which was shot at Lydd, in Romney Marsh, March 26 (1847), and is in my collection." These birds are in his collection in the Dover Museum.

Mr. W. Prentis mentions an immature bird that was shot some years ago near the River Swale. 


\section{GREAT WHITE HERON.}

Ardea alba, Linnæus. S.N., i., p. 239 (1766).

Writing in 1844, the Rev. J. Pemberton Bartlett states that the Great White Heron "has been seen in Romney Marsh." And Mr. J. B. Ellman, in writing to the Zoologist, 1849, says: "A wild-fowl shooter yesterday (March 4, 1849) informed me that during the last moon he shot at a White Heron in Romney Marsh, while after wild-fowl; but it was so shy that he could not get near enough to kill it. He said it was as large as a common Heron, and white all over. I at first thought he was mistaken, and suggested it to have been a Spoonbill, but he says not, as he knows that bird well, and is positive the one he saw was a White Heron."

\section{BUFF-BACKED HERON.}

Ardea bubulcus, Audouin. Expl. Somm. Pl. Ois.

$$
\text { de l'Egypte, i., p. } 298 \text { (1825). }
$$

There is a specimen of this species in the Maidstone Museum labelled Kent, presented by Mr. G. Simmons, and without data.

\section{SQUACCO HERON.}

Ardea ralloides, Scopoli. Ann. I. Hist. Nat.,

$$
\text { p. 88, No. } 121 \text { (1769). }
$$

Dr. N. F. Ticehurst records that on June 19, 1903, "an adult female Squacco Heron was shot near East Guildford, in Romney Marsh"; this part of the Marsh is in Sussex, but is under the jurisdiction of Kent. 


\section{Genus ARDETTA, G. R. Gray.}

\section{LITTLE BITTERN.}

Ardetta minuta (Linnæus). S.N., i., p. 240 (1766).

Very few instances of the occurrence of the Little Bittern have been mentioned in Kent.

The Rev. J. Pemberton Bartlett, writing in 1844, says: "It has been shot in Kent." There is a specimen in the Exeter Museum obtained in Kent, the bequest of the Rev. Bower-Scott; another obtained at Preston Marshes in Mr. W. Oxenden Hammond's collection, now in the Canterbury Museum; and one procured at Elmstone, in the Rev. WV. B. Delmar's collection.

\section{Genus NYCTICORAX, Stephens.}

NIGHT-HERON.

Nycticorax griseus (Linnæus). S.N., i., p. 329 (1766).

Several instances are recorded of the Night-Heron in Kent.

The Rev. J. Pemberton Bartlett, in 1844, states that "one or two specimens have been obtained in Kent. Dr. F. Plomley has one which was shot in the parish of Lydd." There is one which was obtained in Kent in the Exeter Museum, the bequest of the Rev. Bower-Scott. Two Kentish specimens are in the Maidstone Museum, presented by Mr. G. Simmons. Mr. G. Dowker records it from Minster in 1882.

At a meeting of the Zoological Society, held January 15, 1884, the Secretary exhibited, on behalf of Mrr. H. 
Whitely, an immature bird of the Night-Heron, which had been shot in Plumstead Marshes, Kent, in December, 1883.

\section{Genus BoTAUURS, Stephens.}

BITTERN.

Botaurus stellaris (Linnæus). S.N., i., p. 239 (1776).

The Bittern was a frequent visitor to Kent before the draining of the large marshes, but even now they are occasionally taken in the more secluded lakes and overgrown swamps.

Boys includes it in the Birds of Sandwich, 1792. The Rev. J. Pemberton Bartlett, writing in 1844, says it is "not common." It is recorded from Cobham in 1848. A female was shot at Swanscombe in 1853 , and recorded by Mr. W. Cooke. Mr. E. Newman mentions an extremely fine male which was lilled in 1864 at Orpington, Kent, and another in Kent in 1875. Mr. G. Dowker adds it to the birds of Stourmouth. A specimen now in the collection of $\mathrm{Mr}$. WV. Oxenden Hammond, at Canterbury, was obtained at Wadnall Wood, Everington, Kent. It was obtained at Queensborough and Stoke in 1884; Snodland and Cooling in 1890. Mr. R. J. Balston procured it at Headcorn, January 4, 1890, and another at Pluckley, Kient, December 22, 1899 ; the former is in the Maidstone Museum, the latter was spoilt, as the retriever would not fetch it off the ice, which was too thin for a man to venture upon, eventually it was got when the ice was gone.

Mr. A. B. Farn, in writing to the Zoologist, 1899, says : 
"On the morning of January 14, 1897, a Mr. Nettlingham, having occasion to go about some wood which had been cut in Darenth Wood, near Dartford, noticed what he at first thought was a hen Pheasant. Closer observation, however, proved that this was not the case. The bird was sitting with drooping wings, neck and head laid along the back, and with the beak pointed straight upwards. Arming himself with a few stones he approached the bird and knocked it down at once. I saw it alive the same evening, but it died the next morning. This is the second specimen of this species I have seen, and the third I have heard of as occurring in this neighbourhood within the last few years."

Mr. IV. Prentis states that it has been shot on four occasions in the Rainham district.

Mr. H. Elgar writes " that Mr. Boucher, of Maidstone, has a Bittern which was shot at Aylesford on January 14, 1907."

\section{AMERICAN BITTERN.}

Botaurus lentiginosus (Montagu). Suppl. to Omith. Dict. (1813).

IIr. J. H. Gurney recorded in the Field an American Bittern which he discovered at Canterbury, and the following is culled from the Zoologist, 1866; he says: "I saw a stuffed specimen of the North American Bittern in the shop of Mr. Craig, bird-stuffer at Canterbury, who appeared to consider it as only a small example of the common Bittern, and who informed me that it was killed twelve years ago (1854), about 3 miles from the city of Canterbury. As I had no means of testing the accuracy 
of this statement, and as the specimen was in bad order from dust and exposure, I did not enquire if it was for sale."

\section{Family CICONIIDE. \\ Genus CICONIA, Brisson. \\ WHITE STORK.}

Ciconia ciconia (Linnæus). S.N., i., p. 235 (1766).

The White Stork is a comparatively rare visitor to Kent, and few records of its occurrence have been made.

Boys, in his Birds of Sandwich, 1792, gives a "single instance at Sandwich."

The Rev. J. Pemberton Bartlett, 1844, says: "It is rare. A specimen is in Dr. F. Plomley's collection." This bird was obtained in Romney Marsh, and is now in the Dover Museum.

Mr. J. H. Gurney states that "on March 18, 1871 (as I learn from Mr. Gasson), a White Stork was shot by Mr. Hearsfield at a low swampy place near Lydd, in Kent, called 'Fairfield Brack,' within 40 rods of where a Black Stork was shot fifteen years ago. These birds were preserved by Mr. G. Jell, who on May 10, 1871, sent to me a White Stork in the flesh, which was killed about the 8th, by Mr. James Lording, in the parish of Midley, also close to Lydd. It was walking about in a field quite away from any water, and four or five miles from the sea."

The Rev. C. H. Fielding adds Chalk as a locality for this bird, and Mr. Howard Saunders says that a young bird was shot in September, 1882, in Kent. 


\section{BLACK STORK.}

Ciconia nigra (Linnæus). S.N., i., p. 235 (1766).

The Rev. J. Pemberton Bartlett, in his Birds of Kent, 1844, states that this species "has been killed in Kent," and most likely it was one that was found in Romney Marsh prior to the above date, and now in the collection of Mr. Thornhill, of Riddlesworth. About October, 1852, another was recorded by Mr. Chaffey, of Dodington, which was killed in the Weald of Kent.

In the Zoologist, May 30, 1856, Mr. R. N. Dennis writes: "Being at Lydd, in Kent, on May 21, I saw at the shop of a bird-preserver there, of the name of George Jell, a fine specimen of the Black Stork, which had been lilled on or about May 5, 1856, at a place called Fairfield Brack, near Brenzet, and but a few miles from Lydd. The account which he gave me of the capture of the bird was the following: Two labourers had noticed what they supposed to be a very big Heron about a certain spot for three weeks; at last one said to the other, 'Heron makes an uncommon pudding, let us try to shoot it.' The attempt was made and the bird was shot, and forwarded by the person into whose hands it fell to Mr. G. Jell. It is in the collection of Mr. Clifton Simmons."

Black Stork near Rainham._-"About the beginning of July (1884) a large Heron-like bird, with black back and belly white, was seen by a shepherd on an island marsh near here. On September $8 \mathrm{Mr}$. Charles Gordon, of Dover, being at my house, we happened to go on the same marsh to shoot, and beside the shepherd's house on the creek shore we found a skin of a bird very much 
decayed, which Mr. Gordon pronounced to be the skin of a Black Stork. From its appearance we assumed that it must have been lying there for about six weeks, floating on the shore with the tide. I picked up the pinion of one wing, one foot, and the skull. On questioning the man he said that he had captured it at a small plash of water where eels had collected, all the rest of the ditches in the marsh, from the long warm dry weather, being quite dried up." - Walter Prentis, Rainham (Zoologist, 1884, p. 429).

\section{Family PLATALEIDA.}

\section{Genus PLATALEA, Linnæus.}

\section{SPOONBILI.}

Platalea leucorodia, Linnæus. S.N., i., p. 231 (1766).

The Spoonbill was formerly very numerous in Kent, and it is supposed that they bred in the county, especially in the old Heronry at Cobham Hall. Of late years they have become only occasional visitors, and are nearly always victims of their visit.

In Pennant's Zoology, 1812, it is stated that the Spoonbill was met with by "Boys on the Kentish Coast, but it is not included in his Birds of Sandwich, and that another was met with at Greenwich in August."

The Rev. J. Pemberton Bartlett, in 1844, says: "This very rare straggler has been killed in Romney Marsh, and is in Dr. F. Plomley's collection." Mr. J. W. Hulke, of Deal, writing to the Zoologist, June 17, 1850, says: "A flock of six Spoonbills has frequented Sandwich 
Haven; one of them has been shot by a person of Sandwich, and another in the Wingham Marshes (this is the bird, no doubt, which was procured by Mr. W. O. Hammond in 1850), the latter was an old female; both were shot in the first week of June. My friend saw three flying about in Pegwell Bay a few days since, but was not able to get near them."

There is a specimen in the British Museum, which was obtained in Romney Marsh in September, by Dr. Gordon Hogg.

Mr. W. Prentis, in his Birds of Rainham, mentions " a fine adult Spoonbill, with a buff collar and pendant crest, that was shot on the Isle of Elmley, April 12, 1865, and that immature specimens have been met with on three occasions in the marshes near the River Medway."

From a note in Mr. J. Gould's Birds of Great Britain, it appears that Mr. F. Bond told him that two Spoonbills had been shot on October 12, 1864, near Lydd, in Kent.

In his Ornithological Notes from Romney Marsh, Captain Boyd Alexander says: "On June 12, 1896, a White Spoonbill appeared near the Midrips. Its appearance created considerable excitement amongst several of the fisherfolk. I have the following records of the occurrence of the Spoonbill in this locality: Two adult males were shot, May 9, 1889, by two of the Southerden family. One of these specimens was subsequently sold to Mr. G. Gray, of Dover, for $£ 7$. In June, 1890, a party of five Spoonbills appeared; but, to use the words of the fishermen, "We were too greedy; we wanted the blooming lot, and ended by getting none.' On May 24, 1891, an immature bird was obtained. The bird now in question was at the time of its being seen feeding along with five Herons. I have also observed this species on the sand in company with Gulls." 
Dr. N. F. Ticehurst records a "young male Spoonbill which was shot on October 25, 1902, at Broomhill, in Romney Marsh. It was a very small bird. Mr. Chapman, of Rye, to whom the bird now belongs, informs me that it was shot just on the Sussex side of the Kent ditch."

\section{Genus PLEGADIS, Kaup.}

\section{GLOSSY IBIS.}

Plegadis falcinellus (Linnæus). S.N., i., p. 241 (1766).

The Glossy Ibis is a rare visitor to this county. Morris records that Mr. Arthur Havers, of Tenterden, Kent, says that one was killed near Reading Street, on the border of Romney Marsh, Kent, in December, 1852; another near Dartford, 1837, and one at Swanscombe, Kent.

Dr. N. F. Ticehurst states that a young Glossy Ibis was shot at East Guildford, in Romney Marsh, on October 14, 1902.

\section{Family PHENICOPTERIDE. Genus PHENICOPTERUS, Linnæus.} FLAMINGO.

Phanicopterus roseus, Pallas. Zoograptia RossoAsiatica, ii., p. 207 (1811).

The Flamingo, like a great many more of the European and African birds, will by accident cross the Channel, therefore it is not surprising to find an occasional 
Flamingo, but in many instances they may be escaped birds. 'The first record of one having been taken was at Elmley, in the Isle of Sheppey, on or about August 7, 1873, by Mr. A. J. Jackson. It was afterwards stated by Mr. E. Newman that one of the Flamingoes had escaped from the Zoological Society's Gardens two or three days previous to its capture at Elmley.

But the most important record of the Flamingo in Kent is that of Captain G. E. Shelley, published in Yarrell's British Birds, who "informed the editor that on August 12, 1884, when waiting for the evening flight of Curlew, near New Romney, an adult Flamingo flew past with outstretched neck and legs in a south-easterly direction, its red wings and black primaries showing clearly in the light of the setting sun; and his two nephews, who put the bird up, told him they got within fifty yards of it while it was feeding by the sea amongst a flock of Gulls."

\section{Family ANATIDE. \\ Genus CHENALOPEX, Stephens.}

EGYPTIAN GOOSE.

Chenalopax agyptiacus (Linnæus). S.N., i., p. 197 (1766).

\section{Crocker Goose.}

In the Zoologist, 1846, Dr. F. Plomley records the occurrence of " a flock of five Egyptian Geese which had been ranging about Romney Marsh for some few days, but so wild that a specimen could not be obtained; these birds were formerly very common, and are well known to 
the old wild-fowl shooters by the name of the "Crocker Goose." "The above was written by Dr. F. Plomley, at Lydd, Romney Marsh, Kent, July 18, 1846.

\section{Genus ANSER, Brisson.}

\section{GREY-LAG GOOSE.}

Anser anser (Linnæus). S.N., i., p. 197 (1766).

This Goose is a winter visitor to the sea-coast and large marshes of Kent, and has been recorded by the following: Boys includes it in his Birds of Sandwich, 1792. The Rev. J. Pemberton Bartlett says it is "common in Romney Narsh," this was written in 1844. Dr. F. Plomley obtained it, and Mr. C. Gordon procured it at Dover. Mr. G. Dowker mentions it among the birds of the Stourmouth district. Mr. R. T. Filmer states that it is a rare visitor to Romney Marsh. The Rev. C. H. Fielding gives Rainham Marshes as a locality.

\section{BEAN-GOOSE.}

Anser segetum (Gmelin). S.N., i., p. 512 (1788).

The Bean-Goose visits the sea-coast of Kent during the winter, and is often obtained during very severe winters.

Boys adds it to his Birds of Sandwich, 1792. The Rev. J. Pemberton Bartlett, writing in 1844, says it is "common in Romney Marsh." Those days are gone. It is recorded by the Rev. WV. B. Delmar, of Elmstone; Mr. H. Ullyett, at Folkestone; Dr. F. Plomley, from Romney Marsh; and Mr. G. Dowker, at Stourmouth, 1887. 


\section{PINK-FOOTED GOOSE.}

Anser brachyrluynchus, Baillon. Mém. de la Soc. Roy. d'Em. al Abber., 1833, p. 74.

This species is occasionally found on the sea-coast of Kent; at the same time, it may be overlooked, as Mr. G. Dowker remarks in the subjoined note: "I doubt not that the Pink-footed Goose has frequently been confounded with the Bean-Goose, to which it bears a general resemblance. I obtained one at Preston in 1887: I find it is not noticed by any other authorities in Kent."

\section{WHITE-FRONTED GOOSE.}

Anser albifrons (Scopoli). Ann. I. Hist. Nat., p. 69, No. 87 (1769).

This species is a regular winter visitor and has been known to breed in the county.

It is included in the Birds of Sandwich by Boys, 1792. The Rev. J. Pemberton Bartlett, writing in 184t, says it is "common in Romney Marsh." Mr. G. Dowker" states that it is a "visitor to the Stourmouth district." It is also recorded at Dover by Mr. C. Gordon and $\mathrm{Mr}$. G. Gray. J. F. Green, Esq., in his Fauna of the "Cedars," Lee, Kent, 1905, says the "Wild Geese (Anser albifrons) which are not pinioned, nest at the pond regularly. They eat nothing but weeds and grasses. They are sometimes accompanied by a Heron." 


\section{Genus BERNICLA, Boie.}

\section{BRENT GOOSE.}

Bernicla bernicla (Linnæus). S.N., i., p. 198 (1766).

Clatter Goose.

The Brent Goose is the best known of the species on the coast of Kent, generally appearing in flocks, and entering most of the rivers and creeks for shelter from severe weather.

Boys includes it in the Birls of Sandwich, 1792, where it is called the "Clatter Goose." The Rev. J. Pemberton Bartlett states that it " has been seen in Romney Marsh."

Mr. G. Dowker says it is a "common winter visitor to the Stourmouth district." It is also recorded by $\mathrm{Mr}$. C. Gordon from Dover, the Rev. B. Austen at Walmer, and Dr. F. Plomley from Romney Marsh. Mr. TV. Prentis says it "comes into the Rainham creeks in severe winters in small numbers. There are two specimens in the Maidstone Museum which were obtained by Mr. R. J. Balston in the Swale.

\section{BARNACLE GOOSE.}

Bernicla leucopsis (Bechstein). Orn. Taschenb., ii., p. $42 \pm$ (1803).

This is evidently the rarest of our winter Geese on the coast of Fient, and appears to be almost unknown, especially of late years. Boys adds this species to the Birds of Sandwich, 1792. The Rev. J. Pemberton Bartlett states that it "has been seen in Romney 
Marsh." Mr. G. Dowker, in his Birds of East Kent, says the "Barnacle Geese seldom visit the inland waters and are mostly found at sea."

\section{CANADA GOOSE.}

\section{Bernicla canadensis (Linnæus). S'N., i., p. 198 (1766).}

There is no reason to doubt that this powerful bird of flight comes to this country from its North American home. Of all the smaller and weaker North American birds which have accidently appeared in the British Islands and are admitted among the British birds, why should this species be excluded? On the authority of Mr. G. Dowker, a Canada Goose was obtained at Beachborough by Mr. W. Oxenden Hammond.

In the Zoologist, 1898, Mr. G. W. Bradshaw writes: "I had sent to me in the flesh two specimens of the Canada Goose (Bermicla canadensis), on April 26, 1898, which were shot ont of a flock of five on the sands near Dungeness, Kent, about a week before. They show no signs of having been pinioned. They flew in from the sea. The heaviest one was a male, and weighed, a week after death, 10 lbs. 8 ozs.

Genus CYGNUS, Bechstein. MUTE SWAN.

Cynus olor (Grmelin). S.N., i., p. 501 (1788).

The well-known Tame or Mute Swan of our rivers and lakes, unless pinioned, finds its way all over the country, and is therefore, especially on the sea-coast, 
often taken for a wild bird and shot, at the same time there is no doubt additions that occasionally arrive from the far north during severe winters. As is well known, this semi-domesticated Swan is foumd in large numbers in a wild state in Norther'n Europe during the breeding season, and visits most of the southern parts during the winter.

Boys includes this Swan in his Birds of Sandwich, 1792. Mr. G. Dowker mentions it at Stourmouth, and says: "Probably an escape from confinement."

\section{POLISH SWAN.}

Cygmus immutabilis, Yarrell. Proc. Zool. Soc., 1838, p. 19.

In 1838, Mr. William Yarrell "exhibited a specimen of this Swan at an evening meeting of the Zoological Society, belonging to the Rev. L. B. Larking, of Ryarsh Vicarage, near Maidstone, which was one of four shot on the Medway, near Snodland Church, where a flock of thirty and several smaller flocks were seen." Mr. Yarrell then pointed out the distinctive characters of the bird, and described it as a new species.

\section{WHOOPER SWAN.}

C'ygnus cygnus (Linnæus). S.N., i., p. 194 (1766).

The Whooper Swan has been more often seen and obtained in Kent than the Polish Swan, but the numbers greatly depend upon the severity of the winters in Northern Europe.

Boys includes it in his Birds of Sandwich, 1792. 
Morris says: "In the year 1848 many were seen and not a few killed in Kent, near Gravesend." There is a specimen in Dyke Road Mnseum which was shot in Romney Marsh in Kent, during the winter of 1859-60.

Mr. H. J. Harding, of Deal, writing to the Zoologist, 1871, says: "During the late frost about nine Swans visited the Marshes near Deal; three were shot, but they were in very poor condition, weighing about 15 lbs.; one was a Black Swan." This latter bird had escaped from confinement.

"The following are the dimensions of a Wild Swan (Cygmus ferus) shot by me while cruising in the yacht 'Scout,' on the Medway, on February 15, 1879. From tip to tip of wings, 7 feet 5 inches; from point of beak to point of tail feathers, 4 feet 5 inches; weight, $16 \frac{1}{2} \mathrm{lbs}$. The bird flew across the bow of my boat, and was killed by the first barrel of an 8-bore breech-loader. The yellow on the upper part of the beak (the distinguishing mark of a Whooper, or Wild Swan) was of a deep orange colour, showing him to be an old bird."-W. S. N., Morning Telegraph, March 1, 1879.

Dr. F. Plomley found it in Romney Marsh, Mr. C. Gordon at Dover, and Mr. G. Dowker at Stourmouth.

About 1860 Mr. R. J. Balston shot one (immature) on the Medway near New Hythe, below Aylesford.

\section{BEWICK'S STIN.}

Cygnus bewictii, Yarrell. Trans. Limn. Soc., xvi., p. 445 (18:33).

Bewick's Swan is a winter visitor, and has been obtained in Kent on several occasions, but it is not so numerous a species in the county as it sometimes is in the Nortl. 
The Rev. C. H. Fielding records it from Lidsing Woods, near Gillingham, in Kent. The Rev. J. Pemberton Bartlett, writing in 184t, states that Dr. F. Plomley "has a specimen in his collection which was killed in Romney Marsh. One was shot by a labouring man in the parish of Kingston, in Kent, a few years since."

A specimen in Mr. IV. Oxenden Hammond's collection at Canterbury was obtained at Bourne Park, February 21, 1855. Messrs. C. Gordon and G. Gray record it from Dover, Mr. H. Ullyett at Folkestone, and Mr. G. Dowkel at Stourmouth.

Mr. W. I'rentis writes: "On January 22, 1879, an excellent specimen was shot in an extraordinary way. Some shooters were lying in wait for Sea-Gulls in the shelter of a wood at Rainham, the Gulls returning from the fields which had been manured with sprats, when a Swan came flying in the same direction, following the track of the Gulls, at some height. A No. 6 shot happened to touch a wing, the bird immediately lowered, and dropped about a quarter of a mile off. It was pursued and captured."

\section{Genus TADORNÄ, Fleming.}

\section{SHELDRAKE.}

Tadorna tadorna (Linnæus). S.N., i., p. 195

(1766).

Bargander.

This beautiful Sheldrake is a constant visitor to the sea-coast and estuaries of Kent during the winter.

Boys includes it in his Birds of Sandwich, 1792, under Shieldrake or Bargander. The Rev. J. Pemberton 
Bartlett, in 1844, gives this bird the name of Tadorna belloni, and states that it "has been seen in Romney Marsh." It has been seen and obtained by Mr. WV. Oxenden Hammond at Wingham, the Rev. B. Austen at Walmer, Dr. F. Plomley in Romney Marsh, and Mr. IV. Prentis at Rainham.

The following specimens are in the Maidstone Museum: A male obtained by Mr. J. Parker in Romney Marsh, about 1873-4; a female shot at Sheerness, January 27, 1887, by Mr. IV. Cox; a female shot by Mr. H. Payne at Gillingham, November 3, 1893; and a male shot by him on February 15, 1894, at the same place.

Mr. T. Hepburn, in his Birds of North Kent, 1904, states that " in the winter months there are generally large mobs of Ducks to be seen on the Thames. For the greater part they consist of the IVild Duck (Anas boscas), but I have also distinguished at various times the Common Sheld-Duck (Tadorna comuta), the Pintail (Dafila acuta), the Teal (Querquedula crecca), the TVigeon (Mareca penelope), and occasionally the Common Scoter (Edemia nigra) and the Scaup (Fuligula marila); and on one occasion (February, 1904) I saw a small mob of TVild Geese flying over from the Thames in the direction of the Medway, but at too great a distance for me to be able to distinguish the species. The Duclis are liept contimually on the move by passing craft, and are in consequence wild and shy, and not easy to get near; but, concealed by the sea-wall, I had the good fortune to watch for some time (February, 1904) a large flock of fully 200 Sheld-Duck, with a small flock on the landward side of them of about thirty Pintails. They all floated past within a distance of 30 yards (it was high tide at the time) across a small inlet which rejoices in the name 
of Egypt Bay. The Sheld-Ducks were rather noisy, continually uttering a cackling note. One of them noticed my head over the bank, and instantly gave the alarm, with the result that all the mob were soon on the wing, flying out towards the middle of the river."

In Hasted's History of tient (vol. vi., p. 44, 1798) it is stated that in "the Isle of Sheppey, the Bargander or Chenalopex is frequently observed in it."

\section{RUDDY SHELDRAKE.}

Tadorna casarca (Limnæus). S.N., iii., App., p. 224 (1768).

This species is a rare visitor to the county, and only one record of its occurrence of late years is given by the Rev. Thomas Parkins (The Vicarage, Halton, Hastings), in the Zoologist, 1884, p. 469: "A Ruddy Sheldralie was killed on September 8 (1884), by Mr. John Southerden, at the Nidripps in Romney Marsh, Kent, about 12 miles from Rye. It was brought, for preservation, to Mr. Bristowe, naturalist, of St. Leonards-on-Sea. I have seen the bird. Bristowe informed me that it was a male, but the black band round the neck is entirely absent, and it has the head of a light buff, which all point to its being a female." 
Genus MARECA, Stephens.

WIGEON.

Laveca penelope (Linnæus). S.N., i., p. 202 (1766).

Pandle.

During the winter the Wigeon is to be found along the sea-coast and estuaries of Kent, especially in very severe weather, but there are rery few good feeding grounds for this bird on this coast, compared with those on the West of England, where the Wigeon is found in large numbers. They are sometimes found on the inland lakes.

Boys adds this species to the Birds of Sandwich, 1792. The Rev. J. Pemberton Bartlett, in 1844, says it is "common in Romney Marsh."

Mr. J. Gould, writing in 1873, says: "That some Wigeons arrive on the south coast of England from their northern breeding quarters as early as the month of September I can affirm, since, while on a visit to A. J. B. Beresford Hope, Esq., at Bedgebury Park, Kent, the lieeper brought in, on the 28th of that month, as nondescript birds, two which he had just shot, and which proved to be young Wigeon of the year."

A specimen in the Maidstone Museum was shot by Mr. H. Kemnard, at Linton, February 13, 1889. Mr. G. Dowker records it in the Stourmouth district. 
Genus DAFILA, Stephens. PINTAIL.

Dafila acuta (Limneus). S.N., i., p. 202 (1766.)

Boys, in 1792, includes the Pintail among the Birds of Sandwich. There is an adult male in the British Museum which was obtained in Kent, from Colonel Montagu's collection. The Rev. J. Pemberton Bartlett, in 1844, states that it "has been seen in Romney Marsh." Dr. F. Plomley also obtained it in this locality. Mr. A. Skinner, writing to the Zoologist, 1869, says: "A beautiful specimen of this rare bird was shot about 5 miles from Faversham, on January 15 ; it came alone from the sea to some 'saltings.'"

According to the Rev. C. H. Fielding it was found at Cobham, in Kent, in 1881. Mr. W. Oxenden Hammond procured it at Wingham. There is a male and a female in the Maidstone Mruseum, obtained in Kent, from Mr. G. Simmons' collection. Mr. G. Dowker also includes it among the birds of the Stourmouth district. Mr. W. Prentis says it "is much more common in the Rainham Marshes and on the Medway." A solitary female Pintail was seen on a pool of water in a wood at Ruckinge on April 7, 1906. On May 17 this bird was found in a boggy place in another wood not far off. On March 28, 1907, a female Pintail was found on the same pool as above mentioned, and presumed to be the same bird. 
Genus ANAS, Brisson.

WIIAD DUCK.

Anas boscas, Linnæus. S.N., i., p. 205 (1766).

Nallard.

The TVild Duck is resident in Rent and breeds in the most suitable localities, but during the winter large numbers are added to those which are habitual residents. The name Nallard appears to be the most common name by which the Vild Duck is known in Kent. Boys, in 1792, includes the Mallard in the Birds of Sandwich. The Rev. J. Pemberton Bartlett, in 184t, says it "has been seen in Romney Marsh." There is a male, female and young in the British Museum, from East Sutton Park, Kent, obtained in July by W. Berry, Esq.

Mr. W. H. Power, in his Birds Observed at Rainham, says: "A few made their appearance early in September, 1865 , but soon left the neighbourhood." A specimen in the Maidstone Museum was obtained by Mr. R. J. Balston, in Romney Marsh, January 3, 1885. Captain J. D. Cameron includes it among the birds of Bethersden. Mr. R. T. Filmer states that it is common in the Orlestone district. In his Birds of East Kent Mr. G. Dowker says: "The Mallard generally breed in our marshes, and I have known many specimens that were hybrids with the common domestic duck. A curions small white Nallard was shot here (Stourmonth) last winter (1888). A Mallard constructed her nest on the top of a haystack near here; a curious place to choose. I have known them also built in arable fields some distance from water." In the Zoologist, 1891, Mr. W. Prentis relates the following instance of a Wild Duck removing her 
eggs: "A mowing machine was set to work round the outside of a field of lucerne bordering our marsh, diminishing the circle each time round the field, leaving about two acres in the centre. A Wild Duck was seen by the shepherd to fly from the piece of lucerne that was left with something in her beak, and happening to fly near him, she dropped a three-parts incubated egg. She was again observed by the shepherd, and also by the sheep-shearer, carrying another egg in her beak, this time over the marsh wall towards the saltings; and again she was seen for the third time carrying an egg in her beak in the same direction. On the mowing machine going to work next day, and finishing the field by removing the last piece of lucerne, the Wild Duck's nest was discovered from which the eggs had been removed."

A Wild Duck had a nest of fifteen eggs in September, 1898, in Surrenden Dering Park, Kent. These birds were seen in Long Rope Woods on March 13, 1902.

$\mathrm{Mr}$. T. Hepburn, in his notes on the birds on the beach at Dungeness, in 1902, states that this species " breeds in numbers along the dykes and sewers, and also out on the beach among the stunted sloe and broom bushes. July 16 to 21 : Considerable numbers of young birds on some of the inland patches of water."

Note.-Wild Duck.-In Hasted's History of Kent (vol. vi., p. 167, 1798), under Milton, near Sittingbourne, is the following: "In the north-west part of this parish, among the marshes, there is a decoy for wild-fowl, the only one that I know of in this part of the county. The fowl caught in it are much esteemed for their size and flavour. Great numbers of them are weekly taken and sent up to London." 
Genus Chaulelasmus, G. R. Gray.

\section{GADIVALL.}

Chanlelasmus streperus (Linnæus). S.N., i., p. 200 (1766).

The Gadwall is a very rare accidental visitor to Kient, or maybe it is overlooked among the female Wild Ducks. Boys adds it to his Birds of Sandwich, 1792.

There is a specimen, an adult male, in the British Museum, labelled Kient, from Colonel Montagu's collection. The Rev. J. Pemberton Bartlett, writing in the Zoologist, 1845, p. 1025, says: "A male specimen of the Gadwall was shot in Romney Marsh on February 22, 1845. As far as I am able to discover, I believe this is the first specimen obtained in Kent."

There is a Kentish specimen in the Canterbury Museum.

\section{Genus QUERQUEDULA, Stephens.}

\section{GARGANEY.}

\section{Querquedula circia (Linnæus). S.N., i., p. 204 (1766).}

The Garganey is more often found in Kent than the last-named species, but it is far from being numerous. There is one record of its having bred in the county.

Boys includes it in his Birds of Sandwich, 1792. The Rev. J. Pemberton Bartlett, in 1844, says it is " not common: Dr. F. Plomley has obtained four specimens in Romney Marsh." Mr. G. F. Nathew, writing on May 12, 1870, says: "A friend of mine shot a fine pair 
of Garganeys, about the middle of March, 1870, near Sheerness."

In the Zoologist, 1900, Dr. N. F. Ticehurst relates a long account of the breeding of the Garganey in Kent. He says: "I have the pleasure of recording, I believe for the first time, the breeding of the Garganey in Kent. My brother found the nest on May 2, in Romney Marsh. It was situated in quite a dry place in some long grass, and between 30 to 40 yards from the nearest water. When first seen the nest consisted of only a ferw strands of dead grass, and contained one egg. On May 3 there were two eggs, and a lot more of grass strands had been added to the nest, which was so well covered up and hidden that we had some difficulty in finding it agaiu. On May 7 the nest contained six egogs, which were sparsely covered with down and a few grass stems, the nest itself, owing to its increasing size, being much more easily seen than before. Subsequently, on May 12, we found a second nest containing five eggs and the remains of a sixth, which had been broken, probably by being trodden upon by a sheep. The nest was deserted, the remaining eggs being glued to the nest by the contents of the sixth, the spaces between the eggs being occupied by a small growth of mildew. The amount of down in this nest was much less than that in the first, but still there was quite enough to surely identify the eggs by, the down being quite characteristic, and wholly unlike that of the Common Teal. I have suspected that this bird bred in Romney Marsh for some years, ever since having been told by a former resident there that a pair or two of Garganey generally turned up at a certain spot about May 1 every year, but that so far as he knew they did not breed." 
A pair of these birds, obtained in Narch at Shoreham, Kent, from Mr. H. Seebohm's collection, are in the British Museum.

Mr. W. Prentis records " a pair of Garganey that were shot on one of the island marshes at Rainham on March 7,1874 , and three immature birds were shot on one of the creeks, August, 1893.'”

It is also noticed by Mr. WV. Oxenden Hammond at Wingham, the Rev. B. Austen at Walmer, and Mr. H. Ullyett at Folkestone.

\section{TEAL.}

Querquedula crecca (Limnius). S.N., i., p. 204 (1766).

This handsome little Duck is a resident species in Kent, and breeds in most of the wooded districts. After rearing their brood they wander over the country to the most suitable feeding grounds, returning to their nesting lawnts in the spring.

Boys records it in his Birds of Sandwich, 1792. The Rev. J. Pemberton Bartlett, in 1844, says it is " common in Romney Marsh."

Mr. WV. H. Power, in his Birds Observed at Rainham, 1865, states: "I saw a large flock of Teal on September' 15; a few days later my brother killed a single bird that rose out of one of the creeks. As a rule, very few ducks are seen before hard weather sets in." Captain J. D. Cameron adds it to the birds of Bethersden. MIr. G. Dowker says it is common in the Stourmouth district.

It occasionally breeds in the woods at Orlestone. On March 13, 1902, three were seen, and others have been 
obtained since. A pair bred in a boggy wood called Birchett, in 1905 and 1906. Some nests were generally to be found in other large woods in the neighbourhood.

\section{Genus SPATULA, Boie.}

\section{SHOVELLER.}

Spatula clypeata (Linnæus). S.N., i., p. 200 (1766).

The majority of Shovellers are only winter visitors to Kent, keeping to the sea-coast and estuaries, but a few remain to breed.

Boys includes it in his Birds of Sandwich, 1792. The Rev. J. Pemberton Bartlett, in 1844, states that it is "common in Romney Marsh." Of late years it may be looked upon as a rare bird. It was obtained at Fordwich by Mr. W. Kennet. It is now rare according to MIr. G. Dowker in the Stourmonth district. It visits the Rainham Marshes, according to Mr. WV. Prentis. The Rev. C. H. Fielding states that it was found at Cobham in 1881, and at Boughton Monchelsea in 1885.

There are two specimens, a male, an immature bird, taken by Mr. H. Payne on August 1, 1893, at Gillingham, and a female at the same place and date, in the Maidstone Museum.

Dr. N. F. Ticehurst, in the Zoologist, 1900, says: "On May 3 last (1900) I put up a pair of Shovellers from a piece of water in Romney Marsh; I got a good view of these through my glasses, and saw them a second time about half an hour later, when they flew back over my head. I searched the neighbouring rush, tufts, sc., but was unable to find any nest. On going back, however, 
to the same place on May 19, I saw the duck swimming, followed by nine young ones a day or two old. The drake was not visible on this occasion. So far as I am aware, this is the first record of the Shoveller breeding in Kent."

In the spring of 1906 a Shoveller's nest was found at Orlestone, containing twelve eggs.

\section{Genus FULIGULA, Stephens. RED-CRESTED DUCK.}

Fuligula rufina (Pallas). Reise, ii., App., p. 713, No. 28 (1773).

In 1853 a flock of eighteen Red-crested Ducks made their appearance near Erith, and one, a female, was shot on the estate of the Hon. W. T. T. Fiennes, and was in his collection. This female was figured in Mr. J. Gould's Birds of Europe.

\section{TUFTED DUCK.}

Fuligula fuligula (Limnæus). S.N., i., p. 207 (1766).

The Tufted Duck is a winter visitor to the sea-coast and estuaries of Kent.

Boys adds it to the Birds of Sandwich, 1792. Mr. IV. Oxenden Hammond obtained it at Wingham; the Rev. B. Austen at Valmer; Mr. G. Dowker at Stourmouth in 1874-82-89. Mr. W. Prentis says "The Tufted Duck is not uncommon in the creeks and marshes at Rainham in the winter." 
There is an immature male in the Maidstone Museum, shot by Mr. H. Payne at Sheerness, February 14, 1889. Mr. R. J. Balston shot one in the park at Clare House, Malling, about 1879.

\section{SCAUP.}

Fuligula marila (Linnæus). S.N., i., p. 196 (1776).

A winter visitor to the sea-coast and estuaries of Kent, but not an abundant species like some of the other ducks.

Boys includes it in the Birds of Sandwich, 1792, and the Rev. J. Pemberton Bartlett, in 1844, states that it is common in Romney Marsh; Mr. C. Gordon at Dover; Dr. F. Plomley in Romney Marsh; Mr. H. Ullyett at Folkestone. Mr. G. Dowker obtained it in the Stourmouth district in 1885 .

An immature male was obtained by Mr. H. Kennard, at East Farleigh, Kent, January 29, 1879, and Mr. H. Payne shot a female at Sheerness, December 31, 1890, and a male at Gillingham, January 13, 1894. These three birds are in the Maidstone Museum.

\section{POCHARD.}

Fuligula ferina (Linnæus). S.N., i., p. 203 (1766).

Dun-Bird.

The Pochard is another winter visitor to the sea-coast and estuaries, and at times it finds its way to some of the larger inland lakes and ponds in Kent.

Boys adds the Pochard, or Dun-Bird, to the Birds of Sandwich, 1792. The Rev. J. Pemberton Bartlett, in 1844, says it is "common in Romney Marsh." Lord Clifton, writing from Cobham Hall, Kent, January 24, 1867, says : 
"Three Pochards, two drakes and a duck, made their appearance lately on a fish-pond here, where the pearly whiteness of their plumage excited much admiration. They disappeared at the approach of frost. The curious thing was that they never took to flight, but swam about in the middle of the pond." A male, labelled "Kent," is in the British Aruseum. It has been obtained by Mr. W. Oxenden Hammond at Wingham; Mr. C. Gordon at Dover; Dr. F. Plomley in Romney Marsh. A male in the Maidstone Museum was shot by Mr. M. W. Martin, on the moat at Leeds Castle, Kent, January 20, 1885.

\section{Genus NYROCA, Fleming.}

WHITE-EYED DUCK.

Nyroca ferruginea (Gmelin). S.N., i., p. 528 (1788).

Morris, in his History of British Birds, records, on the authority of Mr. Chaffey, that a White-eyed Duck was killed off the coast near Dover during the winter of 1849-50.

\section{Genus CLANgULA, Boie.}

GOLDENEYE.

Clangula glaucion (Linnæus). S.N., i., p. 201 (1766).

Morillon Duck, Boys, 1792.

The Goldeneye is only a winter visitor to the coast of Kent.

The Rev. J. Pemberton Bartlett, in 1844, says: "The females are common in Romney Marsh, but the males. 
are rare." This must refer to Goldeneyes which were in the winter plumage and young males. Morris records an immature bird that was shot at Swanscombe, in Kent, in 1847. The following specimens are in the Maidstone Museum: A female, shot by Mr. J. Covenay, at Hollingbourne, January, 1881 ; a male, by Mr. H. Kennard, at Linton, January 18, 1888 ; a female, by Mr. H. Payne, at Sheerness, December 20, 1890; a female, by the Rev. H. W. Trower, at Boxley, January 20, 1891.

It has also been procured by Mr. G. Dowker at Stourmouth in 1886-89; Mr. W. Oxenden Hammond at Wingham; Mr. C. Gordon at Dover; Mr. H. Ullyett at Folkestone; Dr. F. Plomley in Romney Marsh.

Mr. H. Elgar, writing on January 25, 1907, says: "Mr. E. Hills came in yesterday to tell me of the occurrence of a Goldeneye on the Len, at the bottom of his garden, in the Ashford Road, Maidstone."

Genus HARELDA, Stephens.

\section{LONG-TAILED DUCK.}

Harelda glacialis (Linnæus). S.N., i., p. 203 (1766).

This is a rare winter visitor to the coast of Kent, and then only in very severe weather.

The Rev. J. Pemberton Bartlett, in 1844, states that "there are two specimens of this duck in Dr. F. Plomley's collection." Mr. W. Oxenden Hammond obtained it at Rye. There is a pair of Kentish specimens in the Maidstone Museum from Mr. G. Simmons' collection. Mr. G. Dowker states that "the Long-tailed Duck is very rare indeed as a Kent bird." 


\section{Genus SOMATERIA, Boie.}

\section{EIDER DUCK.}

Somateria mollissima (Linnæus). S.N., i., p. 198 (1766).

The Eider Duck may be considered as an accidental visitor to the coast of Fent in very severe weather.

Boys includes it in the Birds of Sandwich, 1792, under the name of "Eider Goose." There is a female obtained in Kent in the Maidstone Museum, from Mr. G. Simmons' collection, and Mr. G. Dowker says " an Eider Duck in the Canterbury Museum was, I believe, from the neighbourhood."

\section{KING DUCK.}

Sonateria spectabilis (Linnæus). S.N., i., p. 195 (1766).

Mr. Oliver V. Aplin, in the Zoologist, 1886, p. 335, writes: "In the University Mnseum at Oxford there are examples of two rare British birds, of which I can find no mention in the Handbook of British Birds, or the last edition of Yarrell's British Birds, it may, therefore, be worth while to place them on record in the pages of the Zoologist. An adult male King Duck is labelled 'Erith Reach, Kent. Presented by Lord Saye and Sele.' This specimen formed part of a collection of British birds bequeathed by the late Lord Saye and Sele to the Ashmolean Museum in 1847, and was labelled in that collection 'Shot in Erith Reaches, Kent.', 


\section{Genus EDEMIA, Fleming.}

\section{BLACK SCOTER.}

Edemia nigra (Limnæus). S.N., i., p. 196 (1766).

This Scoter is more or less numerons on the coast and in the estuaries of Kent during winter.

Boys adds it to the Birds of Sandwich, 1792. The Rev. J. Pemberton Bartlett, in 1844, says it is " common in Romney Marsh." There is a young bird in the British Iuseum, obtained at Hythe, by H. J. Elmes, Esq. The Rev. B. Austen notes it at Walmer; MIr. G. Dowker at Stourmouth. Mr. J. Gould, in the Birds of Great Britain, states: "In the winter season we can scarcely take a trip from Dover to Calais, or from Folkestone to Boulogne, without the vessel stearning through little lnots of the Scoter; while from the deck strings of forty or more may frequently be seen passing to and fro from one part of their feeding grounds to another. Mr. Dann has seen flocks off Dungeness as late as the middle of June."

In the Maidstone Museum there is a male obtained at Lydd, January 17, 1883, by Mr. H. Kennard, also a specimen that was shot on the Medway as high up as Tovil, which is above Maidstone; another, a female, from Gillingham, Kent, October 4, 1894, by Mr. H. Payne; and three males and two females procured on the lower Medway by Mr. R. J. Balston.

Mr. J. H. Gurney, writing in the Zoologist, 1894, says : "My remarks on the partial assumption by female birds of male plumage (Zoologist, 1894, p. 15) has elicited from the Rev. H. A. Macpherson a very interesting correspondence, in which he mentions a female Scotor, Edemia 
nigra, shot and dissected by Mr. E. Bartlett, of Maidstone, in which the brown plumage of the upper parts was replaced by black."

\section{VELVET SCOTER.}

Eclemia fusca (Limmæus). S.N., i., p. 196 (1766).

The Velvet Scoter is an occasional winter visitor to the coast of Kent.

Boys places this bird under the name of Velvet Duck in his Birds of Sanduich, 1792. There is a young male in the Maidstone Museum, obtained on the Lower Medway, October 11, 1887, by Mr. R. J. Balston. Mr. IV. Oxenden Hammond procured it at Wingham; Mr. C. Gordon at Dover; Dr. F. Plomley in Rommey Marsh; Mr. H. Ullyett at Folkestone; Mr. G. Dowker at Stourmouth, 1888.

The Rev. C. H. Fielding mentions "a stuffed specimen which belonged to a countryman, who captured it when it entered a farmyard at Frindsbury, Kent, to feed."

\section{Genus MERGUS, Limnieus.} GOOSANDER.

Mergus merganser, Limmæus. S.N., i., p. 208 (1766). Dun Diver.

This bird is frequently observed and obtained along the coast and in the estuaries of Kent, but only as a winter visitor.

Boys adds this bird, under the name of "Dun Diver," to the Birds of Sandwich, 1792.

There is a specimen in the Canterbury Museum, obtained on the River Stour by Mr. W. Oxenden 
Hammond. Mr. C. Gordon procured it at Dover; the Rev. WV. B. Delmar at Elmstone; Mr. H. Ullyett at Folkestone; Dr. F. Plomley in Romney Marsh, and Mr. G. Dowlier at Stourmouth, 1884.

There is a male Goosander in the Maidstone Museum, obtained in Romney Marsh on December 5, 1881, by Mr. R. J. Balston.

\section{RED-BREASTED NERGANSER.}

Mergus serrator, Linnæus. S.N., i., p. 208 ( 1766).

A frequent winter visitor to the coast and estuaries of Kent, and there are many records of it having been obtained in various localities.

Boys includes it in the Birds of Sandwich, 1792. The Rev. J. Pemberton Bartlett, in 1844, states that it is "common."

In the Zoologist, 1870, p. 2182, MIr. G. F. Nathew says: "A friend of mine shot a magnificent pair of Hooded Mergansers, the male of the latter species being in splendid plumage." This remained uncorrected until 1876, when Mr. G. F. Nathew wrote to the Zoologist, May 9, 1876 (p. 4958) as follows: "I must apologise to Mr. J. H. Gurney for having left his question concerning the occurrence of this species (the Hooded Merganser) at Sheerness in March, 1870, so long unanswered. The birds in question were merely the common Red-breasted Merganser, the male being in fine breeding plumage. I am sorry such a mistake should have occurred, and can only attribute it to a slip of the pen, for I never noticed the error myself, and am much obliged for attention having been called to it." This correction was overlooked by the Editor of the last edition of Yarrell's British Birds. 
There is a male in the Maidstone Museum, obtained at Herne Bay, 187.2, by Mr. E. Bartlett, and a female obtained at Sheerness, February 14, 1889, by Mr. H. Payme.

It has been procured by Dr. F. Plomley in Romney Marsh; Mr. C. Gordon at Dorer; the Rev. B. Austen at Walmer; Mr. H. Ullyett at Folkestome, and Mr. G. Dowker at Stourmouth in 1886.

A male in the Maidstone Museum was shot in the Medway on February 25, 1881, by Mr. R. J. Balston.

\section{SIIEW}

Mergus albellus, Limmæus. S.N., i., p. 209 (1766). Magpie Diver; Minute Goose.

Boys, in his Birds of Sanduich, 1792, calls this bird the Minute Goose. It is only an occasional winter visitor to the coast of Kent.

There is a pair in the Maidstone MIuseum from Mr. G. Simmons' collection; others have been recorded by Mr. C. Gordon at Dover; Mr. H. Ullyett at Folkestone; Mr. G. Dowlier at Stourmouth in 1885, and Dr. F. Plomley in Kent.

\section{Family COLUMBIDE. Genus COLUMBA, Linnæus. RING-DOTE.}

Columba palumbus, Linnæus. S.N., i., p. 282 (1766).

\section{Trood-Pigeon.}

This fine large Wood-Pigeon, so easily recognised, is one of the most abundant species of pigeons in every 
district throughout the county. It would be difficult to wander through the extensive woods and Pheasant preserves in Kent without disturbing many pairs of these birds, which dash out from the trees and undergrowth and startle one. At times many may be seen on the ploughed land and open pastures seeking food.

'Their large, loosely constructed nests of sticks and woodbine are conspicuous objects, and attract attention the moment the bird darts off at full speed.

Dr. A. G. Butler mentions having found a nest in some ivy, with three young ones, while in company with Mr. Janson. This is, no doubt, a rare occurrence, for it is well known to all naturalists that two eggs are the complete clutch.

The voice of this bird has been variously described, but it sounds like-cōo cōo cōò cŏo cŏo uttered three times, then cŏol:

Mr. IV. H. Power, in his Birds Observed at Rainham, states: "In May, 1863, I took a Ring-Dove's nest out of a hollow cherry tree in an orchard within a few hundred yards of the marshes."

The Ring-Dove, or Wood-Pigeon, is very common about Boxley, frequenting the large woods in winter, and also the yew trees on the Boxley hills, where it breeds. It is common on the Dering estate at Pluckley, and at Orlestone, where one was shot weighing $1 \mathrm{lb}$. 6 ozs. on January 30, 1902. A pair were seen at Springfield, Maidstone, in an elm, apparently eating the buds, March 3, 1902. This species consumes a tremendous quantity of vegetable food of many kinds, and is very destructive to peas and cereals. 


\section{S'TOCK-DOVE.}

Columba cenas, Linnæus (partim). S.N., i., p. 279 (1766).

Although this bird is to be met with occasionally in pairs in most of the large woods throughout the county, It is far from being a common species. It still breeds in suitable places in the larger and more secluded woods and plantations.

Mr. W. H. Power, in his Birds Observed at Rainham, says: "Early in July of this year (1865) I constantly saw small flocks of these pigeons on the marshes, but, owing to their exceeding wariness, could never get within range; at length one day I stalked some and killed three, one of them a young bird about two-thirds grown. This is, I think, presumptive that the StockDove breeds in the Kentish woods, where, although they were formerly to be constantly found in the autumn, they have, within the last twenty years, become decidedly uncommon." Lord Clifton, in 1866, stated that the Stock-Dove was "very common in the woods at Cobham, and builds both in trees and rabbitholes."

Mr. 'T'. Hepburn records, in his notes on the birds at Dungeness, that "always a few of these birds are about the beach feeding on the green places. Nay 14, 1900: I noticed one of these birds fly up from a rabbit's burrow. Upon investigating I found its rough nest and two young birds down the burrow."

MIr. R. T'. Filmer says it is "rare in the Orlestone district. A nest was built and young ones raised for several years in an old, tumble-down lodge in Bourne Wood, Kent." 
On May 8, 1906, a pair of Stock-Doves were seen in the woods between Ruclinge and Bilsington, where they remained during the early part of the summer, but their nest was not discovered. This species had a nest in old wall in the Boxley Abbey meadows in 1877 and 1878. Its note in autumn and winter is cōo, cōo, in single syllables, and many times repeated.

\section{ROCK-DOVE.}

Columba livia, Bonnaterre. Encl. Méth., i., p. 227 (1790).

The Rock-Dove is seldom seen in Kent. It is supposed that they used to breed in the higher cliffs between Dover and St. Margaret's Bay, but the Peregrine no doubt put a stop to their existence in that locality. Mr. H. S. D. Byron met with this bird in the marshes of St. Peter's, Thanet.

\section{Genus TURTUR, Selby.}

\section{TUR'TLE-DOVE.}

Turtur turtur (Limneus). S.N., i., p. 284 (1766).

This beautiful Dove arrives early in Nay in large numbers, and they are soon distributed throughout the wooded districts of Kient, where they may be heard in all directions, breeding freely in every wood and plantation.

Their slightly constructed nests of a few twigs, held together by a few small lengths of woodbine, are so 
openly made as to allow the observer to see the eggs lying on the little platform of twigs, 7 or 8 feet from the ground. Its artival has been noticed on May 1, 1872, and May 2, 1902, in Kent.

The note is cōo cōo cŭo cơo. Great numbers of these birds frequent Snodland Marshes, no doubt for the purpose of drinking the brackish water in hot weather. Varieties of the Turtle-Dove are often met with, and Lord Clifton mentions a white one found at Cobham Hall, Kent.

\section{Family PTEROCLIDÆ.}

Genus SYRRHAPTES, Illiger.

\section{PALLAS'S SAND-GROUSE.}

Syrrhaptes paradoxus (Pallas). Reise Russ. Reichs.,

$$
\text { ii., App., p. } 712 \text { (1773). }
$$

The records of the occurrences of Pallas's Sand-Grouse in Kent are here subjoined, with the particular's connected with their capture. The first notice is that contained in Yarrell's British Birds, 1882-84: "In November, 1859, Mr. George Jell, of Lydd, in Kent, preserved a specimen for Mr. Simmons, of East Peckham, near Tunbridge." Perhaps this is the specimen which is in the Maidstone Nuseum, presented by Mr. G. Simmons. In the Zoologist, 1863, p. 8721, Mr. E. Young, of Sittingbourne, Kent, writing on July 1, 1863, says: "I have two specimens of this rare bird (male and female), shot on June 7, 1863, at Elmley, Sheppey, from a covey of six, and to my knowledge four have been shot out of that number." The two above-mentioned specimens are 
in the collection of Mr. WV. Prentis, who also states that "the year 1888 was the second Sand-Grouse year, four were seen upon a ploughed field for several days in the parish of Hoo, near Rochester. On December 14 a male was picked up dead, with the head cut clean off by the telegraph wires, on the Isle of Grain railway; another, I believe, was shot about the same time near Sheerness."

There is a specimen in Mr. WV. Oxenden Hammond's collection, now in the Canterbury Museum, obtained in Kent in 1888, without exact locality attached.

In the Zoologist, 1888, p. 264, Mr. J. E. Harting adds the following note from Mr. H. S. D. Byron, of Bromstone Farm, St. Peter's, Thanet: " IVill you kindly allow me to place on record in the Zoologist what I have not the least doubt was an occurrence of Pallas's Sand-Grouse in this neighbourhood (St. Peter's, Thanet). A bird was first seen on May 30, and was then feeding on a field of recently sown spring tares. What first attracted my attention to it was that it did not rise and fly away when I entered the field, as was done by several wild RockDoves, which were feeding near it. However, it would not allow a very near approach, but ran with considerable speed over the ground with its body close down, and looking almost like a sinall animal. When at last I made it fly, by a dog I had with me, it went at a very rapid pace, and looked much like a Golden Plover, only larger, uttering, as it flew, a low piping note. On the morning of the following day (May 31), this bird again made its appearance in the same field, but all attempts to get near it were futile. I must not omit to say that the colour, as seen from a distance, was light greyish-brown." 


\section{Family PHASIANIDE. Genus PHASIANUS, Linneus.}

PHEASANT.

Phasianus colchicus, Linnieus. S.N., i., p. 271 (1766).

The early history of the introduction of the Pheasant still remains uncertain, but from all that can be gathered it is clear that it was before the Norman conquest. It is highly probable that it came with the Romans, who brought all their luxuries with them, and who remained, and made their homes in Kent, for a considerable period before advancing north; therefore it is not difficult to suppose that Kent is the real birthplace of the Pheasant, and from this county it has gradually spread on all sides and gone or been taken north. It is well known that the bird is not a northern species, even in Europe.

Mr. W. B. Tegetmeier, in his work on Pheasants, says: "The Pheasant, though introduced by, or anterior to, the Romans, is still by some Britons cherished almost as a visible sign of a British institution."

Writing in the Zoologist, 1856, Mr. William Thomson says: "I have received from Mr. King, of Canterbury, an ivy-leaf (which I enclose) taken with many others from the stomach of a hen Pheasant on January 18, 1856. They were not all perfect, many being digested. The crop was quite full of them, and the bird smelled and tasted of ivy, although to all appearance in good condition and quite healthy. There was no snow on the ground, so the bird was not pressed for food, there being plenty of wild blue periwinkle and ground-ivy leaves to be had. None of the leares appear to have been eaten by insects. The bird was shot off a tree by the keeper, who in the 
dusk mistook it for a Wood-Pigeon. My friend, who has been a sportsman since 1818, and who is a careful observer, never remembers a similar instance of Pheasants feeding on ivy."

By the care and attention of the keepers the woods and plantations throughout Kent are generally well stocked with Pheasants, but the majority of them have a tinge of the ring-necked birds, which it is desirable, if possible, to stamp out.

Mr. D. G. Elliot, in his great work on Pheasants, 1874, writes: "Every preserve in England and on the Continent inhabited at all by Pheasants contains this bird, but it is difficult to meet with one which has not at some time or another received an infusion of foreign blood, and consequently presents evidence in its plumage of its ancestors having lived in the vicinity of $P$. torquatus and $P$. versicolor, which species have also been largely introduced into Europe. It is a matter of regret that this hybridisation should be permitted, for it in no way improves any of the species, and gives to us a race of mongrels which, at least to an ornithologist's eye, is anything but agreeable."

There is no doubt that the Ring-necked Pheasant has been the cause of the deterioration in the size, weight and beauty of the old English Black-necked Pheasant.

\section{Genus CACCABIS, Kaup. RED-LEGGED PARTRIDGE.} Caccabis rufa (Linnæus). S.N., i., p. 276 (1766).

French Partridge.

This introduced species has now become established and breeds freely throughout the county, and is evidently 
a great trouble to all true sportsmen, and is inferior in every respect, although a trifle heavier, than our own Partridge. It is doubtful whether the numbers are increased in Kent by others from the Continent, but there is no reason why a bird of such powerful flight should not do so, especially when we know that the Quail comes.

Mr. G. Dowker, in his Birds of East Kent, writes: "The Red-legged Partridge has very much increased in East Tent of late; it is detested by the sportsman, as it lieeps running, seldom getting up within shot, spoiling the dogs' and the sportsman's temper. I can remember the time when it was never met with in this (Stoumouth) or the adjoining parishes. It goes also by the name of the French Partridge, and the notion that it occasionally crosses over from France is strengthened from the following circumstance. On November 13, 1884, Gisby (an old boatman and sportsman of Ramsgate) informed my friend, the late Mr. Hillier, that he (Gisby), while out in his boat, saw twenty-two Partridges which flew so near him that he could see they were red-legged, coming over the water from the French coast, and seemed very tired. I also remember meeting a number of these birds about this neighbourhood, where they had not been known or seen about earlier in the season, this being in October, and they were so tired that they were easily hunted down."

In the Zoologist, 1873, Mr. James Murton states that "On the 1st inst. (August), I was visiting at Smeeth, near Ashford, and in the course of my walks my attention was called to two Partridge nests, in which the young had been hatched this year. I saw at once from the egg-shells that both were the nests of the Red-legged 
Partridge. These two nests were within a hundred yards of each other. A third nest, very near the same spot, was mentioned to me, but I had not time to go and examine it. It appears that this species of Partridge is on the increase in Kent, and being difficult to shoot, will soon abound to the exclusion of the more valued English Partridge."-August 11, 1873.

Mr. T. Hepburn, in his notes on the birds at Dungeness, writes: "May 13, 1900, found a nest of this species built on the bank of one of the big sewers which drain the marsh-land. Also saw several of the birds out on the beach."

\section{Genus PERDIX, Brisson.}

\section{PARTRIDGE.}

Perdix perdix (Linnæus). S.N., i., p. 276 (1766).

The well-known Partridge, especially to all lovers of sport, and for the table, is still abundant throughout the county, breeding in every district, whether preserved or not. With regard to the size and weight of this bird MIr. J. Gould writes: "A. Partridge exceeding a pound in weight is rarely met with, in the whole course of my shooting I never lilled but one, this was at Preston Hall in Kent."

In Yarrell's British Birds it is stated that "dry summers are particularly favourable to the breeding of Partridges." This depends on the soil, as to their living, because on clay soils the young birds are liable to fall into the large cracks in the earth.

Mr. J. W. Hulke, of Deal, in writing to the Zoologist, 1849, on the migration of the Common Partridge, says: "On November 29, 1848, some men in a fishing 
boat of this place (Deal) saw a covey of Partridges coming towards them (as if from France); one, more exhausted than the rest, fell into the boat; the rest reached the shore in safety." Many varieties of the Partridge are obtained during a season, some being pure white, some having white wings, or mottled with white. Lord Clifton mentions a buff-coloured bird obtained at Cobbam, Kent.

On May 15, 1906, a Partridge took to laying eggs in a wooden moveable forl-house, placed in a field in Romney Marsh, and in the same house a wild Rabbit. reared a litter of young ones.

\section{Genus COTURNIX, Bonnaterre.}

QUAIL.

Coturnix coturnix (Linnæus). S.N., i., p. 278 (1766).

The Quail appears to be an irregular visitor to Kent, at the same time it has been found to breed on the more open bills and rough, sandy places in the county.

Boys includes it in the Birds of Sandwich, 1792, and the Rev. J. Pemberton Bartlett, in 1844, says it is. " not common in Kent."

This species was seen by Mr. R. J. Balston at Thurnham, in Kent, on Sir G. Hampson's property, who informed him that a bevy was generally to be found there. Four occurred on Major Best's property at Boxley, two. of which were shot, September, 1871, and one he found in some swedes on Tyland Farm (Lord Aylesford's land), September, 1871. In August, 1873, he used to hear them calling in the evening and supposed they must. 
have bred on Tyland Farm. It has been found at Cobham in Kent. Mr. G. Dowker speaks of the Quail being exceedingly irregular in its visits, and mentions 1863 and 1887, evidently exceptional years for it.

There is a female in the Maidstone Museum, obtained at Hollingbourne in October, 1892, by Colonel Franklyn, and a male obtained at Teston, in Kent, November, 1893, by Colonel Ward.

 Genus LAGOPUS, Brisson.}

RED GROUSE.

Lagopus scoticus (Latham). Ind. Orn., ii., p. 641 (1790).

The Red Grouse being a resident in the north of England and Scotland, seldom or never makes a passage south. Mr. G. Dowler, however, in his Birds of East Kent, records an instance of its occurrence in the county, and states that "Mr. W. Oxenden Hammond shot a specimen of the Red Grouse at Knowlton."

\section{Genus TETRA0, Linnæus.}

\section{BLACK GROUSE.}

Tetrcco tetrix, Linnæus. S.N., i., p. 274 (1766).

The only evidence of a very early existence of the Black Grouse in Kent are the subjoined particulars, culled from the last edition of Yarrell's British Birds, viz.: "Although at the present day the word Grouse, 
when used alone, is applied in common parlance to the Red Grouse (Lagopus scoticus), yet it would appear from Professor Newton's researches that the earliest record of its employment is with reference to the present species." "It first seems to occur (vide O. Salusbury Brereton, Archaologia, iii., p. 157) as 'grows' in an ordinance for the regulation of the royal household dated 'apud Eltham, mens. Jan. 22, Hen. VIII., i.e., 1531, and, considering the locality, must refer to Black Game." "The increase of population, the enclosure of wastes, and the drainage of boggy lands, have combined to curtail the area over which the Blach Grouse formerly roamed in the south of England, and neither Elthamonce a favourite resort of Plantagenet and Tudor sovereigns-nor any other part of Kent can now show any indigenous birds."

\section{Family RALLIDÆ.}

\section{Genus RALLUS, Linnæus.}

\section{WATER-RAIL.}

Rallus aquaticus, Limmeus. S.N., i., p. 262 (1766).

This bird is far from being plentiful in any part of Kent, and it appears from the records to hand that most of the specimens have been obtained in late autumn and winter.

Boys records it among the Birds of Sandwich, 1792. In the Zoologist, 1844, the Rev. J. Pemberton Bartlett writes: "I observe in the Zoologist for this month (Zoologist, 575) a note by Mr. Hussey on the Water- 
Rail, in which he mentions that Mr. Yarrell speaks doubtfully as to whether Water-Rails remain in England during winter. Perhaps you would be good enough to add, under Rallus aquaticus, in my list of Kentish birds (Zoologist, 625), the following confirmation of Mr. Hussey's opinion, that they do remain here all the winter. While walking by a small stream in this neighbourhood (Kingston), in the early part of last December, a retriever which accompanied me caught in an old hedge a small Vater-Rail, which, with considerable satisfaction, she laid at my feet. A few weeks after, near the same spot, she caught the female. I am quite of opinion that these birds are resident here all the winter. In fact, from finding them at different times during the winter, I cannot doubt that some at least remain throughout the year in England."

There is a female in the British Museum which was obtained at Dungeness on November 14, by Colonel Irby. A female obtained on Boxley Hills, in Kient, on November 15, 1884, by Mrr. A. F. Style, is in the Maidstone Museum, also two males obtained at Pluckley, in Kent, December, 1894, by Mr. R. J. Balston. Mr. G. Dowker writes that the "Water-Rails are tolerably abundant, and excellent eating," that is, in the Stourmouth district. Mr. W. Prentis, in his Birds of Rainham, says: "Almost every winter our Marsh ditches and spring water-courses contain a Water-Rail or two." Mr. R. T. Filmer states that the Water-Rail is "rare, usually one can be seen in a walk through Romney Marsh, from Appledore to Rye. One was shot below the Military Canal, in Romney Marsh, on December 11, 1906. Mr. R. J. Balston shot one on Boarley Farm, Boxley, on January 29, 187.2, which proved excellent eating. 


\section{Genus PORZANA, Vieillot.}

\section{SPOTTED CRAKE.}

Porzana porzana (Linnæus). S.N., i., p. 262 (1766).

Morris, in his History of British Birds, states that "Mr. E. Blyth saw one in the London market in January, 1834, which was said to have come from Kent." The Rev. J. Pemberton Bartlett, writing in 1844, says the Spotted Crake is "common in autumn in Romney Marsh."

There is a specimen in the Maidstone Museum, obtained at Hythe, in Kent, by Mr. J. R. Price.

In the Zoologist, 1891, Mr. O. V. Aplin contributed an article on The Distribution in the British Islands of the Spotted Crake, from which is subjoined a note under Fent: "In reply to my request for information (Zoologist, 1870, p. 457), Mr. W. Oxenden Hammond, of St. Alban's Court, near Wingham, has been good enough to send me the following note: 'I can give none with reference to its breeding in this neighbourhood, although in the wet summer of 1880 (I think that was the year), I remember lilling one in the flooded marshes at Stodmarsh, near Canterbury, in July, the marshes being full of Snipe. From the season, this bird had probably bred. I have killed several, at different times, in the marshes at Wingham. It is rather a curious coincidence that, having read your article on this bird in the Zoologist in the evening, I went to shoot Snipe the next morning (November 1), and in the course of the day killed a Spotted Crake.'" The specimen now in the Canterbury Museum, labelled Wingham, no doubt is the bird mentioned above. MIr. W. Prentis states that " our Rainham 
marsh is not always without a Spotted-Rail; when they appear it is in the autumn, generally in the month of October."

\section{BAILLON'S CRAKE.}

Porzana bailloni (Vieillot). Nouv. Dict. d'Hist. Nat., xxviii., p. 548 (1819).

Baillon's Crake is a rare visitor to Kent, and few instances of its occurrence are recorded. The earliest notice is that which is given by Mrr. C. A. Delmar in the Zoologist, 1850, who writes: "On September 19, 1850, I obtained a beautiful specimen of Baillon's Crake in the marshes near Deal, in Kent." Mr. J. W. Hulke, of Deal, January 15, 1851, states: "In the latter part of October last (1850), my friend, Mr. C. A. Delmar, obtained a second specimen of Baillon's Crake, not far from the spot where he procured one in the September previous. It is now in my possession."

According to Mr. C. Gordon, a Baillon's Crake was taken in the Hythe Canal by Mr. F. Young, in October, 1870. In the Kentish Express and Ashford News, December 22, 1906, it is stated that "a specimen of Baillon's Crake was shot near Lydd on Friday, December 21, by Captain Ir. Alexander."

\section{Genus CREX, Bechstein.}

\section{CORN-CRAKE.}

Crex crex (Linnæus). S.N., i., p. 251 (1766).

Land-Rail.

The Corn-Crake on its arrival soon becomes scattered over the county, and is to be found in all the fields and 
meadows laid down for hay, where its ventriloquial, grating call-note may be frequently heard.

Writing in 184t, the Rev. J. Pemberton Bartlett states that this bird was "not common."

Mr. F. D. Power, in his notes on the birds at Rainham, says: "One flushed in the woods on October 1, 1868." Mr. W. Oxenden Hammond relates that an "extraordinary flight of Land-Rails" occurred in 1869: "Have you heard of the extraordinary flight of Land-Rails which visited this neighbourhood (Wingham) in the early part of September last? Land-Rails are usually very sparsely distributed through this district-an open, corn-growing country-and three or four in a season are about as many as I usually meet with. During the first week of September I found upwards of thirty in three days, and on a neighbouring property the owner killed upwards of fifty (seventeen in one small clover field of two acres), and probably found a good many more. All these birds were lean and poor, and came in with a north-east wind.'

There is one in the Maidstone Museum, obtained near Maidstone on July 24, 1894, by Mr. R. J. Balston. Mr. Walter Prentis states: "On one occasion, when all the young clover seeds failed to grow, I happened to leave my clover field for another year, being the only one in the neighbourhood of Rainham. I shot twentyfive Land-Rails on nine acres in September; this was, however, a most immense event."

Mr. F. A. Mackinnon writes: "I had not forgotten my promise to search my game book at Acrise, in Kent, for details as to shooting Land-Rails, but I was unable to lay my hands upon it during my two days' visit this week; however, I have ascertained it was in 1880 when we shot 211. Our best day that season was thirty-five, 
and the birds were shot in two pieces of clover; while our late head-keeper used often to say that as many more escaped. Other good bags of Land-Rails that season, all in the month of September, were, twenty-six, twenty-one, and twenty, while thirty-seven were shot in August. We grow a lot of clover in my part of East Fent, and it used to be a practice of mine in those days to search for these birds in the clover, not for the sake of the sport, for there is none, but for the pleasure of seeing the young dogs work. There cannot possibly be better training for a young dog than to put him on the line of a Land-Rail, for if he is to flush it, he must lieep his nose to the ground. I may add that 1880 must have been an exceptionally prolific year for these birds, as in no other year that I can remember has the total amounted to 100. My experience has been that a wet summer is the most farourable one for Land-Rails, but the reason of this may be, of course, that in those seasons the clover, into which the bird goes when driven from the corn, grows more luxuriantly, and therefore gives better cover."

\section{Genus GALLINULA, Brisson.}

\section{MOOR-HEN.}

Gallimula chloropus (Linnæus). S.N., i., p. 258 (1766).

\section{Water-Hen.}

This bird being a permanent resident throughout the year, may be seen at all times on every large pond, lake, stream and sewer in Kent, where they breed freely all over the county. 
The nests are so variously placed that it is difficult sometimes to detect them; some are found on the overhanging branches of bushes close to the water on which an accumulation of rubbish is fixed, others among the mass of dead sedges, rushes and iris, and on the banks above the water.

During the winter they are generally found in pairs. In the summer they remain with their young until the latter are able to fly.

They are very numerous in all the districts of East Kent, particularly so in the marshes.

Mr. T. Hepburn says: “Moor-Hens' nests are very numerous in the dykes and pools of water on the marshland near Dungeness. In no cases were the eggs in any of the nests that I found covered with leaves."

\section{Genus FULICA, Brisson.}

\section{COO'T.}

Fulica atra, Linnæus. S.N., i., p. 257 (1766).

The Coot is far less abundant than the Moor-Hen, although it is thoroughly distributed over Kent, especially in the larger lakes, marshes and estuaries, the numbers being increased from the north during the winter.

The Lower Medway appears to be a favourite place during severe winters for these birds, where a great many are usually to be found. Several specimens obtained in that locality by Mr. R. J. Balston are now in the Maidstone Museum. It is not exclusively a river bird, but is found far inland, where it breeds on many of the large inland lakes. For instance, it 
was obtained by IV. Berry, Esq., at Staplehurst, in Kent, and at Bethersden by Captain J. D. Cameron. There is a male and female, nest and eight eggs, in the Maidstone Museum, obtained at Hollingbourne, in Kent, by Mr. J. Coveney, and a male from Leeds, February 22, 1887, obtained by Mr. M. W. Martin.

Mr. T. Hepburn writes, on May 13, 1900: “Found two nests in the reeds surrounding a pool of water on the marsh near Dungeness; two eggs in one and eight in the other. In both instances the eggs were quite fresh."

Specimens were procured in the Orlestone district in January, 1907.

\section{Family GRUID}

Genus GRUS, Bechstein.

\section{CRANE.}

Grus grus (Linnæus). S.N., i., p. 234 (1766).

There is sufficient evidence from the subjoined particulars, culled from the last edition of Yarrell's British Birds, to confirm the existence of the Crane in this county, viz.: "Though at the present time only an occasional and rare visitor to the British Islands, the Crane was formerly much more frequent. In a letter addressed to Boniface, Bishop of Mayence, who died in 755 , the Saxon Fing Ethelbert requested him to send over two Falcons suitable for flying at the Crane in Kent, i.e., Gyrfalcons."

The only other record is that of the Rev. J. Pemberton Bartlett, who, writing in 1844, states that it "has been seen in Romney Marsh." This statement is made without. data. 


\section{Family OTIDIDÆ.}

\section{Genus OTIS, Limnæus.}

\section{GREAT BUSTARD.}

Otis tarda, Linnæus. S.N., i., p. 264 (1766).

It seems that the Great Bustard was well linown in Kent from a very early period, although the records of individuals were never kept, from the fact that in those early times, all those which fell victims to the fowler were for the table, and not for a collection.

Boys includes it in his Birds of Sandwich, 1792.

An old specimen in the Canterbury Museum is supposed to have been shot at Whitstable, but is without data.

A female in the possession of the Rev. C. W. Shepherd, Trotterscliffe Rectory, was discovered at an old furniture shop at Rochester some years ago, and on the back of the case was a label with " Filled at Halling, Kent, 1797."

In the Zoologist, 18.50, Dr. F. Plomley, of Maidstone, writing on January 16, says: I have been fortunate enough to obtain that almost extinct bird in England, the Great Bustard, which was shot at Lydd, in Romney Marsh, on January 4, 1850. The man who shot it informs me that he had in his garden a wounded Wild Goose, and that the Bustard (which he supposed to be a Goose also) had been seen several times, by himself and others, steadily flying over his garden, and that on the moruing of January 4 , as he was standing at his back door, he saw the bird at a distance flying direct towards him; he immediately stepped into his house, got his gun, and lilled the bird as it was passing over his wounded Goose. I believe this to be the only instance of it being lilled in Kent; but from the 
information I obtained during the many years of my residence in Romney Marsh, I think the Great Bustard was not uncommon formerly in that locality. My specimen is a female and in beautiful plumage. It measures, from the crown of the head to the tip of the tail, 2 feet $6 \frac{1}{4}$ inches; across the breast, with the wings closed, $10 \frac{1}{2}$ inches; from the extremity of one wing to the other, when expanded, $5 \frac{1}{2}$ feet. The crop contained a quantity of vegetable matter, principally sea-kale." This specimen is now in the Dover Museum.

In 1859 a young male was killed near Romney, in Kent, by Mr. Whittenden. This bird is now in the Maidstone Nuseum; it was presented by Mr. G. Simmons.

Mr. H. A. Dombrain, of Ashford, in writing to the Zoologist, 1880, says: "I have to report three Great Bustards recently obtained in Kent, viz.: The first of these was shot in Romney Marsh towards the end of December last (1879), the sex of which I have not been able to ascertain. The second, an immature female bird, weighing $8 \frac{1}{2}$ lbs., was taken early in January, 1880, at Great Chart, near Ashford. The third, a full-grown male, weighing $16 \mathrm{lbs}$, was shot near Wye, about the latter end of January, 1880. This bird had been observed by the occupier of the land it was on, and he was anxious that it should be left unmolested, but a trespasser, much to his annoyance, went in pursuit and shot it."

\section{LITTLE BUSTARD.}

\section{Otis tetrax, Linnæus. S.N., i., p. 264 (1766).}

Few instances are on record of the occurrence of the Little Bustard in Kent. 
The first mentioned is that one was killed at Chatham, in Kent, in Jauuary, 1834.

Two specimens were obtained by Dr. F. Plomley in Romney Marsh, according to the Rev. J. Pemberton Bartlett, in his Ornithology of Kent, 1844, so that these birds were obtained before that date. One is now in the Dover Museum. The Rev. C. H. Fielding, in his Handbook of Higham, 1882, adds the Little Bustard to that locality, and says: "Communicated by a friend who claimed to have shot one a few years ago."

Mr. G. Dowlier, in his Birds of East Kent, 1889, says : "But few specimens of this rare bird are recorded from our district; one, now in the Rev. B. Austen's collection, was killed some years ago, in St. Nicholas Marshes."

\section{Family CEDICNEMIDE.}

Genus EDICNEMUS, Temminck.

\section{STONE-CURLEW.}

Gedicnemus adicnemus (Linnæus); S.N., i., p. 255 (1766).

Norfolk Plover; Thick-knee. Night-Hawk.

The Stone-Curlew is now an almost unknown bird in Kent, the persecution which it has undergone, the destruction and robbery of its eggs, have driven it away from this county.

Boys adds it to the Birds of Sandwich, 1792. The Rev. J. Pemberton Bartlett, in 1844, states that it "breeds on the shingle in Romney Marsh." Mr. G. Bensted obtained it at Ulcombe, in Kent, and the specimen is now in his collection. Mr. R. T. Filmer 
says it used to nest on Dungeness beach. A specimen in the Maidstone Museum, a male, was obtained at Aylesford, April 24, 1888, by Mr. R. J. Balston.

Mr. G. Dowker, in his Birds of East Kent, 1889, writes: "A specimen of the Stone-Curlew was shot at Ash; when last met with it was found on that extraordinary accumulation of stones known as the "Lydd Beach." This is not only the home of many rare birds, but is a perfect wilderness, while a famma and flora is found nowhere else to be met with in the south-eastern corner of England. The beach, which has been accumulating round Dungeness for many centuries, is upwards of three miles in width at its broadest part, a stony desert relieved here and there by large ponds, and a sort of oasis surrounded by swamp and tall bull-rushes, the resort of numerous species of wild-fowl and sea birds. The beach still preserves the ridges marking the lines of the former recession of the sea, and crowned in the most ancient ridges with a stunted vegetation of brambles and briar bushes, while lichens and mosses have consolidated the pebbles. Nearer the shore the loose beach, yielding to the steps of the explorer, makes the walking exceedingly laborious, and few save the coastguard men cross it; and they make use of a sort of suowshoe, known by the local name of "baxters," on which they skate along the beach. This isolated and unfrequented spot is now, however, invaded by the iron roads, the railways, and the last retreat of the wild bird is thus threatened."

Captain Boyd Alexander writes (1896): "On May 2.2 a pair of Thick-knee Plovers appeared on the "Lydd Beach." After carefully watching them for some days I was rewarded by finding their two eggs. They were deposited amongst some flowering foxgloves-altogether 
a pretty site-but all the same unhappily selected, since the locality was continually being subjected to a "dropping " artillery fire. I had hopes of being able to see the young, but after four days of sitting the birds deserted the nest. The extraordinary sense of smell possessed by the 'Thick-knee renders a near approach to the nest without disturbing the birds difficult."

Mr. T. Hepburn, in his notes on the birds on the beach at Dungeness, in 1900, writes: "The local name of the Stone-Curlew is 'Night-Hawk.' Several pairs of these birds still breed on the beach, but they are by no means common, and all the coastguards' and fishermen's sons know that the two eggs have a marketable value. May 14, 1900: I saw one of these birds fly up from the beach, and on looking along the ridge from about which it flew, I found its two eggs lying on the shingle. The apology for a nest in which they lay was simply a hollow scratched out of the shingle, measuring about 7 inches in diameter and $\frac{3}{4}$ inch deep. The two eggs were laid fully 2 inches apart, end to end. I was told by a fisherman that they are never laid close together. Surromnding the hollow were several pieces of broom, which had the appearance of having been put there by the bird. One egg was rather larger than the other, and the same fisherman as I have mentioned above said that they always call the larger egg a cock's egg, meaning that a male bird would be hatched out of it. The same day another pair of these eggs were offered to me for sale, and I was informed of a further pair having been found two days previously. This shows that there are several pairs breeding on the beach, and also that they must find it a difficult matter to bring their business to a satisfactory conclusion." 


\section{Family GLAREOLIDÆ. Genus GLARE0LA, Brisson. COLLARED PRATINCOLE.} Glareola pratincola (Linnæus). S.N., i., p. 345 (1766).

On the authority of the Rev. C. H. Fielding, who says: "There is a stuffed specimen of the Pratincole in Lord Clifton's collection, which was the property of $\mathrm{M}$ r. Sivey, a bird-stuffer in Gravesend, who declared it to have been killed in the county."

The second record is that given by Dr. N. F. Ticehurst (Zoologist, 1903, p. 420), who states that on "May 30, 1903, a male Collared Pratincole (Glareola pratincola) was shot by Mr. Southerden at Jury Gap, in Romney Marsh. It was seen by me in the flesh, and exhibited at the British Ornithologists' Club (vide Bulletin of the B.O.C., xcix.). This is probably the first occurrence of this species in Kent." This latter specimen is now in the possession of Mr. Fleetwood Ashburnham, of Broomham Park, Sussex.

\section{BLACK-WINGED PRATINCOLE.}

Glareola melanoptera, Nordm. S'oc. Imp. Mosc., 1842, t. 2.

For the first notice of the occurrence of this species in Kent zoologists are indebted to Dr. N. F. Ticehurst, who states that on "June 1 (190:3) a male Black-winged 
Pratincole (Glareola melanoptera) was shot by Mr. F. Mills near Dungeness Point. This is the first occurrence of this species in the British Isles, and is recorded by me in the Bulletin of the B.O.C., xcix. ${ }^{1}$ This specimen is now in the collection of Mr. Fleetwood Ashburnham, of Broomham Park, Sussex" (Zoologist, 1903, p. 421).

Another example is recorded by Lieutenant Boyd Alexander: "An adult male was shot on Romney Marsh on June 17, by a man named Jones, and is now in the collection of Mr. Fleetwood Ashburnham, of Broombam Park, Hastings" (Bulletin of the B.O.C., vol, xiv., p. 17, 1904.)

\section{Family CHARADRIID Æ.}

Genus CURSORIUS, Latham.

\section{CREAM-COLOURED COURSER.}

Cursorius gallicus (Gmelin). S.N., i., p. 692, (1788).

The records in the last edition of Yarrell's British Birds, 1882-84, of the Cream-coloured Courser in Kent, are as follows: "The earliest occurrence of the Creamcoloured Conrser in England appears to be that of the specimen shot in 1785 by IVilliam Hammond, Esq., of St. Alban's Court, near WVingham, in East Kent, who presented the specimen to Dr. Latham, who gives the following account in his Synopsis of Birds, Supplement

'Tol. xiii., p. 78, 1903. 
i., p. 254, pl. cxvi. (1787): ${ }^{1}$ ' He first met with it running upon some light land, and so little fearful was it, that after' he had sent for a gun, one was brought to him which, having been charged some time, did not readily go off, and, in consequence, he missed his aim. The report frightened the bird away, but after making a turn or two it again settled within 100 yards of him, when he was prepared with a second shot, which despatched it. It was observed to run with incredible swiftness, and at intervals to pick up something from the ground, and was so bold as to render it difficult to make it rise from the ground in order to make a more secure aim on the wing. The note was not like that of any kind of Plover, nor, indeed, to be compared with that of any known bird. "This example, which the plate shows to be an immature bird, passed into the Leverian Museum, and having subsequently been purchased by Donovan for eighty-three guineas, it found its way to the British Museum.

Boys, in his Birds of Sandwich, 1792, includes the Cream-coloured Courser among the birds of that locality, and undoubtedly refers to the bird obtained at IVingham by IV. Hammond, Esq. In a footnote in the last edition of Yarrell's British Birds (vol. iii., p. 241) it is stated: "With reference to that county (Kent), it may be mentioned that Mr. J. E. Harting has furnished the Editor with the following note: 'October 20, 1868: Saw to-day a specimen from the sale of the Margate

' The date is not mentioned, but from the tenor of Latham's letter, dated December 12, 1785, acknowledging the gift (communicated to Mr. J. Gould by Mr. IV. O. Hammond, the grandson of the donor), it would appear that the bird was killed a short time previously. $-\mathrm{H}$. Saunders. 
Museum, said to have been obtained at Westbrook, near Margate, in Kent, November, 1849.'"

Mr. H. J. Harding, writing to the Zoologist, 1866, p. 524, says: Deal, October 10, 1866: "A specimen of this very rare bird was shot near Sandwich by a man who knew nothing about its rarity, and allowed it to spoil ; when it got into my hands it was nearly rotten."

\section{Genus CHARADRIUS, Linnæus.}

\section{GOLDEN PLOVER.}

Charadrius pluvialis, Linnæus. S.N., i., p. 254 (1766).

The Golden Plover is only a winter visitor to Kent, coming in October or November, according to the severity of the season. Some remain on the higher heaths and commons or marshes during the winter, leaving about March or April for the north. Most of them go further south, therefore few are obtained in the county.

Boys adds it to the Birds of Sandwich, 1792, and the Rev. J. Pemberton Bartlett, writing in 1844, states that the Golden Plover is "common." Mr. F. D. Power, in his notes on the birds of Rainham in 1868, says: "I met with a small flock in a neighbouring marsh on October 7. This is an early appearance for them in this district."

There are two males, obtained at Linton on March 11 and 14, 1888, by Mr. H. Kennard, now in the Maidstone Museum.

It has been found in the Orlestone district, East Kent. Being an upland bird, it is more often found in the large open pastures on the hills. 


\section{Genus SQUATAROLA, Leach.}

\section{GREY PLOVER.}

$$
\begin{gathered}
\text { Squatarola helvetica (Limmeus). S.N., i., p. } 250 \\
\text { (1766). }
\end{gathered}
$$

$$
\text { Grey Sandpiper, Boys, } 1792 .
$$

This species is another autumn and winter visitor, more abundant than the former, and is confined to the sea-coast and estuaries of Kent, associating as it does with most of our waders, so very different in its habits to those of the Golden Plover. During the winter it may be seen in larger or smaller numbers on nearly all the extensive mud-flats and beaches along the coast and rivers in the county, feeding in and enjoying the company of Ring Plovers, Dunlin, Godwits, Sandpipers, Whimbrels, Curlew and Gulls. It arrives on the coast about October and November, and remains in greater or smaller numbers until March or April, and occasionally later.

The Rev. J. Pemberton Bartlett, writing in 1844, states that it was "common in Romney Marsh."

Mr. W. H. Power says: "I have only once observed these birds at Rainham. On October 8, 1865, a flock of about fifteen or twenty settled on the mud in the creek; a friend who was with me succeeded in stalking them and shot two. They had nearly completed their autumnal moult."

Mr. F. D. Power, writing in 1868, says: "I first observed the Grey Plover on September 18, 1868, three together. They are never very numerous on the Rainham marshes." It finds its way along the mud-flats high up the Medway and the Thames. 
In Captain Boyd Alexander's notes from Romney Marsh, 1896, he states that "several Grey Plover, with black breasts, were also obtained on May 10, and individuals of this species continued to arrive on and off up to June 13, when I saw two of them in company with a Knot on the Midrips. (These are a series of shallow ponds on the 'Lydd Beach.') By the next day, however, all three had disappeared. On May 22 a flock of six passed over my head. They were making in a northerly direction."

Genus ÆEIALITIS, Boie. KENTISH PLOVER.

Agialitis cantiana (Latham). Supp. ii., Gen. Synopsis, p. lxvi. (1801).

Dr. Latham was the first to describe and name this pretty Plover (Charadrius cantiana), from examples received from Dr. Boys, who had procured them at Sandwich, in Kent, in 1787 and 1791. Boys included this same species in his list of Kentish birds obtained at Sandwich, 1792, under the name of Alexandrine Plover. The Rev. J. Pemberton Bartlett, writing in 1844, says it is "common in Romney Marsh, where it breeds." Specimens of this bird in all stages, from adult to young and eggs, are to be found in nearly all our museums and private collections, and to enumerate the whole would form an excellent catalogue.

In the Zoologist, 1880, the Rev. H. A. Dombrain, writing on the Habits of the Kentish Plover, says: "About the middle of April the Kentish Plover arrives in this country, and as its principal breeding places 


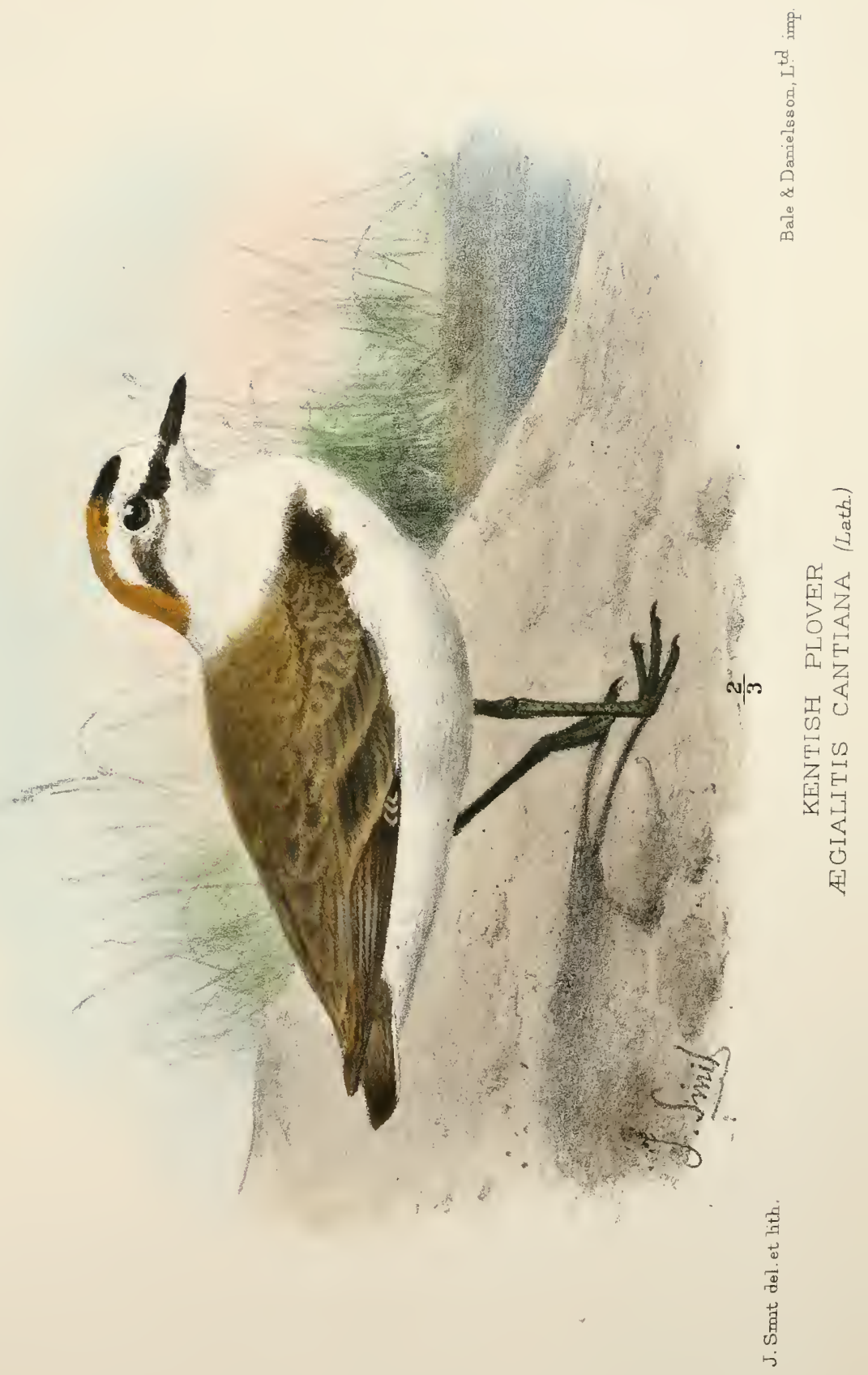



are along the south-east and south coasts of Kent, it at once repairs to these spots. Nidification, or rather, propagation, begins soon after, depending a good deal on the season. The weather in May, 1878, having being warm, the young were hatched by the end of that month; last season being as much against them as the previous one was in their favour, I found eggs only half incubated by the beginning of June. The eggs, which are three in number-not four, as is usual with other species of the genus-are generally laid on the bare beach. Occasionally the bird will deposit them on a heap of seaweed which has been thrown up by a very high tide. The most usual place is on small pebbles through which a little grass grows. IVhere the eggs are so deposited the bird lays its first egg on the stones without any attempt at a nest, but twists a few pieces of the surrounding grass amongst the pebbles, so that by the time the three are deposited there is a scanty apology for a nest. If put off the eggs the bird will retire to a short distance, and after a plaintive whistle, run a few yards, then fly a little, and drop and run again. As soon, however, as the young are hatched, its manner is quite different; it will then fly very close around, giving at each stroke of the wings a sharp whistle, then drop suddenly, as if shot, crouch very close, expand its wing and tail and drag itself along, then suddenly take wing again and go through the same motions, till the intruder is at a safe distance. The callnote is a soft whistle quiclily repeated four or five times. The young, which run as soon as they are hatched, keep close to the parent bird till well able to shift for themselves. The food of this species consists of insects and small worms, which it picks up at the water's edge and on the beach, when its form and manner much resemble 
the Sanderling, the head being drawn in, the body nearly horizontal, and the thighs concealed among the feathers of the under plumage. There is a species of spider which has hitherto baftled my attempts at capture, on account of the rapidity with which it travels among the stones, and which is found in great abundance on the beach, and as the bird is often seen running very nimbly over the stones and occasionally darting its head down, it may fairly be presumed that this insect constitutes a good deal of its food. If the eggs are approached, but not too nearly, the bird may be seen to run among the grass, and every now and then raise itself on its legs and stretch its neck to see and not be seen. It possesses great powers of ventriloquism. I have stood still and tried for some minutes to discover one which was in an entirely different place to what I had supposed from its note. Their favourite place for exercising this is on a moderate-sized stone, where they will stand and whistle for many minutes at a time. I need not describe either the bird or its eggs, as they have so often been treated of."

In Mr. T. Hepburn's notes on the birds of Dungeness, 1902, he remarks: "The Kentish Plover, notwithstanding all vicissitudes, seems to hold its own, and I think I am safe in saying that there were as many birds breeding on the beach in 1902 as in 1900. My fisherman friend, whose acquaintance I made on the occasion of my former visits, gives me some interesting information as to the numbers and distribution of this bird on the beach. During a morning's walk with him we saw two pairs of these birds, and he told me that he knew at that time of three other pairs in different parts of the beach. He also said that he had been recently 
watching twenty or more birds of this species feeding in small mobs on Romney Sands, which he considered to be last year's birds and non-breeders.

"The previous autumn (1901), he told me he had counted forty birds in one flock, which were no doubt getting together preparatory to leaving this country.

"My companion had on the previous day (May 15, 1902) found a nest belonging to one of the pairs of birds we had just seen. On walking towards it we saw one of the old birds rise about thirty yards from us, and it was almost immediately joined by its mate, and both birds flew away quickly out of sight over a ridge. After looking at the nest we concealed ourselves in a hollow, from which we could watch the spot where the nest was. In about ten minutes a single bird came back and settled on the beach not much more than 10 feet from the nest. After a succession of short runs, several of which were made in reverse directions, it stood for a few moments quite still (actually not more than 12 inches from its eggs), and then, with a short, quick run, settled on them. It was such a dull day that it was most difficult to distinguish the bird as it ran over the pebbles, and when it settled on its eggs it aisappeared from my sight altogether. We then again wallied towards the nest, but I failed to detect the bird move from its eggs, and only caught sight of it when it took wing about 10 feet away from its nest. The nest contained three eggs, which I noticed were not all with the pointed ends towards the centre, and was situated on the crest of the ridge of pebbles. The nest hollow was scratched out close to a mossy patch of stones, and it was thiclily lined with short, broken pieces of rotten twigs and sticks. I think this lining of the nest with vegetable matter is unusual. 
The hollow measured 3 inches in diameter by $\frac{3}{4}$ inch deep.

"On May 19 I was rather surprised to disturb three Kentish Plovers feeding along the edge of a swamp three miles inland. There was no doubt about them, as I had a good view of them through the glasses, and could see the broken pectoral band. On May 20 I was watching a pair for some little time on the beach near Littlestone. As it was a bright, sumny day I found them comparatively easy to follow with the glasses. Occasionally they came so close to me that I was able to distinguish all the details of their plumage. They have a whistling call-note, which is not unlike that of a Ringed Plover abruptly cut short in the middle."

\section{RINGED PLOVER.}

Egralitis hiaticula (Linnæus). S.N., i., p. 253 (1766).

Ring Dotterel ; Sea Lark; Stone Plover; Stone-runner.

This is the most abundant species of Plover along the whole of the coast, estuaries and marshes in the county, both winter and summer; at the same time the number's are largely added to during the winter by the birds that are driven down from the north.

The principal breeding-place in Kent is the extensive stony beach from Lydd to Dungeness Point. Boys, in his Birds of Sandwich, 1792, calls this bird the "Sea Lark."

Mr. J. Gould obtained the adult and young of this bird at Dungeness Point, June 12, 1864. 
Mr. W. H. Power, in his Birds Observed at Rainham, 1865, says the Ringed Plover was "first seen on its move southward on July 19. I noticed an instance of the great voracity of crabs. Having shot a Ringed Plover, which fell in the water, I went as soon as I had reloaded to pick it up; not more than two minutes could have elapsed, but when I arrived at the spot where it fell I could only see the tip of one wing some distance below the surface of the water. Upon seizing this and pulling it out, I landed at the same time three crabs; they had already made a considerable hole in the breast of the bird."

The Ringed Plover, writes Captain Boyd Alexander in 1896, “ breeds on the 'Lydd Beach' in fair numbers, and seems to be the least affected of its genus by the artillery practice. These noisy little birds course over the beach all day long, uttering their whistling cries. Even the Sky-Larks of the locality have caught their plaintive notes, and they produce them amongst their own with startling exactitude."

The following observations on this bird at New Romney and Littlestone-on-Sea, were made by Mr. E. F. M. Elms in 1902: "Saw the first Ringed Plovers about half-way between Littlestone and Dymchurch on May 18; watched them running about the shingle for some time, and felt convinced there was a nest near at hand, but was unable to locate it. They (for it was a pair under observation) seemed full of anxiety and uneasiness, and incessantly kept up their tremulous piping. After accomplishing each little run forward over the pebbles they would pause, and seem to cast a sidelong glance at one another.

"On May 20 I spent a considerable time watching 
a pair of Ringed Plovers at exactly the same spot where I saw them on the 18th; they were probably the same pair. Their incessant cry or whistle was a plaintive pip-pip or wip-wip, I could not determine which. This I took to be the note of anxiety, and it was repeated incessantly. Only two or three times during the halfhour I watched them did the note change, and then it was purlin or wurlin. At each utterance the black crescent-like gorget heaved up and down, and my friend thought the piping note was produced without any opening of the mandibles, but I could not ascertain this myself. So quickly did their little feet move over the pebbles that every now and then a faint clatter was audible as a stone was overturned. From this habit of theirs they gain the local cognomen of 'Stone-runners.' Only two or three times did either bird pick anything up with its beak; they were evidently not intent on feeding. Their attitude all along was that of anxiety. Every now and then one would stop and perch itself on the top of one of the larger stones, and proceed to scratch its beak or head with its foot, and as often as not almost toppling over in its endeavours to preen itself and maintain its balance on one foot at the same time. Now one bird begins to move in a series of short, sharp runs from one end of a pebbly ridge to the other-say, about 20 yards-and gradually it comes nearer, and it strikes me that it is zigzagging, or rather, perhaps, lessening the distance between itself and me by a series of everdecreasing radii, with the nest as the centre. Such proves, more or less, to be the case, for, on rising and looking carefully over these thousands and thousands of pebbles, I almost tread on the motionless squatting form of a Ring-Plover chick. It seems a weakling, and likely 
to die, but doubtless it has only been hatched a few hours. I doubt whether the hollow in which it lay was the true nest; and where were the other three? The old birds, though exceedingly clamourous with their pipings, did not in any way feign injury or attempt to draw us away from their helpless young one, in the manner that so many species in this order are in the habit of doing. The eggs of the Ringed Plover are most difficult to find, and one might look over acres of this shingly waste without finding a nest; but, curiously enough, though one hollow on the beach would seem as good as any other, the birds appear to have their own particular favourite spots, and if one is 'in the know' it is far easier to find them. The fishermen's lads know exactly in which part of the beach to look for nests, and are quite adepts at it. The pebbles among which the eggs repose exactly match the buffish-brown ground-colouring of the eggs, and, furthermore, the pebbles in many cases bear black or very dark spottings and markings, almost exactly like those on the egg-shells; in fact, several times I stooped to pick up a pebble that was so much like an egg that I was temporarily deceived."

\section{Genus EUDROMIAS, C. L. Brehm.}

\section{DOTTEREL.}

Eudromias morinellus (Linnæus). S'.N., i., p. 2.54 (1766).

\section{Land Dotterel.}

The Dotterel is only a spring and autumn visitor to Kent, and far from plentiful at any time. It generally keeps to the higher and more open land along the coast.

The Rev. J. Pemberton Bartlett, writing in 1844, states 
that it is "common in Romney Marsh in spring and autumn."

In the Zoologist, 1871, Mr. J. H. Gurney, jun., says: "On September 7, 1871, at Jury Gap, Dungeness, I fell in with five Dotterel at the edge of a brackish pond, which, as is usual with this species, allowed me to come quite near. They are too fat to walk about much, and are very conspicuous a long way off, looking very black when they settle on shingle. I afterwards saw two smaller 'trips.' My attendant knew directly what they were, and they are not considered rare at Dungeness. The specimen which I obtained was a young one, very different from the bird in its winter plumage, or as we get it in spring. I have never seen but three like it."

Mr. IV. Prentis says, in his Birds of Rainham, 1894, that " a young bird was obtained on the Isle of Sheppy, September 18, 1864, and it occurred on the Isle of Elmly, May 3, 1870, and again on May 19, 1876.'

Writing in 1896, Captain Boyd Alexander, in his ornithological notes from Romney Marsh, says: "A pair of Dotterel appeared here on May 29, a rather late date for this species. They remained in a field of young peas close to the shore for several days."

In 1900 Mr. T. Hepburn writes: May 10 to 14: "Saw several pairs of these birds on this visit to the beach at Dungeness, but saw none in June or July."

\section{Genus VANELLUS, Brisson.}

\section{IAAPIVING.}

Tanellus vanellus (Linnæus). S.N., i., p. 248 (1766).

Peewit; Green Plover.

The Lapwing is very abundant during the breeding season in all the large marshy fields in Kent, especially 
in Romney Marsh, which is well covered in most of the low moist fields with the common Rush (Juncus communis), and about Orlestone, \&c.

The last seen of the Lapwings was on November 21. They were then massing in hundreds in Romney Marsh. Some of the great flocks were at a great height, circling round and round until almost out of sight, while other flocks were within gunshot.

The earliest date noted of the return of the Lapwing was on March 6 , in small flocks only, but there are always some in winter. From time immemorial, with all its persecution and robbery of its eggs, the Lapwing still holds its own. Mr. J. Gould, in his Birds of Great Britain, states that "Dr. F. Plomley informed Mr. Yarrell that two hundred dozen eggs were sent from Romney Marsh to Dover alone in 1839," and this has been going on ever since. These birds used to breed on Grange Farm at Boxley in 1857.

Mrr. W. H. Power in his Birds Observed at Rainham, 1865, says: "A few pairs annually remain on the marshes to breed, but I fancy their eggs are generally taken by the shepherds, as I have only once seen a young bird in the neighbourhood."

In $1900 \mathrm{Mr}$. T. Hepburn says, in his notes on the birds on the beach at Dungeness: "May 10 to 14: There were great numbers of these birds on the beach adjoining marshland. Many of them breed right out on the shingle; in fact, they lay their eggs anywhere, either on the grass-land or on the shingle. There is a considerable traffic in their eggs during the early months of the spring. In all of the nests that I found there were clutches of only three eggs, and as they were also hard set, this was the full clutch laid in these par- 
ticular cases. When the nest is made on the shingle there is generally some attempt at lining it with grass, although in one case the eggs were laid right on the stones. July 16 to 21: At this date there was not a single Lapwing to be seen on the beach proper. There were, however, large numbers of them, old and young birds, on the marsh and meadow land, but they seemed to have quite deserted the shingle."

On June 4, 1906, while searching a large mass of rushes in a field in Romney Marsh for various plants, some young Lapwings got up, and, beautifully concealed among these rushes, what appeared at first sight to be some cow droppings, or the sole of an old shoe, turned out to be a young Lapwing just able to fly. It was so closely pressed down at the roots of the rushes that it had been passed at first as nothing particular, the colour and markings resembling the objects referred to.E. Bartlett.

\section{Genus STREPSILAS, Illiger.}

TURNSTONE.

Strepsilas interpres (Linnæus). S.N., i., p. 248 (1766).

During the autumn, winter, and spring the Turnstone visits all the large sand-beaches and mud-flats on the coast and estuaries of Kient, associating with many other waders. The localities in which it has been procured and the data are very numerous; scarcely a list of Kentish birds is without mention of the Turnstone.

Some of these birds make their appearance very early in August and September and remain up to May and June. 
Mr. IV. H. Power, in 1865, says: "Last year (1864) my brother killed one on Angust 26 at Rainham, the first I ever saw in this district. I saw one or two in September, 1865 , but they are rare."

There is an immature female in the Maidstone Museum, obtained at Gillingham on September 6,1894 , by Mr. H. Payne.

Mr. IV. Prentis records "a specimen procured in August, 1892, in summer plumage."

\section{Genus HæMATOPUS, Linnæus.}

OYSTER-CATCHER.

Hamatopus ostralegus (Linnæus). S.N., i., p. 257 (1766).

Sea-Pie; Olive.

The Oyster-catcher is occasionally to be met with on the large sandy flats on the coast of Kent, but not in large numbers, as formerly.

It bred many years ago in large numbers on the "Lydd Beach," but, like many other birds that have been driven away, few, if any, stay now.

Boys, in his Birds of Sandwich, 1792, adds this bird under the name of Sea-Pie, which is called the Olive of Sandwich.

The Rev. J. Pemberton Bartlett, writing in 1844, states that the Oyster-catcher "breeds on the shingle at Romney Marsh."

Mr. IV. H. Power, in his Birds Observed at Rainham, says: "One made its appearance on September 20, 1865 ; my brother, however, gave it so warm a reception that it quickly went off again. It is a decided rarity." 
According to Capt. Boyd Alexander, in his notes from Romney Marsh, 1896: "A solitary pair of these birds may be found breeding annually on the beach not far from Dungeness; but it is doubtful whether any young are ever reared."

There is a young bird in the British Mruseum obtained at New Romney, September 20, from Mr. H. Seebohm's collection.

\section{Family SCOLOPACIDÆ.}

\section{Genus RECURVIROSTRA, Linnæus.}

\section{ATOCET.}

Recurvirostra arocetta, Linnæus. S.N., i., p. 256 (1766).

\section{The Cobbler's Awl.}

In olden times, when Romney Marsh was a wilderness, and before it was drained, laid down in meadow and pasture land, or even cultivated, and few inhabitants existed there, the Arocet had its home and breeding haunts, but at the present day it is one of the rarest visitors to the county.

Dr. Latham, in 1785, states that Boys "twice met with them at Sandwich so early as the month of October." In 1787 he again writes: "Boys says the Avocet appears on the coast of Kent about the middle of April, and departs for the most part at the beginning of September." Boys includes it in his Birds of Sandwich, 1792. The Rev. J. Pemberton Bartlett, in 1844, says it is " not uncommon in Romney Marsh."

In $1849 \mathrm{Mr}$. J. B. Ellman records that "a specimen 




J.Sinit del, et lith

Bale \& Danielsson, Lta inp

AVOCET

RECURVIROSTRA AVOCETTA, Linn 

of this bird was shot about four miles from Rye, by a fisherman, a week or two since (end of March, 1849). These birds are now very rare in this part, though formerly they used to breed here.-Rye, April 17, 1849."

Mr. H. Benson, writing April 29, 1849, says: "A pair of Avocets were shot during the month of March, in the marshes between Ramsgate and Sandwich. The man who shot them told me that they had been seen in nearly the same place for some weeks before. They are very fine specimens; and I do not doubt that, had they remained undisturbed, they would have bred in the marshes."

Writing again on July 14, 1849, Mr. J. B. Ellman states that "another fine specimen of this now scarce bird occurred here last April. In the former occurrence which I noticed there were five in a flock, but only one was procured."

Mr. J. O. Harper, writing December 4, 1850, records that "a specimen of the Avocet was shot at Sandwich on April 22, 18.9, by a gentleman formerly of Lowestoft."

Writing on Jannary 26, 1857, the Rev. C. W. Shepherd, of Trottescliffe, Kent, states that "an Avocet was shot in the marshes, near Rochester, about five weeks ago; it is now in my possession."

In $1858 \mathrm{Mr}$. J. Gardner records the occurrence of the Avocet in Kent: "I have just preserved a fine specimen of this bird for Mr. Gateridge, of Faversham, Kent, shot close to the town. A few years since it was to be found in numbers in this neighbourhood."

Mr. WV. Prentis, in his Birds of Rainham, writes that "only upon one occasion, to my knowledge, has the Avocet been met with at Rainham, which was on September 23, 1887. One was seen flying along a creek 
and shot, a bird of the second year; another was observed soon afterwards."

In the Canterbury Museum there is a specimen, obtained at the mouth of Sandwich Harbour, August, 1895, in Mr. WV. Oxenden Hammond's collection.

In the Zoologist, 1895, Mr. W. Oxenden Hammond, of St. Alban's Court, Wingham, states that "during the last week of August an Avocet was shot not far from the North Foreland, and was brought to me the following day. It was a bird of last year, in very good condition. The shooter reported that there were three in company, only one of which he secured."

On August 29, 1903, Dr. N. F. Ticehurst records that an Avocet was shot between Rye and Lydd, in Kent.

\section{Genus HIMANTOPUS, Brisson.} BLACK-WINGED STILT.

Himantopus himantopus (Linnæus). S.N., i., p. 255 (1766).

The only record of the occurrence of this species in Kent is that contained in Mr. J. E. Harting's Handbook of British Birds, p. 421, 1901. A specimen which was killed at Faversham, Kent, now in the Canterbury Museum.

\section{Genus PHALAROPUS, Brisson.}

\section{RED-NECKED PHALAROPE.}

Phalaropus hyperboreus (Limnæus). S.N., i., p. 249 (1766).

A rare winter visitor to Kent, and few records of its occurrence are to be found. 
The Rev. J. Pemberton Bartlett, writing in 1844, says: "This bird is rare; Dr. F. Plomley has obtained only one specimen."

A young bird from the Isle of Grain, procured on September 26, which came from the Marquis of Tweedale's collection, is in the British Museum.

Mr. G. E. Power says: "On the 28th, 1871, I shot a Red-necked Phalarope, a female and bird of the year. When shot it was balancing itself on a reed in one of the 'fleets' at Rainham. My attention was called to it by its note, which was well known to me. The stomach was full of coleoptera."

\section{GREY PHALAROPE.}

Plualaropus fulicarius (Linnæus). S.N., i., p. 249 (1766).

The Grey Phalarope is a rare autumn and winter visitor to Kent, it lieeps generally to the shore line, the large sandy and mud-flats of the coast.

Writing in 1844, the Rev. J. Pemberton Bartlett states that it is "common in Romney Marsh in autumn."

Morris, in his British Birds, says: "In Kent one was shot swimming on the Thames at Swanscombe in the autumn of 1845 , and reported by Mr. M. C. Cooke."

There is a Kentish specimen in the Maidstone Museum, from Mr. G. Simmons.

Mr. Charles Gordon, writing from Dover, November, 1870, says: "Three Grey Phalaropes were taken in the Hythe Canal by Mr. F. Young, October, 1870.” 


\section{Genus SCOLOPAX, Brisson.}

\section{ITOODCOCK.}

Scolopax musticola, Linnæus. S.N., i., p. 243

(1766).

The well-known Woodcock is not only a migratory bird, but also a resident in Kent. The numbers are greatly increased during the autumn and winter, and many pairs remain and are found breeding in most of the large open woods and pheasant preserves, especially in East Kent.

In 1776 Pennant, in his British Zoology (rol. ii.), states that "they leave England the latter end of February or beginning of March, not but they have been known to continue here accidentally. In Case Wood, about two miles from Tunbridge, a ferw breed almost annually, the young having been shot there the beginning of Angust, and were as healthy and vigorous as they are with us in the winter, but not so well tasted. A female with eggs was shot in the neighbourhood in April."

Latham, in 1785, says: "A brace of them were shot in Chillenden Wood by the gamekeeper to Horace Mann, Esq., Nay 1, 1769, and another brace the day before; they were sitting on their young. A friend of mine met with a female sitting on the eggs, and the male close at hand; she was so tame as to suffer him to stroke her without rising; this was in a wood near Farningham, Kent; and about three years since, in the same wood, a brace of old birds, with five young ones in company, full fledged, were found. Three of the young were taken 
and given to a lady in the neighbourhood; one of them soon died and is now in my possession."

Boys includes the Woodcock in his Birds of Sandwich, 1792. In 1844 the Rev. J. Pemberton Bartlett states that it is "common."

In $1849 \mathrm{Mr} . \mathrm{J}$. WV. Hulke, in his Dates of the Arival of IVinter Visitors to Deal, gives October 13.

Morris records a nest that was found at Seacocks Heath, near Hawkhurst, in Kent, and others near Tunbridge and Goudhurst.

Sir E. Filmer's keeper said that one was shot at Sutton, September 13, 1867. An innkeeper in Maidstone (Mr. R. Dunk) stated that he had once seen a Woodcock boring, and that it used its bill sideways.

Mrr. J. Gould, in his Birds of Great Britain (1873), writes: "I have myself several times received young birds from localities in the counties of Kent, \&c." There is a Wroodcock and young obtained at St. Alban's Court, Wingham, in 1\$90-91, by $\mathrm{Mr}$. IV. Oxenden Hammond, in the Canterbury Musemm. A male which was killed on Jannary 9, 1894, at Linton, in Kent, by F. S. W. Cornwallis, Esq., is in the Maidstone Museum.

In the Orlestone districts the first Woodcock shot in 1902 was on October 13, and in 1903 the first shot was on October 14.

In the Zoologist, 1903, Mr. R. J. Balston wrote "that in the second week of last month (April) a Woodcock's nest was found in a wood in the neighbourhood of Orlestone, Kent. It had four eggs, which had to be taken, as the wood was being cut; they were all fresh and easily blown. Another nest was found with five eggs, which have since been hatched, and the young birds gone off. One of uny keepers informed me that 
there was still another pair of Woodcocks about, and he supposed they must have a nest. We shot thirty-five Woodcocks last season (1902-3), and left several in the hope that they rould stay and breed. In the winter of 1903-4 eighty-nine were shot, and in 1904-5 sixty-eight Woodcocks rere shot in the above districts."

Mr. E. Bartlett, writing on April 17, 1906, says: "I had the pleasure of seeing my first Woodcock's nest in a wood near Ashford, and I was much surprised while being taken by a keeper to the place in which it was situated, and I may say that it was the last place I should have gone to, or loolied for one. It was a large, open wood, sparsely covered with young oak and ash trees, all the lower undergrowth having been cut some time before, so that only a few new shoots from the old stumps remained. The nest of four dark brown, blotched eggs were placed close to an old stump from which a few leafless shoots and branches stood out, giving no shelter whatever at this season. 'The nest itself was merely a depression among the oak leaves, and the eggs so lilie the surrounding dry rubbish and leaves that an expert eye would overlook them. Fortunately at the time of my visit the hen bird was off the nest. The nest was about 20 feet from a well-used footpath, and only protected from passers-by by a low fence, so exposed that a quick eye might have spotted the bird had it been moving about. When I saw the eggs on the 17th I found they were hard set. It had been discovered on the 12th; on the 24th Mr. R. J. Balston found them still intact, but on the 25th the young were hatched and gone. No doubt the eggs were laid about April 5 or 6." 


\section{Genus GALLINAG0, Leach.}

\section{GREAT SNIPE.}

Gallinago major (Gmelin). S.N., i., p. 661 (1788). Solitary Snipe.

Ouly an occasional autumn and winter visitor to Kent. Few instances of its having been obtained are recorded in the county.

The Rev. J. Pemberton Bartlett, writing in 1844, remarks that the Great Snipe is "rare" in Kent. There is a Kentish specimen in the Maidstone Museum presented by Mr. G. Simmons. Morris states that "Mr. Chaffey, of Dodington, has seen it in that place in September, 1850." MIr. G. Dowker, in his Birds of East Kent, 18s9, says: "The Great Snipe has been frequently met with in our marshes, though it must still be reckoned a rare bird; it is, perhaps, ofttimes confounded with the Common Snipe, but when flushed it does not utter the scape cry so universally the case in the Common Snipe."

In the Zoologist, 1894, Mr. W. Oxenden Hammond records that a "Great Snipe (Gallinago major) was shot on October 1 by Captain Plumbe, Royal Marines, who kindly sent it to me. It was killed in the neighbourhood of Deal."

SNIPE.

Gallinago gallinago (Linnæus). S.N., i., p. 244 (1766).

The Snipe is plentiful in all the marshlands in Kent during the autumn and winter, and on their movement southward, according to the severity of the season. 
Many pairs remain to breed in the most suitable places, especially in Romney Marsh (which must have been in days gone by a perfect paradise for the Snipe), where the nests and young have been found for the last few years.

In $1849 \mathrm{Mr}$. J. W. Hulke, of Deal, in his observations on the departures and arrivals of birds at Deal, states that "these birds left in a body on the night of March 16, though a few stragglers remained a few days longer," and that "they arrived on October 21."

Mr. IV. H. Power says, in his Birds Observed at Rainham: "A very early visitant in the autumn. This season (1865) the first occurred on July 27, and my brother once saw one as early as the 20th of the same month. These early birds are, however, only stragglers, the species not becoming at all common till the end of September or beginning of October." No doubt the above-mentioned birds had bred in those marshes. In $1868 \mathrm{Mr}$. F. D. Power writes: "Scarcely to be found at all, on account of the dry state of the marsh ditches. September and October are generally the best months for them here, but I scarcely saw half a dozen during the whole time, and I did not meet with a single Jack Snipe in the Rainham Marshes."

Dr. N. F. Ticehurst, writing to the Zoologist, 1897, gives the following account of the breeding of the Snipe in Romney Marsh. He says: "T'owards the end of April, some three or four years ago, I flushed a Snipe in Romney Marsh; the question immediately occurred to me, Does the Snipe breed here? There are many very suitable places, though none of large extent like there are in the fens. Being well acquainted with the bird during the nesting season in the fen country, I at once 
began to look for the nest, but could not find it. Every year since I have put up three or four in different parts of the marsh in the month of April; but they always seemed to be only feeding, as the places were generally very wet and no nest was to be found. On April 25 (1897) last, however, while hunting a small piece of rough sedge and rushes with my brother, I saw a Snipe get up right at his feet, and, as usual when there is a nest, fly away slowly and close to the ground. The nest was easily found, situated at the top of a tussock, and containing four typical eggs. We subsequently put up several more Snipe, but they were obviously only feeding, and we were unable to find a second nest. So far as I can make out this is the first recorded instance of the breeding of this species in Kent."

Mr. T. Hepburn, in his notes on the birds at Dungeness, 1900, states that on May 13 he "disturbed a single bird of this species by the side of a ditch. My companion told me, however, that he had never heard of a nest being found in the district."

The melanistic type of this species, called Sabine's Snipe (Gallinago sabini, Vigors, Trans. Limn. Soc., 1825, xiv., p. 557), has been procured in Kent. The Rev. J. Pemberton Bartlett, in 1844, records " a good specimen, a female, which was shot on the banks of the Medway near Rochester, October 26, 1824." Mr. G. Dowker, in his Birds of East Kent, 1889, states that a Sabine's Snipe was obtained in East Kent some years ago and is in the Rev. W. B. Delmar's collection. 


\section{Genus LIMNOCRYPTES, Kaup.}

\section{JACK SNIPE.}

Limnocryptes gallinula (Linnæus). S.N., i., p. 244

$$
\text { (1766). }
$$

The Jack Snipe is only an antumn and winter visitor to Kent, and is generally to be found during that time in all the marshy lands of the county, but it is far less abundant than the Snipe. It arrives in Kent about the middle of October, and leaves in Narch and April. Mr. W. H. Power, in his Birds Observed at Rainham, 1865, says the "first occurred this season on October 13, about which time several made their appearance." One was seen in the Romney Marsh, December 24, 1905, and often seen in the swampy fields in the Orlestone district.

\section{Genus LIMICOLA, Koch.}

\section{BROAD-BILLED SANDPIPER.}

Limicola platyrhyncha (Temminck). Man. d'Orn.,

$$
\text { p. } 398 \text { (1815). }
$$

The first record of this species in Fient is that given by Captain Boyd Alexander (Zoologist, 1896, p. 411): An "immature female was shot at Littlestone out of a flock of Dunlin. This, I believe, is the first instance on record of this species having been obtained in Kent."

Mr. L. A. Curtis Edwards records in the Zoologist, 1901, that "an immature female of the 'Broad-billed Sandpiper' was procured on August 31 (1901) last, near Littlestone-on-Sea, Kent. This is the second Kentish example of this species that I have examined in the flesh." 


\section{Genus TRINGA, Linnæus. \\ PECTORAL SANDPIPER.}

Tringa maculata (Vieillot). Nouv. Dict. d'Hist. Nat., xxxiv., p. 465 (1819).

In the Zoologist, 1898, p. 480, Dr. N. F. Ticehurst writes: "I had the pleasure of exhibiting, at the last meeting of the British Ornithologists' Club, the first Kentish specimen of the Pectoral Sandpiper (Tringa maculata). The bird was shot, from a flock of Dunlin, on August 2 last, along the seashore between Lydd and Rye Harbour. It is an adult male, and its dimensions agree almost exactly with those of Mr. Gurney's Norfolk specimens, given in Stevenson's Birds of Norfolk, vol. ii., p. 370. The bird is the property of Mr. Whiteman, of Rye, to whom I am indebted for allowing me to examine and exhibit it."

\section{DUNLIN.}

Tringa alpina, Linnæus. S.N., i., p. 249 (1766).

$$
\text { Purre, Boys, 1792; Ox Bird. }
$$

During the autumn and winter this is one of the most abundant species of Sandpiper on the coast of Kent. It is to be found on all the large sandy beaches and great mud-flats in the estuaries, and high up the rivers, especially the Thames and Medway. There is scarcely a month in the year that the Dunlin is absent from the shores of Kent, and it may be procured in nearly every stage of plumage.

In his Birds Observed at Rainham, 1865, Mr. W. H. 
Power writes that "large 'flings' of these birds were observed in September. They seldom come near the smaller creeks, apparently preferring as feeding grounds the extensive mud-flats towards Sheemess."

Captain Boyd Alexander, in his Ornithological Notes from Romney, March, 1896, says: On "June 3 I saw a number of Dunlins with black breasts; a somewhat late date. So far as my experience goes, nome of the adults remain here during the entire summer. When feeding, the Dunlins seems convinced of the justice of the rule, 'Share and share alike.' Extended order is formed, or when in flocks the rear portion alternately come to the front, and in this way each bird partakes equally of what the tide lays bare."

In his notes on the Birds of Dungeness in 1900, Mr. T. Hepburn writes that on May 10 to 14 " small flocks of this bird are numerous in suitable places on the beach. July 16-21: I did not notice any Dunlin on this occasion."

\section{LITTLE STINT.}

Tringa minuta, Leisler. Nachträge zu Bechst.

Naturg. Deutschl., pp. 74-81 (1812).

This is only an autumn and winter visitor, and not plentiful at any time, but being such a diminutive bird it is easily overlooked; however, it is found on the mud-flats in the esturaries and large sands on the coast of Kent.

Mr. J. Gould states that "a flock of thirty was seen in Romney Marsh in 1839."

It is included in the Birds Observed at Rainham, by Mr. W. H. Power, who says: "Towards the end of July, 1865, I observed one of these birds about a small pool of water; 
it was decidedly wild, and for several days baffled all my attempts to shoot it."

Mr. IV. Prentis, in his Birds of Rainham, states that " a pair was obtained on September 17, 1881 ; they were shot flying along a ditch on an island marsh." There are specinens in the Canterbury Museum, obtained at Sandwich in August, 1887 and 1888, by Mr. IV. Oxendon Hammond. Dr. R. B. Sharpe obtained the Little Stint in Romney Marsh on September 5.

\section{'TEMIMINCK'S STINT.}

Tringa temminclii, Leisler. Nachträge zu Bechst. Naturg. Dentschl., pp. 63-73 (1812).

This Stint is rare in Kent, and appears on the coast not only in the autumn, but from the following particulars it has been taken in the summer.

The first record is that given by Mr. J. IV. Hulke, of Deal, who says: "On September 6, 1850, I shot a fine specimen of Temminck's Stint, which was running about with a Wagtail in a small plash near the beach." Mr. IV. H. Power obtained one in the Rainham Marshes; he writes: "On July 19 (1865) I noticed a bird of this species running along the edge of a pool. Mistaking it for a Sandpiper, I took some trouble to put it up, and having shot it, was greatly surprised to see that I had got a Temminch's Stint. It was a bird of the year, and in plumage differed greatly from an adult of the same species; the markings on the back were almost exactly sinilar to those of Schinz's Sandpiper in Yarrell.

"Again, on September 9, 1865, a pair of these Stints, 1)ying up the creek, passed within range of the sea-wall, upon which my brother and I were sitting waiting, and 
we each killed one. They proved to be adult birds in winter plumage. The above mentioned are the only specimens of this Stint that I ever met with near Rainham.

"On May 22, 1866, my brother, Mr. G. E. Power, found a 'Temmincli's Stint frequenting the marshes in the neighbourhood of Rainham. After some trouble he succeeded in shooting it, an adult female in plumage intermediate between that of summer and winter."

"Again, on the 25th of the same month, he succeeded in obtaining another, also a female. This latter had nearly attained its summer pimmage. We have now obtained five of these comparatively rare Stints during the last ten months, all within a radius of about a quarter of a mile. They are, however, the only birds of the genus that have been heard of in the neighbourhood."

Mr. W. Prentis obtained this bird in the Isle of Sheppey. He also picked up a 'Temminck's Stint in winter plumage on November 1, 1869.

\section{CURIENT SANDPIPER.}

Tringa subarquata (A. J. Güldenstädt). Novi Comment. Acad. Petropol., xix., p. 471 (1774). Pygmy Curlew, Boys, 1792.

It appears from what Mr. H. Seebohm states regarding this bird that "it was first recorded as a British bird by Latham, who obtained an example in 1786 which was shot near Sandwich," but without a reference to Latham's record. Boys, in his Birds of Sanduich, 1792, under the name of Pygmy Curlew, records "a single instance at Sandwich." Pennant, in 1812, writes: 
"Only one instance occurs of this rare bird having been observed in England, which was shot near Sandwich; and we are informed by Dr. Latham ${ }^{1}$ that it differed from the preceding bird from Holland, in the edges of all the feathers being of a pale ochreous colour instead of white. It weighed almost 2 ounces, its length was $8 \frac{1}{2}$ inches, its extent $15 \frac{1}{2}$ inches, its bill $1 \frac{1}{2}$ inches long." In a footnote it is stated that "another has since been met with at Greenwich in August."

Morris states that " another near Sandwich, May, 1833, was shot by Mr. J. Gould."

Writing from Deal in September, 1850, Mr. J. TV. Hulke says: "On August 16 I had the good fortune to shoot the Curlew Sandpiper in its summer plumage; it was associated with a large flock of Dunlins." There is a specimen in the Canterbury Museum which was obtained at Sandwich in 1850.

Mr. H. L. Saxby, writing September 24, 1862, from Sheerness, states: "About a week ago I saw a fine example of this species in the possession of a boy who had just before killed it with a stick, a little above Rochester Bridge. It was extremely fat, and the stomach was full of sand and small worms. I afterwards observed eight more upon some marshy ground near the same spot."

There is a male and female, obtained in Romney Marsh in September, by Dr. R. B. Sharpe, in the British Museum.

In 1871 Mr. J. H. Gurney, jun., writes: "on September 8, at Romney Bay, near Lydd, I killed three Pigmy Curlews."

${ }^{1}$ Gen. Syn., Suppl., iv., 1. 291, 1787. 


\section{PURPLE SANDPIPER.}

Tringa striata, Linnæus. S.N., i., p. 248 (1766),

Although the Purple Sandpiper has been obtained on nearly every part of the coast and in all the estuaries of Kent, driven there by stress of weather from its native haunts, and out of its element in such situations as this coast affords, preferring a wild and rocky coast with masses of stones and rocks for hiding places, among which it creeps, rat-like, from intruders and the weather, seeking among them what the sea may cast up for food, it only remains for the autumn and winter, leaving again early in Narch.

\section{KNOT.}

Tringa canutus, Linnæus. S.N., i., p. 2.51 (1766). Ash-coloured Sandpiper.

The Knot is a regular autumn and winter visitor to the coast and all the large mud-flats in the estuaries of Kent. With regard to the numbers, it depends on the severity of the season. On the large mud-flat of Pegwell Bay and in the Medway great mobs of these birds may be seen at low tide, associating with all the other waders. and Gulls.

It appears from the data obtained, that the Knot is scarcely ever absent from the Kentish coast; there are always a few stragglers left during the summer, and in the full red plumage. These are no doubt non-breeders. or barren birds.

Boys, in his Birds of Sandwich, 1792, calls this bird, the "Ash-coloured Sandpiper:" 


\title{
Genus MACHETES, Cuvier.
}

\author{
RUFF. \\ Machetes pugnax (Linneus). S.N., i., p. 247 \\ (1766).
}

Ruff and Reeve; Greenwich Sandpiper.

Under the name of Greenwich Sandpiper, Latham, in his Gen. Syn., Suppl., i., p. 249 (1787), says: "The above was shot at Greenwich, on Angust 5, 1785, by Dr. Leith, who did me the favour to add it to my collection. I esteem it a new species. He subsequently named it Tringa grenovicensis."

Boys, in his Birds of Sandwich, 1792, placed this species under the name of "Greenwich Sandpiper." Evidently these refer to the male bird in winter plumage.

In $18+4$ the Rev. J. Pemberton Bartlett states that the Ruff was "common in Rommey Marsh in spring and autumn."

In 1871 Mr. J. H. Gurney, jun., says: "On September 8, at Romney Bay, near Lydd, I killed a young Reeve. I also received one from Faversham, in Kent."

In the Maidstone Museum there is an immature female, obtained at Gillingham, August 2, 1894, by Mr. H. Payne.

The Ruff and Reeve have of late years become rare birds in Kent. 


\section{Genus CALIDRIS, Curier.}

\section{SANDERLING.}

Calidris arenaria (Linnæus). S.N., i., p. 251 (1766). Ox-Bird.

During the autumn and spring the Sanderling is usually found associating with the rest of our waders on all the large sands and mud-flats on the coast and estuaries of lient.

Mr. J. A. Clarke says that Mr. R. M. Presland shot one at Gravesend in the spring of 1864 .

Specimens in Mr. E. T. Booth's collection at Brighton, in winter plumage, were obtained in March, 1866, between Rye Harbour and Dungeness Point, and others in autumn plumage were obtained in September, 1869, on the Kentish coast.

Captain Boyd Alexander, in his notes from Romney Marsh, 1896, writes: "On May 29 the first flock of Sanderlings appeared. They were in full summer dress. The female of this species seems more backward in assuming the nuptial dress than the male. A female out of this flock was obtained with plumage hardly differing from that attained in autumn. The resemblance in the markings of the crown, nape, and mantle, and especially the latter, of the male Dunlin and Sanderling in summer dress, is very remarkable. The last flock of Sanderlings was seen here on June 2." 


\section{Genus TRINGö̈DES, Bonaparte.}

\section{SANDPIPER.}

Tringoides hypoleucus (Linnæus). S N., i., p. 250 (1766).

\section{Summer Snipe.}

This Sandpiper is certainly not plentiful in Kent at any time. A solitary bird or at most a pair may be seen on the banks of the rivers and coast, but as a rule on fresh-water streams.

Boys includes it in his Birds of Sandwich, 1792. The Rev. J. Pemberton Bartlett, in 1844, says it is "common in spring and autumn." In Mr. W. H. Power's Birds Observed at Rainham, 1865, he says: "It is a curious fact that very few common Sandpipers, and few, if any, Green Sandpipers, visit Rainham on their spring migration northwards, although both species become tolerably abundant in the autumn. I noticed the first this season (186.) on July 7, and the last on October 13, the latter being in company with a Green Sandpiper. This is later than I ever remember to have seen one, although last year (1864) I observed one as late as the 1.2th of the same month."

There is a pair in the British Museum, obtained in July and September, in Romney Marsh, by Dr. R. B. Sharpe. Mrr. R. J. Balston generally met with it on the Nedway in summer.

In Captain Boyd Alexander's notes from Romney Marsh, in 1896, he writes: "On May 30 two pairs of Common Sandpipers came to one of the dykes, but disappeared a few days later. I have searched in vain for 
the nest of this species in many parts of Kent, and have carefully watched the birds, but they never remained for any length of time in one locality. The breeding haunts of the Common Sandpiper must be loolied for on higher altitudes than are to be found in Kent and Sussex."

There is no record at present of the occurrence of the nesting of this Sandpiper in Kent.

\section{SPOTTED SANDPIPER.}

Tringoides macularius (Linnæus). S.N., i., p. 24? (1766).

Mr. J. L. Bonbote, at a meeting of the Britisl: Ornithologists' Club, exhibited on behalf of Dr. N. F. Ticehurst, a pair of the Spotted Sandpiper (Tringoides macularius), which bad been shot on May 5, 1904, in a ditch between Lydd and Brooklands, in Romney Marsh. The birds were examined in the flesh, when still perfectly fresh, by Dr. Ticehurst, on May 7. This was the first properly authenticated record of the species in the count? of Kent" (Bulletin of the B.O.C., vol. xiv., pp. 84-85.).

Genus HELODROMUS, Kiap. GREEN SANDPIPER.

Helodromus ochropus (Linnæus). S.N., i., p. 2.50 (1766).

The Green Sandpiper appears to be rather an erratic visitor to the county, but the greatest numbers arrire during the autumn migration. From observations made 
there is scarcely a month between March and December but what a Green Sandpiper may be seen in the large open woods or marshes.

In $1865 \mathrm{Mr}$. W. H. Power writes that the Green Sandpiper" "appeared on its migration southwards on July 17, at Rainham. They soon became tolerably common, but are very wary, generally stationing themselves at a bend of a stream or sheet of water, and whisking round a corner when flushed. 'They often remind one forcibly of a Snipe-the cry uttered almost immediately on taking wing, their subsequent rising high in the air and flying to a great distance, sometimes returning again near to the spot from which they were flushed; in fact, I fancy that the Green Sandpiper is sometimes mistaken for a Snipe by rustics, and may perhaps account for the tales one hears of Snipe being seen at Midsummer. I saw a Green Sandpiper as late as October 13."

In $1868 \mathrm{Mr}$. F. D. Power, in his notes on the birds at Rainham, says the Green Sandpiper is "very scarce this year-a striking contrast to their great abundance here in 1867. This scarcity is to be attributed to the drying up of the ditches during the summer. I saw only two specimens throughout September."

There are specimens in the Canterbury Museum from the Isle of Thanet, obtained in April and May, 1887, and August, 1888, by Mr. IV. Oxenden Hammond; he also shot it on September 7, 1897. Dr. R. B. Sharpe obtained it in Rommey Marsh in September. A male in the Maidstone Museum, obtained at Linton, April 28, 18si, by $\mathrm{Mr}$. H. Kennard; and a male obtained at Leeds, Kent, December 14, 1883, by $\mathbf{M I}_{\mathrm{r}}$. MI. TV. Martin. 


\section{Genus TOTANUS, Bechstein.} WOOI)-SANDPIPER.

T'otamus glareola (Gmelin). S.N., i., p. 677 (1788).

Very few records of the occurrence of the WoodSandpiper in Kent have been made. It appears to be a rare bird in the county.

Mr. J. Green, of Woolwich, writing on June 1, 1850, says: "A specimen of this Sandpiper, just shot by a gentleman at Woolwich, has been brought to me for preservation."

In the Zoologist, 1867, p. 991, Mr. F. D. Power, writing on October 2, 1867, gives the following account of an extraordinary flock of Wood-Sandpipers at Rainham: "On July 26 last (1867) my brother, Mr. G. E. Power, fell in with a large party of Wood-Sandpipers on some marshes near Rainham, Kent, a sudden change of wind on the previous night, viz., from south-west to north and north-east, with a deluging rain, having apparently driven these birds out of their usual line of migration. At first he put up but three, one of which he shot, but at the report others rose on all sides, and joining in one large flock, flew round and round at some height, continually whistling; their numbers he estimated at from eighty to one hundred. They soon pitched again, and, dividing into small parties, flew round the ditches like Dunlins. He followed them up, and without any difficulty succeeded in obtaining four more. The last was seen on September 6. I may mention that we had only twice previously met with this species at Rainham, viz., one seen in July, 1865, and a second which I obtained on 
July 15 last (1866), on the same marsh where this large flock appeared."

A specimen in the Canterbury Museum was obtained at Thanet, July, 1886, by Mr. W. Oxenden Hammond.

\section{REDSHANK.}

Totanus calidris (Linnæus). S.N., i., p. 252 (1766).

\section{Tooke.}

The Redshank is more or less a resident in Kent, but the numbers diminish during the more severe winters, returning in the spring. These birds haunt nearly all the large swampy, rush-corered pastures in the extensive marshes on the coast of lient, breeding and associating with the Lapwing.

Mr. WV. H. Power, writing in 1865, aptly describes the habits of the Redshank in the breeding season: "A number of these birds breed annually on a large piece of marsh called "Rainham Saltings"; this consists of about one liundred acres of irreclaimable marsh-land, intersected in every direction by creeks and dylies; it is traversed by means of a "stray-way," a path that donbles and turns about in every direction to avoid the large creeks, giving to a person following it the appearance of a man demented - at one minute leading straight out from land, the next apparently walking back again; now turning to the right hand, now to the left, occasionally disappearing altogether from view in a dyke. During spring tides the greater part of the marsh is submerged, the higher hillocks only remaining uncovered. 
"The Redshanlis pair about the middle or end of April, and at this time are constantly on the move, flying round and round in circles, incessantly uttering their sharp note with great animation, occasionally rising and falling in the air with a tremulous motion of the wings, and at the same time making a trilling noise. It appears to me that these birds never rest; I have heard them at all hours of the day, and on a still night their cry sounds particularly wild and pleasing. Besides their note uttered when on the wing, they are in the night in the habit of joining in a chorus (if I may so term it), one bird beginning and others chiming in one after another, much in the same manner as a flock of ducks assist the old drake in his clamorous wheezing.

"It is by no means an easy matter to find a Redshank's nest, as, in the first place, as soon as they perceive an intruder on their domain, they immediately commence flying round, uttering loud cries, in the manner before described, and if a dog is present, dashing at it much in the same way as the Curlew. They continue this circling almost incessantly until the intruder retires, but seldom settling, and then only for a short time. In the next place, supposing a bird is marked down, even then one part of the marsh is so much like another, and a circuit being generally necessary to avoid creeks, \&c., a person gets perfectly bewildered in a very short time. I was once so fortunate as to capture a youngr Redshank that was apparently not many hours old. Hearing a low chirp some distance ahead, I went forward, but almost immediately heard it again behind my back. I continued walking, first in one direction, then in another, but always with the same result; I had no sooner got close, as I thought, to the spot, than I heard the bird in quite 
a different direction. At length, having come to a standstill in my uncertainty, I happened to cast my eyes on the ground at my feet, and immediately discovered my little ventriloquist perched on the top of the long stalk of a marsh plant. I thought at first that my hearing the chirp in so many directions was caused by a number of these young birds, but after capturing the above mentioned the note entirely ceased. About the end of July Redshanks begin to flock, and at the same time become wild and difficult to approach. Their flight when in full speed is amazingly swift, and a large flock of them affords a very pretty sight dashing along a creek, first wheeling in one direction, then in another, uttering their cry incessantly all the while."

The nest is of very slight structure, formed of grass and bits of rush: it is placed in a tuft of grass cr rushes. 'The eggs are four in number.

\section{SPOTTED REDSHANK.}

Totanus fuscus (Linnæus). S.N., i., p. 243 (1766).

This species is an occasional spring and autumn visitor to Kent, but it is far from being plentiful, although many of them no doubt are mistaken for the ordinary Redshanks when in winter plumage.

The Rev. J. Pemberton Bartlett, writing in 1844, says it is "to be met with occasionally in spring and autumn in Romney Marsh." Mr. J. Gould writes that the gumners of the Lower Thames and Medway often meet solitary individuals in the months of August and September. There is an immature male in the British Museum obtained at New Romney, on September 22, by Colonel Irby. 
In $1889 \mathrm{Mr}$. G. Dowlier records the appearance of the Spotted Redshanks, which he says was shot "by my" son, on September 9 (1889), by the River Stour. It is a fresh addition to my list of East Kent birds."

Mr. W. Prentis, writing in 1894, states that "on one afternoon I met a pair in the front of a snowstorm in mid-winter at Rainlıam."

Mr. J. B. Nichols states that "on May 29, 1905, a fine. pair of Dusky Redshanks (Totanus fuscus), in summer. plumage, were shot at Jury's Gap, Lydd, Kent."

\section{GREENSHANK.}

\section{Totanus canescens (Gmelin). S.X., i., p. 668 (1788).}

An occasional spring and autumn visitor and at no time numerous. It visits the large outlying sands and mud-flats on the coast and estuaries of Kent, associating with the Godwits, for which it is often mistalien.

Boys includes it in his Birds of Sandwich, 1792. The Rev. J. Pemberton Bartlett, writing in 1844, states that it is "not common. A good specimen was shot last year (1843) at Milton, by the keeper to Matthew Bell, Esq., of Oswalds." Morris says one was obtained at Swanscombe, in Kent, in 18+8, by R. O. White, Esq.

Writing in 1868, Mr. F. D. Power, in his notes at Rainham, says the "Greenshanks appear to have been more abundant than usual on the marshes at the mouth of the Medway. I have heard of several being lilled during September, and we received one in the flesh which had been shot on the 16th of that month." 
A female obtained at Sittingbourne in August, and a female from Romney Marsh, obtained August 2.7 , are in the British Museum.

\section{Genus MACRORHAMPHUS, Leach.}

\section{RED-BREASTED SNIPE.}

Macrorhamphus grisens (Gmelin). S.N., i., p. 6.58 (1788).

It is stated in Pennant (vol. ii., p. 53, 1812) that "a small flock of these rare birds appeared on the coast of Devonshire in the spring of 1803 , and were traced as far as Sandwich in Kent."

There is a Kientish specimen of the Red-breasted Snipe in the Exeter Museum, the bequest of the Rev. Bower Scott.

\section{Genus LIMOSA, Brisson.}

\section{BAR-TAILED GODIVIT.}

Limosa lapponica (Limniens). S.N., i., p. 246 (1766).

Common Godwit, Boys, 1792.

Early in autumn this bird makes its appearance on all the large mud-flats of the estuaries in Kent. Mobs of them may be seen on the most prominent points of sands along the coast, associating with Curlews and Gulls and the smaller Sandpipers. They remain on the coast during mild weather up to December, and small numbers visit these shores on their return in spring, and have been obtained as late as the middle of May. 


\section{BLACK-TAILED GODIVIT.}

\section{Limosa agocephala (Limnæus). S.N., i., p. 246 (1766).}

\section{Jadreka Snipe.}

This bird is now very rarely met with on the coast of Kent. They generally lieep to the large open mud-flats and sands, in company with the other warders. Most of those which have been procured are antumn arrivals.

Boys adds this species to his Birds of Sanduich, 1792, under the name of "Jadreka Snipe."

There are specimens in Dr. F. Plomley's collection at Dover; Mr. W. Oxenden Hammond's collection at Canterbury, and one from Sandgate in the British Inseum.

Mr. W. Prentis, in his Birds of Rainham, says: "In the month of January, 1891, sereral immature Blacktailed Godwits were met with on the Medway saltings, and on October 20, 188.2, a pair of adult Black-tailed Godrits were found on the Medway creek, one being shot."

\section{Genus NUMENIUS, Brisson.} THIMBREL.

Numenius phreopus (Linnæus). S.N., i., p. 243 (17666). May Bird.

A spring and autumn visitor, being more numerous during the spring immigration. In their passage they associate with the Curlews, Godwits and other waders, 
on the great mud-flats and sands round the coast and rivers of Kent.

Mx. W. H. Power, writing in 1865, says: "I noticed that Whimbrels became more numerous towards the latter end of April and beginning of May in the Rainham district. They did not stay long, however, soon leaving us for their breeding grounds. They returned again in the autumn rather before the Curlew, viz., about the end of July, and they became very common towards October, when the greater number left us. A few, however, generally remain during the winter."

Captain Boyd Alexander met with it on the "Lydd beach on September 9, 1896, for the first time." Mr. T. Hepburn, on May 13, 1900, "picked up a recently shot specimen in Romney Marsh near Dungeness." Mr. R. J. Balston met with it on the lower Medway.

Specimens in the British Museum were obtained in Rommey Marsh in May, August and September, by Dr. R. B. Sharpe.

\section{CURLEW.}

Numenius arquata (Linnæus). S.N., i., p. 242 (1766).

Whaup.

This wild and clamorous bird returns to the large sands and mud-flats on the coast and estuaries of Kent in small parties in April and May, remain but a short time, and then go north. On their southern migration they may be found in great flocks massed on the large mudflats early in August and September, and if the season be 
severe the mobs soon become reduced; a few, however, remain scattered along the coast in winter.

Mr. IV. H. Power, in his Birds Observed at Rainham, 1865, states: "The Curlews returned to the marshes this autumn about the second week in August. The young birds, on their arrival, are not nearly so wild as they afterwards become when collected into flocks, and are killed in numbers by the fishermen and "muddiggers." Their mode of proceeding is to take with them a trained dog, as much like a fox as possible; after hiding in a dylie they send the dog out on the mudflats left bare by the receding tide; as soon as the Curlews see the animal they almost invariably attack it, flying round and round, uttering loud cries and occasionally making a pounce at it. The dog, who understands his business well, beats a retreat towards the spot where his master is hidden. The Curlervs follow up their success with vigour, but to their confusion, for as soon as they are well within range the man shoots one, and reloading, does the same again. So engaged are they with the dog that sometimes as many as three are killed before the others take themselves off. Should the sportsman (if he may be so called), however, show himself during the process, the birds would quickly be off. This mode of shooting them can only be practised when they are in small parties of four or five; when in large flocks they do not take the slightest notice of the dog, or of the "Curlew whistle," which is also used to attract them. What is the cause of their attacking the dogs in this manner? Is it aversion, curiosity, or fascination? The fishermen account for it by supposing that foxes are common in the places where they are bred, and that they therefore have good cause for their apparent anger and aversion." 
There are some fine specimens in the Maidstone Museum, obtained in the Lower Medway by Mr. R. J. Balston. He also observed it in the Orlestone district.

Captain Boyd Alexander, in 1896, writes: " On August 24, strong south-westerly wind. Three big flocks of Curlew, each numbering on an average 200 birds, have come to the Lydd Beach. They appeared from the north-eastward."

Mr. T. Hepburn, in his notes on the birds on the beach at Dungeness in 1900, writes: "May 10 to 14 : Saw single birds, and also small flocks of this species flying inland from the sea-coast.

\section{Family LARID正. \\ Genus STERNA, Brisson.}

\section{ARC'TIC TERN.}

Sterna hirundo, Linnæus. S.N., i., p. 227 (1766).

There is no doubt that much confusion occurs respecting this bird and the ordinary Tern on the coast of Kent. This and the following species resemble one another to such an extent that at a distance it is only an expert observer who can detect the difference. Under these circumstances the Arctic Tern may be more numerous than is supposed.

These Terns frequent our shores during the summer, arriving about April and May, and depart in August and September, or later in October. It is at present uncertain whether this species has really bred on the beaches of Kent for many years past. 
On October 3, 1867, Mrr. A. H. Sime writes: "I had the good fortune to obtain a fine specimen of this Tern, a young male in immature plumage, in the Lower Hope, near Gravesend. It was flying at the time in company with four or five others of the common variety. I had seen them flying about the yacht for more than half an hour before they came within shot."

Mr. G. F. Nathew, writing from Sheerness, September 16, 1869, says: "The late gales have driven a number of Ter'us into the Medway; on Sunday last I saw a flock of thirty or forty busily engaged fishing within a very short distance of our sea-wall. As far as I could judge they were all of the same species, viz., Sterna arctica."

Mr. T. Hepburn, in his notes on the birds at Dungeness, in 1902, says: "I suppose there is a possibility of a few Arctic Terns (S. macrura) breeding on the beach. I watched a pair of them for some time one afternoon fishing in the outer bight of a kettle-net. They came so close to me that I was plainly able to distinguish the grey colouring of the breast and flanks."

\section{TERN.}

Sterna fluviatitis, Naumann. Isis, 1819, p. 1848. Sea-Swallow; Kip.

During the summer this Tern, usually called the Common Tern, is to be seen along the coast and all the estuaries of Kent, skimming and hovering over the water in search of food, dropping like a stone every now and again to pick up a dainty morsel from the ripples. 
One of the principal breeding places of this bird in the county is the great shingle beach at Dungeness.

Mr. W. H. Power, in his Birds Observed at Rainham, 1865, writes: "This species was first seen this season about the latter end of July, from which time until the end of September they might constantly be seen beating the creeks in a most methodical manner." Mr. F. D. Power, in 1868, says: "It is very abundant this year in the Rainham marshes, and continued numerous until the end of September. Small parties of about a dozen seen early in October, and for the last time on the 10th. Inmature birds predominated largely-I should think quite fifty to one."

Captain Boyd Alexander, in his notes on the birds at Dungeness, 1896, writes: "The restricted breeding area taken up by the Common Tern is distinctly prejudicial to the safety of their eggs. The children of the fishermen and coastguard officers soon discover these spots, and the eggs are robbed right and left for the purpose of eating. Over these places sheep have invariably been feeding, and where they have poked their noses, forming small stone-padded hollows, the eggs are more often than not laid. On May 21 a nest of the Common Tern was found containing five eggs. They were of the reddishbuff variety."

In Mr. F. Hepburn's notes on the birds of Dungeness, 1900, he says: "May 10 to 14 . There were plenty of these birds about the beach and sea-coast at this date, but they had not yet begun to lay. June 3 to 4: Now nesting in considerable numbers on various parts of the beach. As a rule the birds were congregated into colonies, but I found two separate nests in quite isolated positions. In the colonies the nests were on an average 
15 to 20 yards apart. The variation in colour and in size of the eggs, even in the same nest, was very great. Their nests-merely a shallow scrape-out in the shingle-were in most cases lightly lined with dry grass. In several instances I found eggs indented and cracked, due no doubt to the unevenness of the bottom of the nest, causing undue weight on one portion of the egg when the bird is sitting on the nest. At this date I found eggs with the young birds beginning to form, and others quite fresh. In 1902, the earliest date on which I heard of the Common Tern's egg being found was May 16, and I saw some myself on May 18."

\section{ROSEATE TERN.}

Sterna dougalli, Montagu. Ornith. Dict. Suppl. (1813).

On the authority of the Rev. J. Pemberton Bartlett, who, writing in 1814 , states that it "has been seen in Romney Marsh." Mr. G. Dowker, in his Birds of East Kent, 1889, states that it is "said to have been met with by Colonel Cox."

\section{LITTLE TERN.}

Sterna minuta, Linnæus. S.N., i., p. 228 (1766).

"Skerrek."

This pretty Little Tern is a summer visitor to the coast of Kient, and its principle breeding haunts are the Lydd Beach and some sandy beaches about the Isle of 
Grain. Writing in 1844, the Rev. J. Pemberton Bartlett states that this species was "common in Romney Marsh."

Mr. F. D. Power, in his notes on the birds of Rainham, 1868, says: "We had an immature specimen brought to us alive on September 11; it was discovered inside the sea-wall, and was caught with difficulty. Very common here."

Mr. J. Gonld, in his Birds of Great Britain, says : "During a visit to Dungeness on June 12, 1864, I saw many sitting on their two eggs; none were then hatched, but two young birds were sent to me from thence on the $2 \cdot 2$ nd."

In Captain Boyd Alexander's notes from Romney Marsh, 1896, he says "Of the two species of Terns breeding here, the Common and Lesser, the latter is by far the more numerous. But the numbers of both have sadly diminished of late years. Both species keep separate in their breeding haunts, the Lesser Tern preferring rather the close proximity of the sea." In 1900, Mr. Hepburn makes the following observations on this species on the beach at Dungeness: May 10 to 14 : "Common about the beach, but not yet started laying. June 3 to 4: Found them nesting in small companies in a good many places on the beach. They seem to choose places where the shingle is small and comparatively fine, and often do not even trouble to make the usual slight scratchout, laying their eggs in a chance depression, such as footsteps. The nests in these colonies were generally rather closer together than in the case of the Common 'l'ern, say about 8 to 10 yards apart. There was no real attempt at lining any of the nests I saw, although they occasionally had an odd blade of grass in them. 
Several of the eggs I found were showing signs of incubation. 'There was not quite so much variation in the colour and size as in the eggs of the Common Tern. 'I'he complement of eggs in both species seems to be either two or three." In a very lengthy and interesting account of the breeding of the Lesser Tern, given by Mr. T. Hepburn in his notes of the birds of North Kent, 1902-3, the following particulars are given: "The colony of Lesser Terns which I have had under observation now for three successive seasons, it is pleasant to be able to say so, seems to be increasing in numbers. The birds make their appearance in April, being then seen in small parties fishing along the coast and creelis in the vicinity of their nesting ground. The earliest date on which I have a note of them is April 20, 1902; but I do not give this as the date of their arrival, because my observations have not been continuous enough to fix that date; althongh during a visit to the beach on April 14, 1903, I saw no signs of them, and should therefore be inclined to put the date of their arrival as somewhere between April 14 and 20. 'T'hey do not congregate on the beaches where they nest until towards the middle of May. On May 20, 1903, I found them in numbers on their own particular stretch of beach, and I was rather surprised to find two nests with one egg in each; this is the earliest date on which I have found their eggs. From the first start of laying, I am of opinion that any day one would be able to find fresh eggs, and eggs in all stages of incubation. The only eggs I have taken from this colony have been acquired simply with a view of testing the times of laying. Thus an egg from a nest containing three, taken on May 26, 1901, was so hard set that I could hardly blow it. (This would put the first laying 
for this nest earlier than May 20.) At the same date an egg from another nest was perfectly fresh. On June 18, 1903, I found a single egg which I thought had been laid since a visit on the previous day, and upon blowing it my surmise proved to be correct. On June 25, 1902, a single egg laid in a nest proved to be quite freshly laid, as did also an egg apparently laid by chance on the beach. At the same time, June 18, 1903, I handled nestlings just hatched out; and on June 28, 1902, I caught nestlings beginning to flutter orer the beach which had the primary quills quite long."

\section{CASPIAN TERN.}

Sterna caspia, Pallas. Nov. Comm. Petrop., xiv., p. 582 (1769).

The only record of the occurrence of this rare visitor to Kent is taken from Mr. J. H. Gurney's list of the specimens linown to have occurred in England: "One, Lydd, Kent, prior to 1845. Reported by Mr. E. P. Thompson, Notebook of a Naturalist, p. 265" (Zoologist, 1867, p. 457).

There is one in Dr. F. Plomley's collection which was procured in the channel off the coast of Kent.

\section{GULL-BILLED 'TERN.}

Sterna anglica, Montagu. Omith. Dict. Suppl. (1813).

The only instance of the occurrence of this species in the county is one that Mr. W. Yarrell records in his British Birds. It was killed in Kent in June, 1839. 


\section{SANDWICH TERN.}

Sterna cantiaca, Gmelin. S.N., i., p. 606 (1788). Boys' Tern.

This beautiful Tern was first described by Dr. Latham under the name of Sandwich Tern, in his General Symopsis of Birds, vol. iii., part ii., p. 357, 1785. He writes: "This species is pretty common on the coast of Fent in the summer months, and breeds there; frequents that of Sandwich in vast flocks, and makes a screaming noise. Nay be supposed to lay their eggs among the roclis in the month of June, and hatch them before the middle of July, as I have received the young birds from that diligent naturalist, Mr. Boys, the end of August, 178t. About the same time a young bird, with nearly the same markings, was shot by Dr. Leith, of Greenwich, on the banks of the Thames near that place." In his Supplement, i., p. 266, 1787, he says: "Boys has informed me that it is found to associate with the Common Term. The Sandwich Tern is generally to be seen in the neighbourhood of Romney about April 17, and departs about September 5." At p. 296, loc. cit., he names it Sterna sandvicensis.

In 1788 Gmelin described it under the name of Sterna cantiaca, which should be adopted for the species, although Latham's Sterna sandvicensis has priority. Again, even after Gmelin had named it, Latham renamed it Sterna boysii, in his Index Ornith., vol. ii., p. 806, 1790.

Mr. R. T. Filmer says it is rare, but is to be seen in the breeding season on the large piece of open water near Dungeness Light. 


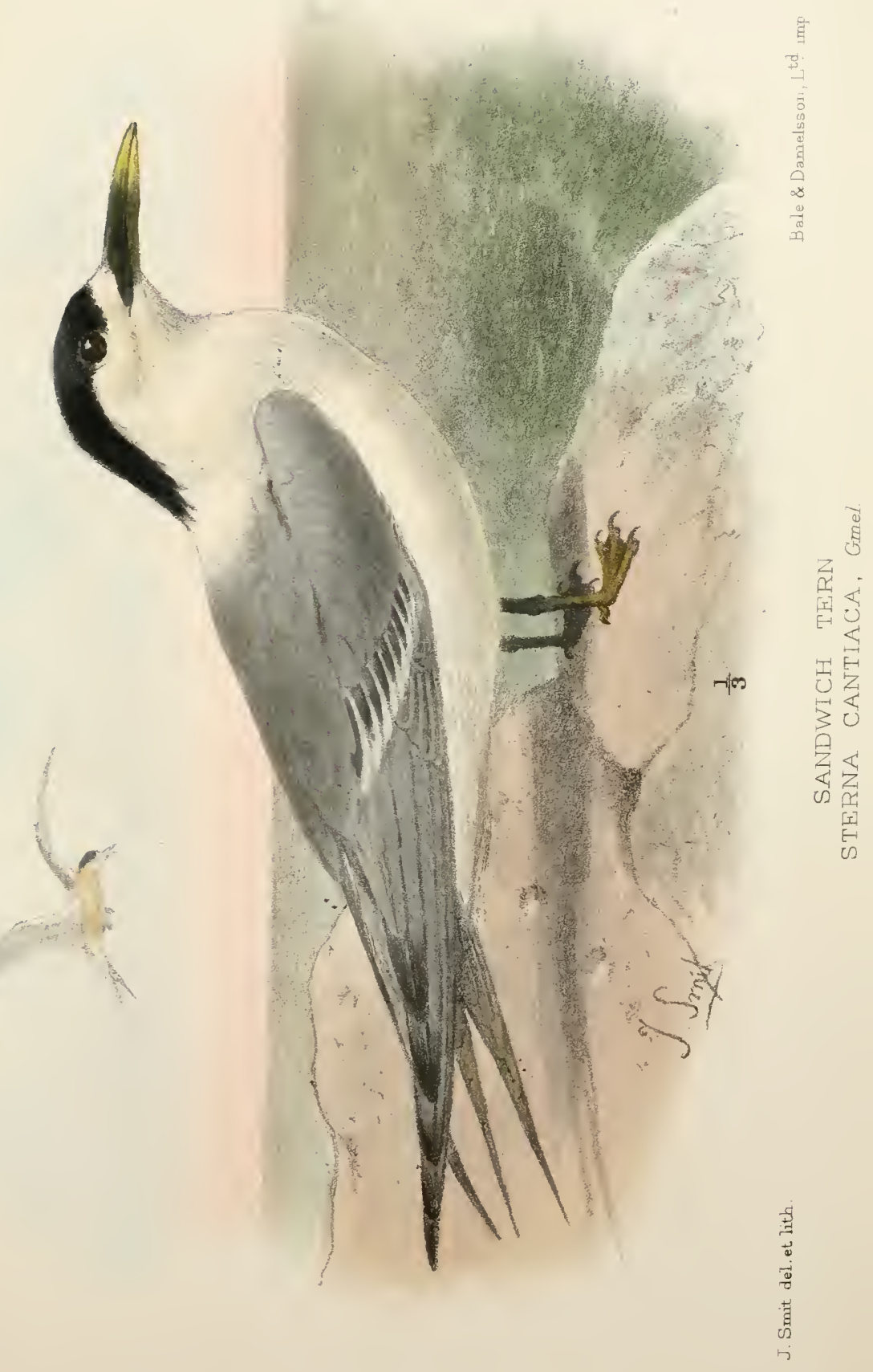



In 1896 Captain Boyd Alexander, in his notes from Romney Marsh, writes: "On May 23 I was fortunate enough to discover, with the aid of my field glasses, a pair of Sandwich 'Terns breeding here. The birds, however, deserted after the first egg was laid. I am inclined to think that the Common Tern must have driven them away."

Dr. F. Plomley found it breeding at Dungeness.

\section{Genus HYDROCHELIDON, Boie.}

\section{BLACK TERN.}

Hydrochetidon nigra (Linnæus). S.N., i., p. 227 (1766).

In the early part of the last century the Black Tern was very abundant in the marshy lands of Kent, and especially in Romney Marsh, where it used to breed in colonies, but at the present day a pair or so make their appearance in summer, but do not remain to breed.

Montagu found it breeding in Romney Narsh before 1802. Writing in 1844, the Rev. J. Pemberton Bartlett states that it was "common, breeding in Romney Marsh."

Mr. W. H. Power, in his Birds Observed at Rainham, 1865, writes: "On several occasions during the autumn I fancied that I had seen a few of these 'Terns, though at such a distance that it was impossible to identify them. At length, on October 12, during a gale from the northward, I observed one beating about some sheltered pools of water inside the sea-wall, it proved to be a bird of the year. This species is far from common about the creeks." In 1868 Mr. F. D. Power says: "It is never 
numerous at Rainham. A few appear about the creeks during September. Shot one, a bird of the year." Mr. W. Prentis, of Rainham, writes that "the Black Tern visits us in the month of August. Always immature."

A female of this species in the Maidstone Museum was obtained at Marden, in Kent, on September 11, 1884, by Mr. H. Kennard. Mr. C. Gordon, of Dover, obtained it in June, 1885, near that place.

In 1896 Captain Boyd Alexander says : "A parr of Black 'Terns were seen on May 24, following the seaboard in Romney Marsh."

\section{Genus RISSA, Stephens.}

\section{KITTIVAKE.}

Rissa tridactyla (Linnæus). S.N., i., p. 224 (1766).

Nearly all the year round the Kittiwake may be seen or obtained on the coast of Kent, in all stages of plumage. In the spring, and again in autumn, they become more plentiful during immigration and migration. It is at the latter period that many pass inland, or ascend the rivers and are found on the large mud-flats and pastures, occasionally being driven inland by gales and severe weather. There are no suitable rocky cliffs on the coast for a bird L. : nd in Kent.

There is a good series in various stages of plumage in the Maidstone Museum, from the Lower Medway, obtained by Mr. R. J. Balston.

For the last few years these birds have come up the Medway as far as Springfield, Maidstone. This year, 1907, they arrived by the middle of Angust, which I think is earlier than usual.-R. J. Balston. 


\section{Genus LARUS, Linnæus.}

\section{GLAUCOUS GULL.}

Larus glaucus, Fabricius. Faun. Grenl., p. 100 (1780).

This large and fine Gull is a rare and only a winter visitor to the coast of Kent, and few examples are recorded.

The Rev. J. Pemberton Bartlett, in 1844, says that "Dr. F. Plomley has obtained a specimen of this bird in Romney Marsh. Several of the Glaucous Gulls have been seen this summer (18t4) in the Marsh. Hitherto Dr. F. Plomley has been unable to procure any of them."

Mr. D. H. Fry, writing on December 16, 1846, says: "Whilst staying a few days at Ramsgate, I saw two examples of young Glancous Gulls, one of which I succeeded in shooting. The occurrence of this description of Gull is by no means common in this part of the country."

\section{HERRING GULI.}

Larus argentatus, Gmelin. S.N., i., p. 600 (1788).

The Herring Gull is one of the most abundant species, at all times of the year along the coast of Kent, and may be seen in every stage of plumage. There is only one suitable part of the coast on which the Herring Gull is found to breed, which is well described by Colonel H. W. Fielden, in 1887. He writes: "Cliff-birds at Dover. During the first week of July the fine chalk cliffs between Dover, the South Foreland, and St. Margaret's Bay present a very animated appearance. Hundreds of Her- 
ling Gulls are nesting there, and the young ones may be seen about their nests, attended by the parent birds. For some reason or other-probably for the want of suitable ledges-the Herring Gulls do not appear to nest on the abrupt faces of the cliffs, but in spots where landslips have occurred, and where slopes more or less covered with verdure, but of a very steep incline, have formed amid the cliffs. In selecting such breeding places the Herring Gulls have, as might be expected, selected the more inaccessible slopes, and as far as I could judge, walking below the cliffs, I did not notice any occupied nestingplaces that an ordinary rock-climber would attempt, withont the aid of a rope from above. Great mortality occurs amongst the young Gulls from the nests being placed on these steep inclines, for the young, tempted from their nests, lose their foothold on the slippery grass, and slide and fall on to the beach below, where they are abandoned by the parent birds. In the first week in July of this year (1887), my companion and I counted over fifty dead young ones in the course of our walk along the base of the cliffs, and we saw two young Herring Gulls lose their foothold and come down, trying to save themselves with expanded feet and their little apologies of wings extended; they reached the beach in safety, where we secured them, took them home, and they are now flourishing in my companion's garden. There is, however, one exception to the general rule of these gulls breeding on the cliff-slopes, and that is a few pairs making their nests on the gravel beach at the base of the cliffs, just above the line of ordinary high water. The spots available are very few and restricted in area, and as they can be reached at low tide, these nests are invariably plundered of the eggs. My com- 
panion informed me that during the past seven years he had on several occasions talien eggs from their nests on the shore. He is inclined to think that the very great increase in the numbers of the Herring Gulls since the Wild Birds Preservation Act came into force has led to the crowding of the securer breeding stations, and that the Gulls that nest on the beach are the younger ones which have been unable to find nesting room in the safer positions. It was satisfactory to learn, from my companion's personal observation, that the number of Herring Gulls had largely increased during the past ten years. I should estimate roughly that not less than four hundred pairs of Herring Gulls nest in the cliffs between Dover and St. Margaret's Bay. To ornithologists who reside in the neighbourhood of Isondon, and who may not have the opportunity of visiting the more distant great rock nurseries of sea-fowl along our coasts, I recommend a visit to these cliffs, but care must be taken to time it with due consideration of the tides, for a mistake might lead to an awkward predicament, as at high water the sea rises to the cliffs, except in a few spots, where some of the gulls, as I have already mentioned, make their nests on the gravel" (Zoologist, 1887, p. 294).

\section{YELLOW-LEGGED HERRING GULL.}

Larus cachinnans, Pallas. Zoogr. Russo-Asiat., ii., p. 318 (1818).

"The Hon. N. Charles Rothschild records that he observed in Dover Harbour, on April 18, 1904, a bird which he considered to have been an example of the Yellow-Legged Herring Gull (Larus cachinnans). The 
bird in question was flying in company with sereral of the common Herring Gulls (Larus argentatus), and passed unusually close to the observers. The bird was noticed to have orange-coloured legs, not only by the recorder, but by his brother and the Hon. F. R. Henley" (Bulletin of the B.O.C., vol. xiv., p. 91, 1904).

\section{LESSER GREY GULL.}

Larus camı, Linnæus. S.N., i., p. 224 (1766).

\section{Winter Gull, Boys, 1792 ; Cobb or Sea Cobb.}

This pretty Gull is a regular spring and autumn visitor to Kient. They generally remain all the winter along the coast. During the open weather they may be seen in large numbers in the marshes, on the ploughed land, and even following the plough in flocks; they go far inland in search of freshly turned-up fields.

On October 23, 1905, at the top of the hills overlooking Romney Marsh, on the road to Lympne, a pair or two were flying overhead, and near the village a flock of over twenty were following a plough close to the road, and in the Marsh itself similar flocks were found acting in the same mauner. On other occasions, twos, threes and fours were nearly always to be found passing over close to the ground on the recently turned soil. 


\section{GREAT BLACK-BACKED GUTL.}

Larus marinus, Linnæus. S.N., i., p. 22.5 (1766).

Cobb; Wagell.

This fine large species may be considered a resident on the coast of Kent, being found at all times of the year, in pairs or singly. It is very rarely found inland, never leaving the sea-shore.

The following note appears in Yarrell's last edition of British Birds, viz. : "Dr. Turner, who wrote on British Ornithology more than three hundred years ago, calls this Gull a "Cob," and by this name it is still known on the flat shores of Kent and Essex, at the mouth of the Thames, where this bird remains all the year.

Boys, in his Birds of Sandwich, 1792, calls this bird the "Wagell." This name is applied to the full-grown young bird in the mottled plumage.

On February 8, 1906, during the great snow- and thunderstorm that passed over Kent on that day and did so much damage, Mr. Tims, of Ham Street, on returning along the Royal Military Canal in Romney Marsh, and about half-way between Ruckinge and Ham Street, came upon a pair of dead Great Black-backed Gulls lying close together, which was a most unusual instance of these birds being found so far inland. After a careful examination there was no doubt that they had been struck by lightning and killed close together. On the pinion of each bird it appeared as though it had been burnt, the blood-vessels had all been burst, and the contents in a watery condition diffused over the whole of the interior, but nowhere in clots. 


\section{LESSER BLACK-BACKED GULL.}

Lams fuscus, Linnæus. S.N., i., p. 225 (1766).

New or Sea-Mew.

On the coast of Kent this bird is one of the most numerous at all times of the year. The full-grown young in their grey-brown mottled plumage are the most imprudent of their race; with those of the young Herring-Gulls, they appear to have lost all fear, approaching, as they do, close to the habitations of man, seeking whatever may be thrown from the house, especially from those cottages near the sea.

Writing in 1865, Mr. W. H. Power says: "I observed adult birds of this species early in July. They are, next to the Black-headed, the most common Gull about the creeks of Rainham; as many as fourteen have been seen together in one flock; they are, however, exceedingly wild, and it is seldom that one can get within gunshot of them. This, and every other species of Gull about the size of the Black-headed Gull, is in this neighbourhood called a "Cob."

\section{BLACK-HEADED GULL.}

Larus ridibundus, Linnæus. S.N., i., p. 225 (1766).

Crock or Crocker.

From ages past the beautiful rosy-breasted Blackheaded Gulls have had a colony or two during the summer months in Romney Marsh. Although greatly diminished of late years (by the plunder of their eggs), 
they still persist in holding that particular breeding place. After the breeding season they become spread over the land, especially on that part under the plough.

In Mr. W. H. Power's Birds Observed at Rainham, 1865, he writes: "These Gulls left this year for their breeding grounds about the end of February; a few had returned by July 1 ; these were mostly adult birds, still retaining the brown head. By far the greater number did not make their appearance until the end of July and beginning of August; at this time they collect into flocks, which consist chiefly of birds of the year, a few old ones only (and these without the brown head), to be found among them. This species, which is by far the most common about the creels, continues in the neighbourhood during the whole winter, occasionally visiting the "sprat-fields" on the cultivated land, where, in company with the Hooded Crow, it enjoys a most savoury banquet. It is astonishing how correctly they time themselves in their visits inland, generally leaving the creeks as soon as the rising tide has covered the mud-banks; from this time till the turn of the tide not a Gull is, as a rule, to be seen; but no sooner does the tide begin to ebb than they reappear, first in ones and twos, then in detached parties, and immediately commence beating over and settling on the mud-flats, now covered by only an inch or two of water."

Mr. F. D. Power, writing from Rainham in 1868, says: "September 29: My brother killed two splendid adult birds, both having, in addition to the roseate breast, a most beantiful rosy-pink hue on the four outer quills of each wing, most marked on the shafts. Specimens with roseate breasts we have not infrequently met with here in winter, but until now had not come across any 
with such a colour on the wings. The general effect was extremely beautiful."

In 1896 Captain Boyd Alexander, in his notes from Romney Marsh, writes: "On June 4 I made an expedition to the Hoppen "Petts," for the purpose of inspecting the colony of Black-headed Gulls. The "Petts," which lie about four miles south-east of Lydd, consist of two large pieces of water of unknown depth. They are, furthermore, fringed with treacherous reedbeds which possess all the qualities of a dangerous bog. They are also the home of many leeches. When within a mile of these "Petts" I could discern a number of Black-headed Gulls lining the banks, and looking like so many lumps of white chalk. On a nearer approach they all rose up, full of clamorons consternation-a veritable sea rookery-and circled above the water. They numbered about 200, and at least a quarter of these wore the dress of immaturity. I discovered over twenty nests, all containing eggs, with the exception of two which had young. These nests were invariably placed close to the edge of the reed-bed nearest the water. On one small "reedy" promontory there were no fewer than eight, situated hardly a yard apart. Of late years this colony of Gulls has suffered much persecution, but the owner, Mr. Samson, of Lydd, exercises now a strict surveillance over it, with the result, I am glad to say, that the colony is rallying." 


\section{LITTLE GULL.}

Larus minutus, Pallas. Reise Russ. Reichs., iii.,

$$
\text { App., p. } 702 \text { (1776). }
$$

It appears from the records of the occurrences of the Little Gull in Kient, that it may be more often met with than is supposed. The bird, in its immature or winter dress during autumn, may escape observation when among Terns and the Black-headed Gull in winter dress.

Morris, in his History of British Birds, states that "one was obtained at Sheerness into 1840."

Writing on March 7, 1862, Mr. W. Oxenden Hammond says: "Two Little Gulls were obtained for me on the Kentish coast last month (April); one was a bird of the first year, the other a very fine adult; they had far advanced towards the summer state of plumage."

Mr. G. B. Ashmead writes, October 6, 1868: "From amongst a lot of Gulls, \&c., shot for me a little below Gravesend, I have found a fine adult specimen of the Little Gull in winter plumage. This comparatively scarce species of Larus was observed in company with the Common Tern."

Mr. W. Prentis records having obtained one in Rainham Marsh on "February 1, 1870, and in March he observed another with a black head. On February 14, 1874, an adult Little Gull was shot at the mouth of Milton Creek. On September 17, 1884, a young immature Little Gull was shot on the Medway, in mottled plumage."

In 1893, Mr. W. O. Hammond writes: "On January 19 I received a Little Gull (Larus minutus) from a 
fisherman who sends me anything he gets that he thinks worth having. This species has occurred not infrequently on this coast (Kent). It is probably worth recording the circumstance of its having the beautiful roseate colour of the under-parts, which I should hardly have expected in mid-winter."

In 1898 Captain Boyd Alexander records that "on March 3, near Horsemonden, a fine adult male Larus minutus was obtained. Horsemonden is about 12 miles, as the Crow flies, from the River Rother."

\section{BONAPARTE'S GULL.}

Larus philadelphia (Ord). Guthrie's Georgr., 2nd Amer. Ed., ii., p. 319 (1815).

Mr. G. Dowker, in his Birds of East Kent, says: "This interesting addition to our Fauna, I have on the authority of Lord Clifton, of Dumpton, Thanet, Kent, who writes: 'There can be no reasonable doubt as to Bonaparte's Gull. A notice of this bird appears in the Field, April 4, 1888.' It is not mentioned in Harting's Handbook, 1901."

\section{Genus STERCORARIUS, Brisson.}

\section{GREAT SKUA.}

Stercorarius catarrhactes (Linnæus). S.N., i.,

$$
\text { p. } 226 \text { (1766). }
$$

The Rev. J. Pemberton Bartlett, writing in 1844, states that Dr'. F. Plomley says : "I seldom ride along the coast without seeing one or two specimens. They are the most difficult of all Gulls to kill." 
Mr. R. J. Balston has seen the Great Skua off the coast of Kent and in the estuary of the Thames.

In 1901 Mr. IV. R. Butterfield, in writing to the Zoologist, p. 521, states that " a female Great Skua was shot on October 4 near the Post-office at Dungeness, by Mrr. G. Bates, and forwarded to me in the flesh." This specimen is now in the Museum at Hastings.

\section{POMATORHINE SKUA.}

Stercorarius pomatorthimus (Temminck).

$$
\text { Man. d'Ornith., p. } 514 \text { (1815). }
$$

In the last edition of Yarrell's British Birds it is stated that "the first notice of this species as a British bird appears to be in the sale catalogue of Mr. Bullock's collection, April, 1819, where at p. 32, lot 62, a second example of this same species, killed at Dover," is mentioned.

Although the Rev. J. Pemberton Bartlett, in 1844, states that this species is "not uncommon in Romney Marsh," there are no records of its occurrence in that locality. There is a Kentish specimen in the Maidstone Museum, presented by Mr. G. Simmons, which may be out of the Marsh. He had several birds from that locality.

In $1868 \mathrm{Mr}$. F. D. Power, in his notes from Rainham, says: "Two were shot in this district during September, one in the immediate neighbourhood at the beginning of the month, and the other at Stangate Creek on the 28th. This last was a very nice specimen of the Pomerine Skta, and, according to Yarrell, in the 
plumage of the second year. It was chasing T'erns when first seen, and proved tame, allowing a near approach in a boat as it sat on the water. The other bird appears to have been also of this species."

In 1869 Mr. J. Hunter, of Faversham, says: "A specimen of the Pomerine Skua in fine plumage was shot on this coast on November 14, and is now in my collection. The bird is an immature female and answers very closely to Yarrell's description, excepting in the colour of the bill, cere and legs, which latter, in my specimen, is a clear challi-blue, and the base of the bill and cere greenishwhite; nearly the whole of the fore-toes and webs are black, but the hind toe and claw are the same colour as the legs."

Mr. WV. Prentis records "a pair of Pomerine Sliuas, which were shot by a bargeman when in the act of killing a Common Gull beyond Rochester Bridge on February 20, 1882, one a fine adult with yellow collar and a long turned-up tail, the other immature in the brown plumage; and another was shot flying over Chatham Hill in windy meather, November 27, 1890, either in the second or third year's plumage."

In 1898 Mr. G. Slaney presented to the Maidstone Museum an immature bird. It was killed at Salt Pan, near Sandwich, Kent, on October 18, 1898. 


\section{RICHARDSON'S SKUA.}

Stercorarius crepitatus (Gmelin). S.N., i., p. 602 (1788).

Richardson's Skua is more often seen on the coast of Kent than obtained. It is a winter visitor to the shores of the county and ascends the River Thames, keeping generally to the estuaries.

Morris states that "in the winter of 1800 one was shot at Greenwich, another at Sandwich." From this period, strange to say, until 1863 , nothing appears to have been noticed of this bird.

Mr. E. Young, of Sittingbourne, writing on July 1, 1863, says: "I had a beartiful specimen of this bird brought me this morning." In 1867 Mr. A. H. Smee says: "On October 3 I saw two specimens of the Common Slina, the first just opposite Greenhithe, the other by the Chapman Light. The latter when observed was chasing a Common Gull, which it soon compelled to disgorge its food."

A specimen in the Maidstone Museum was killed by Mr. H. Payne, October 17, 1895, at Stoke, Kent. A young or immature bird in the British Museum was obtained at Gravesend in Septomber.

$\mathrm{Mr}$. W. Prentis mentions that "the mature bird with a long tail is extremely scarce, one was shot out of the bounds of my district, October, 1865, on the Swale River."

Mr. R. J. Balston also observed it in the mouth of the Medway. 


\section{Family PROCELLARIIDÆ,}

Genus PROCELLARIA, Linnæus.

STORM-PETREI.

Procellaria pelagica, Limmeus. S.N., i., p. 212 (1766).

Storm Finch.

This curious little bird is often beaten on to the coast of Kent during heavy weather. Boys mentions an instance at Margate in 1792.

The Rev. J. Pemberton Bartlett, in 1844, says: "These ill-omened birds are sometimes to be seen on the lientish coast in stormy weather. I once observed several from the pier at Dover. The 'Mother Carey's Chickens,' or 'Spencies,' as they are called by sailors, are interesting birds, not only from the superstition which attaches to them, of causing storms and shipwrecks, but also from their swiftness of flight, and the apparent ease with which they fly inmense distances."

Mr. W. Prentis mentions that a shepherd boy picked up a Stormy Petrel alive near Rainham.

\section{RIDGWAY'S PETREL.}

Procellaria cryptolencura (Ridgway). Proc.U.S. Nat. Mus., iv., p. 337 (1882).

The particulars respecting this bird, which was found in Kent, are taken from Captain Boyd Alexander's notes in the Zoologist (1896, pp. 167-68): "An example of Oceanodroma cryptolencura, which proved, on dissection, 
to be a female, was picked up on the beach close to Littlestone, a small village 6 miles north of Dungeness, on December 5 (1895) last, at a time when strong northwesterly gales were prevalent. It was taken the next day to Mr. Bristow, at St. Leonards, and there I saw it in the flesh. It was in poor condition, and clearly, in appearance, a storm-beaten victim. This specimen was subsequently exhibited by Mr. Howard Saunders at a meeting of the British Ornithologists' Club, on April 15, and the fact that it was found on the English Coast will be of interest to ornithologists, not only because it adds a fresh species to the British Procellariida, but also on account of the recent discovery by Mr. Ogilvie Grant of the breeding of this species in the Canary seas, where it had been previonsly confounded with Leach's Fork-tailed Petrel." A second specimen was exhibited by Dr. N. F. Ticehurst at a meeting of the British Ornithologists' Club, held on November 21, 1906, "which had been obtained near Hythe, in Kent, on November 8, 1906. On dissection it proved to be a female. The bird was shot while flitting along the shore in a tired manner after the subsidence of the heavy south-west gale that blew in the Channel from November 4 to $8 . "$

\section{LEACH'S PETREL.}

Procellaria lencorrhoa, Vieillot. Nour. Dict., xxv., p. 422 (1817).

Fork-tailed Petrel.

In 1844 the Rev. J. Pemberton Bartlett mentions that Dr. F. Plomley obtained a specimen of this rare bird. 
Captain H. IV. Hadfield, writing from Tonbridge on January 6, 18.57, says: "I have lately seen in this town a very fair specimen of this Petrel, which was, I am informed, found dead some three or four years since at Peckham in this rieighbourhood."

In 1868 Mr. J. Hunter, of Faversham, in Kent, says: "A specimen of the Fork-tailed Petrel was shot near here on October 3."

A male specimen in the Maidstone Museum was picked up alive in Mill Street, in that town, on November 27, 1881.

\section{Genus PUFFINUS, Brisson.}

\section{GREAT SHEARWATER.}

Puffinus major, Faber. Prodr. isl. Orn., p. 56 (1822).

This Shearwater is only an occasional visitor to the coast of Kent.

In $1891 \mathrm{Mr} . J$. H. Gurney records that " on October 29, 1890, an adult male Great Shearwater (Puffinus major) was found alive by a boy on the rocks at Ramsgate. This bird was taken to Mr. Softley, who, by feeding it on fish, kept it alive until May 9 (more than six months), hoping it would lay an egg; a futile hope, as it proved to be a male." 


\section{MANX SHEARWATER.}

Puffimus anglorum (Temminck). Man. d'Orn., ii., p. 806 (1820).

This specics is more often found on the coast of Kent than the former. It comes into the estuaries and bays along the coast, generally in the autumn and winter.

Mr. G. Dowlier mentions it from Dover Bay. The Rev. C. H. Fielding states it has been obtained at Erith. Writing on October 21, 1862, Mr. H. L. Saxby says: "Yesterday afternoon I saw a specimen of the above in this harbour (Sheerness). It was sitting rather deeply in the water, and although making vigorous use of its feet, was being so rapidly carried backwards by the ebb tide and heavy south-west gale that it was occasionally compelled to take wing in order to avoid being drifted too close to the ships. It rose from the surface with very little effort, and had rather a graceful appearance when upon the wing, but its mode of flight was peculiar, owing to the bird's strange but well-known habit of making an occasional rapid stop, apparently with no other object than that of dashing aside the water with its breast, immediately afterwards ascending in a gentle curve. Although it was at times completely at the mercy of the wind and tide it seemed to be perfectly at ease, dipping and preening its feathers and sometimes rising upon its feet as it flapped the water from its wings. It proved to be a female in good condition." 


\section{LESSER DUSKY SHEARWATER.}

Puffinus assimitis, Gould. Proc. Zool. Soc., 1837, p. 156 ; Birds of Australia, vii., pl. 59 (1848).

Dr. N. F. Ticehurst exhibited, at a meeting of the British Ornithologists' Club, held on December 13, 1905, " a male specimen of the Lesser Dusky Shearwater (Puffinus assimilis) which had been caught alive by Mr. Wallis, of Lydd, Kent. It had been caught near that town after that disastrous south-west gale of November 26 to 27 , and kept alive for two days in a pool of water. When examined it was covered with sand and sodden with sea-water."

\section{Family COLYMBIDE.}

Genus COLYMBUS, Linnæus.

\section{GREAT NORTHERN DIVER.}

Colymbus glacialis, Linnæus. S.N., i., p. 221 (1766).

The specimens of this northern species which bave been procured on the coast of Kent are immature birds, taken during the winter, which have been driven down south by severe weather.

It is included in Boys' Birds of Sandwich, 1792. The Rev. J. Pemberton Bartlett, 1844, says: "This bird has been observed in Romney Marsh." There is a Kentish specimen in the Maidstone Museum presented by Major Best. Mr. G. Dowker says that it is " met with in severe weather, chiefly off Whitstable and the River Stour."

Mr. IV. Prentis also states that "immature birds are sometimes met with and shot on the Medway." 


\section{BLACK-THROATED DIVER.}

Colymbus arcticus, Linnæus. S.N., i., p. 221 (1766).

Like the former species, a winter visitor, and most of them immature birds.

Morris mentions that "one was killed near Sittingbourne in Tient in 1840, recorded by Mr. Chaffey."

In the last edition of Yarrell's British Birds it is stated that "Mr. S. Mummery, of Margate, sent the author" notice that a beautiful specimen was captured June 2, 1842, in Sandwich Haven, and this, being a fine male bird, was preserved, and deposited in the Museum at Margate." The Rev. J. Pemberton Bartlett, 1844, says "it has also been seen in Romney Marsh."

The Rev. C. H. Fielding records it from Erith in 1850 and Upchurch in 1888. There is a specimen in the Maidstone Museum, obtained in the Medway by $\mathrm{Mr}$. IV. H. Bensted.

Mrr. G. Dowker mentions it from various localities on the coast, and Mr. WV. Prentis also.

\section{RED-THROATED DIVER.}

Colymbus septentrionalis, Linnæus. S.N., i, p. 220 (1766).

\section{Sprat Loon ; Silver Grebe.}

The Red-throated Diver is the most numerous species on the coast of Kent during the autumn and winter, where it may be found in the estuaries, especially along the shore, following the shoals of sprats. From the above 
habit it is commonly called the Sprat Loon in Fent. It is very rarely procured on this coast in full dress; they are usually immature birds, but Mr. Skinner, of Faversham, mentions one shot on November 11, 1869, with indications of the red throat.

Mr. H. Payne obtained a male on the Medway, near Sheerness, December 5, 1890, now in the Maidstone Museum.

Family PODICIPIDÆ.

Genus PODICIPES, Limneus.

\section{GREAT CRESTED GREBE.}

Podicipes cristatus (Limnæus). S.N., i., p. 222 (1766).

The Great Crested Grebe is a winter visitor to the coast of Kent, and only sparingly in any locality. They are always in winter or immature dress. It is included in every list of the birds found in the county, and nearly all collections contain specimens. Boys adds it to his Birds of Sandwich, 1792. The Rev. J. Pemberton Bartlett, in 1814, says " it has been seen in Romney Marsh."

A specimen in the Maidstone Museum was obtained on the Medway in 1876, by Mr. W. W. Allport, and another at Sheerness, November 19, 1890, by Mrr. H. Payne. Mr. R. G. Roger procured one which was caught on the Royal Military Canal in Romney Marsh not far from Ham Street, Orlestone, Tient, in 1905.

Mr. R. J. Balston shot one of these birds in the lower part of the Medway about 1880 . 


\section{RED-NECKED GREBE.}

Podicipes griseigena (Boddaert). Tabl. des Pl.

$$
\text { Ent., p. } 55 \text { (1783). }
$$

An occasional visitor during autumn and spring. They are in winter and immature plumage, rarely found in full dress.

Mr. W. F. W. Bird records that "on February 6, 1849, my friend, Mr. James Moore, from his yacht, killed a Red-necked Grebe in Stangate Creek, near the mouth of the Medway. It was a bird of last year, and was just beginning to assume the adult plumage."

\section{SCLAVONIAN GREBE.}

Podicipes auritus (Limnæus). S.N., i., p. 222 (1766).

This species is more usually met with in winter in the estuaries of Kent than either of the former Grebes. They are always in autumn or immature dress.

Boys includes it in his Birds of Sandwich, 1792, under the name of "Less Crested Grebe."

In $1869 \mathrm{Mr}$. A. Skinner writes: "Two of these birds were shot three miles from Faversham, on December 13. One of these I received on the 14 th ; it was an adult male, in winter plumage. I was informed by the man who shot them that there were several of them together." Mr. G. Dorvker says: "this bird was shot near Stourmouth in January, 1885"; and Mr. W. Prentis records it from the Rainham marshes.

On November 11, 1906, a young Podicipes auritus was shot on the Medway between Gillingham and Sheerness, by Mr. H. Payne, and is now in the Maidstone Museum; another was obtained by Mr. R. J. Balston. 


\section{EARED GREBE.}

Podicipes nigricollis (C. L. Brehm). Vög. Deutschl., p. 963 (1831).

This pretty Grebe is comparatively rare on the coast of Kent, and being only a winter visitor it may be often mistaken for the young of the Sclavonian Grebe.

Mr. G. Dowker writes: "I met with the Eared Grebe in February, 1875; it was caught in a duck pond near the yard at North Court, Stourmouth, and brought to me alive; it was a young bird. It is in the possession of Dr. Gulliver, of Canterbury." Mr. WV. Prentis says: "I have only known of a single pair of Eared Grebes being shot in the Rainham district, both immature, in the month of September, 1881. Mr. G. W. Bradshaw, of Hastings, writes: "On November 14, 1896, I had brought to me a male Eared Grebe shot on the sea about a mile east of Dungeness, Kent. Weight 9 ounces; contents of gizzard, a little moss ; eye, yellow."

A specimen in the Maidstone Museum was obtained on December 15, 1899, at Shaftleet Marsh, Kent, by Mr. H. Payne.

\section{LITTLE GREBE.}

Podicipes fluviatilis (Tunstall). Orn. Brit., p. 3 (1771).

Dabchick.

This small Grebe is the best known of the species in Kent, especially under the name Dabchick. It is found in nearly all the swampy marshes and reed-bound lakes 
and ponds, where it breeds. A great many remain all the year, but during very severe weather they leave the frozen lakes, and increase again in numbers in summer and the breeding season.

Mr. R. T. Filmer says they are to be found in the large reed-beds near Fairfield Church, in Romney Marsh.

Mr. T. Hepburn, in his notes on the birds on the beach at Dungeness, says: May 10 to 14, 1900: "Little Grebe breeding in considerable numbers in the ditches and pieces of water on the marshland. I found nests with fresh eggs and eggs just hatching ont on May 13."

\section{Family ALCIDE.}

\section{Genus ALCA, Linnæus.}

\section{RAZORBILL.}

Alca torda, Linnæus. S.N., i., p. 210 (1766).

Auk.

The Razorbill is an occasional winter visitor to the shores and estuaries of Kent. They generally keep out at sea, but are driven in during north-easterly gales. Boys adds this species to his Birds of Sandwich, 1792, under the name of "Auk."

Mr. R. J. Balston shot a solitary bird in the Medway, off Okeham Ness, on December 8, 1886, and on the 18th he shot one of a pair in the Thames in Sea Reach. Mr. G. Dowker obtained it at Stourmouth. It has been obtained at many places along the coast. 


\section{Genus LOMVIA, Brandt. GUILLENIO'T.}

Lomvia troite (Linnæus). S.N., i., p. 220 (1766).

During the summer and breeding season the Guillemot is very numerous on the coast of Kent, but it is also found all through the winter, though in diminished numbers, by its migration south.

There is a colony of these birds at St. Margaret's Bay, which is thus described by Mr. J. Briggs: "St. Margaret's Bay is situated perhaps four miles from Dover, near the South Foreland Lighthouse, on the Kentish Coast. It is buried in a deep recess between high and prominent chalk cliffs, and contains a few houses, occupied chiefly by fishermen and the coastguard stationed there for the prevention of smuggling. During the month of Nay, in the present year (1852), I paid a visit to this remarkable spot and picked up the following gleanings in Natural History:-

"On the most inaccessible parts of the cliffs, overlooking the sea, between St. Margaret's and Dover, I found the Guillemot breeding; but I was told that this bird existed there in much more limited numbers now than formerly. The eggs were found resting lightly on the shelves of the cliffs, without nests; and I can bear testimony to the truth of the assertions which naturalists have made, that the eggs of this bird vary greatly both in ground-colour and markings. Of the three which I was able to procure, one had its ground-colour greenishwhite, and its broad end banded with a ring of deep 
black blotches, its sides varied with a few spots, but none at the smaller end. Another egg had a large black blotch on the centre of the broad end, from which diverged numerous spots, which became smaller in size as they approached the narrow end; ground-colour white. A third had some well-defined but irregularly shaped black spots scattered over it upon a greenish-white ground. These eggs were procured on May 26, 1852, and incubation had just commenced."

Writing in 1868, Mr. J. Hunter says that a "Guillemot was shot on November 9, at Faversham Creek, fully two miles from the open sea." There is a male in the Maidstone Museum which was picked up after a storm on Boxley Hill, on November 16, 1884, by Mr. A. F. Style.

Colonel H. W. Fielden, in 1887, writes: "A visitor to the cliff immediately below the South Foreland Lighthouses will be further gratified by finding that a considerable colony of Guillemots make it their breeding-station. It is a very bold, perpendicular headland, and I should consider it to be only accessible to experienced cragsmen with proper appliances. To stand below this cliff and watch the Guillemots shoot down from their lofty ledges to the sea is a very pretty sight. My eye could not discern any movement in their wings; the feet stretched out behind seemed to be the guiding power. I picked up one little downy black young one at the base of the cliff, which shows that the Guillemots breed there." 
Genus URIA, Brisson.

\section{BLACK GUILLENOT.}

Uria grylle (Linnæus). S.N., i., p. 220 (1766).

A rare occasional visitor to the coast of Kent. The Rev. J. Pemberton Bartlett, writing in 1844, says: "Of this very rare bird one specimen has been obtained in the parish of Lydd, and is now in Dr. F. Plomley's collection."

Mr. G. Dowker records that a "young bird was met with by Mrr. WV. Oxenden Hammond."

Genus MERGULUS, Vieillot.

\section{LITTLE AUK.}

Mergulus alle (Linnæus). S.N., i., p. 211 (1766).

During heavy north-easterly gales in winter the Little Auk is driven on to the coast of Kent, and on sereral occasions it has been found far inland. It is only an accidental visitor to the county.

Boys includes it in his Birds of Sandwich, 1792. Morris states that "one was shot near Dover" in 1840, and many were off the coast in 1841."

Mr. C. Gordon, writing on November 24, 1870, says: "A Little Auk was taken last week. Its capture was very singular. A party fishing saw the bird close to the boat, and on throwing the bait for fishing the bird tried to seize it; the party then threw a bait again towards 
the bird, and succeeded in bringing it to the boat's side, and then caught it with the hand."

Captain J. D. Cameron writes that a Little Auk, found at Bethersden, was brought to him.

On December 28, 1878, Mr. R. J. Balston secured a Little Auk which was captured on one of the ponds at Boxley Abbey, in Kent. It was a male bird, and is now in the Maidstone Museum.

\section{Genus Fratercula, Brisson.}

\section{PUFFIN.}

Fratercula arctica (Linnæus). S.N., i., p. 211 (1766).

\section{Willock.}

The Puffin, like most of the northern sea-birds, is driven on to the coast of Kent in severe weather, but only as an accidental visitor.

Boys includes it in his Birds of Sandwich, 1792. The Rev. J. Pemberton Bartlett, in 184t, says: "These curious birds are occasionally to be found in the cliffs in the neighbourhood of Dover."

Mr. Riley Fortune writes: "I have in my collection a specimen of the Puftin, which was shot on the Thames between Erith and Gravesend, on June 12, 1885."

Mr. W. Prentis says: "A storm-driven Puftin was picked up dead on our Rainham marsh after the November gale of $1893 . "$

A young bird of the year was picked up on Blue Bell Hill, above Aylesford, Kent, in October, 1905, and is now in the Maidstone Museum. 


\section{N D E X.}

A

Aberdeviue, Siskin, 160

Accentor modularis, 91

Accipiter nisus, 290

Acredula caudata, 95

"rosca, 95

Acroccphalus aquaticus, 86

$$
\begin{array}{ll}
, & \text { palustris, } 82 \\
, & \text { phragmitis, } 87 \\
, & \text { streperus, } 79 \\
, & \text { turdoidcs, } 83,84,85
\end{array}
$$

Agialitis cantiana, 376

$$
\text { , hiaticula, } 380
$$

Agelaus phoniceus, 206

Alauda arborea, 227

" arvensis, 225

" cristata, 228

Alaudida, Family, 225

Alca torda, 451

Alcedo ispida, 254

Alcedinida, Family, 254

Alcida, Family, 451

Ampelida, Family, 137

Anpclis garrulus, 137, 140

Anas boschas, 332

Anatida, Family, 320

Anser albifrons, 322

, anser, 321

", brachyr 7 hynchus, 322

", segetum, 321

Anthus cervinus, 114

, obscurus, 117

", pretensis, 113, 118

,, richardi, 116

" rupestris, 118

, spipoletta, 118

, trivialis, 115
Aquila chrysaëtus, 287 Archibuteo lagopus, 284 Ardea alba, 311

, bubulcus, 311

", cinerca, 309

,, purpurea, 310

, ralloides, 311

Ardcide, Family, 309

Ardetta minuta, 312

Asio brachyotus, 272

,, otus, 271

Asionide, Family, 271

Astur palumbarins, 289

Athene passerina, 276

Auk, Little, 454

, Razorbill, 451

Avocet, 388

B

Bargauder, Sheldrake, 327

Bee-Eater, 257

Bernicla bernicla, 323

" canadensis, 324

, lencopsis, 323

Bittern, 313

,, American, 314

,. Little, 312

Blackbird, 13, 14, 15, 16

Blackcap, 57, 58-60

Bluethroat, Red-spotted, 38, 39

White-spotted, 37, 38

Botaurus lentiginosus, 314 ,, stellaris, 313

Brambling, 184

Bubo bubo, 276

Bullfinch, 190

Bunting, 197 
Bunting, Cirl, 200

, Corn, 197

, Lapland, 204

" Ortolan, 201

," Reed-, 202

,, Snow-, 205

, Tawny, 205

,, Yellow, 198

Bustard, Great, 366

, Little, 367

Butcher-Bird, Great, 128

, Red-backed Shrike, 132

Buteo buteo, 281

Buzzard, 281

,$\quad$ Houey-, 293
,$\quad$ Rough-legged, 284

\section{C}

Caccabis mufa, 353

Calandrclla brachydactyla, 230

Calcarius lapponicns, 201

Calidris arenaria, 406

Caprimulgide, Family, 237

Caprimulgus entopcens, 237

Carduelis carduclis, 159

Certhia familiaris, 157

Certriide, Family, 157

Chaffiuch, 180

Charadriide, Family, 372

Charadrius pluvialis, 374

Chaulelasmus streperus, 334

Chelidon urbica, 151

Chenalopex regyptiacus, 320

Chiffchaff, 69-72

Chough, 211

Chrysomitris spinus, 160

Ciconia ciconia, 315

" nigr $\alpha, 316$

Ciconiide, Family, 315

Cinclida, Family, 93

Cinclus aquaticus, 93

" cinclus, 93

Circus cernginosus, 277

, cineracers, 278

", cyancus, 278
Cobb, Great Black-backed Gull, 433

", or Sea-Cobb, Lesser Grey Gull, 432

Cobbler's Awl, Avocet, 388

Coccothraustes coccothranstes, 164

Clangula glancion, 310

Columba livia, 349

," anas, 345

", palumbus, 346

Columbide, Family, 346

Colymbidce, Family, 446

Colymbus arcticus, 447

,, glacialis, 446

,, septentrianalis, 477

Coot, 364

Coracias garraia, 256

Coraciidce, Fanily, 256

Cormorant, 306

Corvide, Family, 211

Corvus corax, 224

", comix, 218

" corone, 218

, frugilegus, 220

," monedula, 216

Cotile riparia, 155

Coturnix cotumix, 356

Courser, Cream-coloured, 372

Crake, Baillon's, 361

, Corn, 361

, Spotted, 360.

Crane, 365

Creeper, 157

Creeper, Tree, 157, 158

Crex crex, 361

Crock, or Crocker, Black-headed

Crossbill, 192 Gull, $43 \pm$

, Parrot, 196

,, Two-barred, 197

Crow, Black, or Crow, 218

" Carrion, 218

" Dun, 218

", Grey, 218

, Hooded, 218

" Kentish, 218

," Queenborough, 218

,, Red-legged, 211 
Crow, Royston, $21 \mathrm{~S}$

Cuckoo, 262

Cuckoo's Mate, 250

Cuculida, Family, 262

Cuculus canorus, 262

Curlew, 417

, Pigmy, 402

, Stone-, $36 \mathrm{~s}$

Cursorius gallicus, 372

Cyanecula succica, 38 , wolfi, 37, 38

Cygnus bewickii, 326

, cygnus. 325

" immutabilis, 325

" olor, 324

Cypselide, Family, 234

Cypselus apus, $23 \pm$

" melba, 237

D

Dabchick, Little Grebe, 450

Dafila acuta, 331

Daulias luscinia, 45

, phitomela, 44, 45

Daw, or Jackdaw, 216

Dendrocopus major, 246

$$
\text { ", minor, } 247
$$

Dicky Dunnocks, 91

Dipper, 93

,, Black-bellied, 93

Dishwasher, Peggy, 107

$$
\begin{array}{ll}
\text {, } & \text { Pied Wagtail, } 107 \\
\text {, } & \text { Yellow, } 111
\end{array}
$$

Diver, Black-throated, 447

,, Dun, Goosander, 344

, Great Northers, 446

, Magpie, $3 \pm 6$

,, Red-throated, $4 \pm 7$

Dotterel, 383

$$
\begin{array}{ll}
, & \text { Land, } 383 \\
, & \text { Ring, } 380
\end{array}
$$

Dove, Ring, 346

, Rock, 319

, Stock, 318

," Turtle, 349

Duck, Eider, 342
Duck, King, 342

, Long-tailed, 311

" Norillon, 310

, Red-crested, 338

", Tufted, 338

" Vild, 332

" IVhite-eyed, 340

", Wird Pochard, 339

Dunlin, 399

$\mathrm{E}$

Eagle, Golden, 287

, Sea, 287

, White-tailed, 287

Emberiza cirlus, 200

,, citrinella, 198

, hortulana, 201

, miliaria, 197

, schoniclus, 202

Erithacus rubccula, 40

Erne, White-tailed Eagle, 287

Eudromias morinellus, 383

\section{F}

Falco asalon, 299

, peregrinus, 295

„subbuteo, 298

Falcon, Hobby, 298

,Iceland, 294

,, Merlin, 299

, Peregrine, 295

, Red footed, 301

Falconide, Family, 277

Felt, Fieldfare, 10

Fieldfare, 10, 11, 12, 13

Finch, Storm, Storm Petrel, 442

Fire-crest, 67, 68

Flamingo, 319

Flycatcher, Pied, 142

Spotted, 140

Fratercula arctica, 455

Fringilla calebs, 180

, montifringilla, $18 \pm$

Fringillide, Family, 159

Fulica atra, 364

Fuligula forina, 339 
Fuligula fuligula, 339

, marila, 339

, rufina, 338

Furze-chat, 31

\section{G}

Gadwall, 334

Galley-bird, Green Woodpecker, 248

Gallinago gallinago, 395

¿, major, 395

Gallinula chloropus, 363

Gannet, 308

Garganey, 331

Garrulus glandarius, 214

Gecinus viridis, 248

Glareola melanoptera, 371

, pratincola, 371

Glarcolida, Family, 371

Goatsucker, 237

Godwit, Bar-tailed, 415

" Black-tailed, 416

, Common, 415

Goldcrest, 66, 67

Goldeneye, 340

Goldfinch, 159, 160

Goosander, 344

Goose, Barnacle-, 323

, Bean-, 321

,, Brent-, 323

, Canada, 321

" Clatter, Brent Goose, 323

, Coal Cormorant, 306

" Cole Shag, 307

," Crocker, Egyptian Goose, 323

, Egyptian, 320

, Grey Lag, 321

, Minute, 346

, Pink-footed, 322

, Solan, 308

, White-fronted, 322

Gowk, Cackoo, 262

Grebe, Eared, 450

, Great Crested, 448

, Little, 450

, Red-necked, 449
Grebe, Sclavonian, 449

"Silver, Red-throated Diver, 447

Greenfinch, 162

Greenshanks, 414

Grey-Bird, Song-Thrush, 5

Grey Pate, Linnet, 185

Grosbeak, Pine, 191

Grossbeak, Hawfinch, 164

Grouse, Black, 357

, Pallas's Sand-, 350

" Red, 357

Gruide, Family, 365

Grus grus, 365

Guillemot, 452

, Black, 454

Gull, Black-headed, 434

, Bonaparte's, 438

,, Glaucus, 429

, Great Black-backed, 433

„, Herring, 429

, Lesser Black-backed, 434

, , $\quad$ Grey Gull, 432

, Little, 437

, Yellow-legged Herring, 431

, Winter, 432

\section{$\mathrm{H}$}

Hamatopus ostralegus, 387

Hagister, Magpie, 215

Haliaëtus albicilla, 287

Hammer, Yellow, $19 \mathrm{~s}$

Harelda glacialis, 341

Harrier, Hen, 278

," Marsh, 277

" Montagu's, 278

Hawfinch, 164

Hawk, Blue, Merlin, 299

„, Gos-, 289

, Kestrel, 302

, Night, Thick knee, 368

, Sparrow, 290

Hedge-poker, 91

Hedge-Sparrow, 91

Helodromas ochropus, 408

Hern, Grey, Heron, 309 
Heron, 309

," Buff-backed, 311

,, Great White, 311

,, Night, 312

, Purple, 310

, Squacco, 311

Hierofalco islandıs, 291

Himantopus himantopus, 390

Hinundinide, Family, 143

Himudo rustica, 143

Hobby, 298

Hoopoe, 257

Hydrochelidon nigra, 427

Hypola is icterina, 76, 77

\section{I}

Ibis, Glossy, 319

Icterida, Family, 206

Iÿnx torquilla, 250

\section{J}

Jackdaw, 216

Jay, 214

Joe Ben, Great Titmouse, 96

Jolly, IVhite throat, 53,54

Joy, Jay, 214

K

Kate, Brambling, 184

Kestrel, 302

,Lesser, 301

Kingfisher, 254

Kip, Tern, 420

Kite, 292

Kittiwake, $42 S$

Knot, 401

\section{L}

Lagopus scoticus, 357

Laniide, Family, 123

Lanius collurio, 132

$$
\begin{aligned}
& \text { ", excubitor, 12s, } 129 \\
& \text {, major, } 131 \\
& \text {," minor, } 131 \\
& \text {,. nubicus, } 137 \\
& \text {,, pomeranus, } 134
\end{aligned}
$$

Lapwing, 384

Lark, Black, 231

, Crested, 228

, Dusky, Rock Pipit, 117

" Less Field, 113

,. Nib, Corn Bunting, 197

", Sea, Ringed Plover, 380

", Shore, 232

," , Rock Pipit, 117

"Short-toed, 230

,, Sky, 225

,, White-winged, 231

,, Wood, 227

Laride, Family 119

Larus argentatus, 429

, cachinnans, 431

" canus, 432

, fuscus, 434

, glaucus, 429

, marinus, 439

, minutus, 437

, philadelphia, 438

" ridibundus, $43 \pm$

Ligurinus chloris, 162

Limicola platyr.hyncha, 393

Limnocryptes gallinula, 398

Limosa agocephela, 416

, lapponica, 415

Linnet, 185

,, Grey, 185

, Mountain, 190

Linota cannabina, 135

,, flavirostris, 120

, linaria, 187

, rufescens, $18 s$

Locustella luscinioides, 71 "navia, 88

Lomvia troile, 452

Loon, Sprat, Red-throated Diver, 447

Loxia bifasciata, 197

, curvirostra, 192

, pityopsittacus, 196

\section{II}

Machetes pugnax, 405

Macrorhamphus griseus, 415 
Magpie, 215

,, galley-Bird, 246

Mallard, 332

Mareca penclope, 330

Martin, 151, 155

, House, 151

, Sand-, 155, 157

Mavis, Song-Thrush, 5

May Bird, Whimbrel, 416

Meggie, Whitethroat, 53, 55, 56

Melanocorypha sibivica, 231

Melizophilus undata, 61 yeltoniensis, 231

Merganser, Red-breasted, 345

Mergulus alle, 454

Mergus albellus, 346

" merganser, 344

, serrator, 345

Merlin, 299

Meropide, Family, 257

Merops apiaster, 257

New, or Sea Mew, Lesser Black-

Mrilvus milvus, 292 backed Gull, 434

IIimus polyglottus, 92

Mocking-bird, Northern, 92

Moor Hen, 363

Motacilla alba, 106

$\begin{array}{ll}" & \text { flava, } 110 \\ " & \text { lugubris, } 107 \\ " & \text { melanope, } 108 \\ " & \text { provincialis, } 64 \\ " & \text { raii, } 111 \\ " & \text { undata, } 64 \\ \text { " viridis, } 111\end{array}$

Motacillide, Family, 106

Muscicapa grisola, 140

, atricapilla, 142

Muscicapide, Family, 140

\section{$\mathrm{N}$}

Night-Hawk, 237

Nightingale, 45,52

$$
\text { ," } \quad \text { Greater, } 44
$$

Nightjar, 237
Nucifraga caryocatactes, 213

Numenius arquata, 417

, phropus, 416

Nutcracker, 213

Nuthatch, 103, 104, 105

Nyctala tengmalnit, 274

Nyctea scandiaca, 274

Nycticorax griseus, 312

Nyroca ferruginea, $3 \pm 0$

\section{$\mathrm{O}$}

Edemia nigra, 343

$$
\text { ,, fusca, } 344
$$

Edicnemus odicnemus, 368

Olive, Oyster-catcher, 387

Oriole, Golden, 118, 127

Oriolide, Family, 118

Oriolus galbula, 118, 119, 122, 127

Osprey, 305

Otidida, Family, 366

Otis tarda, 366

, tetrax, 367

Otocorys alpestris, 232

Owl, American Screech, 275

" Barn-, 268

" Brown, 273

, Eagle, 276

„ Eared, 271

" European Hawk-, 274

" Fern-, 237

"Ivy, 273

,, Little, 276

,, Long-eared, 271

, Mottled. 275

, Scop's, 275

,, Screecli-, 268

"Short-eared, 272

", Snowy, 274

," Tawny, 273

, Tengmalm's, 274

, White, 268

"Wood, 273

Ox-bird, Dunlin, 399

„ Sanderling, 406

Ox-eye, Great Titmouse, 96

Oyster-catcher, 387 


\section{P}

Pandion haliaëtus, 305

Pandle, Wigeon, 330

Panurida, Family, 94

Panurus biarmicus, 91

Parida, 95

Partridge, 355

," French, 359

, Red-legged, 383

Parus Uritannicus, 98

,, coruleus, 100, 101

, cristatus, 103

,, major, 96

", palustris, 99

Passer domesticus, 169

,, montana, 177

Pastor, Rose-coloured, 209

Pastor roseus, 209

Peewit, 381

Peggy White-throat, 53

Pelicanidee, Family, 306

Perdix perdix, 355

Pernis apirorus, 293

Petrel, Fork-tailed, 1.13

,, Leach's, 443

,, Ridgway's, 442

," Storm, 442

Petty-chaps, Greater, 62, 63

Phalacrocorax carbo, 306

Phalarope, Grey, 391 graculus, 307 , Red-necked, 390

Phalaropus fulicarius, 391

$$
\text { ," Thyperboreus, } 390
$$

Phasianide, Family, 352

Phasianus colchicus, 352

Pheasant, 352

Phanicoptcrida, Family, 319

Phcenicopterus roseus 319

Phylloscopus rufus, 69, 72

, sibilatrix, 75

, $\quad$ superciliosus, 69

, trochilus, 72

Pica pica, 215

Picide, Family, 245

Picus martius, 245

Pigeon-Fieldfare, 10

,, Wood, 316
Pinicola enucleator, 191

Pintail, 331

Pipit, Meadow, 113, 114

, Red-throated, 114

,, Richard's, 116

, Rock-, 117

, Tree-, 115, 116

, Vinous, 118

Platalca lcucorodia, 317

Plataleide, Family, 317

Hlectrophancs nivalis, 205

Plegadis falcinellus, 319

Plover, Golden, 374

, Green, 384

" Grey, 375

, Kentish, 376

, Norfolk, 368

, Ringed, 380

, Stone, 380

Pochard, 339

Podicipida, Family, 448

Podicipes auritus, 449

, cristatus, 448

, fluriatilis, 450

, griseigena, 449

, nigricollis, 450

Porzana bailloni, 361

, porzana, 360

Post-Bird, Spotted Flycatcher, 140

Pratincola rubetra, 28

,. rubicola, 31

Pratincole, Black-winged, 371

,, Collared, 371

Procellaria cryptoleucura, 442

, leucorrinoa, 443

, pelagica, 442

Procellariide, Family, 442

Pteroclide, Family, 350

Puffin, 455

Puffinus anglorum, 445

,, assimilis, 416

, major, 444

Purre, Dunlin, 399

Pyrrhocorax graculus, 211

Pyrrhula pyrrthula, 190

Quail, 365

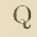


Querquedula circia, 334

crecca, 336

\section{$\mathrm{R}$}

Rail, Land-, 361

,. Water-, $35 \mathrm{~s}$

Rallide, Family, 358

Rallus aquaticus, 358

Raven, 224

Razorbill, 451

Recurvirostra avocetta, 388

Redbreast, 40, 41, 43

Redpoll, Lesser, 185

$$
\text { , Mealy, } 187
$$

Redshanks, 411

$$
\text { , Spotted, } 413
$$

Redstart, 33, 34, 35

$$
\text { , Black, 35, 36, } 37
$$

Redwing, 8, 9, 10, 12

Reeve, Ruff, 405

Regulus ignicapillus, 67

$$
\text { ," regulus, } 66
$$

Ring-Ouzel, 16, 18

Rissa tridactyla, 428

Robin, 40, 41-44

Roller, 256

Rook, 220

Ruff, 405

Ruticilla phcenicurus, 33

$$
\text { , titys, } 35
$$

\section{S}

Sanderling, 406

Sandpiper, 407

$$
\begin{aligned}
& \text { "Ash-coloured, } 404 \\
& \text {, Broad-billed, } 398 \\
& \text { ", Curlew, } 402 \\
& \text { ", Green, } 408 \\
& \text {, Greenwich, } 405 \\
& \text { ", Grey, Grey Plover, } 375 \\
& \text {, Pectoral, } 399 \\
& \text {, Purple, } 404 \\
& \text {,, Spotted, } 408 \\
& \text { "Wood, } 410
\end{aligned}
$$

Saxicola cenanthe, 23

$$
\text { "stapazina, } 28
$$

Scaup, 339

Scolopacide, Family, 385

Scolopax rusticola, 392

Scops asio, 275

$$
\text { , scops, } 275
$$

Scoter, Black, 343

$$
\text { , Velvet, } 344
$$

Screech-Owl, Swift, 234

Screecher, Swift, 234

Sea Pie, Oyster-catcher, 387

Serin, 162

Serinus scrinus, 162

Shag, 307

Sbearwater, Great, 444

$$
\text { ", } \quad \text { Lesser Dusky, } 446
$$

Sheldrake, 327

$$
\text { , Ruddy, } 329
$$

Shoveller, 337

Shrike, Ash-coloured, 128

$$
\begin{array}{ll}
\text {, } & \text { Great, 128, } 130 \\
\text { " } & \text { Lesser Grey, 128, } 129 \\
\text {, } & \text { IIasked, 137 } \\
\text {, } & \text { Pallas's Great Grey, } 131 \\
\text {, } & \text { Red backed, 132 } \\
\text {, } & \text { Woodchat, 131, 135, } 136
\end{array}
$$

Siskin, 160

Sitta casia, 103

Sittide, Family, 103

Skerrek, Little Tern, 422

Skua, Great, 438

$$
\text { , Pomatorhine, } 439
$$

"Richardson's. 441

Smew, 346

Snake-Bird, 250

Snipe, 395

$$
\begin{array}{ll}
\text { ", } & \text { Great, } 395 \\
\text {, } & \text { Jack, } 398 \\
\text { ", Jadreka, } 416 \\
\text { ", } & \text { Red-breasted, } 415 \\
\text { ", } & \text { Solitary, } 395 \\
\text { Summer, } 407
\end{array}
$$

Snow Flake, 205

Somateria mollissima, 342 , spectabilis, 342

Sparrow, Hedge-, 91, 92

$$
\text { , or House-Sparrow, } 169
$$


Sparrow, Reed-, 202

$$
\text { ,, Tree-, } 177
$$

Spatula clypeata, 337

Spoonbill, 317

Sprosser, Greater Nightingale, 45

Squatarola helvetica, 375

Squeaker, Swift, 234

Stare, or Starling, 207

Starling, 207

, Red-winged, 206

Stercorarius catarrhactes, 438

, crepidatus, 441

, pomatorhimus, 439

Sterna anglica, 425

, boysii, 426

, cantiaca, 126

" caspia, 425

,, dougalli, 422

, fluviatilis, 420

" $\quad$ rirundo, 419

,, minuta, 422

,, sandvicensis, 426

Stilt, Black-winged, 390

Stint, Little, 400

,, Temminck's, 401

Stonechat, 31, 32

Stone-runner, Ringed Plover, 380

Stork, Black, 316

, White, 315

Stormcock, Missel Thrush, 1

Strepsilas interpres, 386

Strigide, Family, 268

Strix flammea, 268

Sturnus vulgaris, 207

Sula bassana, 308

Surnia ulula, 274

Swallow, 143, 150

$$
\begin{array}{ll}
, & \text { Chimney, } 143 \\
, & \text { House, } 143 \\
, & \text { Sea, } 420
\end{array}
$$

Swan, Bervick's, 326

, Mute, 324

, Polish, 325

"Whooper, 325

Swift, 234

, Alpine, 237

" White-billed, 237

Sylvia atricapilla, 57
Sylvia curnuca, 55

" dartfordiensis,

, hippolais, 77

, hortcnsis, 62

, orphea, 56

", salicaria, 62

", sylvia, 53

Symium aluco, 273

Syrrhaptes paradoxus, 350

\section{$\mathrm{T}$}

Tadorna casarca, 329

, tadoma, 327

Teal, 336

Tern, 420

, Arctic, 419

", Black, 427

, Boys', 426

, Caspian, 425

, Gull-billed, 425

, Little, 422

, Roseate, 422

", Sandwich, 426

Tetrao tetrix, 357

Tetraonide, Family, 357

Thick-knee, 368

Throstle, Song.Thrush, 5, 7

Thrush, Missel, 1, 2

, Nisseltoe, 1

, Red-breasted, 20, 21

, Song-, 5, 6, 7, 8

," White's, 18, 19, 20

Timmunculus cenchris, 304

, tinnunculus, 302

", vespertinus, 301

Tit, Bottle, 95

Titlark, Meadow Pipit, 113

,, Tree Pipit, 115

Titmouse, Bearded, 94

, $\quad$ Blue, 100, 101, 102

, British Coal, 98

, , Long-tailed, 95

, Great, 96

, Crested, 103

," Marsh, 99

" White-headed Longtailed, 95 
'Tomtit, Blue 'Titmouse, 100

Tooke, Redshanks, 411

Totanus calidris, 111

, canescens, 414

"fuscus, 413

" glareola, 410

Tringa alpina, 399

$$
\begin{array}{ll}
, & \text { canutus } 404 \\
" & \text { grenovicensis, } 405 \\
", & \text { maculata, } 399 \\
" & \text { minuta, } 400 \\
" & \text { striata, } 404 \\
" & \text { subarquata, } 402 \\
, & \text { temmincti, } 401
\end{array}
$$

Tringoides hypoleucus, $40 T$ " macularius, 408

Troglodytes parulus, 105

Troglodytide, Family, 105

I'urtide, Family, 1

'I'urdus iliacus, 8

" merula, 13

" migratorius, 20, 21

", musicus, 5, 6

, pilaris, 10

, torquatus, 16

" varius, 18

" viscivorus, 1, 4

" whitci, 18, 19

Turnstone, 386

Turtur turtur, 349

Twite, 190

$$
\text { U }
$$

Upupa epops, 257

Upupide, Family, 257

Uria grylle, 454

$\mathrm{V}$

Tanellus vanellus, 384

\section{WV}

Wagell, Great Black-backed (iull, 433

Wagtail, Blue headed Yellow, 110

$$
\begin{array}{ll}
\text { ", } & \text { Grey, } 108 \\
, & \text { Grey-headed Yellow, } 111 \\
\text { ", } & \text { Prey Water, 108 } \\
" & \text { IVheatear, } 23 \\
30 &
\end{array}
$$

Wagtail, White, 106

$$
\begin{aligned}
& \text {," White Water, } 107 \\
& \text {, } \quad \text { Yellow, } 111 \\
& \text {, } \\
& \text { Yellow Water, } 111
\end{aligned}
$$

Warbler, Aquatic, 86, 87

,, Blackcap, 57

, Chiffchaff, 69

, Dartford, 6t, 65

,, Garden, 62, 63

," Grasshopper, 88, 90

, Great Reed, 83

, Icterine, 76, 77

, Marsh, 82, 83

" Orphean, 56

, Reed, 78, 79

, Savi's, 91

, Sedge, 87,88

, Thrush, 81

" $\quad$ Villow, 72.74

, Wood, 75, 76

"Yellow-browed, 69

Water-hen, 363

Waxwing, 137, 140

Whaup, Curlew, 417

Wheatear, 23, 24, 25, 26, 27

$$
\text { " Black-throated, } 28
$$

Whimbrel, 416

Whiuchat, 28, 29, 30, 31

Whitethroat, 53, 54

Wigeon, 330

Willock, Puffin, 455

Windbibber, Kestrel, 302

IVind-hover, Kestrel, 302

Windsucker, Kestrel, 302

Woodcock, 392

Woodpecker, Great Black, 245

$$
\begin{array}{ll}
, & \text {, Spotted, } 246 \\
, & \text { Green, } 248 \\
, \quad & \text { Lesser Spotted, } 247
\end{array}
$$

Wren, 105

, Melodious Willow, it

" Willow, 73

,Yellow, 73

Wryneck, 250

$$
\text { I }
$$

Yafile, Green Woodpecker, 248 




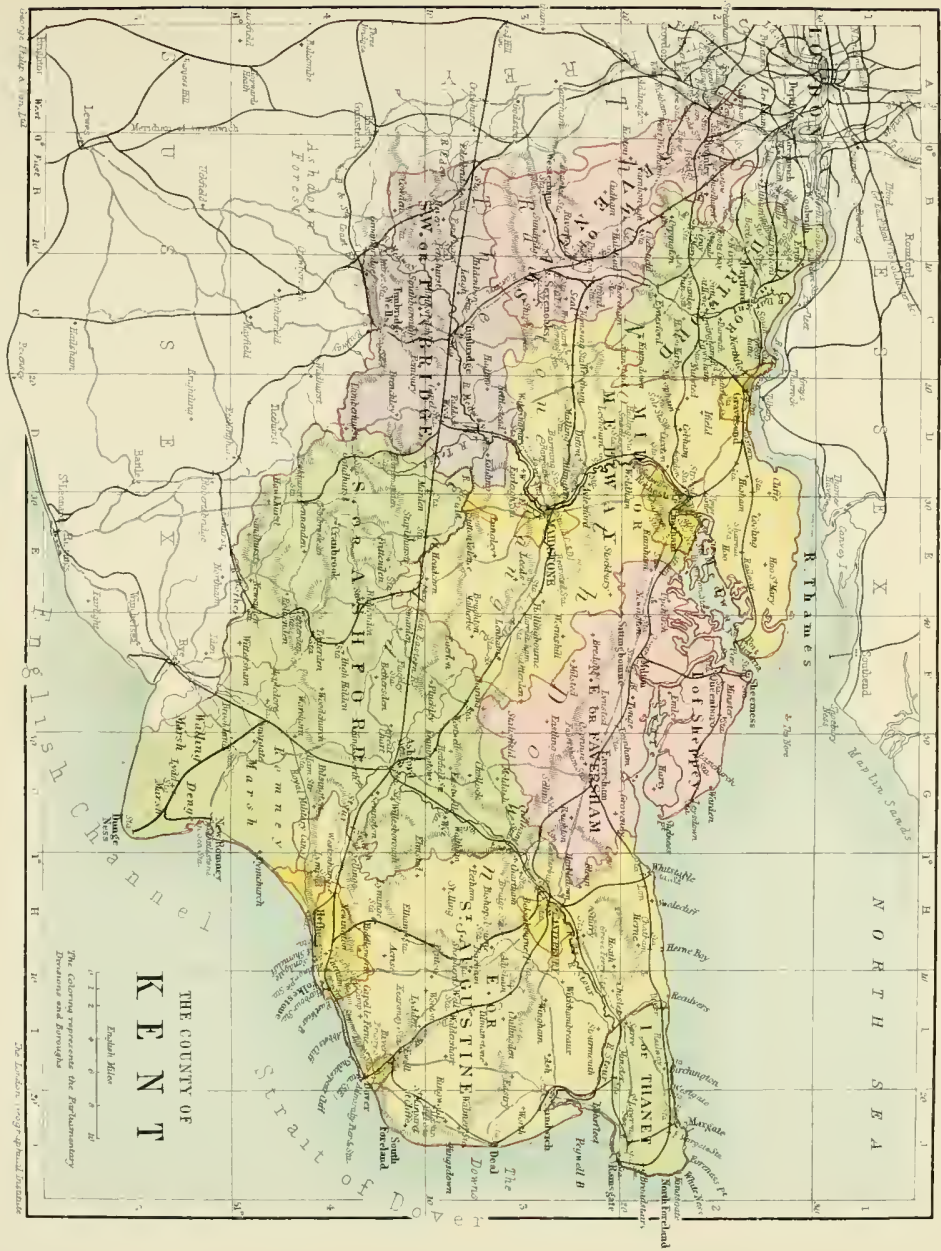







